Danilo Tavares da Silva

\title{
POLÍTICA INDUSTRIAL E DESENVOLVIMENTO \\ REGIONAL: O FOMENTO ESTATAL DOS ARRANJOS \\ PRODUTIVOS LOCAIS
}

Dissertação de Mestrado apresentada ao Departamento de Direito Econômico e Financeiro sob a orientação do Professor Associado Gilberto Bercovici.

Faculdade de Direito da Universidade de São Paulo

São Paulo, 2010 
"Uma coisa é pôr idéias arranjadas, outra é lidar com país de pessoas, de carne e sangue, de mil-e-tantas misérias." (João Guimarães Rosa, Grande Sertão:Veredas) 
À memória de meu pai, Luiz Homero. 


\section{AGRADECIMENTOS}

A elaboração desse trabalho rendeu-me frutos inesperados, cujo valor supera em muito o conhecimento que ele me proporcionou. Fui contemplado com manifestações diversas de apoio moral e intelectual, tendo podido desfrutar da gentileza, amizade e afeto de muitos.

Ao meu orientador, o prof. Gilberto Bercovici, sou muito grato não só pela paciente supervisão, mas principalmente pelo apoio a um orientando que resolveu arriscar um tema que, quando apresentado a alguns dos demais aqui agradecidos, não falhava em suscitar um "hein? O que é APL?". Ao prof. Bercovici também sou grato por poder acompanhá-lo nos cursos de Economia Política e Direito Econômico I, e por ter encontrado nele, entre uns cafés e outros, um amigo e interlocutor entusiasmado sobre a modernidade industrial, o destino do Brasil e o papel do Estado brasileiro.

Ao prof. Luis Fernando Massonetto agradeço não só as observações feitas no exame de qualificação mas também a oportunidade de acompanhá-lo nos cursos de Direito Econômico I e II. Nesses últimos dois anos tive o privilégio de cultivar uma estimada amizade que me proporciona instigantes e relevantes discussões sobre Economia Política, Direito Econômico, o S. C. Corinthians Paulista e demais assuntos da cultura universal.

Ao professor Mariano Laplane agradeço as inúmeras sugestões feitas no exame de qualificação. Todas as boas idéias que o leitor encontrar no capítulo 1 eu devo a ele.

Aos professores da pós-graduação Milton Campanário (Política Industrial) e Ricardo Abramovay (Sociologia Econômica), fica o meu agradecimento pelos cursos ministrados, fundamentais que foram para me mostrar como a ciência jurídica tem muito a avançar para dar conta das políticas contemporâneas de desenvolvimento.

Um abraço vai para o prof. Diogo Coutinho, pelas sempre certeiras dicas que me concede em nossas conversas acadêmicas, garantidas pela sua infalível solicitude; e para o prof. Floriano Peixoto de Azevedo Marques Neto, com quem tenho o privilégio de aprender (muito) enquanto trabalho. Na figura dele, que tenho como exemplo profissional, agradeço pelo apoio de todos os amigos que fiz no escritório Manesco, Ramires, Perez e Azevedo Marques. 
E muitos outros que me ajudaram com um livro emprestado e não devolvido, com a sugestão de um artigo raro com que se depararam num sítio improvável na internet, ou mesmo com uma simples conversa que, quando não ajudava a elucidar alguma questão que até então parecia muito mais intrincada do que realmente era, provava que angústias acadêmicas, quando comungadas, ficam atenuadas. Meus agradecimentos a Amanda Paulista, Caio Loureiro, Claudio Braga, Fernanda Meirelles, João Eduardo Gomide, João Manuel de Barros, Juliana Fragoso, Juliana Palma, Leandro Varison, Luana Funcia, Márcia Correa, Maria Paula Bertran, Mariana Chiesa, Mariana Macário, Marcelo Behar, Mario Schapiro, Nilce Tranjan, Paulo de Meira Lins, Silvia Naschenveng e Vitor Schiratto. Um especial agradecimento vai para Raul Borelli, Patrícia Pessoa e Tiago Tranjan, muito atenciosos desde sempre com esse trabalho e a quem muito devo também pela amizade.

Eu não poderia me dedicar à vida acadêmica se não fosse pela ajuda incondicional que minha mãe, Beatriz, tem me prestado nesses últimos 10 anos. Sem o cuidado de vó que ela devota à minha amada filha Thaiana nada disso me seria possível. À minha filhota, minha mais severa cobradora (“quantas páginas você escreveu hoje, papai?”) eu agradeço a compreensão que ela teve nos últimos meses com as nunca suficientes visitas do pai.

Agradeço, por fim, às obras de Machado de Assis, Guimarães Rosa, Anton P. Tchecov e Fiodor Dostoievski, sem as quais o tempo que despendi na escrita deste trabalho teria deixado a minha Marianna no desamparo. A ela nada agradeço porque ela teimaria em retribuir dobrado, sendo que ela já tem feito demais por mim nesses sete rápidos anos de casamento. E se não dedico a ela este trabalho é porque prefiro conceder a ela e à minha filha a dedicação de uma vida inteira.

Mesmo com tanta ajuda, certamente alguns erros e incompletudes permaneceram, mas eles são de minha inteira responsabilidade. 


\section{LISTA DE SIGLAS E ABREVIATURAS}

APEX = Agência Brasileira de Promoção das Exportações e Investimentos

APL $=$ Arrannjo Produtivo Local

APLs $=$ Arranjos Produtivos Locais

ADAM = Agência de Desenvolvimento da Amazônia

ADENE $=$ Agência de Desenvolvimento do Nordeste

BASA = Banco da Amazônia S.A

$\mathrm{BB}=$ Banco do Brasil

$\mathrm{BNB}=$ Banco do Nordeste do Brasil

BNDES = Banco Nacional de Desenvolvimento Econômico e Social

$\mathrm{CEF}=$ Caixa Econômica Federal

$\mathrm{CNPq}=$ Conselho Nacional de Desenvolvimento Científico e Tecnológico

$\mathrm{CMN}=$ Conselho Monetário Nacional

FGE=Fundo Garantidor de Exportações

FINEP=Financiadora de Estudos e Projetos

GTP-APL $=$ Grupo de Trabalho Permanente para os Arranjos Produtivos Locais

MDIC = Ministério do Desenvolvimento, Indústria e Comércio Exterior

MIN = Ministério da Integração Nacional

MPMEs = Micro, Pequenas e Médias Empresas

$\mathrm{NE}=$ Núcleos Estaduais

PDP = Plano de Desenvolvimento Preliminar

PGPM = Política de Garantia de Preços Mínimos

SEBRAE $=$ Serviço Brasileiro de Apoio às Micro e Pequenas Empresas

SUDAM = Superintendência de Desenvolvimento da Amazônia

SUDENE $=$ Superintendência de Desenvolvimento do Nordeste 


\section{RESUMO}

A presente dissertação visa descrever as políticas públicas de fomento estatal aos Arranjos Produtivos Locais (APLs) sob uma perspectiva jurídica, isto é, expondo e analisando os institutos jurídicos que são utilizados pelo poder público na tarefa de incentivar o desenvolvimento produtivo regional.

Para tanto, este trabalho discute, inicialmente, alguns conceitos elementares às teorias de política industrial, bem como os fundamentos normativos das políticas de desenvolvimento regional, somente a fim de evidenciar que o debate teórico em torno do tema dos APLs e as medidas governamentais que dele advém representam a continuidade de uma questão consagrada. Em seguida, passa-se a uma exposição de alguns aspectos jurídicos da atividade estatal de fomento (ou, na dicção constitucional, de incentivo), o que se fará tanto pela discussão de alguns temas decorrentes diretamente da Constituição da República quanto pela breve apresentação de alguns institutos jurídicos que instrumentalizam políticas de apoio ao desenvolvimento produtivo.

A partir daí, o tema dos APLs é tratado de modo mais específico: destacando-se as peculiaridades da ação pública em face da multiplicidade de agentes envolvidos na execução da política de fomento e na sua fruição; e exemplificando alguns casos em que se pôs em prática a articulação de instituições e instrumentos de incentivo.

Palavras-Chave: Política industrial, Desenvolvimento Regional, Fomento, Arranjos Produtivos Locais. 


\begin{abstract}
The present thesis intends to describe the public promotion policies of Arranjos Produtivos Locais (APLs - local production systems or clusters) under a juridical perspective. The legal instruments utilized by the government when trying to stimulate the regional productive development will be exposed and analyzed.

In order to demonstrate that the discussion concerning APLs and the government actions connected to them which are the continuity of a classical issue, this thesis discusses, initially, some elementary concepts related to industrial policy theories and the legal basis of the regional development policies. Secondly this paper shows some legal aspects of the public promotion activity, what will be done from the discussion of some subjects in the Brazilian Constitution and from a short presentation of some juridical institutes used to implement productive development policies.

Finally, the APLs subject will be analyzed in a more specific way trough distinguishing the peculiarity of public actions in the face of the multiple agents involved in the policy-making and implementing processes of public promotion policies and its fruition, and exemplifying some cases of practical articulation of promotion institutions and instruments.
\end{abstract}

Keywords: Industrial policy, Regional development, Promotion, Local Production Systems - Clusters. 


\section{SUMÁRIO}

INTRODUÇÃO.

CAPÍTUlo 1: APLS E POLÍTICA DE DESENVOLVIMENTO PRODUTIVO

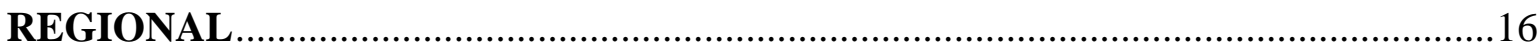

1.1 O QUE SÃo ARRanjos Produtivos LocaIs? ........................................................16

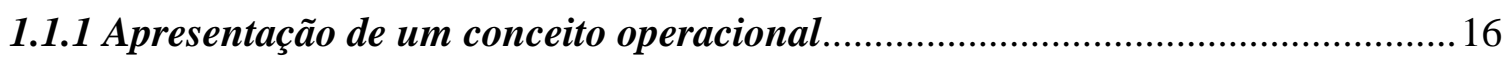

1.1.2 O conceito de APL e algumas abordagens em Economia Regional ......................21

1.2 A POLÍTICA INDUSTRIAL E O DESENVOLVIMENTO REGIONAL ........................................27

1.2.1. Condicionantes contemporâneos da política industrial ..........................................30

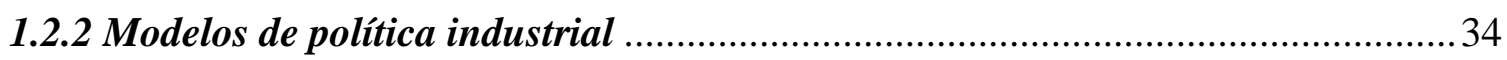

1.2.2.1 A posição liberal, as medidas de caráter horizontal e os argumentos contrários à intervenção setorial................................................................................. 37

1.2.2.2 A posição intervencionista e as medidas de caráter vertical ............................40

1.3 OS FUNDAMENTOS NORMATIVOS DO DESENVOLVIMENTO REGIONAL ...........................42

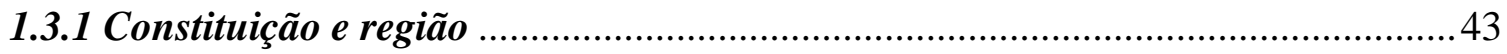

1.3.2 Outros parâmetros normativos do conceito de região no Decreto $n .^{\circ} 6.047 / 07$ (Política de Desenvolvimento Regional) ................................................................4

1.3.3 Entidades federais e o desenvolvimento produtivo regional ...................................50

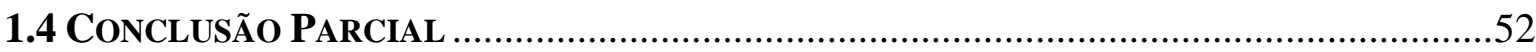

CAPÍTULO 2: A ATIVIDADE ESTATAL DE INCENTIVO (FOMENTO

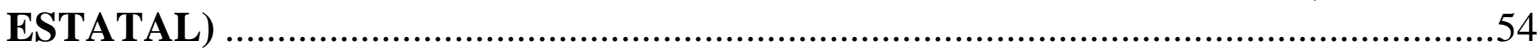

2.1 ASPECTOS GERAIS DA ATIVIDADE DE INCENTIVO (FOMENTO) ………………….........54

2.1.1 O art. 174 da Constituição da República ……………………………………........5

2.1.2 Fomento, subsidiariedade e livre iniciativa .........................................................58

2.1.3 Fomento e seleção das atividades beneficiadas ....................................................... 61

2.1.4 Fomento e exigências de contrapartidas dos beneficiados ......................................63

2.1.5 Fomento, guerra fiscal e desenvolvimento nacional ............................................64

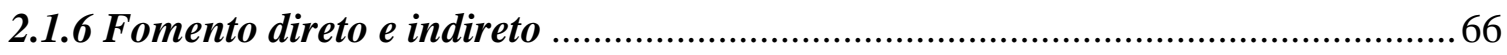

2.2 OS INSTRUMENTOS JURÍDICOS DO INCENTIVO (FOMENTO) ..........................................67

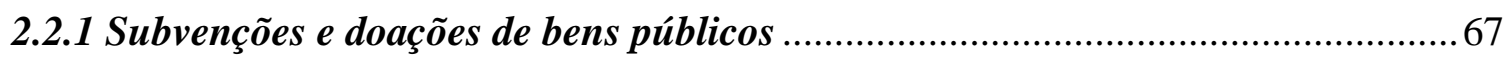

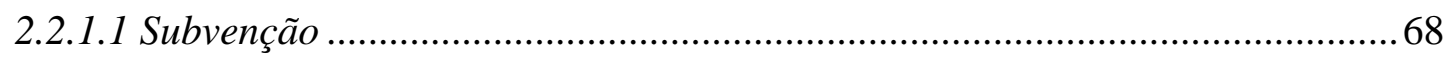

2.2.1.2 Doação e concessão de bens públicos ............................................................78

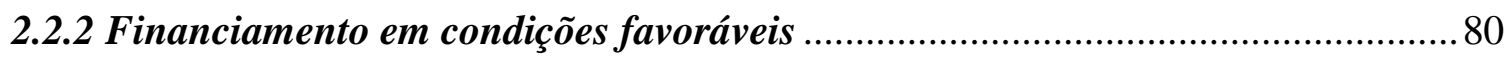

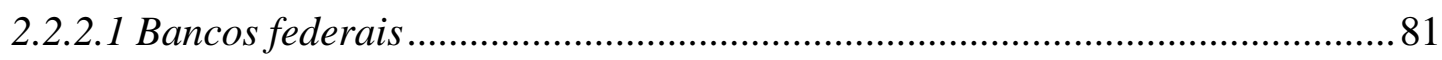


2.2.2.2 Agências estaduais de fomento

2.2.2.3 Uma propostas para financiamento de APLs a partir do modelo mexicano.. 84

2.2.3 Participação em empresa privada 85

2.2.4 Concessão de garantias creditícias..... 86

2.2.5. Desoneração tributária 90

2.2.6 Proteção tarifária e proteção comercial... 93

2.2.7 Compras governamentais .95

2.2.8 Incentivos na estrutura de preços regulados .98

2.2.9 Apoio institucional e assistência comercial 100

CAPÍTULO 3: POLÍTICAS ESPECÍFICAS DE PROMOÇÃO DOS APLs . 109

3.1 TiPOlOGIAS de CARACTERIZAÇÃo dOS APLS E CONSEQUÊNCIAS PARA PROMOÇÃo DE POLÍTICAS PÚBLICAS .

3.2 AS ESPECIFICIDADES DA PROMOÇÃO DOS APLS: FOMENTANDO AÇÕES COLETIVAS.115

3.2.1 Arranjo, cooperação e governança 115

3.2.2 Formas de atuação conjugada das entidades públicas 129

3.2.2.1 Articulação no mesmo plano federativo e em planos distintos: convênios e consorcios.

3.2.3 Formas jurídicas dos vínculos entre agentes produtivos e acesso aos instrumentos de fomento.

3.2.3.1 Contratualização 138

3.2.3.2 Criação de empresas 139

3.2.3.3 Consórcios 140

3.2.3.4 Cooperativas . 142

3.2.3.5 Associações 145

CAPÍTULO 4: ALGUNS CASOS DE PROMOÇÃO DE APLS .146

4.1 APL Pingo D’Água .146

4.2 APL COUREIRO-CALÇADISTA DO VALE DOS SINOS .148

4.3 APL de CAMPINA GRANDE

CONSIDERAÇÕES FINAIS

BIBLIOGRAFIA 


\section{INTRODUÇÃO}

A presente dissertação tem a pretensão de analisar a atuação do Estado brasileiro na promoção dos Arranjos Produtivos Locais (APLs) sob uma perspectiva jurídica. Mais especificamente, trata-se de expor os mecanismos normativos envolvidos na atuação do poder público concernentes a essa modalidade específica de política industrial e de busca do desenvolvimento regional ${ }^{1}$.

Como se pretende expor ao longo do texto, a ideia de APL tem mobilizado diversas instâncias do Estado brasileiro, de forma que políticas públicas voltadas à promoção desse modo de configuração e organização do setor produtivo já se verificam na esfera federal, estadual e municipal. A tarefa que ora se propõe, pois, é desvelar os institutos e instrumentos jurídicos envolvidos nessa forma de atuação do Estado e, nalguma medida, avaliar criticamente seus limites e possibilidades.

No Brasil, há uma vinculação histórica entre estratégias governamentais de desenvolvimento econômico, política industrial e desenvolvimento regional. Não é exagero dizer que elas se confundem ou, ao menos, já se confundiram num passado não muito distante; vide as políticas de substituição de importações surgidas nos meados dos anos 50 e suas matrizes teóricas inspiradoras (notadamente a assim chamada economia do desenvolvimento). Veja-se também um produto dessa estratégia de desenvolvimento concretizada em experiências como as da Superintendência de Desenvolvimento do Norsdeste (SUDENE), Superitendência de Desenvolvimento da Amazônia (SUDAM), Banco de Desenvolvimento da Amazônia (BASA) e do Banco do Nordeste do Brasil (BNB) e Suframa e de várias entidades estaduais norteadas pelo ideário da industrialização e da modernização do sistema produtivo local ${ }^{2}$.

Quem percorrer a história da industrialização em nosso país, principalmente na segunda metade do séc. XX, observará um processo dirigido pelo Estado, que, ao longo do tempo, valeu-se de inúmeros instrumentos jurídicos e estruturou um significativo aparato

\footnotetext{
${ }^{1}$ Wilson SUZIGAN insere os APLs como categoria subordinada aos temas da política industrial e do desenvolvimento regional em "Política Industrial e Desenvolvimento Regional". Revista Observatório da Indústria, Paraná, v. 9, p. 34-35, 2005.

2 BARROS, José Roberto Mendonça de. "A experiência regional de planejamento”, em: LAFER, Betty Mindlin. Planejamento no Brasil. 2a ed. São Paulo: Perspectiva, 1973. p. 111-137; e CANO, Wilson. Desequilíbrios regionais e concentração industrial no Brasil: 1930-1970. $3^{\text {a }}$. ed. São Paulo: UNESP, 2007.
} 
burocrático em busca do desenvolvimento industrial em regiõe nas quais o fenômeno não se deu de maneira "espontânea" (caso do Sul e Sudeste). Apesar de esse processo de forte intervenção na economia ter adquirido feições diversas ao longo do tempo, chegando mesmo a ser mitigado a partir do fim dos anos 1980, fato é que o Estado brasileiro jamais deixou de contar com instrumentos de estímulo ao setor produtivo e de persecução do desenvolvimento regional.

As políticas de promoção dos Arranjos Produtivos Locais (APLs), que surgiram e ganharam força justamente num momento de reconfiguração da atuação do Estado na economia, bem demonstram que as políticas industriais e de desenvolvimento regional persistem. Essas políticas congregam temas caros ao Direito Econômico e cumprem uma função fundamental não só para economias regionais, mas também, em alguns casos, para o setor produtivo nacional. Porém, até agora, pouca atenção despertaram na academia jurídica, não obstante as diversas discussões que o tema poderia ensejar acerca dos mecanismos normativos envolvidos nesse modo de atuação do Estado.

A sustentar a abordagem aqui proposta, citam-se três questões imediatas que autorizariam a análise do tema a partir das categorias da dogmática jurídica.

(i) Em primeiro lugar, tem-se uma óbvia subsunção do tema a uma importante questão inscrita na Constituição a respeito da busca pelo desenvolvimento econômico e redução das desigualdades regionais, e do modo pelo qual o Estado pode se articular com a iniciativa privada. A dimensão jurídica dessa discussão reside no fato de que toda e qualquer estratégia de desenvolvimento tem de se estruturar a partir de uma determinada concepção do papel do Estado e do espaço do mercado na ordem econômica constitucional. Para colocar noutros termos: o que autorizaria o Estado a imiscuir-se nas atividades privadas que dão substrato aos APLs? A função de incentivo à economia albergada no artigo 174 da Constituição confere ao poder público a devida competência de participar das aglomerações produtivas territoriais?

(ii) Ainda no plano constitucional, estão em jogo os usos possíveis da ideia de região, que hão de servir de parâmetro para a orientação das políticas de desenvolvimento regional. Caberia aqui uma discussão sobre o sentido das políticas de igualação das condições de vida e as bases territoriais em que elas deveriam se dar. Isto se liga ao tema dos APLs porque a ideia de região - ou localidade - normalmente considerada nas políticas que promovem os Arranjos diz respeito a uma área mais restrita do que aquela 
assumida na Constituição, tendo como escopo, por vezes, irradiar efeitos menos abrangentes.

(iii) Além disso, a promoção dos APLs aglutina inúmeros instrumentos de atuação econômica do Estado; assim, seu estudo põe-se como oportunidade exemplar de exposição dos mecanismos de que o poder público dispõe para concretizar suas políticas de desenvolvimento produtivo. Uma análise desse tipo permite fazer, em suma, a tradução jurídica da política industrial. Mais ainda, o fato de se perceber esse aglutinamento de diversos expedientes de política de fomento econômico obriga a explicitar quais as entidadesadministrativas voltadas ao desenvolvimento regional e o modo pelo qual elas se articulam em torno das políticas de promoção dos APLs.

Mas há, aqui, uma dificuldade: como abordar um tema cujo conteúdo consubstancia-se precipuamente na utilização, pelo Estado, de um instrumental que lhe é proporcionado pelo ordenamento jurídico, mas que não se estrutura a partir de um esquema organizatório estável e bem definido? A falta de um tratamento sistêmico dos APLs, revelado principalmente na inexistência de diplomas legislativos respeitantes ao tema, dificulta um pouco o seu estudo e impõe a formulação de uma estratégia de abordagem teórica.

Se não existe uma lei que contemple a totalidade das medidas governamentais destinadas à promoção dos APLs (e não se está defendendo a necessidade de tê-la), o que se propõe, pois, é explicitar as ferramentas jurídicas manejadas no âmbito das políticas públicas concernentes. Nessa perspectiva, busca-se, com a exposição dos institutos jurídicos aplicáveis, uma espécie de decantação conceitual da ação estatal respeitante ao tema que, em documentos oficiais, expressa-se em termos como "incentivo", "promoção", "fomento", "apoio" etc.

Esse foco nas políticas de promoção afasta uma discussão minuciosa sobre os APLs na perspectiva das teorias econômicas positivas, de modo que alguma contribuição da literatura econômica sobre política industrial e economia regional será buscada apenas de modo a evidenciar que as políticas públicas relacionadas aos sistemas locais de produção não surgem num vazio, mas, ao contrário, expressam uma concepção a respeito dos vínculos existentes entre território, produção e desenvolvimento.

Esta dissertação, portanto, não tem a ambição de se aventurar no campo da teoria econômica, mas sim de fornecer um panorama da atuação do Estado no fomento dos APLs. 
Para tanto, além dessa introdução, o texto está dividido em quatro capítulos e uma conclusão.

No primeiro capítulo se faz um exame, ainda que breve, das origens do termo “APL" e os seus significados correntes, principalmente no âmbito das políticas públicas que lhe são afetas (1.1). Além disso, busca-se expor sucintamente os contributos da literatura de Economia Industrial a fim de se expor as razões favoráveis e discordantes da adoção das políticas de desenvolvimento produtivo no atual cenário econômico, inclusive no que diz respeito aos objetivos de redução das desigualdades regionais. O intento é demonstrar os vínculos entre estratégias de desenvolvimento industrial e a questão regional (1.2); também será feita uma exposição sucinta a respeito dos fundamentos normativos das políticas de desenvolvimento regional (1.3) e, depois, uma conclusão parcial (1.4).

O segundo capítulo busca expor alguns dos instrumentos de fomento econômico, os mecanismos jurídicos pelos quais se concretiza a atividade que o caput do art. 174 da Constituição denomina de incentivo. Isso será feito mediante a discussão de alguns aspectos conceituais da ideia de fomento (2.1) seguida de uma apresentação dos traços essenciais dos institutos jurídicos que dão concreção à ação fomentadora, mencionando-se algumas possibilidades de aplicação no âmbito das políticas de promoção dos APLs (2.2), arrematando-se o capítulo com uma breve conclusão (2.3).

No terceiro capítulo, serão tratadas algumas questões específicas da promoção dos APLs. Inicialmente será exposta uma tipologia de APLs para demonstrar que, na verdade, sob tal designação reúnem-se configurações diversas de aglomeração produtiva, de modo que a variedade das situações fáticas enseja diferentes estratégias de atuação estatal (3.1). Em seguida, serão discutidas questões específicas a respeito dos mecanismos de cooperação e governança, as possibilidades de articulação das entidades governamentais, bem como as formas jurídicas que os agentes privados podem assumir tendo em vista a fruição de medidas de fomento coletivo (3.2).

Já o capítulo quarto dará notícia de alguns casos que podem ser tomados como exemplo de aplicação das políticas de promoção dos APLs: o APL Pingo D’Água (4.1), o APL do Vale dos Sinos (4.2) e o APL de Campina Grande (4.3).

As considerações finais servirão para, a partir do que foi tratado ao longo da dissertação, discutir algumas questões a respeito dos sentidos possíveis que as políticas de 
promoção dos APLs têm assumido e podem vir a assumir como política de desenvolvimento produtivo regional.

No mais, vale fazer uma observação cujo caráter pessoal e algo subjetivo impede que tenha o estatuto de uma nota metodológica: a ênfase que dezenas de entidades municipais, estaduais e federais dão ao tema dos APLs como política pública - no plano midiático, isso é, no que respeita à divulgação das ações das entidades públicas - nem de longe é acompanhada da efetividade da ação estatal ou, ao menos, da possibilidade de conhecimento e acesso dos dados que reflitam tal ação. Os APLs estão nas pautas dos poderes públicos, mas não resultam necessariamente em ações concretas duradouras nem tampouco são acompanhadas de uma mínima estrutura institucional estabilizada capaz de fornecer memória à ação pública. As políticas de promoção dos APLs, muitas vezes, resumem-se à boa vontade do gestor público de ocasião, de forma que, com a substituição deste, perde-se ou a política pública ou, senão, a possibilidade de avaliá-la em sua evolução temporal.

Essas observações, bem verdade, calhariam à guisa de conclusão, mas ocorre que ela tem implicações no conteúdo do trabalho, o qual foi ensejado justamente pela grande divulgação do que se delineava uma política pública promissora - tanto no que diz respeito às ações programadas quanto nos resultados potenciais. Contudo, a presente pesquisa encontrou séria dificuldade quando se tratou de obter de entidades públicas o mínimo de informações e dados sobre o assunto em questão. Mesmo a simples troca de impressões ou acesso a dados provisórios ou não oficiais foi dificultosa. Resultado disso é que não se mostrou viável realizar uma análise mais robusta da eficácia das políticas de fomento aos APLs, de sorte que a fonte principal de concretização das ações estatais se fez de maneira indireta, isso é, por meio de estudos de casos anteriorente publicados.

De todo modo, essas dificuldades serviram para demonstrar, ao menos um pouco, que a tarefa de estimular o desenvolvimento da produção, mesmo em situações em que a atividade produtiva é marcada pelo aspecto rudimentar, não é nada simples. Muito pelo contrário, superar a condição periférica (e mesmo a condição periférica no interior da periferia do capitalismo) é tarefa das mais complexas. 


\section{CAPÍTULO 1}

\section{APLS E POLÍTICA DE DESENVOLVIMENTO PRODUTIVO REGIONAL}

\subsection{O QUe SÃo Arranjos Produtivos Locais?}

A ausência de estudos sobre APLs na academia jurídica obriga a que se gaste algumas palavras a título de apresentação do tema. Na verdade, a necessidade de esclarecer com maior precisão o significado do termo "APL" não se deve apenas ao fato de o assunto ser pouco frequentado no âmbito do estudo do Direito, mas também à maneira específica como o tema das aglomerações produtivas tem sido tratado no Brasil, principalmente no que toca à promoção de políticas públicas.

\subsubsection{Apresentação de um conceito operacional}

Sob certa identidade no enfoque de aglomerações produtivas, fenômenos que por vezes guardam algumas diferenças importantes podem receber a mesma designação, motivo pelo qual, no Brasil, ainda se debate a imprecisão terminológica relativa às aglomerações produtivas dotadas de alguma coordenação. Em revisão de literatura sobre a evolução das configurações produtivas locais no Brasil, Lia HASENCLEVER e Isleide ZISSIMOS encontram as seguintes designações: distritos industriais, clusters, sistemas produtivos localizados, complexos industriais ou de industrialização descentralizada, arranjos produtivos e inovativos locais e configurações produtivas locais - segundo as autoras, todos esses termos "procuram traduzir formas de concentração de empresas $e$ instituições num território e a natureza de suas atividades, bem como o grau de interação entre os agentes" ${ }^{3}$.

\footnotetext{
${ }^{3}$ As autoras enfatizam as dificuldades que decorrem das variedades de termos: "Eles foram adotados de acordo com as diferentes propostas analíticas dos vários pesquisadores a partir de estudos de outras realidades que não a brasileira. Neste sentido, vários destes termos podem evocar a priori realidades históricas completamente distintas. Além disso, é importante observar que esta miríade de termos causa confusão por dois motivos: (i) o mesmo objeto pode ser designado por diferentes termos. Por exemplo, a
} 
A difusão do termo APL no Brasil se deu principalmente pelo trabalho do Serviço Brasileiro de Apoio às Micro e Pequenas Empresas (SEBRAE) em conjunto com os pesquisadores que compõem a Redesist ${ }^{4}$. Essa preocupação com a promoção das estruturas empresariais de menor porte foi decisiva na consolidação de um padrão de estudos sobre APLs, podendo mesmo ter contribuído para que houvesse uma forte vinculação entre o tema e a promoção de políticas de fomento às micro e pequenas empresas ${ }^{5}$. De toda sorte, os referenciais metodológicos tomados pelos programas oficiais não excluem empresas de maior porte. Já para José E. CASSIOLATTO \& Helena M. LASTRES:

Arranjos produtivos locais são aglomerações territoriais de agentes econômicos, políticos e sociais - com foco em um conjunto específico de atividades econômicas - que apresentam vínculos mesmo que incipientes. Geralmente, envolvem a participação e a interação de empresas - que podem ser desde produtoras de bens e serviços finais até fornecedoras de insumos e equipamentos, prestadoras de consultoria e serviços, comercializadoras e clientes, entre outros - e suas variadas formas de representação e associação. Incluem também diversas outras instituições públicas e privadas

região do Vale dos Sinos (RS) é denominada ao mesmo tempo de arranjo produtivo local (Cassiolato e Lastres, 2003) e cluster (Schmitz, 1995); e (ii) diferentes termos são usados como sinônimos. Por exemplo, Crocco el al. (2003) utilizam tanto sistema produtivo local como cluster para designar a mesma concentração territorial de empresas" emn HASENCLEVER, L. \& ISSIMOS, I. "A Evolução das Configurações Produtivas Locais no Brasil:Uma Revisão da Literatura”. Revista de Estudos Econômicos, v. 36, p. 410, 2006.

4 A Rede de Pesquisa em Sistemas Produtivos e Inovativos Locais - RedeSist, sediada no Instituto de Economia da Universidade Federal do Rio de Janeiro, foi talvez a primeira equipe de pesquisadores que se voltou ao estudo sistemático dos APLs, seu primeiro projeto de pesquisa, e contribuiu para a difusão da designação.

5 Exemplo significativo disso é que, no Plano Plurianual 2003-2007 e no 2008-2011, o tema está contemplado no programa 0419 - Desenvolvimento de Micro, Pequenas e Médias Empresas (MPMEs) do Ministério de Desenvolvimento, Indústria e Comércio (MDIC). As ações albergadas na rubrica desse programa são de competência do Departamento de Micro, Pequenas e Médias Empresas da Secretaria do Desenvolvimento da Produção, órgão esse também responsável pela Secretaria Executiva do Grupo de Trabalho Permanente para Arranjos Produtivos Locais (GTP APL). Outro indício disso é o fato de que grande parte das ações no plano federal estão concentradas no SEBRAE, que tem como missão precípua o apoio ao pequeno empreendedor. HASENCLEVER \& ZISSIMOS explicam esse enfoque em pequenas e médias empresas a partir (i) das afinidades dessas estruturas empresariais com o modelo flexível (pósfordista) de produção e (ii) dos imperativos de sobrevivência mercadológica. Veja-se: “No Brasil, há uma tendência de se enfatizar as pequenas e médias empresas (PMEs). O argumento é que estas teriam vantagens sobre as grandes empresas quando localizadas proximamente por poderem responder mais rapidamente às mudanças ambientais repentinas. O fato de as PMEs estarem localizadas proximamente permitiria que elas se apropriassem das economias externas geradas pela complementariedade e facilidade de transações entre fábricas e o aumento da divisão do trabalho, resultantes das ventagens do contato direto, troca de informações, articulações estratégicas, fluxo de mercadoras e trabalho. Estas economias externas e a maior flexibilidade das PMEs juntas seriam capazes de compensar com vantagens as grandes empresas verticalizadas do padrão de produção fordista. No entanto, deve-se considerar que embora algumas configurações brasileiras sejam relativamente desenvolvidas, muitas ainda estão próximas das chamadas “aglomerações de sobrevivência”. (Altenburg e Meyer-Stamer, 1999). As empresas nestas configurações são justamente as de menor porte, têm características informais e produzem bens e serviços de baixa qualidade para mercados locais. Os graus de especialização e de cooperação também são baixos, assim como os salários pagos aos trabalhadores.” em HASENCLEVER, Lia \& ISSIMOS, Isleide. op. cit., p. 412. 
voltadas para a formação de capacitação de recursos humanos (como escolas técnicas e universidades); pesquisa, desenvolvimento e engenharia; política promoção e financiamento ${ }^{6}$.

O conceito acima expresso de APL, apesar de não ser adotado de maneira consensual $^{7}$, parece ser suficientemente amplo para abarcar as diversas situações de aglomeração produtiva dotadas de algum vínculo de cooperação e coordenação que recebem apoio de diversas instâncias governamentais, e é nele que essa dissertação se baseará. A questão taxonômica aqui importa menos do que o estudo da racionalidade das políticas públicas nessa matéria. Prova disso é que não se tem um conceito de APL de absoluto consenso, mas nem por isso deixa de haver inúmeras iniciativas que se valem do termo para enunciar uma política pública de desenvolvimento produtivo regional.

De todo modo, o conceito aqui expresso parece ser o que melhor descreve as configurações produtivas locais em relação às quais se tem verificado o fomento estatal. Observa-se que os conceitos de APL tomados como referência pelas entidades governamentais não apresentam estrita identidade; todavia, nenhum deles parece destoar fundamentalmente da noção que ora se propõe utilizar. No Manual de Apoio aos Arranjos

\footnotetext{
${ }^{6}$ Segundo os citados autores, principais responsáveis pela difusão do termo APL no Brasil por meio do trabalho que coordeanaram na RedeSist, o termo que traduziria melhor a aglomeração produtiva dotada de maior grau de organização, articulação e dinamismo seria "Sistema Produtivo e Inovativo Local" (SIPL). Veja-se: "Sistemas produtivos e inovativos locais são aqueles arranjos produtivos em que a interdependência, articulação e vínculos consistentes resultam em capacidade inovativa endógena, da competitividade e do desenvolvimento local. Assim, consideramos que a dimensão institucional e regional constitui elemento crucial do processo de capacitação produtiva e inovativa. Diferentes contextos, sistemas cognitivos e regulatórios e formas de articulação e aprendizado interativo entre agentes são reconhecidos como fundamentais na geração e difusão de conhecimento e particularmente aqueles tácitos. Tais sistemas podem ser tanto formais quanto informais". O conceito de APL serviria para nomear apenas as situações de articulação rudimentar entre agentes econômicos.

7 Todavia, para demonstrar que o conceito eleito não foge de um certo padrão presente na realidade estudada, apresenta-se (apresentamos é melhor nessa oração)outras propostas de definição de termos correlatos. Vejase o que é proposto por Wilson SUZIGAN: "Neste trabalho, refere-se a APLs como um sistema localizado de agentes econômicos, políticos e sociais ligados a um mesmo setor ou atividade econômica, que possuem vínculos produtivos e institucionais entre si, de modo a proporcionar aos produtores um conjunto de benefícios relacionados com a aglomeração das empresas. Configura-se um sistema complexo em que operam diversos subsistemas de produção, logística e distribuição, comercialização, desenvolvimento tecnológico (P\&D, laboratórios de pesquisa, centros de prestação de serviços tecnológicos) e onde os fatores econômicos, sociais e institucionais estão fortemente entrelaçados". O autor, entretanto (só para evitar a repetição), esclarece que o conceito mais adequado para expressar o fenômeno em questão é o de Sistema Local de Produção, que ele mesmo utiliza em outros trabalhos; todavia, diante do uso difundido do termo APL, passa-se (passaremos é melhor) a usá-lo. Para Maria Tereza Leme Fleury, "os sistemas locais de produção ou arranjos produtivos locais (APLs) ou, para nós, clusters, são uma aglomeração de tamanho considerável de empresas (em geral pequenas e médias) em área espacialmente delimitada, com um claro perfil de especialização, na qual o comércio e a integração entre firmas são substanciais." FLEURY, Afonso \& FLEURY. Maria Tereza Leme. "Por uma Política Industrial Desenhada a Partir do Tecido Industrial”, em FLEURY, Maria Tereza Leme \& FLEURY, Afonso (org.). Política Industrial 1, São Paulo, PubliFolha/FEA-USP, 2004, p. 86
} 
Produtivos Locais ${ }^{8}$, editado pelo Grupo de Trabalho Permanente para APLs do Governo Federal $^{9}$, lê-se a seguinte definição:

O Arranjo Produtivo Local pode ser descrito como um grande complexo produtivo, geograficamente definido, caracterizado por um grande número de firmas envolvidas nos diversos estágios produtivos e, de várias maneiras, na fabricação de um produto, onde a coordenação das diferentes fases e o controle da regularidade de seu funcionamento são submetidos ao jogo do mercado e a um sistema de sanções sociais aplicado pela comunidade (Becattini, 1999). A contigüidade espacial permite ao sistema territorial de firmas viabilizar externalidades produtivas e tecnológicas sem perder sua flexibilidade e adaptabilidade.

Já o Sebrae trabalha com a noção de que "Arranjos Produtivos Locais são aglomerações de empresas localizadas em um mesmo território, que apresentam especialização produtiva e mantêm vínculos de articulação, interação, cooperação e aprendizagem entre si e com outros atores locais, tais como: governo, associações empresariais, instituições de crédito, ensino e pesquisa"10.

Parte da generalidade do conceito de APL se deve ao fato de que ele tem de dar conta de vários aspectos de uma realidade multifacetada. Além disso, a ideia de APL parece se prestar, sobretudo, à função de embasar a ampliação da atuação do Estado no fomento a determinadas atividades produtivas, quando presentes algumas razões que autorizem e justifiquem o incentivo do poder público ${ }^{11}$. Nesse sentido, trabalhar com um conceito muito restrito de um fenômeno que enseja uma política pública não tem muito

\footnotetext{
${ }^{8}$ Brasília: MDIC, 2004.

${ }^{9}$ O Grupo de Trabalho Permanente para Arranjos Produtivos Locais (GTP APL) foi instituído pela Portaria Interministerial $n^{\circ} 200$ de 03/08/04, reeditada em 24/10/2005 e 31/10/2006, e é composto atualmente por 33 instituições governamentais e não governamentais, entre as quais 12 Ministérios, sob a coordenação do MDIC.

${ }^{10}$ SEBRAE, Metodologia para APLS. É interessante observar como na Metodologia para APLs do Sebrae, as preocupações de ordem teórica concernentes à classificação das aglomerações produtivas são sobrepostas pela evidência de que, para fins de política pública, elas pouco importam: "Tanto nos APL como nos distritos industriais, a ênfase é colocada no fato de que grande parte da produção e do emprego é gerada por empresas de pequeno e médio portes. Esses sistemas locais de produção caracterizam-se, ainda, pela flexibilidade de suas estruturas produtivas, quando comparadas àquelas do modelo fordista tradicional. Em particular, em ambos os modelos, à cooperação elou competição intrafirmas, vem juntar-se a formação de uma comunidade sociocultural (co-action) nos distritos industriais, de acordo com os termos de Sforzi (1992), que participa ativamente da construção do conhecimento/produção. Em síntese, podemos dizer que cada uma dessas definições enfatiza determinados aspectos do sistema produtivo. Porém, no que concerne às recomendações de política econômica, essas diferenças não são, a nosso entender, significativas".

11 Isso não significa, todavia, que não se faz necessário uma metodologia minimamente sólida de identificação e caracterização dos APLs, sob pena de se autorizar políticas de fomento industrial sem o menor critério. A esse tema se voltaremos no capítulo 03.
} 
sentido quando o propósito da ação estatal é explorar ao máximo as potencialidades de desenvolvimento regionalpresentes nalgumas aglomerações produtivas.

Todavia, cabe, desde já, uma tentativa de esclarecimento. A noção de APL envolve certas delimitações fundamentais e necessárias à sua caracterização, de modo que, detalhando-as, pode-se chegar a uma definição mais precisa do conceito. Aqui, serão ressaltados aspectos referentes (i) à territorialidade; (ii) aos agentes envolvidos; (iii) aos vínculos entre os agentes e (iv) à importância do desenvolvimento das atividades econômicas que dão substrato ao arranjo ${ }^{12}$.

(i) Em primeiro lugar, um APL se dá num determinado território; obviamente que todo e qualquer processo econômico se baseia num determinado espaço, mas aqui se trabalha com um conceito de espacialidade e mesmo de regionalidade algo restrito; a escala espacial envolvida num APL é de pequena dimensão, dá-se no território de um único município ou, no máximo, no âmbito de municípios circunvizinhos.

(ii) Os agentes aqui referidos não são somente as empresas envolvidas no processo econômico - as quais podem ser desde produtoras de bens e serviços finais até fornecedoras de insumos e equipamentos, prestadoras de consultoria e serviços, comercializadoras e clientes. Um APL também pode se compor de entidades de classe privadas, bem como por instituições públicas diversas (serviços sociais de fomento à atividade produtiva, escolas técnicas, universidades, bancos de fomento).

(iii) No que se refere aos vínculos entre os agentes, trata-se de ressaltar como a aglomeração produtiva se perfaz em algo concertado, arranjado, o que remete às ideias de articulação, coordenação e até mesmo de capital social. Num APL, os agentes operam em algum grau de cooperação, ainda que estejam em situação de competição por mercado (caso de diferentes empresas que produzem o mesmo tipo de mercadoria) ou que suscitem contraposição de interesses (caso da relação compradores e fornecedores,em que o APL se estrutura como cadeia produtiva). Relações mutualistas, contudo, não são menos frequentes, incidindo principalmente nos fenômenos cooperativistase associativistas, e nas situações em que o Estado figura como fomentador.

(iv) Por último, deve-se considerar os objetivos visados com o incentivo às atividades produtivas que dão substrato ao arranjo. A promoção dos APLs se legitima, do

\footnotetext{
${ }^{12}$ Essa análise será retomada no capitulo 03. Por ora, a intenção dessa exposição é simplesmente vincar o conteúdo do conceito de APL.
} 
ponto de vista da aplicação das políticas públicas, porque induz determinados agentes e regiões a alcançarem um novo patamar, fazendo com que a atividade produtiva irradie os efeitos diversos que se espera do desenvolvimento econômico: aumento da renda dos agentes envolvidos, geração de empregos, melhoria da infra-estrutura, das relações trabalhistas, das atividades de P\&D, formação e consolidação de mercados, desenvolvimento de novos produtos, aumento de arrecadação tributária, ampliação da pauta e do volume de exportação etc. Enfim, o desenvolvimento da produção conformada em determinado arranjo tem o sentido da busca pelo desenvolvimento econômico. Não se trata de simples privilégio carente de justificativas robustas relacionadas ao desenvolvimento setorial e econômico.

O esforço de esclarecimento conceitual acima esboçado fornece, na verdade, razões para a amplitude do conceito. A fórmula "APL" e o amplo conteúdo de situações que abarca mostram-se muito úteis para expressar uma conjunção de diversos fenômenos e estratégias de desenvolvimento estudados e sugeridos por algumas correntes teóricas de Economia Regional. Justamente o exame dessas correntes teóricas, ainda que resumido, fornece uma primeira abordagem ao nosso tema. Entender como essa tradição de pensamento está incorporada à ideia de Arranjo Produtivo Local pode revelar a serventia do conceito e a razão pela qual ele se firmou e, hoje, é tido como referencial de política pública.

\subsubsection{O conceito de APL e algumas abordagens em Economia Regional}

A dimensão regional dos processos produtivos deu ensejo a inúmeros estudos sobre as conexões entre território e economia. Da análise dos distritos industriais feita por Alfred Marshall no final do séc. XIX e das teorias da localização, passando pelos trabalhos de Perroux, Myrdal e Hirschman, e chegando às mais recentes abordagens neoschumpeterianas sobre sistemas locais de produção baseadas na capacidade de inovação, verifica-se uma análise cada vez mais abrangente sobre as aglomerações produtivas.

Desse imenso corpo teórico relativo às conexões entre economia e território é possível destacar, seguindo a análise sugerida por Wilson SUZIGAN, algumas das principais linhas de estudo que vinculam o elemento geográfico à formação de 
aglomerações industriais ${ }^{13}$. Apenas para ilustrar como essa discussão pode se vincular mais estreitamente à questão das aglomerações industriais, expomos a categorização formulada por Wilson SUZIGAN. Esse autor enumera as seguintes abordagens: (i) a Nova Geografia Econômica, da qual Paul Krugman é o maior expoente; (ii) a Economia das Empresas, na qual os trabalhos de Michael Porter são de maior repercussão; (iii) a Economia regional sobre clusters; (iv) a Economia da Inovação e (v) a abordagem focalizada nas pequenas empresas e distritos industriais, na qual os estudos de H. Schmitz são fundamentais, principalmente no estudo de casos no Brasil.

Um ponto em comum reside em que todas as abordagens do fenômeno agomerativo têm de lidar com o conceito de economias externas, ideia essa que adveio da análise de Alfred Marshall sobre os distritos industriais ingleses. Segundo esse autor, haveria ganhos na organização e no desenvolvimento técnico resultantes da maior integração dos agentes envolvidos no processo produtivo local ${ }^{14}$, além da criação de escala que viabilizasse atividades das indústrias "subsidiárias" e da formação de um mercado constante de mãode-obra especializada.

Embora não se possa traçar uma linha de influência direta entre Marshall e os grandes nomes da Economia do Desenvolvimento, a concentração industrial e seus efeitos foram foco da atenção de F. PERROUX, G. MYRDAL e A. HIRSCHMAN. Como explica Danilo IGLIORI ao tratar das obras dos dois primeiros, elas "focalizam a importância da concentração espacial da atividade produtiva para a ocorrência do crescimento econômico, examinando particularmente o papel das economias externas que são geradas localmente" . A obra do schumpeteriano Perroux a respeito da questão regional não se

\footnotetext{
${ }^{13}$ Para um bom resumo sobre a tradição teórica em Economia Regional, vide CAVALCANTE, Luiz R. M. T. "Produção Teórica em Economia Regional:Uma Proposta de Sistematização". Revista Brasileira de Estudos Regionais e Urbanos, v. 02, p. 9-32, 2008. Para um apanhado bastante amplo sobre vertentes teóricas contemporâneas, ver BRANDÃO, Carlos. Território \& Desenvolvimento: As Múltiplas Escalas entre o Local e o Global. Campinas, Editora Unicamp, 2007, p. 35.

14 "São tais as vantagens que as pessoas que seguem uma mesma profissão especializada obtêm de uma vizinhança próxima, que desde que uma indústria escolha uma localidade para se fixar, aí permanece por longo espaço de tempo. Os segredos da profissão deixam de ser segredos, e, por assim dizer, ficam soltos no ar, de modo que as crianças, absorvem inconscientemente grande número deles. Aprecia-se devidamente um trabalho bem feito, discutem-se imediatamente os méritos de inventos e melhorias na maquinaria, nos métodos e na organização geral da empresa. Se um lança uma idéia nova, ele é imediatamente adotada pelos outros, que a combinam com sugestões próprias, e, assim essa idéia se torna uma fonte de idéias novas. Acabam por surgir, nas proximidades desse local, atividades subsidiárias que fornecem à indústria principal instrumentos e matérias-primas, organizam seu comércio e, por muitos meios, lhe proporciona, economia de material." Princípios de Economia: Tratado Introdutório. São Paulo: Abril Cultural, 1982, p. 320-321.

15 Economia dos Clusters Industriais e Desenvolvimento. São Paulo: Iglu Editora, p. 94.
} 
baseia em modelos de equilíbrio geral, mas assume como pressuposto uma relação de desigualdade entre firmas, regiões e países ${ }^{16}$. Em seu conhecido "Notas sobre os Pólos de Desenvolvimento", Perroux está preocupado em explicar as razões pelas quais o crescimento econômico não se dá de forma homogênea pelo espaço nacional. Como sintetiza Gilberto BERCOVICI, chamando a atenção para a importância do pólo para o crescimento regional e da totalidade da economia:

De acordo com a teoria de Perroux, a aparição de uma indústria nova ou crescimento de uma indústria existente se difunde, o que faz com que, ao longo de grandes períodos, sejam espalhadas transformações que facilitam o surgimento de novas indústrias e a continuidade na difusão de inovações. No entanto, o crescimento não ocorre em todos os lugares, mas em pólos de desenvolvimento, com intensidades variáveis, de onde expande seus efeitos para o resto da economia.. Em um pólo industrial complexo, aglomerado geograficamente e em crescimento, intensificam-se as atividades econômicas, que geram também disparidades regionais. $\mathrm{O}$ pólo de desenvolvimento modifica seu ambiente geográfico imediato e, se é poderoso, toda a estrutura da economia nacional que a integra. O crescimento do mercado no espaço, quando se origina da comunicação de pólos de crescimento territorialmente aglomerado, não é um crescimento igualmente repartido, pois opera por meio da concentração de meios e pontos de crescimento de onde se irradiam as mudanças. Uma economia nacional em crescimento é fruto da combinação de elementos relativamente ativos (indústrias-motrizes, pólos industriais e atividades geograficamente aglomeradas) e elementos relativamente passivos (indústrias decadentes e regiões dependentes de pólos geograficamente aglomerados), com os primeiros induzindo os segundos ao crescimento $^{17}$.

Gunnar MYRDAL, em sentido semelhante no que respeita à produção de efeitos externos, vale-se da ideia de causação circular para explicar como os processos sociais se compõem de forma encadeada. Os resultados dos processos sociais (inclusive no plano econômico) se originam em causas que se sobrepõem em sentido virtuoso ou vicioso. Transpondo esse tipo de análise para a dimensão econômica nacional, os efeitos da decisão econômica, face às demais regiões, podem ser regressivos (backwash effects - ex: êxodo de trabalhadores qualificados das regiões pobres para as regiões ricas, acentuando os

\footnotetext{
16 "A amarga verdade é esta: o crescimento não aparece em toda parte ao mesmo tempo; manifesta-se em pontos ou pólos de crescimento, com intensidade variável; difunde-se por meio de diferentes canais, com distintos efeitos terminais sobre o conjunto da economia". PERRROUX, F. "A Planificação e os Pólos de Desenvolvimento", em Notas sobre o Conceito de Pólo de Crescimento apud Economia dos Clusters Industriais e Desenvolvimento. $1^{\text {a }}$ ed. São Paulo: Iglu Editora, p. 94.

${ }^{17}$ Desigualdades Regionais, Estado e Constituição. São Paulo: Max Limonad, 2003, p. 65
} 
problemas relacionados à mão-de-obra no local e as diferenças regionais) ou propulsores (spread effects - ex: instalação de uma planta industrial que induz à formação de uma cadeia de fornecedores em regiões próximas). Como explica Gilberto BERCOVICI, chamando a atenção para as implicações de políticas públicas advindas da teoria, " $O$ conhecimento destes efeitos possibilita a identificação dos fatores que aumentam ou reduzem a capacidade de irradiação, possibilitando o planejamento, elaborado pelo Estado para a orientação do desenvolvimento econômico" ${ }^{\text {18 }}$.

Albert HIRSCHMAN, por sua vez, trata das cadeias de reação oriundas da realização de investimentos: os efeitos de arrasto (backward linkage) e os efeitos de propulsão (forward linkage). Esses efeitos, em síntese, traduzem as repercussões da atividade produtiva a montante e a jusante, eis que ela ao mesmo tempo gera demanda por insumos e dá origem a produtos que podem vir a se transformar eles mesmos em insumos para novas atividades que se situem numa etapa posterior da cadeia produtiva. Tais efeitos seriam, portanto, a manifestação de uma cadeia de desequilíbrios que geram as economias externas ${ }^{19}$.

Essa tradição teórica da Economia do Desenvolvimento tem afinidades com importantes marcos teóricos constituídos no Brasil também na década de 1950 e com a estratégia de industrialização do país. É de se destacar aqui a obra de Celso FURTADO e a influência que ela teve na criação da SUDENE. O Relatório do Grupo de Trabalho para o Desenvolvimento do Nordeste, coordenado por Celso FURTADO, apregoava a industrialização como o instrumento de desenvolvimento da região e praticamente estabeleceu as bases de atuação das políticas regionais de desenvolvimento produtivo ${ }^{20}$.

A tradição marshalliana e a preocupação com o entendimento do fenômeno da aglomeração industrial e desenvolvimento econômico foram retomadas também por diversos autores que estudaram o caso da Terceira Itália e de outras regiões da Europa nos anos 70 e 80, para se constatar que uma das principais causas do êxito econômico de pequenas e médias empresas se devia a fatores ligados à cooperação e coordenação das firmas aglomeradas. Desde então, é crescente o foco em pesquisas a respeito da ação deliberada de agentes na criação das eficiências externas, o que foi negligenciado pelas

\footnotetext{
${ }^{18}$ In Desigualdades Regionais, Estado e Constituição. São Paulo, op. cit, , p. 65-66.

${ }^{19}$ Ver Desigualdades Regionais, Estado e Constituição. São Paulo, op. cit, , p. 65-66

20 A respeito do trabalho de Celso FURTADO e sua influência na estruturação da SUDENE, ver BERCOVICI. G. Desigualdades Regionais, Estado e Constituição. op. cit, especialmente o capítulo 03: "Os fundamentos da política brasileira de desenvolvimento regional”; p. 83-144.
} 
teorias clássicas da localização. Assim é que se constituiu uma nova abordagem das aglomerações industriais em países em desenvolvimento, a qual possui algumas diferenças em relação àquela empregada pelos teóricos da Economia do Desenvolvimento: não se enfatiza a aptidão das aglomerações para desencadear processos que se espraiem para outras partes da economia nacional, de modo que o enfoque é precipuamente regional; centra-se a atenção nas perspectivas do aumento da competitividade de pequenas e médias empresas e se confere grande importância aos vínculos de cooperação entre as empresas como meio de redução de custos e geração de fluxos de inovação ${ }^{21}$.

Nessa linha é que se destaca o trabalho de Hubert SCHMITZ e seu conceito de eficiência coletiva. A importância desta noção nos estudos sobre APL justifica a longa citação de Wilson SUZIGAN, que bem a sintetiza e elucida as linhas teóricas por ele citadas ("i" a "v" supra):

O essencial da distinção entre os dois grupos [de abordagem das aglomerações] pode ser sumariado pela comparação de três pares de categorias analíticas: economias externas de natureza incidental versus deliberada; a caracterização de economias externas como capacitantes (enabling) versus incapacitantes (disabling), e processos de mão invisível versus apoio do setor público no desempenho e na dinâmica das aglomerações. Na última abordagem, na qual se destacam as contribuições de H. Schmitz (1997; 1999), é introduzido um conceito síntese bastante útil: o da eficiência coletiva. Esse conceito resume, de certa forma, a referida comparação entre categorias analíticas, e pode servir de base para estudos de casos de aglomerações. Por isso é apresentado com algum detalhe a seguir.

O conceito de eficiência coletiva parte do reconhecimento da importância de economias externas locais puras (Marshallianas), mas argumenta que tais economias externas não são suficientes para explicar o crescimento e a competitividade das empresas nos clusters. Um segundo e talvez mais importante fator é a ação deliberada, tanto das empresas no sentido da cooperação (entre as próprias empresas e com agentes comerciais e de marketing, associações empresariais, sindicatos, centros de pesquisa tecnológica e de design, e outros), como do setor público na implementação de políticas. $O$ conceito de eficiência coletiva combina os dois efeitos, i. e., das economias externas locais espontâneas ou não planejadas e das ações conjuntas deliberadas ou planejadas das empresas e do setor público,

${ }^{21}$ Esses três caracteres na nova abordagem são apontados por Danilo IGLORI em Economia dos Clusters Industriais e Desenvolvimento. op. cit, p. 98. 


\section{para explicar as vantagens competitivas de empresas aglomeradas (Schmitz, ibid.) ${ }^{22}$.}

Segundo SCHMITZ, as aglomerações industriais não garantem por si sós ganhos econômicos, mas facilitam o aparecimento de características que os favorecem, tais como a divisão do trabalho, especialização das empresas e o surgimento de fornecedores de matérias primas, equipamentos e peças de reposição; agentes comerciais que levam os produtos para mercados distantes (nacionais e internacionais); de fornecedores de serviços especializados (técnicos, financeiros e contábeis); trabalhadores com habilidades específicas para o setor. Além disso, vêm à tona ações conjuntas entre os produtores locais - cooperação entre firmas individuais ou cooperação entre grupos de firmas por meio de associações e consórcios ${ }^{23}$.

É inegável, pois, a capacidade das aglomerações de produzirem efeitos locais, razão pela qual, mesmo diante da ausência de uma política industrial mais robusta nos anos 1990, Estados e Municípios passaram a se interessar por estratégias de desenvolvimento industrial baseadas nas aglomerações. De fato, parte do interesse pelo estudo das aglomerações produtivas e da forma de incentivá-las se deveu, obviamente, ao potencial de sua aplicação na elaboração de estratégias de desenvolvimento produtivo, principalmente em iniciativas com enfoque regionalizado.

Todavia, essas considerações são dependentes de um quadro mais amplo que se compõe das políticas industriais de alcance nacional. Com efeito, não há como assumir de chofre, como se se tratasse de ponto indisputável, que a formulação de políticas de desenvolvimento produtivo seja conveniente e oportuna. Nesta última década reavivou-se o debate acerca das políticas industriais, de modo que se faz necessário adentrar nesse tópico a fim de situar melhor o papel dos APLs no bojo de uma estratégia de política econômica.

\footnotetext{
${ }^{22}$ SUZIGAN, Wilson. "Aglomerações Industriais: Avaliação e Sugestões de Políticas”. em Ministério do Desenvolvimento, Indústria e Comércio Exterior; Instituto Evaldo Lodi. (Org.). Futuro de Indústria: Oportunidades e Desafios - a Reflexão da Universidade. Brasília: Ministério de Desenvolvimento, Indústria e Comércio Exterior, 2001, p. 05. Literalmente, para Schmitz: "Um cluster é definido como a concentração geográfica e setorial de empresas. Tal aglomeração [clustering] traz ganhos de eficiência que as empresas raramente podem obter isoladamente. Estes ganhos são albergados no conceito de eficiência coletiva, definido como a vantagem competiva derivada de economias externas locais e da ação conjunta" em "Collective efficiency and increasing returns". IDS Working Paper $n^{\circ}$.50. Institute of Development Studies, University of Sussex, Brighton, 1997, p. 03

${ }^{23}$ Esse é o apanhado que faz Danilo IGLIORI ao comentar o texto de SCHMITZ em Economia dos Clusters Industriais e Desenvolvimento. op. cit., p. 100.
} 


\subsection{A POLÍTICA INDUSTRIAL E O DESENVOLVIMENTO REGIONAL}

Este tópico visa, pois, fornecer alguns elementos capazes de sintetizar o atual estágio do debate a respeito do papel do Estado no desenvolvimento produtivo, a fim de se melhor entender as medidas de apoio aos APLs no contexto das estratégias estatais de desenvolvimento econômico e, especificamente, de desenvolvimento econômico regionalizado.

Antes de tudo, porém, uma breve nota terminológica, aplicável de todo ao restante do presente texto: verifica-se que as estratégias de desenvolvimento produtivo têm um escopo mais amplo que a simples promoção das atividades do setor industrial. Isso se deve não só à perda do peso relativo do setor secundário na economia nacional e mundial (que cedeu grande espaço para o setor de serviços), mas também às dificuldades na diferenciação categorial de determinadas atividades do processo produtivo. Há inúmeras zonas cinzentas nas quais estão algumas das atividades mais relevantes da economia nacional, como a agroindústria e o setor de software. Pode-se entender que a dificuldade (ou mesmo a inocuidade para fins de política) da categorização das atividades em agrícolas, industriais ou de serviço é expressão de um fenômeno econômico que se evidenciou com mais clareza com a modernidade industrial, mas que se aplica também aos setores tradicionamente entendidos como agrícola e de serviço: as economias de escala. A lógica do industrialismo (divisão do trabalho, especialização e os ganhos de produtividade decorrentes) espraia-se para todos os domínios da vida econômica, de forma que não há um traço essencial dos setores de serviços e agrário que impeça de incluí-los no escopo das políticas de desenvolvimento produtivo.

No mais, a tutela da produção nacional envolve a regulação de diversos mecanismos determinantes da atividade econômica, tal como a educação da mão-de-obra, os investimentos em C\&T, o sistema de comércio internacional; assim é que hoje, estão amalgamadas algumas políticas públicas que já estiveram segregadas ${ }^{24}$. Exemplo disso foram as medidas anunciadas pelo governo federal em 2003 e 2008: a primeira,

\footnotetext{
${ }^{24}$ Para uma discussão sobre a posição da política industrial nas políticas de atividades não industriais, ver o trabalho de Eduardo STRACHMAN: Política Industrial e Instituições. Tese de Doutorado. Unicamp, 2000, especialmente pp. 67-68. Ver também a argumentação de Luciano COUTINHO a respeito da "relação estreita entre as políticas industrial, tecnológica, comercial e regional" em "Marcos e Desafios de uma Política Industrial Contemporânea" em CASTRO, Ana Célia. (Org.). Desenvolvimento em Debate. Rio de Janeiro: MUAD-BNDES, 2002.
} 
denominada Política Industrial, Tecnológica e de Comércio Exterior; a segunda, Política de Desenvolvimento Produtivo, contemplando todos os aspectos enunciados na primeira.

Assim, tem-se que as expressões "política industrial", "política de desenvolvimento produtivo", "política de fomento à produção", "política de desenvolvimento industrial" e assemelhadas devem ser entendidas, aqui, como sinônimos perfeitos. De fato, pode-se considerar que todas essas designações representam medidas cujo propósito é "a promoção da atividade produtiva, na direção de estágios de desenvolvimento superiores aos preexistentes em um determinado espaço nacional, ${ }^{25}$. Nesse sentido, Milton CAMPANÁRIO e Marcello MUNIZ propõem um conceito de política industrial que se mostra suficientemente amplo para abarcar várias concepções sobre o tema; para esses autores: "política industrial é a criação, a implementação, a coordenação e o controle estratégico de instrumentos destinados a ampliar a capacidade produtiva e comercial da indústria, a fim de garantir condições concorrenciais sustentáveis nos mercados interno e externo". 26

As noções sobre as políticas industriais não excluem a possibilidade de que um dos objetivos albergados nos planos de desenvolvimento produtivo seja territorialmente localizado $^{27}$, tampouco são antitéticas a que as políticas de desenvolvimento regional estejam nelas contemplada ${ }^{28}$.

Nas medidas lançadas pelo governo federal em 2003 e 2008, os APLs figuram como instrumentos de aplicação regionalizada das políticas industriais. Na PITCE que o governo federal enunciou em 2003, os APLs figuram como objetivos da política

${ }^{25}$ KUPFER, D.; FERRAZ, J. C. ; PAULA, Germano de. "Política Industrial". em: KUPFER, D.\& HASENCLEVER, L.. (Org.). Economia Industrial: Fundamentos Teóricos e Práticas no Brasil. Rio de Janeiro: Editora Campus, 2002,, p. 545.

${ }^{26}$ CAMPANÁRIO, Milton de Abreu \& SILVA, Marcello Muniz da. "Fundamentos de uma Nova Política Industrial”, em FLEURY, Maria Tereza Leme \& FLEURY, Afonso (org.). Política Industrial 1, São Paulo, PubliFolha/FEA-USP, 2004, p. 14.. Em sentido semelhante: "Política industrial deve ser entendida como o conjunto de incentivos e regulações associadas a ações públicas que podem afetar a alocação inter e intrasetorial de recursos, influenciando a estrutura produtiva e patrimonial, a conduta e o desempenho dos agentes econômicos, em um determinado espaço nacional. Pretende-se aumentar a capacidade produtiva das empresas e setores; para países em desenvolvimento, busca-se alcançar os líderes internacionais; para países avançados, o objetivo é manter a posição de liderança ou avançar sobre competidores de outras nações." FERRAZ, João Carlos, PAULA, Germano Mendes de \& KUPFER, David. "Política Industrial", em KUPFER, David \& HASENCLEVER, Lia. Economia Industrial - Fundamentos Teóricos e Práticos no Brasil, Rio de Janeiro, Campus, 2002, p. 545-546.

${ }^{27}$ Nesse sentido, Ha-Joon CHANG cita autores que incluem dentre os objetivos de política industrial o desenvolvimento regional. Ver CHANG, Ha-Joon. The Political Economy of Industrial Policy, New York, St Martin's Press, 1994, pp. 60-61.

${ }^{28}$ Para uma defesa da política regional como integrante da política industrial ver COUTINHO, Luciano. "Marcos e Desafios de uma Política Industrial Contemporânea", op. cit. 
relacionados ao desenvolvimento regional e como instrumento de modernização industrial $^{29}$. Também a Política de Desenvolvimento Produtivo de 2008 contempla medidas de caráter regional que dão destaque aos APLs. Veja-se:

A importância atribuída à descentralização espacial da produção e do emprego qualificado resultou no programa de regionalização, que tem por objetivo garantir que as ações no âmbito da PDP beneficiem as regiões menos desenvolvidas do País. O foco das ações que compõem este programa, que estará articulado à Política Nacional de Arranjos Produtivos Locais, é a promoção de atividades produtivas no entorno de projetos industriais e de infraestrutura $^{30}$.

No mais, política pública alguma pode ignorar o fato de que os efeitos da atividade econômica espraiam-se de maneira desigual pelo território nacional - algumas localidades apresentam condições de impulsionar o desenvolvimento econômico e dele tirar maior proveito - o que provoca evidentes repercussões no modo pelo qual se planeja a distribuição da riqueza pelo país. Um dos papéis possíveis das políticas industriais, portanto, seria contribuir para que os desequilíbrios regionais fossem sanados ${ }^{31}$.

\footnotetext{
${ }^{29}$ Veja-se trechos do documento que expõe as linhas da PITCE: "A Política Industrial, Tecnológica e de Comércio Exterior busca, no curto prazo, diminuir as restrições externas do país e, no médio e longo prazo, equacionar o desenvolvimento de atividades-chave, de modo a gerar capacitações que permitam ao Brasil aumentar sua competitividade no cenário internacional.Em função dessas definições, a política buscará: (...) Contribuir para o desenvolvimento regional, estimulando iniciativas que valorizem a dimensão espacial e o fortalecimento de arranjos produtivos locais." E no que concerne ao aspecto instrumental: "Três aspectos relativos às necessidades de modernização produtiva merecem destaque(...). O segundo é a dimensão regional, na qual devem ser privilegiados os arranjos produtivos locais. Ou seja, os programas de modernização devem atuar prioritariamente nos arranjos produtivos, aproveitando-se da proximidade das empresas e da facilidade de cooperação entre elas e com instituições tecnológicas e financeiras para a difusão de técnicas de produção e de gestão e ampliação dos negócios. A partir dessas condiçães, os programas de modernização podem se tornar mais ambiciosos, indo em direção à inovação tecnológica, ao adensamento do tecido produtivo e à fabricação de produtos de maior valor agregado. O terceiro aspecto é que a atomização empresarial justifica a adoção de programas concentrados espacialmente. Ou seja, as instituições envolvidas com esses programas devem desincentivar o trabalho atomizado, por empresa, $e$ organizar sua ação de forma a atender um conjunto de empresas ao mesmo tempo. Seja porque os problemas são semelhantes entre firmas de um mesmo setor, seja porque as soluções são mais efetivas quando tratadas em conjunto. Para atingir um conjunto amplo de empresas dispersas geograficamente, é importante a articulação do governo federal com as instâncias locais de poder e com outras instituições com elevada capilaridade, tais como institutos tecnológicos estaduais e municipais, Sebrae e Senai, que implementam programas de extensão gerencial e produtiva".

30 Toda a apresentação da PDP é feita em meio eletrônico. Veja-se o sítio do MIDC na internet: www.desenvolvimento.gov.br/pdp. Cabe notar que, não obstante a referência no documento oficial, não existe em norma alguma o estabelecimento ou a definição de uma Política Nacional de Arranjos Produtivos Locais. A definição do que se trata essa política se dará, na verdade, pela via descritiva, o que constitui parte do propósito desta pesquisa.

${ }^{31}$ A articulação com um plano mais abrangente de desenvolvimento, que leve em consideração a integração inter-regional, é um desafio que se coloca para a adoção de políticas industriais: "A inserção pontual da economia brasileira em certas áreas do comércio internacional beneficiou apenas alguns setores e atividades, diferenciando ainda mais as regiões brasileiras, tanto em termos inter-regionais como intraregionais. Surgem ilhas de prosperidade, especializadas em determinados produtos exportáveis, em meio à
} 
No Brasil, essa orientação regionalista da política industrial deu origem a diversas experiências relevantes. Dentre as mais significativas, estão as iniciativas pioneiras da SUDENE e da SUDAM, que se estabeleceram a partir da década de 1960 e que instituíram um padrão de atuação das entidades estatais voltadas ao desenvolvimento produtivo regional. Todavia, a tônica da política industrial contemporânea parece estar um tanto distante da capacidade de mobilização outrora presente na concretização dos ideários da substituição de importações ou da criação da indústria de base, para citar os marcos mais significativos da história da política industrial brasileira ${ }^{32}$.

Atualmente, discutem-se novos parâmetros de atuação do Estado na busca do desenvolvimento produtivo. As políticas industriais persistem, mas provocam controvérsia em razão da influência das correntes liberais de pensamento na política econômica. Obviamente que isso impacta a reflexão sobre o apoio aos APLs porque tal espécie de medida consubstancia uma seleção interventiva a incidir sobre setor econômico e região geográfica, aparentemente contrariando os imperativos da neutralidade da atuação estatal.

\subsubsection{Condicionantes contemporâneos da política industrial}

A discussão atual sobre política industrial dá-se num contexto diverso daquele em que emergiram as primeiras contribuições teóricas da Economia do Desenvolvimento; o momento histórico é de um capitalismo diferente, porque o Brasil ocupa uma posição diversa daquela em que estava quando do início do processo de substituição de importações e promoção da industrialização. Se a condição de subdesenvolvimento persiste, alteraram-se em grande medida as condições e as regras do jogo da economia global. Para os propósitos do presente estudo, que se interessa, sobretudo, pelas possibilidades de atuação do Estado brasileiro mediante o manejo de um instrumento de desenvolvimento produtivo regional ainda incipiente, é primordial tomar como referência os discursos correntes a respeito das estratégias de desenvolvimento produtivo no debate

estagnação de boa parte do território nacional, os chamados espaços não-competitivos, totalmente à margem do desenvolvimento. O baixo encadeamento das áreas e setores dinâmicos com a estrutura sócioeconômica a qual estão inseridos é agravado com a política federal de privilegiar, exclusivamente, os pólos de competitividade e dinamismo, abandonando os espaços não competitivos à própria sorte, o que pode acabar levando o Brasil à fragmentação nacional”. BERCOVICI, Gilberto. Desigualdades Regionais, Estado e Constituição. São Paulo: Max Limonad, 2003.

${ }^{32}$ Para um histórico da política industrial no Brasil, ver SUZIGAN, Wilson \& FURTADO, João. "Política Industrial e Desenvolvimento". Revista de Economia Política, São Paulo, v. 26, p. 163-185, 2006 e STRACHMAN, Eduardo. Política Industrial e Instituições. Tese de Doutorado. Unicamp, 2000. 
contemporâneo; aspectos historiográficos, ou relativos à reconstrução do debate tal como havido em outras décadas, podem permanecer apenas como pano de fundo.

De fato, muitos autores sustentam que a peculiaridade do contexto econômico internacional atual face a outros momentos marcantes da histórica econômica mundial deve ser levada em consideração na formulação das estratégias nacionais de desenvolvimento produtivo ${ }^{33}$. Dentre os principais aspectos, destacam-se:

(i) Uma nova configuração jurídica do comércio global (regido sobretudo pelos acordos multilaterais e regionais de comércio exterior): desde a criação da Organização Mundial do Comércio, os países que aderiram às regras da entidade passaram a ter certas restrições na utilização de mecanismos clássicos de política industrial, principalmente no que se refere ao subsídio de atividades específicas. Isso, em princípio, significaria um forte entrave ao fomento das indústrias nascentes e demais setores e empreendimentos incipientes, tão comumente objetos de políticas de desenvolvimento regional ${ }^{34}$.

(ii) a existência de cadeias produtivas globais, com predominância dos fluxos intra-industriais (e intrafirma) no comércio internacional de produtos manufaturados $e$ relevância dos investimentos externos diretos: a internacionalização da produção e dos mercados, inserindo a produção doméstica em redes transnacionais, acaba por obrigar que as estratégias de desenvolvimento dos Estados nacionais contemplem as demandas formuladas pelas firmas transnacionais. A criação de um ambiente capaz de atrair investimentos diretos estrangeiros passa a ser relevante e tende a consolidar a atuação estatal a partir do que essas empresas possam obter noutros países ${ }^{35}$. Nesse sentido, pode-

\footnotetext{
33 Segundo André NASSIF “[a] concepção e a adoção de qualquer conjunto de instrumentos de política industrial requerem, antes de tudo, respeito às peculiaridades de seu tempo histórico (...). Isso significa que estratégias válidas na primeira metade do século XX deixaram de ter valor no período de 35 anos que se seguiu à Segunda Guerra Mundial, assim como as profundas mudanças econômicas e institucionais ocorridas na economia mundial, após o primeiro choque do petróleo (1973), tornaram inócuos diversos instrumentos de política industrial e de comércio exterior aplicados anteriormente. Qualquer que seja o formato e os instrumentos de políticas industriais que venham a ser implementados, deverão ser respeitados, pelo menos, três parâmetros, até certo ponto, irrevogáveis". "Uma Proposta de Política Industrial para o

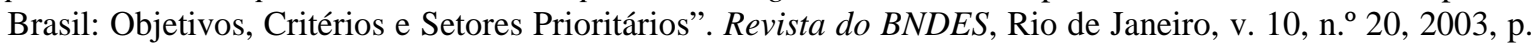
84.

${ }^{34}$ A respeito das restrições oriundas dos tratados de comércio internacional, ver NASSIF, André, "Política Industrial após a Liberalização do Comércio Exterior: O Debate Teórico Contemorâneo". Revista do BNDES, Rio de Janeiro, v. 9, n. 17, 2002; NASSER, Rabih Ali, A OMC e os Países em Desenvolvimento. São Paulo: Aduaneiras, 2003; e CHANG, Ha-Joon. Chutando a Escada: A Estratégia do Desenvolvimento em Perspectiva Histórica. São Paulo: Unesp, 2004.

${ }^{35}$ Veja-se o comentário de André NASSIF: "Se o risco de opção por estratégias de investimento (sobretudo em setores de alta tecnologia) impulsionado predominantemente por empresas locais não fosse tão elevado como no passado, evidentemente seria essa a melhor alternativa para o Brasil numa perspectiva de longo prazo. Entretanto, essa opção não é mais viável (pelo menos quando se ponderam os riscos e custos
} 
se até mesmo afirmar que haveria uma espécie de debilidade dos "centros nacionais de decisão e comando sobre os destinos de qualquer espaço nacional"36.

(iii) a importância da inovação como um determinante do desempenho econômico dos países e firmas: é corrente o diagnóstico de que a capacidade de gestão do conhecimento é cada vez mais importante, senão preponderante, na determinação do desempenho econômico das empresas e países. O domínio das atividades de elevado conteúdo inovativo, muitas delas intensivas em tecnologia, tem se mostrado de tal forma importante que a quase totalidade dos países tem destinado políticas específicas de apoio à inovação tecnológica. Daí decorre um grande debate a respeito da formulação de sistemas nacionais de inovação e seus desafios ${ }^{37}$.

Esses três elementos citados produzem um paradoxo que resume o desafio da formulação das políticas de desenvolvimento contemporâneas: ao mesmo tempo em que fazem os instrumentos tradicionais de proteção das economias domésticas perderem espaço de aplicação, exigem, mais do que nunca, uma política industrial bastante contundente principalmente diante do fato de que a modificação das escalas de produção, que passam agora, em vários setores, a ter como referência mercados globais, parece forçar os Estado nacionais a formularem políticas de robustecimento de seu setor produtivo, sob pena de que as firmas nacionais percam espaço para competidores estrangeiros (o que refletiria negativamente na geração de renda e emprego internos).

envolvidos), dados o elevado grau de internacionalização da economia brasileira nesses setores e as evidências descritas no item anterior. Além disso, em virtude da intensa mobilidade dos fluxos internacionais de bens, serviços e fatores produtivos (exceto trabalho), capitaneados pelas empresas multinacionais, o papel do investimento externo direto (IED) já é e tende a ser ainda mais relevante para as estratégias de inserção global do que no passado. Isso significa que a opção de menor risco relativo para o Brasil é propiciar um ambiente propício à atração de investimentos externos, preferencialmente nos setores produtores de bens comercializáveis (tradeables) e de maior intensidade tecnológica. Além disso, como há evidências de forte acirramento da competição entre países em desenvolvimento pela atração de IED, dada a intensificação dos incentivos fiscais e de crédito para esse fim [ver IDC (2000)], a consecução de um ambiente micro e macroeconômico é condição necessária, mas não suficiente, para aumentar os influxos de investimento externo em setores mais intensivos em tecnologia. Essas indústras são as que trazem os maiores benefícios econômicos a longo prazo, mas também as que incorporam os maiores riscos para os países em desenvolvimento, seja devido à forte concorrência global, seja porque a constituição e a preservação de sua competitividade dependem de uma variedade de fatores complementares, tais como os gastos elevados em infra-estrutura física, de ciência e tecnologia e educacional". "Uma Proposta de Política Industrial para o Brasil: Objetivos, Critérios e Setores Prioritários”. Revista do BNDES, Rio de Janeiro, v. 10, n. ${ }^{20,} 2003$, p. 85.

${ }^{36}$ A expressão é de Carlos BRANDÂO em Território \& Desenvolvimento: As Múltiplas Escalas entre o Local e o Global. Campinas, Editora Unicamp, 2007, p. 35.

37 Para uma síntese dos desafios de política de ciência, tecnologia e inovação no Brasil, ver o trabalho de LAPLANE, Mariano, CASSSIOLATO, José Eduardo \& LASTRES, Helena. Projeto Política Brasileira de Ciência,Tecnologia e Inovação: A Lei de Inovação e o Sistema Nacional de $C \& T$ \& I. Centro de Gestão e Estudos Estratégicos, Rio de Janeiro, 2007. 
De todo modo, fato é que a crescente importância relativa dos mercados externos para todas as regiões brasileiras nos últimos anos produz efeitos inter-regionais que impõem novos desafios à promoção do desenvolvimento produtivo e à redução das desigualdades regionais, principalmente no que toca à manutenção do equilíbrio federativo e da integração produtiva nacional ${ }^{38}$. Obviamente, as estruturas produtivas distribuídas pelo Brasil afora não gozam de condições equânimes; elas variam, e muito, no que concerne à capacidade de atuar no mercado aberto à competição externa, por motivos diversos (que podem significar tanto vantagens quanto desvantagens competitivas face às firmas estrangeiras): maturação tecnológica, custos de transporte e mão-de-obra, demanda pelo produto.

Tem-se, então, a criação de uma tensão entre os objetivos da ação estatal ligados à promoção dos setores da economia nacional com maiores possibilidades de êxito na competição global e a busca pela redução das desigualdades regionais. O dilema alocativo que tal estado de coisas provoca é, pois, latente: seja para garantir a sobrevivência da economia nacional face à competição externa, seja para incrementar sua boa performance e ajudá-la a angariar mercados mundo afora, a participação do Estado, hoje como outrora ${ }^{39}$, afigura-se essencial. Dentro dessa perspectiva, a questão das desigualdades regionais afigura-se como central.

\footnotetext{
38 "Nos últimos tempos, tem aumentado a importância relativa dos mercados externos para todas as regiões brasileiras, vistos como maneira de dinamizar a produção regional, compensando a crise econômica interna. Pela lógica do mercado, as principais atividades econômicas devem reconcentrar-se nas regiões mais industrializadas e de maior nível tecnológico, fazendo com que as áreas periféricas detentoras de estruturas econômicas especializadas busquem articular-se, técnica e economicamente, com o mercado mundial. Desta maneira, a opção centrífuga de integração regional com o exterior é fortalecida, em prejuízo das articulações agregadoras em nível nacional, o que dificulta extremamente a recomposição do pacto federativo brasileiro, além de possibilitar o rompimento da integração regional, fragmentando a economia nacional'.Gilberto BERCOVICI, Desigualdades Regionais, Estado e Constituição, São Paulo, Max Limonad, 2003, pp. 259-260.

${ }^{39}$ O papel do Estado na transformação da estrutura produtiva é bem sumarizado por Luciano Coutinho, que arrola alguns dos instrumentos empregados em tal estratégia: Não resta dúvida - para qualquer analista sério e informado - que o desdobramento e a concretização dos processos de industrialização dos países periféricos dependeram diretamente da iniciativa, fomento e coordenação por parte do Estado. Desde logo coube ao Estado estruturar e alocar meios de crédito e de capitalização, com taxas de juros baixas e prazos relativamente longos. Além do funcionamento, um conjunto de instrumentos tributários e tarifários foram manejados para aumentar as taxas de lucros dos empreendimentos (e.g., proteção aduaneira via tarifa, isençães fiscais sobre a produção elou sobre os lucros, isençães fiscais sobre a importação de equipamentos, esquemas de depreciação acelerada, etc.). Regulamentos e normas também foram comumente utilizados (e.g. licenças de importação, controles sobre remessas financeiras, reservas de mercado e restrições à entrada, monopólios legais, incentivos a fusões, normas técnicas, etc). Pode-se ainda citar o uso de incentivos e créditos fiscais à exportação e, no caso coreano, às atividades de $P \& D$. Todas essas práticas foram fundamentais para reduzir o grau de risco, elevar a taxa de retorno e viabilizar financeiramente a realização dos investimentos pelo setor privado elou pelas empresas estatais". COUTINHO, Luciano. "Coréia do Sul e Brasil: Paralelos, Sucessos e Desastres." em FIORI, José L. Estados e Moedas no Desenvolvimento das Nações. Petrópolis: Vozes, 1999, p. 357
} 


\subsubsection{Modelos de política industrial}

A política industrial, como política pública que e ${ }^{40}$, expressa uma seleção de valores e objetivos a partir de uma determinada interpretação da realidade econômica por quem a formula e a pretende executar. Os discursos relacionados ao tema possuem, então, três dimensões relativamente autônomas que devem ser consideradas: (i) o diagnóstico de uma realidade fática a ensejar a ação estatal; (ii) o prognóstico de curto, médio e longo prazo desse quadro fático analisado, a fim de amparar as estratégias de atuação governamental; e (iii) a proposição de medidas aptas a atingir as finalidades públicas almejadas. Das múltiplas possibilidades de análise de cada um desses aspetos envolvidos na formulação e implementação de política pública, decorre a dificuldade de se estabelecer consensos a respeito das melhores estratégias de desenvolvimento produtivo que os Estados nacionais podem adotar.

(i) Como veremos adiante, há divergências significativas entre as grandes correntes de pensamento econômico sobre a configuração dos mercados e isso, por si só, induz à falta de consenso a respeito da melhor estratégia de atuação a ser adotada pelo Estado em face de cada situação que se lhe apresente. Com efeito, numa região economicamente deprimida, onde um observador desenvolvimentista pode enxergar falta da ação estatal tendo em vista a promoção de mercados e indústrias capazes de alterar a estrutura local, uma avaliação sob a perspectiva ortodoxa pode concluir pela simples inexistência de elementos que ensejem a realização de atividades econômicas, carecendo o local de vantagens comparativas; isso é, não haveria, em princípio, nada de errado com a região analisada.

(ii) Ainda que houvesse consenso absoluto no diagnóstico da realidade econômica, qualquer decisão que dele decorresse estaria sujeita a riscos de malogro simplesmente pela imponderabilidade das alterações no cenário econômico - ou seja, o que é pertinente e proveitoso agora pode não o ser num futuro próximo, e isso depende de uma pluralidade de fatores que normalmente escapam do controle das autoridades econômicas. Mercados e

\footnotetext{
${ }^{40}$ A ideia de política pública que se utilizará aqui é a de Maria Paula Dallari BUCCI: "Políticas públicas são programas de ação governamental visando a coordenar os meios à disposição do Estado e as atividades privadas, para realização de objetivos socialmente relevantes e politicamente determinados. Políticas Públicas são 'metas coletivas conscientes' e como tais, um problema de direito público, em sentido lato" em Direito Administrativo e Políticas Públicas, São Paulo, Saraiva, 2002, p. 241. Para uma discussão sobre a política industrial como política pública, ver o trabalho de Mário Gomes SCHAPIRO: Política Industrial e Disciplina da Concorrência pós-Reformas de Mercado - Uma Avaliação Institucional do Ambiente de Inovação Tecnológica. Mestrado em Direito Econômico, USP, 2005, especialmente as pp. 88-94.
} 
empreendimentos promissores podem virar natimortos se, na dependência de incentivo estatal, restarem ignorados ou forem promovidos com atraso; ou, do mesmo modo, atividades beneficiadas por pesados incentivos e subsídios podem se revelar inviáveis. A incerteza sobre o cumprimento dos propósitos da ação estatal se agrava por conta do tempo exigido para que os projetos concebidos atinjam os resultados que deles se espera, sendo certo que, na hipótese de lograrem êxito, podem demorar décadas, o que, além de denotar a forte vinculação entre a tutela estatal da economia industrial e a atividade de planejamento do Estado, pode levar a avaliações equivocadas (porque prematuras) das políticas públicas $^{41}$.

(iii) E como se não bastassem as divergências de interpretação da realidade econômica, há ainda as diferenças relacionadas aos instrumentos e objetivos que se prescrevem como políticas de desenvolvimento produtivo. Pode-se entender, na verdade, que o dissenso verificado nesse quesito é determinado pelas leituras possíveis da realidade econômica. Como a política industrial não decorre de uma análise técnica que revele com precisão absoluta a maneira pela qual o Estado deva agir (ou se abster), não se tem um receituário de como e onde agir; por mais criterioso e embasado que seja o processo decisório sobre as políticas industriais, ele sempre será passível de refutações. E, nesse sentido, todo o debate que envolve as proposições e formulações de políticas industriais é político, no sentido forte do termo, isto é, ele encontra resolução na escolha de determinados valores e objetivos - "política industrial é antes de tudo uma atitude, e só depois uma questão técnica ${ }^{42}$.

Os discursos correntes (tanto os puramente teóricos quanto os dos agentes estatais responsáveis pela implementação das políticas públicas) expressam uma seleção e

\footnotetext{
${ }^{41}$ Essa dificuldade de avaliação peremptória do êxito de determinadas políticas industriais é bem expresso no exemplo da Embraer. Como anotan SUZIGAN \& FURTADO: "Até o final dos anos de 1980 e o início dos anos de 1990, a EMBRAER ainda era considerada, por muitos, um empreendimento situado entre o fracasso estrondoso e o êxito muito oneroso. Para alguns, era mais uma dessas 'jabuticabas artificiais' que o Brasil insiste em fazer, contrariando vocações e desperdiçando oportunidades. Essa crítica mostra-se hoje inteiramente descabida e o silêncio desses críticos (inclusive com relação às suas posições anteriores) é bastante compreensível. O sucesso da Embraer nos anos de 1990 possui antecedentes próximos e remotos. Os mais recentes estão nos anos de 1950, com a criação da instituição formadora dos recursos humanos avançados do setor, e os longínquos remontam aos anos de 1920 e 1930, quando se formaram as principais teses a respeito das necessidades e possibilidades brasileiras em termos de indústria aeronáutica. Nada menos de meio século separa o embrião dos seus frutos, um intervalo em que recursos abundantes regaram o terreno fértil das idéias e capacidades, até que os aviões se tornassem um item relevante da nossa pauta exportadora". "Política Industrial e Desenvolvimento". Revista de Economia Política, São Paulo, v. 26, 2006, p. 176-177.

${ }^{42}$ A frase é de C. JOHNSON, citado em SUZIGAN, Wilson. \& FURTADO, João Política Industrial e Desenvolvimento. Revista de Economia Política, São Paulo, v. 26, p. 168.
} 
prevalência de determinados objetivos e valores em detrimento dos demais ${ }^{43}$. Por exemplo, sob uma perspectiva ideológica que valorize acima de tudo a igualdade formal entre os sujeitos submetidos à regulação estatal, a adoção de uma política industrial setorializada seria indesejável. De outro lado, ainda sob a perspectiva da igualdade formal, e considerando-se uma realidade de grandes disparidades entre os agentes econômicos, poder-se-ia argumentar que a ausência de incentivo a determinados setores, na verdade, apenas consolida uma desigualdade prevalecente.

As decisões sobre o que se espera promover (setores, empresas, classes sociais, regiões) e como isso será feito (qual dos diversos instrumentos será empregado) implicam, como em qualquer escolha de política pública (que por princípio envolve o manejo de recursos escassos), uma discriminação entre beneficiados e não beneficiados: no fim das contas, o recurso público deixará de atender a um e irá prover o outro. Tem-se um resultado que não é neutro do ponto de vista axiológico, havendo ganhadores e perdedores, bem como ganhos reduzidos ou perdas acentuadas devidos à atuação ou omissão do Estado. Ou seja, há tensões de toda sorte na formulação e implementação de uma política industrial. Como afirma Chang:

quase todo mundo concorda que o Estado tem um papel a cumprir, mas há pouco acordo sobre quando e como ele deve agir. Talvez a razão pela qual exista tão pouca concordância é que a intervenção do Estado é um fenômeno complexo, envolvendo muitos problemas controversos, como eficiência, moralidade, poder, liberdade e legitimidade, para citar somente uns poucos ${ }^{44}$.

Contudo, não obstante ter-se sugerido que a discussão é quase ilimitada, pode-se identificar a origem das principais controvérsias em duas concepções primordiais a respeito do papel do Estado na economia.

A primeira concepção, que se nomeará aqui liberal, prescreve que o Estado, ao atuar tendo em vista o desenvolvimento produtivo, não deve privilegiar setores, classes sociais ou regiões, mas conduzir uma política econômica que favoreça indistintamente os agentes econômicos. A segunda concepção, por sua vez, que se denominará

\footnotetext{
${ }^{43}$ A esse respeito, ver MYRDAL, Gunnar. Aspectos Políticos da Teoria Econômica - especialmente o cap. 08 - "O Papel da Economia na Política".

${ }^{44}$ Citador por Eduardo STACHMAN em Política Industrial e Instituições. Tese de Doutorado. Unicamp, 2000, p. 23.
} 
intervencionista, confere ao Estado uma atuação muito mais incisiva na promoção de determinados setores e atividades ${ }^{45}$.

Não se ignora que a pretensão de reduzir as posturas ideológicas da política industrial a somente duas categorias pode empobrecer bastante a visão de determinados autores, mas é possível identificar nelas a origem das principais teses favoráveis e contrárias à adoção de mecanismos de incentivo à produção. A seguir, propõe-se uma tipologia dessas concepções, anunciando-se os argumentos que as sustentam bem como o conteúdo das políticas industriais recomendadas.

\subsubsection{A posição liberal, as medidas de caráter horizontal e os argumentos contrários à} intervenção setorial.

A posição liberal identifica-se com os pressupostos da teoria econômica ortodoxa (ou neoclássica), que baseia a descrição dos mercados perfeitos nos modelos de equilíbrio e considera, portanto, que a intervenção estatal nos mercados prejudica a alocação ótima de recurso. Essa justificativa genérica de defesa da racionalidade do mercado pode ser detalhada em alguns sub-argumentos, que sustentam que a intervenção estatal provoca problemas alocativos e que, portanto, deve ser evitada, tais como o argumento das falhas de governo; da autonomia do interesse do Estado, dos riscos de cooptação do Estado; e da lentidão para percorrer a curva de aprendizagem, desestimulando a eficiência das firmas ${ }^{46}$.

45 Essa tipologia dicotômica segue uma clássica divisão reconhecida na literatura econômica entre "ortodoxos" (ou neoclássicos) e heterodoxos. Para mais classificações em que se demarcam as diferenças entre ortodoxos e as concepções que conferem um papel mais ativo ao Estado, ver KUPFER, David; FERRAZ, João C. \& DE PAULA, Germano. "Política Industrial”, em KUPFER, David \& HASENCLEVER, Lia.. (Org.). Economia Industrial: Fundamentos Teóricos e Práticas no Brasil. Rio de Janeiro: Campus, 2002, em que se tem uma distinção entre políticas industriais pela ótica das falhas de mercado, pela ótica desenvolvimentista e pela ótica da inovação. ERBER \& CASSIOLATO, por sua vez, apresentam uma tipologia bastante assemelhada ao estabelecerem quatro visões do desenvolvimento industrial que conformariam uma agenda das políticas do setor. Os autores nomeiam as perspectivas identificadas no espectro econômico-ideológico "neoliberal radical" (que reduz o papel do Estado a um tímido gestor macroeconômico), "neo-liberal reformista" (que concede maior espaço ao Estado na correção das imperfeições de mercado), neo-desenvolvimentista (que dá grande ênfase ao papel do Estado como agente construtor do processo econômico) e "social democrata" (cuja preocupação maior é a resolução de problemas sociais, tais como o desemprego e o acesso da população de baixa renda aos serviços essenciais). em Política Industrial - Teoria e Prática no Brasil e na OCDE, em Revista de Economia Política, vol 17, n. 2 (66), abriljunho, 1997.

${ }^{46}$ Para a exposição dos argumentos que repelem de maneira mais drástica a intervenção do Estado na economia, ver NASSIF, André. "Uma Contribuição ao Debate sobre a Nova Política Industrial Brasileira". Rio de Janeiro: BNDES, 2003 e CHANG, Ha-Joon, The Political Economy of Industrial Policy. New York: St Martin's Press, 1994, e Eduardo STRACHMAN. Política Industrial e Instituições. Tese de Doutorado. Unicamp, 2000. 
Contudo, mesmo as opiniões mais extremadas vinculadas à ortodoxia econômica admitem que, para além dos modelos teóricos de concorrência perfeita, os mercados concretos possuem imperfeições (falhas) que demandam correções, tendo em vista o alcance da eficiência alocativa ${ }^{47}$. Reconhece-se, assim, a necessidade de atuação do Estado no domínio econômico, mas com alguns condicionantes.

Em primeiro lugar, segundo tal enfoque, qualquer forma de intervenção estatal deve ser de corte horizontal, isto é, devem-se adotar medidas que "dizem respeito a todos os elementos que contribuem para a criação e a manutenção da competitividade da economia em termos sistêmicos. Sua peculiaridade reside no fato de que a concessão de incentivos públicos deve ser neutra com relação aos receptores no âmbito do sistema econômico como um todo"48.

Exemplos de medidas de caráter horizontal seriam o provimento de bens públicos, a manutenção da estabilidade de preços (política antiinflacionária), a garantia de um sistema tributário adequado, investimento em infra-estrutura de amplo acesso e uso ${ }^{49}$, educação (ensino básico, superior e técnico), e criação de mecanismos de integração entre entidades de pesquisa e empresas ${ }^{50}$.

Diante de medidas de política econômica que conferissem tratamento indistinto aos diversos setores da economia, não haveria razão sequer para se falar em "política industrial"; ter-se-ia tão somente a implementação de dimensões da política econômica (monetária, cambial, fiscal) que repercutissem no processo produtivo. A neutralidade da atuação do Estado só seria rompida para fins de saneamento de falhas de mercado, na

\footnotetext{
47 A discussão a respeito das falhas de mercado adquire especial relevo quando se trata das políticas de desenvolvimento produtivo ou de qualquer outra espécie de política econômica que diga respeito à totalidade da economia. Isto porque, apesar de as falhas de mercado serem usualmente tratadas no âmbito da racionalidade de um setor específico, nesse caso, a intervenção estatal se justifica principalmente pelos efeitos de saneamento das falhas no restante da economia. A importância da análise dos efeitos da intervenção em determinado mercado se destaca ainda mais nos setores de insumos básicos, como o petroquímico ou o de bens de capital. Dependendo da situação, a intervenção estatal no saneamento das falhas de mercado é definidora da subsistência do setor. Pense-se nos investimentos em C\&T do setor petrolífero no Brasil.

48 NASSIF, André. "Uma Proposta de Política Industrial para o Brasil: Objetivos, Critérios e Setores Prioritários". Revista do BNDES, Rio de Janeiro, v. 10, n. ${ }^{\circ}$ 20, 2003.

${ }^{49}$ Acentua-se o caráter da amplitude do uso e acesso da infra-estrutura para diferencias as infra-estruturas que sirvam a interesses bem identificados (ex: uma via de transporte que favoreça uma empresa específica nessa perspectiva, investimento em infra-estrutura pode ser um instrumento de intervenção setorial.

50 NASSIF, André. "Uma Proposta de Política Industrial para o Brasil: Objetivos, Critérios e Setores Prioritários". Revista do BNDES, Rio de Janeiro, v. 10, n. ${ }^{\circ} 20,2003$, p. 87.
} 
medida em que tal intervenção representasse uma busca do equilíbrio geral ${ }^{51}$. Assim é que surgem as questões da identificação das falhas de mercado e da intensidade da intervenção estatal exigida para o saneamento de tais falhas ${ }^{52}$.

Mas, independente das escolhas que se façam em política industrial sob essa perspectiva liberal ou "horizontalista", uma primeira característica que nela se observa é o seu caráter reativo. De fato, partindo-se do pressuposto de que o mercado atinge seus propósitos alocativos de maneira espontânea, a intervenção só faz sentido após a identificação das causas que induzem a economia a um equilíbrio sub-ótimo ${ }^{53}$. Nessa perspectiva, a formulação de uma política industrial setorializada e regionalizada, tal como se dá com a promoção dos APLs, poderia representar um caso extremo de intervenção provocadora de desequilíbrios alocativos, a não ser que se pudesse identificar a ação estatal simplesmente como forma de correção de falhas de mercado pontuais que atingissem cada arrranjo.

${ }^{51}$ Como sintizam KUPFER, FERRAZ \& DE PAULA, "na visão neoclássica o mercado competitivo é o alocador eficiente de recursos. Supondo informação perfeita e reversibilidade sem ônus das decisões, os agentes racionais realizam escolhas que maximizam não apenas o seu bem-estar individual, mas também o coletivo. A livre mobilidade dos fatores e o atomismo dos agentes levam a que o mecanismo de demanda e oferta determine preços de equilíbrio ótimos do ponto de vista social, significando que qualquer aumento extra na utilidade de um grupo específico somente pode ser atingido à expensas da utilidade de um outro grupo. Portanto, se todos os mercados forem competitivos, a política industrial não é somente desnecessária como, principalmente, indesejável. Analogamente, a intervenção governamental seria neessária se, e somente se, o mecanismo de preços não capturasse todos os benefícios e custos de oportunidade associados à produção e ao consumo de bens. Nessas situações ocorrem o que os economistas clássicos chamam de falhas de mercado. Pelas óticas das falhas de mercado, a intervenção pública é passiva, mirando somente as condições de funcionamento subótimo da alocação via mercados competitivos. Somente nesses casos o custo de intervenção pública poderia ser inferior aos benefícios potenciais a serem produzidos. (...) Em resumo, se os mercados falham em prover o uso eficiente de recursos, existiriam, em tese, espaços para a intervenção pública, na forma de políticas industriais. Assim, segundo uma perspectiva ortodoxa, a política industrial teria finalidade essencialmente corretiva, no sentido de amenizar os impactos negativos das falhas de mercado". Política Industrial. Kupfer, David \& Hasenclever, Lia. (Org.). Economia Industrial: Fundamentos Teóricos e Práticas no Brasil. Rio de Janeiro: Editora Campus, 2002, pp 549-550 e 552.

${ }^{52}$ Para uma discussão do caso brasileiro e uma defesa da adoção da política industrial como correção das falhas de mercado, ver FERREIRA, Pedro Cavalcanti Gomes; PESSÔA, S. A.; SCHYMURA, Luiz Guilherme \&CANEDO, Maurício . "O Brasil Precisa de uma Política Industrial? De que tipo?". Rio de Janeiro: FGV. Ensaios Econômicos, n. ${ }^{\circ}$ 644, 2007.

${ }^{53}$ Wilson SUZIGAN \& João FURTADO, ao esboçarem um perfil da visão liberal, sintetizam bem esse aspecto: "Grande parte da controvérsia em torno da definição e do escopo da PI tem a ver com diferentes visões sobre seus fundamentos teóricos. Autores de extração liberal utilizam um arcabouço de teoria formal para justificar intervenções por meio de política industrial como forma de sanar falhas ou imperfeições de mercado, tais como externalidades, bens públicos, incerteza, informação insuficiente ou assimétrica, sob o pressuposto de que a economia se encontra numa trajetória de equilíbrio sub-ótimo, e com os supostos de racionalidade substantiva de agentes com comportamento maximizador, estruturas industriais dadas $e$ conhecimento disponível como um bem livre. Nessa visão, a PI seria meramente reativa e restrita, especificamente direcionada a remediar as imperfeições de mercado e de natureza horizontal, isto é, não seletiva em termos de setores ou atividades. E mesmo assim as intervenções somente se justificariam quando seus benefícios não fossem inferiores aos seus custos em termos de falhas de governo (ou da burocracia) $e$ de rent-seeking" (grifou-se). "Política Industrial e Desenvolvimento". Revista de Economia Política, São Paulo, v. 26, 2006, p. 164. 


\subsubsection{A posição intervencionista e as medidas de caráter vertical}

A concepção que aqui se denomina intervencionista agrupa correntes teóricas de diversos matizes, que por vezes diferem bastante no que respeita aos objetivos da intervenção estatal. Há desde posições muito próximas às mais liberais, que sustentam intervenções pontuais em setores estratégicos, até as que submetem a lógica da política industrial a objetivos de políticas sociais.

Contudo, independente da noção peculiar de desenvolvimento que possam ter essas correntes, todas elas comungam da premissa de que o Estado é agente fundamental do processo econômico e possui papel primordial na condução de uma série de processos fundamentais ao desenvolvimento, de forma que deve adotar políticas específicas de apoio a determinados setores e atividades. Não se trata de negar a importância do mercado nem mesmo a necessidade das medidas de corte horizontal em prol da totalidade do ambiente econômico, mas de reconhecer a insuficiência do livre mercado na consecução de alguns objetivos de economia política, dentre os quais o incremento da competitividade das empresas nacionais e da economia nacional em face de seus concorrentes internacionais, a sustentação de um quadro positivo do balanço de pagamentos e a geração de empregos em quantidade e qualidade.

Para tanto, faz-se necessário agir de maneira específica, fomentando setores que se considerem importantes para a consecução desses objetivos mais gerais de política econômica. Nessa perspectiva, a política industrial exige, sim, seleção de setores e atividades que realmente demandem a adoção de medidas concretas em seu favor.

Todavia, até que ponto as concepções de política industrial aqui tratadas seriam realmente inconciliáveis? Considerando-se uma economia nacional composta por uma diversidade enorme de situações locais, não é nenhum disparate cogitar a conciliação de diferentes concepções no interior de uma mesma e una política econômica. Há dimensões muito diversas na realidade econômica brasileira.

Nessa perspectiva intervencionista é mais fácil compreender a promoção dos APLs. Aqui se albergam razões de promoção de políticas setorializadas e regionalizadas. As aglomerações podem aglutinar políticas de promoção de mercados incipientes, de capacitação de mão-de-obra, de desenvolvimento tecnológico, podem, enfim, ser o foco de uma densa composição de incentivos estatais. Isso não significa, entretanto, que na perspectiva liberal o fomento aos APLs deixe de ser considerado, ou, pelo menos tolerado. 
Isto depende do tipo de intervenção admitida sobre o Arranjo. Na medida em que se busque precipuamente promover as economias externas decorrentes da aglomeração, ou seja, desde que não se realize uma interferência incisiva nos mercados, mas apenas se almeje a produção de resultados pelo manejo de fatores externos à atividade produtiva, passíveis de serem replicáveis independentemente da localização e das perculiaridades produtivas do arranjo, medidas de incentivo (ex: promoção de marcas coletivas, apoio a formação de consórcios de exportação, criação de instrumentos de garantia de crédito coletivos) são autorizadas.

No mais, a própria escolha dos APLs como instrumento do desenvolvimento pode ser discutida à luz das racionalidaes presentes na tipologia de intervenção aqui adotada. Em determinadas situações e regiões, talvez a promoção dos APLs não seja mesmo o investimento público mais adequado para se obter desenvolvimento produtivo, geração de emprego, renda etc, eis que o custo dessa medida pode não se justificar em face de benefícios diminutos em que ela resulte. Há de se observar minimamante as possibilidades efetivas de o fomento estatal lograr o desenvolvimento produtivo em cada contexto: até que ponto vale a pena investir numa cultura agrícola que não se mostrou adapatada a um determinado tipo de solo de uma região; ou investir num projeto de industrialização em região desprovida de estrutura de transporte suficiente para fazer escoar a produção ou incapaz de atrair a mão-de-obra necessária? Por outro lado, em determinados setores mais consolidadeo, por vezes simples medidas horizontais, como a desoneração fiscal, mostramse suficientes para promover adequadamente a indústria.

Por isso é que a seleção dos mecanismos de política pública aptos a propiciar o desenvolvimento produtivo exige uma ponderação a respeito do tipo de intervenção necessário. Isso remete diretamente à questão do instrumentos de que o Estado pode se valer em tal tarefa. Importa, então, examinar como isso pode se materializar em política pública. É nesse ponto que se exige a análise do ordenamento jurídico, desde o seu nível mais fundamental - a Constituição da República, da qual se extraem as bases normativas das políticas públicas de desenvolvimento regional - até o arcabouço burocráticoinstitucional, aqui entendidas as entidades administrativas voltadas à tutela das atividades estatais concernentes ao tema. 


\subsection{OS FUNDAMENTOS NORMATIVOS DO DESENVOLVIMENTO REGIONAL}

Os temas da desigualdade regional e do desenvolvimento aparecem de maneira pronunciada num dispositivo topologicamente importante do texto constitucional: o célebre art. $3^{\mathrm{o}^{54}}$, exemplo de norma que consagra um objetivo e institui missões fundamentais do Estado brasileiro, e que, por esse motivo pode ser classificado de "cláusula transformadora" 55 . É no diminuto Título I da Constituição, respeitante aos seus princípios fundamentais - o qual, de tão poucos dispositivos que abarca, afigura-se como o mais exclusivista dos Títulos do texto constitucional - que reside a formulação dos objetivos primordiais da ação do Estado brasileiro. Dentre outras cláusulas dotadas desse mesmo estatuto (e atributo) transformador, tem-se a instituição da garantia do desenvolvimento nacional (inc. II) e da erradicação da pobreza e da marginalização, bem como a redução das desigualdades sociais e regionais (inc. III). Encontramos, nesses dispositivos, uma fórmula singela, mas politicamente densa, de enunciar a condição de subdesenvolvimento brasileiro e estabelecer a desigualdade (regional e social) como um dado. $\mathrm{O}$ que se coloca como objetivo no texto normativo acaba por denunciar o quadro fático cuja superação se espera, e é nesse sentido que o desenvolvimento nacional se articula com as desigualdades regionais: almeja-se que estas se desfaçam em razão da realização daquele. Do moesmo modo, a igualação das condições de vida, tanto no plano das classes sociais como no das regiões não deve resultar da simples distribuição da riqueza existente, mas também da criação de um excedente a ser distribuído.

Não está inscrito no texto constitucional que todo o processo de desenvolvimento se resume na sua faceta econômica, no sentido do crescimento da riqueza nacional total. Ao contrário, aponta-se para a possibilidade de estabelecer uma vinculação entre a igualação das condições de vida (o que se pressupõe nos desafios da redução das desigualdades sociais e regionais) e o incremento da riqueza material da sociedade em determinados termos. Apesar de se poder afirmar que o reconhecimento desse vínculo é possível nos termos principiológicos do art. $3^{\circ}$, sendo certo que os temas, pois, estão colocados na Constituição, não estão nela os termos da resolução da questão regional. Ela

\footnotetext{
54 "Art. $3^{\circ}$ Constituem objetivos fundamentais da República Federativa do Brasil: I - construir uma sociedade livre, justa e solidária; II - garantir o desenvolvimento nacional; III - erradicar a pobreza e a marginalização e reduzir as desigualdades sociais e regionais; IV - promover o bem de todos, sem preconceitos de origem, raça, sexo, cor, idade e quaisquer outras formas de discriminação."

55 BERCOVICI, Gilberto. Constituição Econômica e Desenvolvimento: Uma Leitura a partir da Constituição de 1988. São Paulo: Malheiros, 2005, pp. 36-37.
} 
aponta alguns caminhos, estabelece algumas providências, mas não dá conta da complexidade do tema em sua inteireza. Para tratar apenas de um dos problemas decorrentes da incidência do art. $3^{\circ}$, é de se apontar que a Constituição ignora as múltiplas escalas geográficas da desigualdade - isto é, os inúmeros espaços econômicos criados e configurados segundo referências outras que não as das macrorregiões citadas no texto constitucional (NE, NO).

Ora, se a igualação das condições de vida deve se dar no território nacional como um todo, os mecanismos legítimos de redução das desigualdades regionais têm de ser aplicados com base em diversos espaços econômicos (independente de quais e de onde sejam) e não somente em grandes espaços geográficos. Com isto se pretende dizer que a desigualdade verificada entre a região Sul e a Nordeste não é a única que deva ser legitimamente combatida; a desigualdade pode ser igualmente gritante entre uma metrópole do sudeste e uma região que lhe diste menos de $100 \mathrm{~km}$; conquanto a Constituição dê mais destaque àquela, não se pode dizer que outros referenciais espaciais não possam ser usados - principalmente se verificado que políticas públicas com esse tipo de foco são as mais eficazes.

\subsubsection{Constituição e região}

A discussão sobre a noção de região no texto constitucional é especialmente importante aqui para que se possa evidenciar a escala que deve ser adotada na ação estatal, de modo a se avaliar, mais à frente, se as políticas de promoção dos APLs se adequam à amplitude da ação governamental atribuída pela Constituição nesse tocante.

Identificam-se no texto da Constituição alguns dispositivos que tratam da questão regional, todos eles com a evidente finalidade de instituir um campo de ação próprio, no qual o Estado deva atuar com especial intensidade. Mas eles não possuem uma linha nítida de convergência, da qual se possa inferir um plano de ação claro e suficiente. Aliás, sequer existe um conceito unívoco de região no texto constitucional, o que não chega a ser propriamente um problema, pois o termo aparece em cada contexto num registro diferente, indicando realidades específicas sobre as quais o Estado deva tomar providências. Destacam-se aqui três passagens em que o texto constitucional dispõe sobre questões pertinentes ao tema desta dissertação ("i" a "iii”" abaixo). 
(i) No art. $25, \S 3^{\circ}$, ao tratar das competências dos Estados federados, autoriza que eles instituam, mediante lei complementar, "regiões metropolitanas, aglomerações urbanas e microrregiões, constituídas por agrupamentos de municípios limítrofes, para integrar a organização, o planejamento e a execução de funções públicas de interesse comum". Como se vê, o único requisito a ser observado na criação dessas formações é que os municípios que as componham sejam contíguos. Também se denota que a finalidade última dessas formações é otimizar o desempenho de atividades que aglutinem interesses dos municípios envolvidos. O objetivo de redução das desigualdades regionais intraestaduais não está explicitamente colocado, mas nada impede que a Constituição de cada Estado se valha de instrumentos próprios para a consecução de tal objetivo. No mais, a otimização da prestação de alguns serviços de interesse comum de Municípios aglomerados em consequência de eventuais ganhos de escala pode ser obtida pela formação de consórcios públicos, tal como autoriza o art. $241^{56}$ da Constituição, com a redação que lhe deu a Emenda Constitucional n. ${ }^{\circ}$ 19, regulamentado pela Lei 11.107/05, sendo desnecessária a atuação do Estado federado nesse tocante.

(ii) $\mathrm{O}$ art. 43, por sua vez, é mais incisivo em seus propósitos; ele faculta à União a "articular sua ação em um mesmo complexo geoeconômico e social, visando a seu desenvolvimento e à redução das desigualdades regionais". O que vale ressaltar no dispositivo é o objeto eleito como foco da ação estatal: "complexo geoeconômico e social". Conquanto esse conceito possa ser fluido, reconhece-se nele que não é a geografia física que deve dar identidade à região sobre a qual incidirá a articulação da Administração federal, mas, sim, uma determinada configuração social e econômica circunscrita espacialmente. Na Constituição não se identifica presunção alguma de que uma dada realidade física implique um quadro socioeconômico que obrigue a ação governamental. Mas o texto constitucional parte do pressuposto de que a configuração da região (no sentido jurídico) a ser criada se deve a uma especial demanda de ação estatal em busca do desenvolvimento local. Desse modo, a lei complementar que a instituir deve dispor sobre:

"I - as condições para integração de regiões em desenvolvimento"; isto é, uma vez que se trata de regiões em desenvolvimento, obviamente que a finalidade precípua do instituto não é prestigiar localidades mais abastadas, mas aquelas que, na letra do

\footnotetext{
56 “Art. 241. A União, os Estados, o Distrito Federal e os Municípios disciplinarão por meio de lei os consórcios públicos e os convênios de cooperação entre os entes federados, autorizando a gestão associada de serviços públicos, bem como a transferência total ou parcial de encargos, serviços, pessoal e bens essenciais à continuidade dos serviços transferidos."
} 
dispositivo, parecem sofrer de alguma forma de isolamento dos outros "complexos geoeconômicos e sociais" que implique um nível de desenvolvimento menor do que o do seu entorno;

“II - a composição dos organismos regionais que executarão, na forma da lei, os planos regionais, integrantes dos planos nacionais de desenvolvimento econômico e social, aprovados juntamente com estes". A necessidade de atenção especial para determinado complexo geoeconômico também seria a razão de um arranjo institucional específico por parte das entidades federais, eventualmente criando uma nova figura administrativa (ou organismo regional). Também a situação peculiar das diferentes circunscrições reclamaria um plano de ação estatal próprio, que se integraria aos planos nacionais. Ou seja, do texto constitucional infere-se que, de alguma forma, o desenvolvimento regional é dependente da ação do Estado brasileiro expresso no plano nacional. Isso também transparece no regime constitucional de elaboração das peças orçamentárias $^{57}$ e nas disposições que tratam do planejamento no âmbito da ordem econômica constitucional ${ }^{58}$. O conteúdo desses planos regionais, a Constituição não estabelece, mas o $\S 2^{\circ}$ do art. 43 denota uma vinculação presumida entre a busca do desenvolvimento local e o emprego de mecanismos de incentivo à atividade econômica. É nítido, ao menos nos inc. I a III, que a solução pensada para a questão regional passa principalmente pela promoção das forças produtivas na medida em que se estabelece que “[o]s incentivos regionais compreenderão, além de outros, na forma da lei, I - igualdade de tarifas, fretes, seguros e outros itens de custos e preços de responsabilidade do poder público"; "II - juros favorecidos para financiamento de atividades prioritárias"; "III isenções, reduções ou diferimento temporário de tributos federais devidos por pessoas físicas ou jurídicas". Veja-se que esses dispositivos tratam de medidas de fomento à atividade produtiva.

Apesar de não ser um traço explícito do modelo, pode-se afirmar que a atuação regionalizada da Administração federal favorece as articulações de maior escala, aplicáveis

\footnotetext{
57 “Art. 165. Leis de iniciativa do Poder Executivo estabelecerão: (...) $\S 1^{o}$ - A lei que instituir o plano plurianual estabelecerá, de forma regionalizada, as diretrizes, objetivos e metas da administração pública federal para as despesas de capital e outras delas decorrentes e para as relativas aos programas de duração continuada". (Grifamos)

58 "Art. 174. Como agente normativo e regulador da atividade econômica, o Estado exercerá, na forma da lei, as funções de fiscalização, incentivo e planejamento, sendo este determinante para o setor público e indicativo para o setor privado. $\S 1^{o}$ - A lei estabelecerá as diretrizes e bases do planejamento do desenvolvimento nacional equilibrado, o qual incorporará e compatibilizará os planos nacionais e regionais de desenvolvimento". (Grifamos)
} 
a porções do território mais extensas. Até porque, vê-se que não é absolutamente singela a coordenação assumida pelo $\S 1^{\circ}$, de modo que não se justifica uma grande mobilização da estrutura administrativa da União para atender a uma demanda demasiadamente pontual. Isso pode ser feito, de maneira mais eficiente, por políticas estaduais de desenvolvimento regional. A formulação do art. 43 da Constituição parece se prestar, pois, a abarcar regiões de maior dimensão geográfica, contemplando uma pluralidade de municípios em mais de um Estado da federação. Não é sem motivo, pois, que, até o momento, as seis regiões criadas são formadas por dezenas de municípios e/ou a totalidade do território de alguns Estados $^{59}$.

(iii) Há ainda um outro significado para o vocábulo "região" que é relevante para fins de determinação da amplitude geográfica da ação estatal. Nos artigos 159, I, c ${ }^{60}$ e 34, $\S 10^{61}$ do ADCT, que tratam da repartição de receitas de impostos federais, e no $42^{62}$ dos ADCTs, "Região" designa as clássicas divisões do território brasileiro em cinco grandes agregados (macroregiões). A diferenciação entre Sul, Sudeste, Centro-Oeste, Nordeste e Norte $^{63}$ permite a instituição de mecanismos de canalização de recursos para as três últimas, na forma da constituição de fundos especialmente voltados ao financiamento ${ }^{64}$.

\footnotetext{
59 1. A Região Integrada de Desenvolvimento do Distrito Federal e Entorno (Lei Complementar 94/98), é constituída pelo Distrito Federal, por 20 municípios goianos e 2 municípios mineiros; 2. A Região Integrada de Desenvolvimento da Grande Teresina (Lei Complementar 112/01) é constituída por 14 municípios do Piauí e por 1 município maranhense; 3. A Região Administrativa Integrada de Desenvolvimento do Pólo Petrolina/PE e Juazeiro/BA, (Lei Complementar 113), é constituída por 5 municípios pernanbucanos e quatro baianos; 4. A Região do Desenvolvimento do Centro-Oeste - SUDECO (Lei Complementar 129/09) compõe-se dos Estados de Mato Grosso, Mato Grosso do Sul e Goiás e o Distrito Federal; 5. A área da SUDAM (Lei Complementar 124) abrange os Estados do Acre, Amapá, Amazonas, Mato Grosso, Rondônia, Roraima, Tocantins, Pará e do Maranhão na sua porção a oeste do Meridiano 44º 6 . Já a área de competência da SUDENE (Lei Complementar 125) abarca os Estados do Maranhão, Piauí, Ceará, Rio Grande do Norte, Paraíba, Pernambuco, Alagoas, Sergipe, Bahia e mais 56 municípios mineiros e 10 municípios capixabas.

60“Art. 159. A União entregará: I - do produto da arrecadação dos impostos sobre renda e proventos de qualquer natureza e sobre produtos industrializados quarenta e oito por cento na seguinte forma: (...) c) três por cento, para aplicação em programas de financiamento ao setor produtivo das Regiões Norte, Nordeste e Centro-Oeste, através de suas instituições financeiras de caráter regional, de acordo com os planos regionais de desenvolvimento, ficando assegurada ao semi-árido do Nordeste a metade dos recursos destinados à Região, na forma que a lei estabelecer";

61 "Art. 34 (....) § 10 - Enquanto não entrar em vigor a lei prevista no art. 159, I, "c", cuja promulgação se fará até 31 de dezembro de 1989, é assegurada a aplicação dos recursos previstos naquele dispositivo da seguinte maneira: I - seis décimos por cento na Região Norte, através do Banco da Amazônia S.A.; II - um inteiro e oito décimos por cento na Região Nordeste, através do Banco do Nordeste do Brasil S.A.;III - seis décimos por cento na Região Centro-Oeste, através do Banco do Brasil S.A".

62 “Art. 42. Durante 25 (vinte e cinco) anos, a União aplicará, dos recursos destinados à irrigação: I - vinte por cento na Região Centro-Oeste; II - cinqüenta por cento na Região Nordeste, preferencialmente no semiárido."

${ }^{63}$ Essa distinção consta do Decreto n. ${ }^{\circ} 67.647 / 1970$.

${ }^{64}$ Os recursos a que se refere o art. 159, I, c são depositados no Fundo Constitucional de Financiamento do Norte - FNO, no Fundo Constitucional de Financiamento do Nordeste - FNE e no Fundo Constitucional de Financiamento do Centro-Oeste - FCO, criados pela Lei 7.829/89.
} 
Disso se conclui que há uma espécie de escala geográfica implícita na atuação regionalmente focada da União como instrumento de desenvolvimento local. Trata-se de uma escala macro, que leva em consideração grandes extensões do território. Não se está colocando em questão a utilidade de referências como as macrorregiões brasileiras tampouco a instituição de regiões federais. Elas têm sua razão de ser na medida em que identificam espaços cuja identidade se funda em características sócio-econômicas que são notadamente distintas dos demais.

Todavia, a atuação em escala macro talvez esse não seja o mecanismo mais adequado para atingir os propósitos de uma política de desenvolvimento produtivo que dê especial atenção ao desenvolvimento local, assim entendida essa referência geográfica como uma escala significativamente menos extensa. Isso porque escalas regionais mais extensas acabam por abarcar diferenças intra-regionais significativas, e é possíve mesmo que os desequilíbrios entre localidades no interior da região impliquem a concentração de recursos em núcleos muito restritos de crescimento econômico e, por conseguinte, o agravamento da situação das demais áreas ${ }^{65}$.

As políticas em escala micro podem ser até menos exigentes e demandar uma atuação menos sofisticada, ou, ao contrário, reclamar medidas por demais diversificadas, mas que não exijam uma permanência por um lapso temporal tão extenso que justifique criar uma entidade administrativa. Assim é que se tem de pensar numa escala de atuação da União que viabilize sua atuação em áreas menos extensas que as de magnitude normalmente pressuposta na criação de regiões nos termos do art. $43^{66}$. Certo é que, no plano das políticas estaduais, a ideia de microrregião parece se coadunar a um padrão de intervenção mais localizado. Mas isso não deve significar, todavia, que a União, que tem um fundamental papel na redução das desigualdades regionais, deixe de atuar. A igualação

\footnotetext{
65 Para uma descrição minuciosa de como a política regional de desenvolvimento no Brasil acentou desigualdades intra-regionais, ver BERCOVICI, Gilberto. Desigualdades Regionais, Estado e Constituição. São Paulo: Max Limonad, 2003

66 "A valorização de escalas menos abrangentes que as tradicionalmente adotadas deve ser entendida como parte de um processo de ajuste das políticas regionais brasileiras ao novo paradigma dominante na área, que passou a enfatizar a importância da dinâmica interna das regiões - inclusive em termos políticos e sociais - como um elemento determinante do seu potencial de desenvolvimento. A escala macrorregional, tradicionalmente utilizada como referência exclusiva para as ações federais de desenvolvimento regional, ao implicar em territórios excessivamente heterogêneos, dificulta uma adequada mobilização potencial endógeno dos territórios". BANDEIRA, Pedro S. "As Mesorregiões no Contexto da Nova Política Federal de Desenvolvimento Regional: Considerações Sobre Aspectos Institucionais e Organizacionais”. Disponível em http://www.integracao.gov.br/ publicacoes/, pp. 3-4.
} 
das condições de vida pode passar pelo desenvolvimento estimulado de localidades pelas entidades federais.

\subsubsection{Outros parâmetros normativos do conceito de região no Decreto $n^{\circ}{ }^{o} 6.047 / 07$ (Política de Desenvolvimento Regional)}

O Decreto n. ${ }^{\circ}$ 6.047/07 enuncia-se como o veículo da Política Nacional de Desenvolvimento Regional e o faz estabelecendo alguns parâmetros normativos de região, que se coadunam com uma escala geográfica menos abrangente e permitem pensar-se políticas de desenvolvimento produtivo mais focadas e localizadas.Trata-se, portanto, de diploma de inegável importância em razão da matéria de que cuida, mas justamente por isso é de se criticar que se consubstancie num simples Decreto, modificável sem maiores formalidades pelo Presidente da República.

Talvez uma política de tal pretensão merecesse uma estrutura institucional mais estável, o que se conseguiria caso houvesse edição de lei tratando desse objeto. O fundamento do Decreto n. ${ }^{\circ} 6.047 / 2007$ é a Lei n. ${ }^{\circ}$ 10.683/03, que organiza os Ministérios da União e, nesse sentido, atribui a competência de "formulação e condução da política de desenvolvimento nacional integrada"(art. 27, XII, a), "formulação dos planos e programas regionais de desenvolvimento (art. 27, XII, b) ao Ministério da Integração Nacional ${ }^{67}$.

Em relação ao seu conteúdo, o diploma se vale de três referências de escala espacial: a macrorregião, a mesorregião diferenciada - escala para a qual se dá preferência - e as regiões integradas de desenvolvimento (a "região" administrativa do art. 43 da Constituição da República), sem prejuízo de outros espaços subregionais que possam vir a ser considerados pelo Ministério da Integração Nacional ${ }^{68}$.

\footnotetext{
${ }^{67} \mathrm{O}$ fato de o Decreto visar precipuamente a sistematização da ação dministrativa federal em relação ao tema, sem estabelecer novos instrumentos ou entidades, explica a dispensa da Lei; note-se que o diploma regulamentar invoca como motivo de sua edição o art. 84, VI, da Constituição da República, o qual permite ao Presidente da República dispor, mediante Decreto, sobre a "organização e funcionamento da administração federal, quando não implicar aumento de despesa nem criação ou extinção de órgãos públicos".

68 "Art. $3^{\circ}$ A PNDR comportará a definição de estratégias de desenvolvimento regional nas escalas seguintes: I - na escala macrorregional, deverão ser elaborados Planos Estratégicos de Desenvolvimento, atendendo ao disposto no inciso IX do art. 21 da Constituição, com prioridade para as regiões Norte, Nordeste e Centro-Oeste, cujas elaboração e implementação serão coordenadas pelas instituições responsáveis pelo desenvolvimento das respectivas áreas de abrangência, sob orientação do Ministério da Integração Nacional; e II - na escala sub-regional, o Governo Federal atuará, prioritariamente, por meio de seus Programas, em escala mesorregional, considerada a definição de Mesorregiões Diferenciadas proposta
} 
A ideia de mesorregião diferenciada - o espaço subnacional contínuo menor que o das macrorregiões, existentes ou em proposição, com identidade comum, que compreenda áreas de um ou mais Estados da Federação, definido para fins de identificação de potencialidades e vulnerabilidades que norteiem a formulação de objetivos socioeconômicos, culturais, político-institucionais e ambientais (art. $3^{\circ}, \S 5^{\circ}$ ) - parece ser um bom instrumento para as políticas federais, na medida em que permite instituir planos de ação em escala compatível com as dos problemas de desenvolvimento econômico de abrangência terrotorial mais restrita.

No entanto, essa noção carrega uma dificuldade de aplicação: a necessidade de se encontrar um elemento de identificação do espaço mesorregional, isto é, que sejam ressaltados caracteres econômicos e sociais que ensejem uma política pública organizada tendo em vista o desenvolvimento de uma determinada área ${ }^{69}$. Talvez isso explique o fato de que, atualmente, o que se tem tomado por mesorregião corresponda a porções territoriais tão extensas e reúna contingentes populacionais tão expressivos, que é difícil adotar políticas mais focalizadas de modo eficiente. Nessa perspectiva, portanto, uma política de promoção dos APLs não poderia se pautar em tal escala, mas somente estar compreendida num plano de ação que tivesse como objeto uma dada mesorregião, dado que algumas medidas de apoio aos APLs não precisam ter grande magnitude ${ }^{70}$.

pelo Ministério da Integração Nacional e aprovada pela Câmara de Políticas de Integração Nacional e Desenvolvimento Regional, criada pelo Decreto $n^{\circ} 4.793$, de 23 de julho de 2003. $\$ 1^{\circ}$ O Ministério da Integração Nacional, mediante portaria, poderá definir os limites territoriais das Mesorregiões Diferenciadas e outros espaços sub-regionais. $\S 2^{\circ}$ A definição dos limites territoriais das Mesorregiões Diferenciadas, bem assim de outros espaços sub-regionais de que trata o parágrafo anterior serão ratificados pela Câmara de Políticas de Integração Nacional e Desenvolvimento Regional, observados os critérios da tipologia da PNDR, constante no Anexo II deste Decreto. (...) $\$ 5^{\circ}$ Para fins deste Decreto e, especialmente, do disposto no inciso II do caput deste artigo, entende-se por Mesorregião Diferenciada o espaço subnacional contínuo menor que o das macrorregiões, existentes ou em proposição, com identidade comum, que compreenda áreas de um ou mais Estados da Federação, definido para fins de identificação de potencialidades e vulnerabilidades que norteiem a formulação de objetivos socioeconômicos, culturais, político-institucionais e ambientais. $\S 6^{\circ}$ Para efeito do disposto no $\$ 4^{\circ}$ deste artigo, entende-se como: I Faixa de Fronteira, os espaços compreendidos em até cento e cinqüenta quilômetros de largura, ao longo das fronteiras terrestres, conforme estabelecido no $\$ 2^{\circ}$ do art. 20 da Constituição; e II - Região Integrada de Desenvolvimento, o complexo geoeconômico e social, conforme estabelece o art. 43 da Constituição."

${ }^{69}$ Pedro S. BANDEIRA sugere os seguintes critérios: "a) a delimitação deve basear-se na identificação de redes de articulação regional já existentes; b) devem ser aproveitados elementos simbólicos capazes de contribuir para a formação ou para o fortalecimento de uma identidade da região; c) A abrangência territorial da região deve ser definida de modo a assegurar que seja alcançado um patamar mínimo de densidade institucional". Vide "As Mesorregiões no Contexto da Nova Política Federal de Desenvolvimento Regional: Considerações Sobre Aspectos Institucionais e Organizacionais”. Disponível em http://www.integracao.gov.br/ publicacoes/, p. 18.

${ }^{70}$ Nesse sentido: "Um dos maiores desafios para uma coordenação consistente e sistemática de políticas com repercussões territoriais é a definição de áreas geográficas de intervenção (AGI), que delimitem claramente ao nível territorial e os pontos de interseção das políticas públicas. Ou seja, as AGI compreenderiam as diversas escalas territoriais numa progressão do local ao nacional de forma a 


\subsubsection{Entidades federais e o desenvolvimento produtivo regional}

A execução das políticas federais de desenvolvimento regional cujos fundamentos foram expostos acima é distribuída entre algumas entidades administrativas.

Ao Ministério da Integração Nacional (MIN) cabe, em linhas gerais, a formulação de políticas públicas atinentes à área. Isso se concretiza principalmente na formulação de planos e programas de desenvolvimento regional e na fixação das diretrizes de funcionamento dos fundos de desenvolvimento regional ${ }^{71}$, os fundos fiscais de investimento (Finam, Finor e Funres ${ }^{72}$.

Vinculadas ao Ministério, mas dotadas de relativa autonomia, estão a SUDENE, SUDECO e SUDAM, autarquias encarregadas de executar a política federal de desenvolvimento nas respectivas Regiões administrativas ${ }^{73}$. Essas entidades operam de

identificar tais pontos aos níveis micro, meso e macro-espacial. Exemplos típicos das AGI ao nível micro seriam as interseções de políticas de desenvolvimento local (voltado para a infraestrutura urbana e a estrutura produtiva, como os APLs) e as políticas setoriais universais (como saúde, educação e segurança alimentar). Ao nível meso seriam as políticas cujo foco de intervenção é o espaço região, que integra espaços locais contíguos nas esferas da produção, distribuição e consumo. As interseções clássicas ao nível meso são entre as políticas industrial (cadeias e complexos produtivos espaciais), regional (complementaridade produtiva intra-regional e rede urbana regional) e de infra-estrutura intermediária (sub-sistema regional de transportes, saneamento de sub-bacias hidrográficas, etc.). Por fim, as interseções ao nível macro-espacial, que integram regiões contíguas em escala sub-nacional acima de uma Unidade Federativa, são atinentes às políticas de integração do território nacional visando a integração do mercado interno e a sua vinculação ao mercado sub-continental e global, como as políticas nacionais de transporte de carga, de energia e telecomunicações". LEMOS, Mauro Borges. "Regionalização: análise da experiência brasileira recente". Relatório do Projeto Diretrizes para Formulação de Políticas de Desenvolvimento Regional $e$ de Ordenação do Território Brasileiro. Disponível em: http://www.integracao.gov.br/publicacoes/desenvolvimentoregional/publicação, p. 2.

71 O Art. 27, XIII da Lei 10.683/03 arrola a competência do Ministério da Integração Nacional: “a) formulação e condução da política de desenvolvimento nacional integrada; $b$ ) formulação dos planos $e$ programas regionais de desenvolvimento; c) estabelecimento de estratégias de integração das economias regionais; d) estabelecimento das diretrizes e prioridades na aplicação dos recursos dos programas de financiamento de que trata a alínea c do inciso I do art. 159 da Constituição Federal; e) estabelecimento das diretrizes e prioridades na aplicação dos recursos do Fundo de Desenvolvimento da Amazônia e do Fundo de Desenvolvimento do Nordeste; f) estabelecimento de normas para cumprimento dos programas de financiamento dos fundos constitucionais e das programações orçamentárias dos fundos de investimentos regionais; g) acompanhamento e avaliação dos programas integrados de desenvolvimento nacional. (...)". Já o art. 14-A da Lei 7.827/89 prescreve que "Cabe ao Ministério da Integração Nacional estabelecer as diretrizes e orientações gerais para as aplicações dos recursos dos Fundos Constitucionais de Financiamento do Norte, Nordeste e Centro-Oeste, de forma a compatibilizar os programas de financiamento com as orientações da política macroeconômica, das políticas setoriais e da Política Nacional de Desenvolvimento Regional".

72 O Finam e o Finor (criados pelo Decreto-Lei 1.376/74) estão fechados para novos projetos (vide Medida Provisória 2.146-1) já o Funres (instituído pelo Decreto-Lei 889/69) ainda opera, contando com recursos e incentivos fiscais do Estado do Espírito Santo. Para um histórico sobre o Finor e os problemas que levaram à sua extinção, ver CAMPOS, Hélio S. Ourem . "O Finor e o desenvolvimento do Nordeste - processos de distribuição e de concentração de renda”. Prisma Jurídico, v. 7, , 2008, p. 1-22.

${ }^{73}$ Essas entidades foram recentemente recriadas, depois de terem sido extintas e, no caso da SUDENE e da SUDAM, substituídas pela Agência de Desenvolvimento do Nordeste (ADENE) e Agência de Desenvolvimento da Amazônia (ADAM), respectivamente. A principal característica do atual modelo das 
maneira homóloga em relação aos objetivos de desenvolvimento produtivo, cada uma em sua área de atuação. Em suma, elas têm como missão incentivar projetos de investimento nas áreas em que atuam ${ }^{74}$, o que fazem com o suporte financeiro dos fundos constitucionais de financiamento a que alude o art. 159, I, c, da Constituição da República e instituídos pela Lei 7.829/89 (FCO, FNE e FNO) ${ }^{75}$. Além disso, contam com os Fundos de Desenvolvimento do Nordeste, do Centro-Oeste e da Amazônia. Cada uma dessas entidades foi (re)criada mediante a edição de Lei Complementar ${ }^{76}$ que definiu a área de atuação, vinculou-lhes a gestão dos fundos acima aludidos e estabeleceu um banco público federal para atuar como agente financeiro ${ }^{77}$.

Também vinculada ao Ministério da Integração, a Companhia de Desenvolvimento do Vale do São Francisco é uma empresa pública que promove ações no Vale do Rio São Francisco e no Vale do Rio Parnaíba, principalmente as ligadas à aquicultura e à produção agrícola (infra-estrutura de irrigação e assistência aos produtores).

O BASA e o BNB também podem ser considerados como entidades voltadas ao desenvolvimento regional, porque eles têm sua operação restrita a uma determinada área, na qual figuram como agentes financeiros dos fundos administrados pela SUDAM e SUDENE, respectivamente, bem como disponibilizam diversas linhas de crédito em apoio a projetos de interesse local $^{78}$.

\footnotetext{
agências é o encerramento dos mecanismos de renúncia fiscal e da operação do Finor e da Finam, de modo que as entidades passaram a atuar tão-somente com recursos oriundos do orçamento da União, por intermédio dos então recém-criados FDNE e FDAM - confira-se PACHECO MOREIRA, Claudia Cristina. "A extinção da SUDAM e da SUDENE”. Revista de Informação Legislativa. Disponível em http://www.buscalegis.ufsc.br/revistas/index.php/buscalegis/article/viewFile/26847/26410.

${ }^{74}$ Veja-se, na seqüência, o que dispõem as Leis Complementares, 124, 125 e 129: "Art. $3^{\circ}$ A SUDAM tem por finalidade promover o desenvolvimento includente e sustentável de sua área de atuação e a integração competitiva da base produtiva regional na economia nacional e internacional"; "Art. $3^{\circ}$ A SUDENE tem por finalidade promover o desenvolvimento includente e sustentável de sua área de atuação e a integração competitiva da base produtiva regional na economia nacional e internacional."; "Art. $3^{\circ}$ A Sudeco tem por finalidade promover o desenvolvimento regional, de forma includente e sustentável, e a integração competitiva da base produtiva regional na economia nacional e internacional."

${ }^{75}$ Lei 7.827/89: "Art. $2^{\circ}$ Os Fundos Constitucionais de Financiamento do Norte, Nordeste e Centro-Oeste têm por objetivo contribuir para o desenvolvimento econômico e social das regiões Norte, Nordeste e Centro-Oeste, através das instituições financeiras federais de caráter regional, mediante a execução de programas de financiamento aos setores produtivos, em consonância com os respectivos planos regionais de desenvolvimento".

${ }^{76}$ LC n. $^{\circ}$ 124/07 - SUDAM; LC n. ${ }^{\circ}$ 125/07 - SUDENE; LC n. ${ }^{\circ}$ 129/09 - SUDECO.

${ }^{77}$ BNB para a SUDENE, BASA para a SUDAM; e BB para a SUDECO - vide também art. 16 da Lei 7.827/89.

${ }^{78}$ A atuação do BASA é limitada pela área geográfica da Região Amazônica, e definida no art. $2^{\circ}$ da Lei ${ }^{\circ}$ 5.173, de 27 de outubro de 1966, e art. 45 da Lei complementar $\mathrm{n}^{\circ} 31$, de 11 de outubro de 1977, com as modificações resultantes dos art. 13 e 14 das Disposições Constitucionais Transitórias, de 5 de outubro de 1988. A atuação do BNB, de acordo com a Lei 1.649/52, restringe-se à área do polígono das secas. O estatuto
} 
Há, ainda, outras entidades que, apesar de não terem sido criadas precipuamente para a atuação regional, têm maior capilaridade e também desenvolvem ações tendo em vista o desenvolvimento regional. É de se citar, por exemplo, o Sebrae, a Embrapa e o Banco do Brasil. Essas entidades têm desenvolvido projetos em escala local, razão pela qual são bastante presentes em APLs por todo o país ${ }^{79}$. Em comum, todas essas entidades têm a missão de induzir os agentes privados a atuarem em prol do desenvolvimento produtivo. Elas manejam mecanismos que incentivam a adoção de determinadas condutas que, em princípio, colaborariam com o alcance do robustecimento da estrutura produtiva nacional e regional.

\subsection{Conclusão Parcial}

Este capítulo se destinou a apresentar a ideia de que se pode encontrar, na Constituição da República, uma missão conferida ao Estado brasileiro que entrelaça a busca pela superação da condição do subdesenvolvimento e com a redução das desigualdades regionais. Igualação das condições de vida e o desenvolvimento produtivo nacional são objetivos que se imbricam. Espera-se que esses tópicos iniciais tenham demonstrado duas coisas. A primeira, que a noção de "região" pode dar ensejo a políticas de escalas distintas; a segunda, que as estratégias das políticas de desenvolvimento produtivo podem se guiar por diversos critérios normativos, de acordo com diversos matizes no espectro ideológico que vai da defesa da intervenção mínima e horizontalizada do Estado até a sugestão da ação agressiva e mesmo setorializada do poder público.

Assim é que se pode concluir que o fomento aos APLs não decorre necessariamente do nosso modelo constitucional, mas se mostra como uma opção de política pública que se preste a conjugar, por definição, o estímulo ao setor produtivo e o desenvolvimento local. Nem mesmo a forma pela qual se dá a promoção dos Arranjos

do banco estabelece que as áreas de atuação são a região nordeste do país e a região norte dos Estados de Minas Gerais e Espírito Santo.

79 Apesar de ainda não existirem estudos sobre o tema, pode-se dizer que o fato de essas entidades possuírem unidades regionais dotadas de razoável autonomia contribui para que elas desenvolvam programas de escala regional e local. 
Produtivos Locais é sequer sugerida de antemão pela Constituição. Portanto, subsiste um espaço decisório amplo para a formatação das políticas de incentivo.

Todavia, em princípio, pode-se assumir a ideia de que podem co-existir diferentes racionalidades de políticas de fomento dos APLs: medidas horizontalizadas, aplicáveis a quaisquer Arranjos, de um modo geral, mas que não eliminam, contudo, intervenções pontuais. Até porque, por definição, mesmo as medidas horizontalizadas, na medida em que beneficiam região e setores específicos, podem ser entendidas como intervenção focalizada.

E vale ressaltar aqui uma premissa que restou subjacente em todo o texto até aqui exposto: a promoção dos APLs, como, de todo, os marcos principais das políticas de desenvolvimento regional e mesmo os modelos teóricos de políticas industriais aqui discutidos atribuem um papel considerável à iniciativa privada. Por mais que a definição do sentido geral das espécies de políticas aqui mencionadas seja uma missão estatal, fato é que não se assume que o desenvolvimento produtivo regional seja realizado sem o robustecimento das forças de mercado. O desafio principal, pois, é fazer essas forças exsurgirem e operarem de modo a contribuir com o objetivo estabelecido no art. $3^{\circ}$ da Constituição da República. E há os instrumentos que possibilitem essa tarefa.

O que se pretende fazer no capítulo a seguir é dar um panorama dos institutos jurídicos de que o Estado dispõe para estimular a atividade econômica e, concomitantemente, ordená-la. Ao tratar dos mecanismos de fomento, procuraremos dar exemplos de sua utilização em prol dos APLs. 


\section{CAPÍtULO 2}

\section{A ATIVIDADE ESTATAL DE INCENTIVO (FOMENTO ESTATAL)}

A atividade de fomento não é tratada de maneira uniforme e sistemática pelo ordenamento jurídico. Contudo, isso não se deve a uma falha dos nossos órgãos Legislativos, mas à presença quase que totalizante das normas de política econômica na vida social ${ }^{80}$, as quais se valem grandemente de mecanismos de incentivo de toda sorte. $\mathrm{O}$ fomento é uma técnica regulatória que incide sobre os mais diversos aspectos da produção e circulação de bens. Este capítulo tem a intenção de somente apresentar uma pequena fração de alguns mecanismos pelos quais ela pode se concretizar, buscando fazer um breve mapa da tradução jurídica dos mecanismos das políticas de desenvolvimento produtivo.

\subsection{ASPECTOS GERAIS DA ATIVIDADE DE INCENTIVO (FOMENTO)}

\subsubsection{O art. 174 da Constituição da República}

A Constituição da República não tem muitas palavras para a atividade de fomento. O enquadramento constitucional dessa forma de atuação do Estado na economia se dá na letra do caput do art. $174^{81}$, dispositivo que é a principal matriz jurídica da atividade normativa do Estado na política econômica, pois sua redação é suficientemente genérica para amparar praticamente qualquer medida nessa seara. $\mathrm{O}$ caput do art. 174 estabelece que a função de incentivo se dará a título de atuação normatizadora e reguladora do Estado. Fomento, pois, tem a ver com a competência de tutela da ordem econômica; é uma técnica

\footnotetext{
${ }^{80}$ Se o ordenamento jurídico é um instrumento de regulação dos bens da vida, e estes, quase que em sua totalidade, inserem-se no mundo do mercado, então praticamente não há aspecto da vida que não diga respeito à tutela da economia e, pois, não se submeta à regulação jurídica. Obviamente que esse argumento pressupõe uma teoria do conteúdo do ordenamento jurídico, cujo desenvolvimento ultrapassa os limites deste trabalho, mas pode-se assumir que a enorme amplitude dos fatos econômicos (aqui entendidos como tudo o que diz respeito à produção e circulação de riqueza) passíveis de serem tomados como objetos de normatização impede que se busque em poucos diplomas legais ou regulamentares o que o ordenamento apresenta sobre o fomento (ou, para usar a terminologia constitucional, incentivo).

81 “Art. 174. Como agente normativo e regulador da atividade econômica, o Estado exercerá, na forma da lei, as funções de fiscalização, incentivo e planejamento, sendo este determinante para o setor público e indicativo para o setor privado."
} 
que visa infuenciar e conformar a ação dos agentes econômicos - mas de um modo peculiar: não se apresenta aqui o atributo da cogência do comportamento visado pelo ordenamento jurídico, mas, diversamente, o Estado apenas aponta para uma direção e favorece as condutas dos particulares que se coadunem com tal objetivo ${ }^{82}$. Tem-se, aqui, pois, o que Eros ROBERTO GRAU denomina de "atuação estatal no domínio econômico por indução" "83; ou o que Fábio Konder COMPARATO denominou "relações de economia mista" ${ }^{\text {" }}$, predicadas que são pelo estabelecimento de objetivos pelo Estado e pela concessão de vantagens aos particulares, para que estes, atuando conforme seus próprios interesses, possam alcançar tais objetivos. Nesse sentido, Célia Cunha MELLO consigna que o "fomento público nao é imposto à sociedade, sendo facultativa a relação jurídicoadministrativa, sendo o administrado livre para aderir a objetivos de interesse público (...) ${ }^{, 85}$. Para Carlos ARI SUNDFELD, "o fomento estatal à vida privada consiste na concessão de benefícios aos particulares, de modo a induzir suas ações em certo sentido. Quem não se dispõe a adotar o comportamento pretendido não é sancionado; apenas deixa de usufruir o benefício que teria, em caso contrário" ${ }^{\# 6}$. O Estado, então, não impõe

\footnotetext{
${ }^{82}$ Eros Roberto GRAU trata da natureza das normas indutoras. "No caso das normas de intervenção por indução, defrontamo-nos com preceitos que, embora prescritivos (deônticos), não são dotados da mesma carga de cogência que afeta as normas de intervenção por direção. Trata-se de normas dispositivas. Não, contudo, no sentido de suprir a vontade de seus destinatários, porém, na dicção de Modesto Carvahosa, no de 'levá-lo a uma opção econômica de interesse coletivo e social que transcende os limites do querer individual'. Nelas, a sanção, tradicionalmente manifestada como comando, é substituída pelo expediente do convite -ou, como averba Washington Peluso Albino de Souza-de 'incitações, dos estímulos, dos incentivos, de toda ordem, oferecidos, pela lei, a quem participe de determinada atividade de interesse geral e patrocinada, ou não, pelo Estado'. Ao destinatário da norma resta aberta a alternativa de não se deixar por ela seduzir, deixando de aderir à prescrição nela veiculada. Se adesão a ela manifestar, no entanto, resultará juridicamente vinculado por prescrições que correspondam aos benefícios usufruídos em decorrência dessa adesão" em A Ordem Econômica na Constituição de 1988: Interpretação e Crítica. São Paulo: Revista dos Tribunais, 2008, 13 a ed., p. 148-149. No campo da teoria dogmática, essa manifestação do ordenamento foi muito destacada pelos autores que tratam da função premial do Direito. Cf. Norberto BOBBIO. Da Estrutura à Função. Sâo Paulo: Manole, 2007.

${ }^{83}$ Calha aqui a categorização formulada por Eros ROBERTO GRAU, segundo a qual o Estado atua no domínio econômico mediante; (i) participação, assumindo o controle de parcela do mercado, atuando como agente fornecedor de bens e serviços; (ii) direção, impondo condutas de forma coercitiva aos agentes regulados; e (iii) por indução, manejando os aparatos de intervenção conforme em termos correlatos aos que se observam no mercado Na ação fomentadora, as normas por indução prevalecem e condicionam. Em sentido semelhante, Carlos Ari SUNDFELD propõe uma divisão do estudo do Direito Administrativo que se coaduna com essa categorização: direito administrativo ordenador; direito administrativo prestacional e direito administrativo fomentador, em Direito Administrativo Ordenador, São Paulo: Malheiros, 2003, pp. $16-17$.

${ }^{84}$ COMPARATO, Fábio Konder. O Indispensável Direito Econômico. Revista dos Tribunais, vol. 353, 1965, pp. 453-472.

${ }^{85}$ MELLO, Célia Cunha. O Fomento da Administração Pública. Belo Horizonte: Del Rey, 2003, p. 84.

${ }^{86}$ Direito Administrativo Ordenador, São Paulo: Malheiros, 2003, p. 25. Em sentido semelhante à conceituação de Luis Jordana POZAS: “(....) a ação da Administração destinada a proteger ou promover aquelas atividades, estabelecimentos ou riquezas prestadas por particulares e que satisfazem necessidades
} 
uma conduta, mas oportuniza sua prática mediante o oferecimento de algumas atrativos de conteúdo econômico. É uma forma de direcionar a atuação do particular a um objetivo de política pública. Diogo MOREIRA NETO, por sua vez, define o fomento público como:

função administrativa através da qual o Estado ou seus delegados estimulam ou incentivam, direta, imediata e concretamente, a iniciativa dos administrados ou de outras entidades públicas e privadas, para que estas desempenhem ou estimulem, por seu turno, as atividades que a lei haja considerado de interesse público para o desenvolvimento integral e harmonioso da sociedade ${ }^{87 .}$

Dois comentários a respeito dessa conceituação. O primeiro: não há por que considerar que os incentivos estatais se concretizem apenas por intermédio da ação administrativa, pois a norma de incentivo pode decorrer diretamente da lei; se isso não faz prescindir a atuação da Administração, por certo inclui o Legislativo no quadro de atores que manejam os instrumentos de fomento, haja visto o princípio da legalidade que rege a atividade administrativa (art. 37, caput da Constituição da República). O segundo comentário: é de se notar que não somente aos agentes privados podem ser direcionadas ações de fomento, mas também ao próprio poder público. Onde quer que haja um fluxo de recursos públicos pode haver o emprego de mecanismos que funcionem segundo a lógica do fomento. Assim é que, a pretexto do repasse voluntário de verbas ${ }^{88}$ de um ente federativo para outro ou, então, quando da concessão de financiamentos pelas instituições financeiras estatais ${ }^{89}$, podem ser identificados instrumentos de indução de condutas que têm entidades públicas como destinatárias.

Contudo, o que talvez não esteja devidamente explicitado nas definições formuladas acima é a natureza do incentivo estatal: trata-se de um benefício de valor econômico, financeiramente mensurável, ainda que ele não assuma a forma de recurso financeiro (a prestação de serviços de assistência técnica pela Administração a titulo gratuito, por exemplo).

O Estado proporciona ao particular algo apto a repercutir consequências na organização e nos resultados da atividade econômica. Isto é, presume-se que, sem o

públicas ou se consideram de utilidade geral, sem usar a coação ou criar serviços públicos" em "Ensayo de una teoria del fomento en el Derecho Administrativo". Revista de Estudios Políticos, n. 48, p. 46, 1949.

${ }^{87}$ Curso de Direito Administrativo, Rio de Janeiro: Forense, $14^{\text {a }}$ ed, p. 525.

${ }^{88}$ Da União para Estados e Municípios, bem como dos Estados para os seus Municípios.

${ }^{89}$ É de se lembrar que os bancos da União têm programas de financiamento que atendem a Estados e Municípios. 
incentivo, determinada atividade seria exercida em condições mercadológicas diferentes ${ }^{90}$, ou mesmo não seria sequer desempenhada porquanto inviável. A atuação estatal pode se dar tanto na promoção da demanda, assegurando mercado para determinados produtos e garantindo a subsistência de setores especialmente sensíveis às oscilações de procura, bem como no estímulo da oferta, incentivando os próprios produtores, franqueando-lhes os recursos e instrumentos que se entendam necessários ao desenvolvimento de determinada atividade.

Pode-se afirmar, pois, que o fomento tem o propósito de construção e fortalecimento de mercados mediante a viabilização de determinadas condutas, ainda que, em alguns casos, privilegiar um comportamento implique desprestigiar outros que cumpram função semelhante; isso é, o estímulo a produção de bem ou serviço pode fazer com que haja a diminuição da demanda por bem ou serviço que lhe seja substituto. Em alguns casos, essa preferência expressa na política de fomento pode ter mesmo a intenção manifesta de dificultar determinadas práticas e deprimir alguns mercados: imagine-se, por exemplo, um conjunto de incentivos em prol do desenvolvimento de biocombustíveis que tenha o condão de viabilizar o mercado desse bem, e, eventualmente, barateá-lo, fazendo com que diminua a demanda por combustíveis fósseis (pressupondo-se a permanência da demanda total por combustíveis). Como ressalta Célia Cunha MELLO:

os meios de fomento podem ser 'positivos', quando conferem prestações, bens ou vantagens, visando facilitar indiretamente a realização de coisas socialmente desejadas, e 'negativos', quando constituem obstáculos ou cargas tendentes a dificultar indiretamente atividades contrárias às que se quer promover ${ }^{91}$.

Ou seja, de fato, a ação estatal fomentadora tem um potencial regulatório significativo, como assumido e ressaltado no art. 174 da Constituição. Ainda que particular algum seja obrigado a anuir a uma conduta fomentada, tal anuência pode advir de uma dada conjuntura mercadológica construída pelos instrumentos de incentivo que o impila a coadunar sua atividade à direção indicada pelo Estado. Convém, então, abordar os limites e as possibilidades da ação fomentadora, o que se fará nos três tópicos subsequientes (2.1.2 a 2.1.4).

\footnotetext{
${ }^{90}$ Por exemplo: um número menor de firmas poderia exercê-la; a instalação das empresas poderia se dar e um ritmo mais lento; o produto resultante da atividade poderia ser mais caro, atingindo um mercado consumidor menor e privando pessoas de seu acesso.

${ }^{91}$ O Fomento da Administração Pública. Belo Horizonte: Del Rey, 2003, p. 182.
} 


\subsubsection{Fomento, subsidiariedade e livre iniciativa}

O primeiro aspecto a se discutir acerca dos limites da ação fomentadora diz respeito à sua intensidade. Noutros termos, isso significa perguntar: até que ponto o Estado pode favorecer um comportamento ou setor da economia em detrimento de outro? Pode-se chegar ao ponto de praticamente inviabilizar práticas e atividades que compitam no mercado com aquelas que o Estado eleja para objeto do fomento? Pode-se aceitar situações limites em que se verifica uma tensão entre a liberdade de iniciativa privada e a discricionariedade das políticas econômicas. É de se destacar, contudo, que a Constituição não estabelece de maneira explícita critério algum no que concerne à intensidade com que o Estado pode se valer de mecanismos de fomento.

Por vezes, a atuação estatal pode ser evidentemente imperiosa e atender um dever cometido ao Estado - a ausência de uma política de crédito agrícola, por exemplo; seria contraditória com a obrigação de zelar pelo abastecimento alimentar ${ }^{92}$; o incentivo, nesse caso, é uma obrigação estatal. Por outro lado, o excesso de incentivo em determinados setores ou atividades (represando capitais no setor beneficiado pelo fomento estatal) pode impedir que atividades concorrentes ou congêneres venham à tona ou subsistam - para ilustrar o argumento, tome-se outro exemplo do setor agrícola: a implantação do Proálcool teve como efeito a redução do plantio de alimentos em algumas regiões, causando elevação do preço desses produtos em algumas localidades. A ação fomentadora, portanto, exige juízos de dosimetria e das consequências que pode acarretar que levem em consideração o estatuto das atividades que pretende prestigiar (ou desprestigiar por via reflexa).

Pode-se ententer que a atividade de fomento é expressão do princípio da subsidiariedade na medida em que, por meio dela, o Estado se desincumbe de explorar diretamente a atividade econômica ${ }^{93}$. De acordo com a ideia da subsidiariedade, a atuação do Estado na exploração de atividade econômica é medida excepcional, só autorizada mediante condições peculiares, isto é, na dicção do caput do art. 173 da Constituição, "quando necessária aos imperativos da segurança nacional ou a relevante interesse coletivo, conforme definidos em lei’. Ou seja, para o poder público a lei representa uma permissão sem a qual sua atuação resta interditada. Para os particulares, a lei tem o condão

\footnotetext{
92 “Art. 23. É competência comum da União, dos Estados, do Distrito Federal e dos Municípios: VIII fomentar a produção agropecuária e organizar o abastecimento alimentar;"

${ }^{93}$ Nesse sentido, TORRES, Silvia Faber. O Princípio da Subsidiariedade no Direito Público contemporâneo. Rio de Janeiro, Renovar, 2001, p. 15.
} 
apenas de interditar ou condicionar a atuação no domínio econômico, ficando a liberdade de iniciativa como regra, pois, na dicção do art. 170, parágrafo único da Constituição, “[é] assegurado a todos o livre exercício de qualquer atividade econômica, independentemente de autorização de órgãos públicos, salvo nos casos previstos em lei”. Haveria, pois, uma distinção entre o regime da autorização pressuposta de atuação (dos particulares) e da atuação direta condicionada à edição de lei (do Estado). Assim é que, em se admitindo que a subsidiariedade é norma na ordem econômica constitucional, a atividade de fomento seria a forma de expressão adequada para que o Estado atuasse na economia.

Todavia, para além da discussão sobre o alcance do caput do art. $173^{94}$ - discussão essa que, principalmente em razão das noções fluidas das hipóteses autorizadoras da atuação do Estado ("quando necessária aos imperativos da segurança nacional ou a relevante interesse coletivo"), dificilmente teria a condição de estabelecer com precisão o campo em que a atuação do Estado seria interditada. Importa aqui perceber que o caráter imperioso do uso dos mecanismos de fomento em favor de diversos setores da economia contradiz a visão da ação fomentadora como algo distante do exercício direto da atividade econômica pelo Estado. A atividade de incentivo pode ter efeitos comparáveis aos da atuação direta.

Em primeiro lugar, porque uma importante modalidade de fomento (se não a mais relevante), a concessão de crédito (e de outros produtos financeiros, como seguro), é ela própria expressão de exercício de atividade econômica. No caso do setor bancário, algumas instituições públicas possuem atuação no varejo, como uma empresa privada, concomitantemente ao oferecimento de linhas de financiamento em condições especiais. Ao exercer a atividade de fomento, o Estado justamente reage à premissa liberal contida na regra da subsidiariedade, segundo a qual a atuação estatal não teria lugar no campo que é próprio da iniciativa privada. Ora, a concessão de crédito é atividade econômica em sentido estrito, na qual os bancos privados podem livremente atuar; mas dificilmente o fazem quando se trata de projetos de maior risco ou de longa maturação. Tem-se o Estado

\footnotetext{
${ }^{94}$ Cf., a esse respeito, BERCOVICI, Gilberto. "Os Princípios Estruturantes e o Papel do Estado". In: José Celso Cardoso Jr. (Org.). A Constituição Brasileira de 1988 Revisitada: Recuperação Histórica e Desafios Atuais das Políticas Públicas nas Áreas Econômica e Social. Brasília: Instituto de Pesquisa Econômica Aplicada, 2009, v. 1, p. 255-291 (onde se argumenta pela inexistência do princípio da subsidiariedade da ação estatal justamente porque os conceitos de relevante interesse coletivo e segurança nacional não se afiguram como impedimentos efetivos à participação estatal na execução de atividades econômicas em sentido estrito) e MARQUES NETO, Floriano de A. "Limites à abrangência e à intensidade da regulação estatal”. Revista de Direito Público da Economia, Belo Horizonte: Fórum, n. 1, jan.-mar. 2003, pp. 69-93 (onde se argumenta que o princípio da subsidiariedade é a baliza para a intensidade da ação estatal).
} 
assumindo verdadeiramente um lugar que, de acordo com a regra da subsidiariedade, não lhe caberia. Isso bem demonstra que é extremamente difícil determinar a seara de atuação do Estado a partir do simples exame abstrato da categoria de atividade econômica em sentido estrito. É a análise fática dos mercados em questão que oportunizará um juízo do cabimento ou necessidade da presença estatal.

Em segundo lugar, porque a atividade fomentadora é de tal forma disseminada e representativa de um suporte decisivo na construção e manutenção de tantos setores da economia (e, no caso do financiamento, no ensejo da fruição de um insumo fundamental às empresas beneficiadas) que não é facultado ao Estado deixar de exercê-lo, sob pena de graves prejuízos à economia nacional. Não é sem razão que, nos últimos anos, as instituições de fomento têm recebido cada vez mais recursos, sendo que, por conta da crise financeira iniciada em 2008, eles foram fundamentais para que o nível da atividade econômica não fosse ainda mais reduzido ${ }^{95}$. O fomento, portanto, não significa necessariamente distância do exercício da atividade econômica, mas, ao contrário, pode ser um instrumento pelo qual o Estado atua de maneira incisiva.

Outra questão relativa ao fomento que se vincula ao valor da livre iniciativa é a possibilidade de se atriuir aos agentes privados, e não ao mercado, os ônus decorrentes das políticas de incentivo. Isto implica perguntar: pode o Estado, ao pretender estimular uma determinada conduta, criar encargos a uma classe de agentes privados em benefício de outra? Essa questão admite resposta a partir de abordagens de diversos graus de generalidade, e todas elas dizem respeito a mecanismos de transferência de recursos de uma determinada categoria de agentes para outra. Assim é que se poderia até mesmo analisar o orçamento público como um grande mecanismo de subsídio cruzado, na medida em que o Estado obtém receita de determinadas atividades econômicas e emprega os recursos auferidos em outras. Num nível de menor generalidade, é essa a discussão presente nos benefícios de meia-entrada ${ }^{96}$, situação em que os empresários e a parcela de consumidores não contemplados com o desconto acabam arcando com os descontos concedidos a determinada categoria de agentes (ex: idosos, estudantes).

\footnotetext{
${ }^{95}$ Em dezembro de 2008, o volume de crédito fornecido pelos bancos públicos correspondia a 13,8\% do PIB, enquanto que os ancos privados respondiam por 16,8\%. Em dezembro de 2009, esses percentuais correspondiam a $18,4 \%$ e $18,2 \%$. Ver o relatório do Banco Central do Brasil intitulado Nota sobre Política Monetária e Operações de Crédito do Sistema Financeiro. Grande parte da expansão pode ser atribuído ao aumento do orçamento do BNDES (mais de 50\% no último ano) realizado por empréstimos do Tesouro Nacional (Lei 11.948/09, autorizou a União a emitir títulos para auferir recursos destinados a conceder crédito ao BNDES).

${ }^{96}$ Assunto tratado no tópico 2.2.8
} 
No julgamento da Ação Direita de Inconstitucionalidade 1.950-3, na qual se discutia a concessão do benefício da meia-entrada a estudantes, o Supremo Tribunal Federal entendeu que o valor da livre iniciativa (consubstanciado, aqui, na liberdade de fixação de preços) não se sobrepõe a outros valores protegidos constitucionalmente (no caso em questão, o acesso à cultura, desporto e educação).

Apesar de o tema do fomento não ter sido debatido de modo mais acentuado, a argumentação presente no julgado permite concluir que não haveria, em princípio, um impedimento absoluto à aplicação de políticas de incentivo que viesse a criar encargos a certa categoria de particulares. No caso discutido, considerou-se que o custo do desconto da meia-entrada seria diluído no preço dos ingressos aplicáveis entre as pessoas que não fazem jus ao benefício.

\subsubsection{Fomento e seleção das atividades beneficiadas}

O incentivo estatal sempre é feito tendo em vista a consecução de um estado de coisas que não se verifica no momento em que é instituído; como qualquer ação estatal, ele tem um sentido transformador ou, ao menos, reativo à uma situação tendente à alteração de um quadro que se entenda aceitável ou proveitoso.

O fomento, portanto, como qualquer outra expressão de política pública, jamais é neutro do ponto de vista axiológico. Ele sempre revela e institui uma preferência por determinado setor, ou conduta em detrimento de outros. Isso remete aos critérios de eleição das atividades, setores e agentes beneficiados: o fomento pode se dar em qualquer setor, ou somente naqueles em que se verifique uma atuação insuficiente do particular? E qual o critério de identificação dessa insuficiência? O Estado pode incentivar só pequenas empresas ou, seria mais eficaz fomentar uma única grande empresa, âncora do mercado, capaz de irradiar efeitos a jusante e a montante na cadeia produtiva?

Também em relação a esses questionamentos não existe uma resposta inequívoca na Constituição da República. Todavia, se o texto constitucional, em matéria de política industrial, não é absolutamente preciso em relação ao conteúdo das atividades que contempla, parece sê-lo em relação à estrutura empresarial digna de proteção. Isto porque o art. 170, IX, estabelece com um dos princípios da ordem econômica constitucional "tratamento favorecido para as empresas de pequeno porte constituídas sob as leis 
brasileiras e que tenham sua sede e administração no País". Além disso, o $§ 2^{\circ}$ do art. 174 prescreve que "[a] lei apoiará e estimulará o cooperativismo e outras formas de associativismo" 97 . A concretização legal desses mandamentos se dá principalmente no Estatuto Nacional da Microempresa e da Empresa Pequena Empresa (Lei Complementar n. ${ }^{\circ}$ 123/06) e na Lei Política Nacional de Cooperativismo (Lei n. ${ }^{o}$ 5.764/71). A expressa menção ao associativismo e às empresas de pequeno porte é especialmente importante para os APLs, podendo ser invocado como verdadeira fonte normativa das políticas relacionadas ao tema.

A definição dos setores e agentes beneficiados pelas políticas de fomento remete à seleção dos objetivos de política econômica, seara em que existe uma grande discricionariedade conferida pela Constituição da República ao Legislativo, o qual, por sua vez, tende a atribuir não menor liberdade ao Executivo nesse assunto. A principal questão resultante da eleição de setores e agentes a serem beneficiados pelo incentivo estatal é bem expressa no discurso contrário às medidas de caráter horizontal ${ }^{98}$. Em suma, pode-se levantar o argumento de que as políticas de fomento criam distorções alocativas (canalizando recursos em sentido diverso do que a demanda e a oferta "naturalmente" o fariam), se não mesmo consagram situações injustas, na medida em que podem beneficiar setores que não mereçam benefícios oriundos do erário. De fato, essas razões não podem ser ignoradas. É fundamental que as políticas de fomento atentem para agentes e atividades que realmente demandem o incentivo e sejam efetivamente portadores de potencial de irradiação de efeitos benéficos à economia como um todo. Mas a crítica que se assenta no argumento de que o Estado tem de ser neutro em face dos diversos setores da economia, tem de conviver com o fato de que todo e qualquer investimento público pode ser questionado com base em tal alegação. Até mesmo medidas de caráter horizontal podem ser direcionadas a determinados beneficiados.

De todo modo, as políticas de incentivo devem atenção aos motivos que as determinam: se elas visam fazer frente a um fator conjuntural, devem restar vigentes apenas enquanto subsistentes às causas que as legitimam, sob pena de que outros setores ou atividades realmente demandantes de incentivos deixem de ser fomentados.

\footnotetext{
${ }^{97} \mathrm{~A}$ prescrição do incentivo à atividade cooperada também aparece no art. 146, III, c: "Cabe à lei complementar: III - estabelecer normas gerais em matéria de legislação tributária, especialmente sobre: c) adequado tratamento tributário ao ato cooperativo praticado pelas sociedades cooperativas."

${ }^{98}$ Tópico 1.3.2.1, acima.
} 


\subsubsection{Fomento e exigências de contrapartidas dos beneficiados}

Cabe também ressaltar a necessidade de avaliação da relação entre o montante de recurso público investido e a potencialidade de benefícios que a ação fomentadora pode gerar. Esse juízo aborda o fomento como uma espécie de investimento que, como qualquer investimento público, deve ser amparado em análise de risco de insucesso e de retorno potencial.

Não há regra que determine se o fomento deve corresponder integralmente aos recursos demandados ao desenvolvimento de uma determinada atividade, nem se cabe exigir do beneficiado o aporte de algum montante. De todo modo, exigir contrapartidas do beneficiado, principalmente as que dizem respeito a desempenho, pode servir como estímulo à sua eficiência ${ }^{99}$, evitando que o agente fomentado se acomode em razão da percepção do benefício estatal; além disso, a imposição de contrapartidas tendem a propiciar maior comprometimento da parte que recebe os recursos públicos, em razão de fazê-la incorrer em riscos econômicos.

Por isso é razoável presumir que o percentual de recursos advindos do incentivo estatal, em face da totalidade do capital exigido em cada situação, deve variar proporcionalmente ao interesse público presente, de modo que projetos que não estabeleçam o mínimo de engajamento e incursão no risco pelo particular só se justificam em situações bastante peculiares - tais como a reduzida capacidade econômica dos agentes beneficiados (como em programas de agricultura familiar, reforma agrária e de apoio a micro empresas); a grande incerteza em relação a resultados (pesquisa científica) ou a inviabilidade ou desnecessidade de retorno financeiro do empreendimento (como ocorre em atividades culturais - teatro, cinema, dança etc - e assistenciais). Nessas situações, exigir grandes contrapartidas ou assunção de risco pode desestimular o exercício das atividades fomentadas, ao passo que o objetivo de política pública em jogo pode ser, em verdade, o simples exercício da atividade, independente do retorno financeiro que ela dê. Nesses casos, então, é de se instituir, ao menos, mecanismos de fiscalização que assegurem o efetivo desempenho da atividade incentivada.

Por conseguinte, à medida que os agentes fomentados são dotados de maior capacidade econômica, bem como reste evidente que a ação incentivada tem aptidão de

99 Cf NASSIF, André. "Uma proposta de política industrial para o Brasil: objetivos, critérios e setores prioritários". Revista do BNDES, Rio de Janeiro, v. 10, n. ${ }^{\circ}$ 20, 2003 e "Uma contribuição ao debate sobre a nova política industrial brasileira". Rio de Janeiro: BNDES, 2003. 
produzir resultados econômicos concretos, o Estado pode e deve exigir garantias de retorno do investimento e de incursão no risco do negócio pelo beneficiado. Em todo caso, não há impedimentos a que o poder público estabeleça condições para o acesso ao incentivo, cujo descumprimento implique até mesmo na devolução do montante repassado ao beneficiário, sem prejuízo de outras sanções.

\subsubsection{Fomento, guerra fiscal e desenvolvimento nacional}

Ligada ao tema das contrapartidas está a questão da guerra fiscal, eis que se trata de analisar se as ações de fomento têm o condão de reverter em benefícios para a sociedade mais do que o custo efetivo ou de oportunidade que acarretam ao poder público. No caso, os custos dizem respeito à receita tributária renunciada e demais gastos realizados por Estados e Municípios que, a partir de início da década de 1990, a título de executarem suas políticas industriais, protagonizaram uma verdadeira disputa por empresas que pretendiam se instalar em seus territórios.

Em razão da crise econômica vivenciada na década de 1990, a perda da capacidade de ação do governo federal em matéria de política de desenvolvimento industrial, a retomada do fluxo de investimentos externos e a estrutura tributária atribuidora de autonomia a Estados e Município ${ }^{100}$, os governos subnacionais passaram a oferecer vantagens diversas às empresas. Isso provocou uma reação em cadeia, principalmente porque, se um determinado setor contava com incentivos num Estado, o outro Estado também se via forçado a concedê-los, sob risco de que as firmas instaladas em seu território migrassem.

O resultado dessa disputa foi uma perda líquida de arrecadação nacional se não, mesmo, a assunção progressiva de despesas públicas para fazer frente aos programas de fomento. Tudo isso foi feito a despeito do art. 155, §2 , XII, g, da Constituição da República e da Lei Complementar n. ${ }^{\circ}$ 24/75. O texto constitucional prescreve que cabe à Lei Complementar "regular a forma como, mediante deliberação dos Estados e do Distrito Federal, isenções, incentivos e benefícios fiscais serão concedidos e revogados", o que é feito pelo citado diploma, que estabeleceu o Conselho Nacional de Política Fazendária

${ }^{100}$ FERREIRA, Glenda, Políticas de Desenvolvimento Regional e Guerra Fiscal. Doutorado em Economia. Unicamp, 2005, p. 135. Para uma análise detalhada de alguns programas estaduais no campo da indústria automotiva, ver SILVA ALVES, Maria Abadia. Guerra Fiscal e Finanças Federativas no Brasil: O Caso do Setor Automotivo.. Mestrado em Economia, Unicamp, 2001. 
(CONFAZ). Pelas regras desse colegiado, as desonerações fiscais têm de ser objeto de aprovação unânime. Contudo, essa sistemática foi levada ao descrédito em razão da prevalência dos interesses locais, de forma que ela foi ignorada muitas vezes - o que resultou na instauração de um significativo contencioso no Supremo Tribunal Federal, provocado principalmente pelos Estados que sofreram emigração de empresas ${ }^{101}$. Mais recentemente, a Lei de Responsabilidade Fiscal, em seu artigo 14, tratado adiante, também tem a finalidade de conter a concessão de benefícios tributários, pois condiciona tal medida à redução de gastos ou ao incremento de receita.

A guerra fiscal dá evidências de que, se na ótica da entidade fomentadora, sempre há uma justificativa capaz de legitimar sua ação e a possibilidade de demonstrar que, no âmbito de sua competência jurídica, os incentivos se mostram um verdadeiro investimento cujos frutos serão colhidos no longo prazo, nem sempre se poderá dizer o mesmo ao se adotar uma visão global do assunto.

Estratégias de fomento que não sejam pensadas no âmbito de um projeto de alcance mais amplo, podem ter seu potencial reduzido, pois, se do ponto de vista regional, podem fazer sentido, na perspectiva nacional podem resultar em perdas líquidas de recursos públicos. Daí a importância de se estabelecer um plano nacional de desenvolvimento que leve em conta os planos regionais. Se as ações de fomento se dão num contexto de disputa, há chance de que o país deixe de auferir os benefícios que o incentivo estatal estaria apto a produzir $^{102}$.

${ }^{101}$ A maioria das lides discute a (in)observância das regras de concessão de benefícios de tributos estaduais. 102 “As políticas de desenvolvimento dos Estados têm sua lógica invertida, deixando de ter o caráter de planejamento estadual para se configurarem como projetos orientados para determinadas empresas privadas. $O$ resultado é o leilão de facilidades oferecidas pelos Estados, estimulados pelas empresas. Não pode haver homogeneidade interestadual onde um Estado decide, unilateralmente, sobre incentivos que os outros não podem conceder. Desta maneira, quando um Estado ganha (isto se houver ganho de fato, o que na maioria das vezes não ocorre), os outros perdem. O processo de concessão de incentivos fiscais estaduais caracteriza-se pelo desperdício de dinheiro público, pois os possíveis ganhos em bem-estar não se comparam aos custos econômicos da atração dos investimentos e aos custos sociais da diminuição da atividade econômica nos Estados "perdedores". São muito poucos os empreendimentos que, nacionalmente, necessitam ou justificam uma política estadual de concessão de benefícios fiscais. A desconcentração industrial é um objetivo nacional, que deve ser coordenado com a União e todos os demais entes federados. Ao renunciar à arrecadação, geralmente em favor de indústrias transnacionais, o que denota o desperdício de dinheiro público, o Estado "vencedor" acaba prejudicando os serviços públicos que deve prestar para sua própria população.A guerra fiscal foi acirrada com crise financeira dos Estados. Porém, conforme os incentivos vão se avolumando, perdem a capacidade de estimular o investimento, tornando-se mera renúncia de arrecadação. Além disto, os Estados mais pobres acabam perdendo a capacidade de investir em sua própria infra-estrutura e serviços públicos. E, como todos oferecem incentivos fiscais, o que pesa na decisão final é a infra-estrutura já existente, o que só favorece os Estados mais desenvolvidos. Portanto, o argumento da desconcentração industrial e do desenvolvimento equilibrado como justificativa da guerra fiscal é falso" In BERCOVICI, Gilberto. Desigualdades Regionais, Estado e Constituição. São Paulo: Max Limonad, 2003, pp. 186-187. 


\subsubsection{Fomento direto e indireto}

A questão da intensidade da presença estatal na atuação mediante incentivo conduz a um outro importante tópico do tema: as possibilidades de multiplicação das condutas fomentadas. O Estado pode favorecer não apenas a realização de determinada conduta, mas estruturar uma sistemática de incentivos mais ampla, na qual o particular beneficiado pelo fomento acabe sendo induzido a outras práticas relacionadas à sua atividade. Aqui bem se expressa o caráter ordenador do fomento porque, no limite, podem-se arquitetar diversas políticas públicas com base em algumas poucas coordenadas da entidade fomentadora.

Os mecanismos de condicionamento da concessão de incentivos consubstanciam uma técnica muito importante na criação de externalidades positivas oriundas da atividade fomentada e possuem, pois, grande relevância na construção de um padrão de desenvolvimento que leve em consideração fatores que não estejam estritamente ligados ao desempenho da atividade produtiva ${ }^{103}$. Não é de se desprezar, por certo, que o incremento das condições a serem cumpridas pelo beneficiário corresponde a um aumento de custos nos quais ele irá incorrer. Mas apesar de não existir um critério a priori capaz de definir a carga de requisitos e condicionantes que o poder público pode exigir, é de se avaliar se os encargos e condicionantes podem desincentivar a adesão aos benefícios do fomento e, por conseguinte, obstaculizar o exercício da atividade que se pretende incentivar. De todo modo, é possível aplicar uma estrutura de incentivos que ofereça vantagens em proporção à assunção de encargos a que o particular se disponha a assumir.

Eis um exemplo simples: um banco de fomento destina linha de crédito a uma empresa (fomento direto), sendo que as condições do empréstimo podem se mostrar crescentemente vantajosas (ex: diminuição das taxas de juros) na medida em que o tomador adote determinadas condutas, tais como associar-se a uma instituição de pesquisa relacionada à sua área de produção, empregue sistemas de certificação para comercializar seus produtos, utilize um percentual de insumos de conteúdo nacional em seu processo produtivo. No somatório das condições impostas à fruição do crédito subsidiado, há varias outras atividades, integradas na cadeia produtiva ou não, que acabam sendo prestigiadas ou viabilizadas. Obviamente que, em se tratando de fomentar uma cadeia produtiva, é possível o fomento a uma única etapa da cadeia produtiva (mais viável que seja a empresa líder), esperando que as demais atividades a montante também se beneficiem. Todavia, tem sido

\footnotetext{
${ }^{103}$ Apenas para ilustrar esse tema, cite-se o crescimento de exigências relativas à sustentabilidade ambiental que os bancos de fomento têm feito como condição de financiamento.
} 
cada vez mais frequente, nos programas de financiamento (não só os exercidos pelos bancos de fomento), ações que abarcam toda a cadeia produtiva ${ }^{104}$.

\subsection{OS INSTRUMENTOS JURÍDICOS DO INCENTIVO (FOMENTO)}

Como já assinalado, a função estatal de incentivo se consubstancia em inúmeras formas, cada qual com uma funcionalidade mais pronunciada, mais ou menos afeita a obter determinado objetivo ou apta a ser aplicada em cada setor. As políticas de promoção dos APLs congregam diversos desses mecanismos, cuja face jurídica este tópico visa expor, ainda que sumariamente.

\subsubsection{Subvenções e doações de bens públicos}

Nesta categoria tem-se a simples transferência de patrimônio estatal para o patrimônio privado, seja na forma de recursos financeiros, seja na forma de bens tangíveis ou intangíveis. Essas formas de fomento têm a vantagem de ser, em princípio, mais transparentes, pois são nítidas a natureza e a magnitude da vantagem atribuída, ao passo que, nas demais formas, nem sempre se identifica de plano o volume de recursos que beneficiará o particular ${ }^{105}$. A desvantagem desses instrumentos, todavia, em caso de descumprimento das condições do incentivo, é a dificuldade de reversão do benefício aos cofres públicos depois que ele passa a integrar o patrimônio dos beneficiados, o que costuma exigir intervenção judicial. Para as ações de execução continuada, que demandem a continuidade da percepção da subvenção pelo particular (subvenção periódica ${ }^{106}$ ), o poder público consegue se acautelar com a simples possibilidade de interrupção do benefício; mas se o projeto em questão envolve a doação de bem imóvel (ou a concessão

\footnotetext{
${ }^{104}$ No âmbito do BNDES, é de se fazer menção ao Pró-Aeronáutica, que financia micro, pequenas e médias empresas, sediadas no País, integrantes da cadeia produtiva da indústria aeronáutica brasileira.

105 Um financiamento subsidiado (item 2.3.2, adiante), por exemplo, tem seu benefício bem expresso somente no momento de sua contratação, quando se pode verificar a diferença entre os juros então praticados pela instituição de fomento vis a vis os de mercado; como estes podem variar bastante ao longo do tempo, apenas ao final do prazo do mútuo se pode dimensionar o montante efetivo do incentivo.

${ }^{106}$ A expressão é de SOUTO, Marcos Juruena V. "Estímulos positivos", em MARTINS CARDOZO, José Eduardo; LOPES QUEIROZ, João Eduardo; BATISTA DOS SANTOS Márcia W. (Org.). Curso de Direito Administrativo Econômico. $1^{\text {a }}$ ed. São Paulo: Malheiros, 2006, v. II, p. 138.
} 
de qualquer direito real) no início de sua execução, a providência da reversão é mais trabalhosa.

\subsubsection{Subvenção}

Por subvenção pode-se entender a outorga de ajuda pecuniária com a finalidade de favorecer o exercício de uma determinada atividade, operando a transferência direta de recursos financeiros não reembolsáveis aos agentes beneficiados. É mecanismo semelhante à doação do direito civil, mas que, no regime das finanças públicas, assume contornos próprios. A subvenção pode se realizar ao início de uma determinada atividade, como viabilização de sua instalação e/ou acompanhar seu desenvolvimento, ou ainda dar-se apenas ao fim (como uma espécie de prêmio ${ }^{107}$ ). Ela pode ter como referência o produto final (aplicando-se sobre o seu preço) ou incidir sobre um insumo importante (como ocorre com a subvenção a financiamentos).

O emprego da subvenção tem lugar especialmente em atividades:

(i) cujo exercício não enseje lucro e implique na prestação de um serviço público em sentido amplo (assistência social, saúde, educação). Este é o campo de atuação das entidades do terceiro setor, que contam com o fomento do Estado para desempenhar atividades cuja titularidade lhe pertence. Não se trata propriamente do campo de aplicação das políticas de desenvolvimento produtivo, mas é de grande relevância para a economia do setor público, pois os agentes privados - aqui, agindo sem intuito lucrativo ${ }^{108}$ - atuam muitas vezes em caráter de substituição ao Estado, cuja rede de assistência não basta para atender à demanda da população nessas áreas;

(ii) que, mesmo podendo, em tese, gerar lucro, o apelo ao mercado consumidor não é suficiente para garantir remuneração adequada. Aqui, os exemplos mais notados são os das atividades culturais e desportivas. O fomento estatal age em prol das manifestações artísticas e esportivas que não se mantêm somente à custa do que poderiam obter do mercado, até porque, em alguns casos, como a arte de vanguarda e o esporte amador, o mercado é praticamente inexistente. Apesar da grande relevância dessas atividades para a formação do capital simbólico da sociedade, essas manifestações têm

${ }^{107}$ SOUTO, Marcos Juruena V. "Estímulos positivos", op. cit. p. 138.

${ }^{108}$ Não estão sendo consideradas a exploração dos serviços de saúde e educação por particulares no regime de atividade econômica em sentido estrito, com intuito lucrativo. 
pequena relevância comercial e não se prestam a integrar estruturas de produção em escala, de modo que os mecanismos de incentivo que lhe são aplicáveis não costumam integrar políticas de desenvolvimento produtivo. De todo modo, vale citar que os mais relevantes mecanismos de incentivo à cultura e ao desporto do ponto de vista do volume de recursos, apesar de basearem-se em desonerações tributárias, na perspectiva do beneficiário operam como uma subvenção: o montante que o Estado renuncia sob a forma de tributo é transferido ao agente agraciado na forma de recursos financeiros como se fosse uma doação $^{109}$.

(iii) cujo exercício em si, independente da produção de resultados, seja de interesse público (ex: estudo e pesquisa). Essa modalidade de subvenção está no limiar entre a política educacional (ela própria, no limite, integrante de uma estratégia nacional de desenvolvimento produtivo na medida em que é fundamental para a formação de mão-deobra) e a política industrial. A concessão de bolsas de estudo e pesquisa tem evidente e forte vinculação - senão mesmo sobreposição ou identidade - com o fomento à pesquisa aplicada e tecnologia; a diferença é que nem sempre bolsas de estudos e pesquisa tem de estar vinculadas ao desenvolvimento de um produto, mas podem se prestar à pesquisa teórica, sem finalidade de emprego industrial imediato. Na esfera federal, destaca-se a ação do O Conselho Nacional de Desenvolvimento Científico e Tecnológico (CNPq) na concessão de bolsas de estudo, conquanto praticamente todos os Estados da federação contem com entidades de fomento ao ensino igualmente voltadas a tal escopo, sendo que elas também subvencionam pesquisa aplicada.

(iv) de elevados riscos de obtenção de resultados (ex: ciência e tecnologia). A presença de grande incerteza em relação a um resultado produtivamente útil tende a afugentar o interesse dos investidores privados e, por isso, implica sérias dificuldades na obtenção de recursos por parte dos exercentes da atividade. A incerteza em relação a determinados projetos (eventualmente portadores de significativos proveitos para toda a sociedade) pode ser tamanha que até mesmo o oferta de financiamento público subsidiado pode se revelar aversiva ao empreendedor e/ou pesquisador, eis que ele poderá não ter como arcar com o pagamento futuro dos empréstimos obtidos. Por isso é que se justificam os recursos não reembolsáveis, de aplicação bastante presente em programas de fomento à

\footnotetext{
${ }^{109}$ As Leis n. ${ }^{\text {o } 8.313 / 91 ~(L e i ~ R o u a n e t / ~ L e i ~ d e ~ I n c e n t i v o ~ a ̀ ~ C u l t u r a), ~ 8.685 / 93 ~(L e i ~ d o ~ A u d i o v i s u a l) ~ e ~ 11.438 / 06 ~}$ (Lei de Incentivo ao Esporte), estas duas últimas modificadas pela Lei n. ${ }^{\circ}$ 11.472/07, permitem o financiamento de eventos culturais, obras cinematográficas, e eventos esportivos, respectivamente, mediante a arrecadação de valores que podem ser deduzidos do imposto de renda devido pelos doadores.
} 
inovação tecnológica. Somente no âmbito do Ministério da Ciência e Tecnologia (MCT), há diversos fundos setoriais que são usados no financiamento das atividades de pesquisa e desenvolvimento $^{110}$. Na esfera federal, a subvenção para ciência e tecnologia é concedida sobretudo pela Financiadora de Estudos e Projetos (FINEP), empresa pública federal vinculada ao MCT, a qual, baseada na Lei de Inovação (Lei n. ${ }^{\circ} 10.973 / 04$ ) e na Lei n. ${ }^{\circ}$ 11.196/05 (Lei do Bem), desenvolve ações como o Programa de Apoio à Pesquisa a Micro e Pequenas Empresas - Pappe-Subvenção ${ }^{111}$, Programa Subvenção Econômica ${ }^{112}$ e Primeira Empresa Inovadora - Prime ${ }^{113}$. Vale notar aqui que a FINEP, a exemplo do que pode fazer qualquer outra entidade de fomento, atenta para a questão regional e da capacidade econômica das empresas beneficiadas; isso se traduz no direcionamento de recursos disponíveis ou na formulação de um menor volume de contrapartidas das empresas de menor porte e/ou situadas nas regiões Norte, Nordeste e Centro-Oeste ${ }^{114}$. Também o $\mathrm{BNDES}^{115}$, o $\mathrm{CNPq}^{116}$ e o $\mathrm{BNB}^{117}$ possuem programas de subvenção à ciência e tecnologia.

${ }^{110}$ Fundo Nacional de Desenvolvimento Científico e Tecnológico (FNDCT), Petróleo e Gás (CTPetro), Infra-Estrutura, Transporte, Energia, Telecomunicações (Funtel), Recursos Hídricos, Recursos Minerais, Saúde, Biotecnologia, Agronegócio, Tecnologia de Informação, Aeronáutico, Espacial e Verde Amarelo. O Fundo Verde-Amarelo busca a interação universidade/empresas, via financiamento à inovação de empresas, e via equalização de juros dos financiamentos da Finep às atividades de $\mathrm{P} \& \mathrm{D}$.

${ }^{111}$ Programa que concede apoio financeiro na forma de recursos não reembolsáveis a empresas de base tecnológica de pequeno porte por intermédio de entidades estaduais de de amparo à pesquisa, Sebraes ou federações das indústrias; destinado ao custeio direto de atividades de pesquisa,desenvolvimento e inovação em empreendimentos selecionados.

${ }^{112}$ Subvenciona despesas de custeio das atividades inovativas das empresas.

${ }^{113}$ Programa que custeia recursos humanos qualificados e serviços de consultoria especializada em estudos de mercado, serviços jurídico, financeiro, certificação e custos, entre outros, durante 12 meses, destinados a empresas nascentes que desenvolvam produtos de elevado conteúdo inovativo em seus produtos e serviços.

${ }^{114}$ No edital dos programas de subvenção do ano de 2007 a questão regional foi incorporada mediante a diminuição da contrapartida exigida a empresas que se situavam na área de competência da SUDAM e SUDENE. Já os editais do ano de 2009 destinavam $40 \%$ dos recursos a micro e pequenas empresas, e $30 \%$ a empresas localizadas na região Nordeste, Norte e Centro-Oeste.

115 O Fundo Tecnológico (Funtec) subvenciona até 90\% dos gastos em projetos de pesquisa, desenvolvimento e inovação em áreas estratégicas, definidas pelo BNDES anualmente, executados por Instituições tecnológicas (ITs) e instituições de apoio (IAs) sem fins lucrativos com interveniência de empresas participantes, dispensada a interveniência destas quando o objeto social das ITs e IAs contemplar as atividades de produção e comercialização dos produtos ou processos resultantes.

${ }^{116}$ Programa de Capacitação de Recursos Humanos para Atividades Estratégicas (RHAE), concessão de bolsas para contratação de pessoal qualificado por empresas que desenvolvam projetos de aprimoramento tecnológico.

${ }^{117}$ Fundo de Desenvolvimento Científico e Tecnológico (FUNDECI), o qual corresponde ao aporte de recursos não reembolsáveis para a realização de pesquisas tecnológicas e a difusão de seus resultados $\mathrm{O}$ aporte de recursos é restrito a instituições sem fins lucrativos, não podendo prover recursos diretamente a empresas com fins industriais/comerciais, embora estas possam surgir de incubadoras de empresas ou desenvolver novas tecnologias. 
(v) submetidas a riscos mercadológicos que desincentivem seu exercício. Note-se que o risco, aqui, não é da inexistência de resultados (que pode acometer uma pesquisa científica), mas de resultados efetivamente proveitosos ao produtor, que, diante da incerteza de obtenção de ganhos e do risco de incorrer em prejuízo, pode deixar de exercer sua atividade ou fazê-lo aquém de sua capacidade de produção total.

O exemplo mais importante de emprego de política de fomento baseada nessa modalidade é a política agrícola. A cultura de alimentos submete-se, por diversos fatores, a fortes oscilações de preços, não raramente, em desfavor dos interesses dos produtores. Assim é que, diante de um quadro de extrema incerteza em relação à remuneração que pode auferir, correndo, pois, risco de prejuízo, o agricultor pode simplesmente optar por não produzir, ou produzir menos do que poderia. Caso todos os agricultores decidam de igual maneira pela não produção, os danos para o abastecimento da coletividade são incomensuráveis. No mais, a estabilização dos preços agrícolas ajuda na contenção dos índices gerais de inflação.

Na esfera federal, a Política de Garantia de Preços Mínimos (PGPM), cujas bases

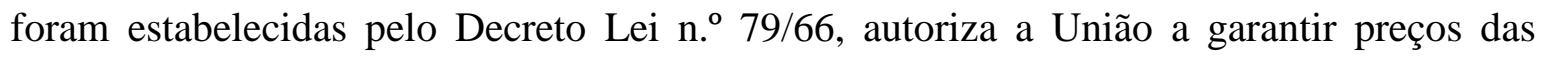
atividades agrícola, pecuária ou extrativa. Até meados dos anos 1990, isso era feito predominantemente por meio de aquisições governamentais e formação de estoques públicos, estabelecendo-se preços mínimos de garantia ao produtor e preços máximos de liberações de estoque. Atualmente, contudo, os principais instrumentos da PGPM são o Programa de Escoamento da Produção e os Contratos de Opção de Venda de Produtos Agrícolas, os quais, em linhas gerais, visam desonerar o governo da compra e estocagem de produtos, fomentando, em verdade, a comercialização dos bens ${ }^{118}$. De acordo com a Lei n. ${ }^{\circ}$ 8.427/92 e suas diversas alterações, as subvenções econômicas podem se dar pela equalização de preços de produtos agropecuários ou vegetais de origem extrativa ${ }^{119}$, ou

\footnotetext{
${ }^{118}$ Para um histórico da PGPM, ver DELGADO, Guilherme C. Estoques Governamentais de Alimentos e Preços Públicos. Brasília: Ipea, Texto para Discussão, 395, 1995 e CONCEIÇÃO, Júnia Cristina P. R. da. Contribuição dos novos instrumentos de comercialização (contratos de opção e pep) para estabilização de preço e renda agrícolas. da Conceição, Brasília, Ipea, Texto para Discussão, 927, 2002.

119 “Art. $2^{2}$ A equalização de preços consistirá em subvenção, independentemente de vinculação a contratos de crédito rural, nas operações amparadas pela política de garantia de preços mínimos, de que trata o Decreto-Lei $n^{o}$ 79, de 19 de dezembro de 1966, equivalente: I - nas operações efetuadas com produtos agropecuários integrantes dos estoques públicos: a) à parcela do custo de aquisição do produto que exceder o valor obtido na sua venda, observada a legislação aplicável à formação e alienação de estoques públicos; b) à cobertura das despesas vinculadas aos produtos em estoque; II - à concessão de prêmio ou bonificação, apurado em leilão ou em outra modalidade de licitação, para promover o escoamento do produto pelo setor privado; III - no máximo, à diferença entre o preço de exercício em contratos de opções de venda de produtos agropecuários lançados pelo Poder Executivo ou pelo setor privado e o valor de mercado desses
} 
pela equalização de taxas de juros e outros encargos financeiros de operações de crédito rural, incluídos nestas os bônus de adimplência e os rebates nos saldos devedores de financiamentos rurais concedidos, direta ou indiretamente, por bancos oficiais federais e bancos cooperativos ${ }^{120}$. Os valores das subvenções e dos preços mínimos são definidos pela Administração, variando o órgão detentor da decisão a depender do incentivo em questão $^{121}$.

(vi) Além das hipóteses acima mencionadas, a subvenção pode ter o propósito de reduzir o preço final de um produto ou serviço ao consumidor, propiciando o seu acesso a um universo maior de pessoas. O subsídio pode ser direcionado diretamente ao produtor, sob o compromisso da prática de um preço limite, ou pode ser direcionado ao comprador, outorgando-lhe um crédito de uso específico que incentivo o consumo (que pode assumir a forma de um "vale" - "vale-alimentação", "vale-gás", “vale-leite”). Segue essa lógica o Proex-Equalização, programa destinado a assegurar que as taxas de juros de finaciamento à exportação de bens e serviços nacionais sejam aproximadas das praticadas no mercado externo. Nesse caso, recursos do Tesouro Nacional, consubstanciados em títulos públicos, são usados no pagamento da diferença entre a taxa cobrada pela instituição financeira do comprador/importador do produto nacional e a taxa que seria em princípio aplicável

produtos, apurado em leilão ou em outra modalidade de licitação; IV - no máximo, à diferença entre o preço mínimo e o valor de venda de produtos extrativos produzidos por agricultores familiares enquadrados nos termos do art. $3^{\circ}$ da Lei $n^{o} 11.326$, de 24 de julho de 2006, ou por suas cooperativas e associações, limitada às dotações orçamentárias e aos critérios definidos em regulamento; ou $V$ - ao percentual do prêmio pago na aquisição de opção de venda, isolada ou combinada ao lançamento de opção de compra, pelo setor privado. $\S 1^{\circ}$ A concessão da subvenção a que se referem os incisos II a $V$ do caput deste artigo exonera o Governo Federal da obrigação de adquirir o produto, que deverá ser comercializado pelo setor privado".

120 “Art. $4^{\circ}$ A subvenção de equalização de taxas de juros ficará limitada ao diferencial de taxas entre o custo de captação de recursos, acrescido dos custos administrativos e tributários a que estão sujeitas as instituições financeiras oficiais e os bancos cooperativos, nas suas operações ativas, e os encargos cobrados do tomador final do crédito rural."

${ }^{121}$ Segundo o art. $3^{\circ}$, incs. I e II da Lei n. ${ }^{\circ}$ 8.427/92, a concessão de subvenção econômica, sob a forma de equalização de preços, obedecerá aos limites, às condições, aos critérios e à forma estabelecidos, em conjunto, pelos Ministérios da Fazenda, do Planejamento, Orçamento e Gestão, e da Agricultura, Pecuária e Abastecimento, de acordo com as disponibilidades orçamentárias e financeiras existentes para a finalidade, com a participação do Ministério do Desenvolvimento Agrário, quando se tratar das operações destinadas a atender a agricultura familiar ou do Ministério do Meio Ambiente, quando se tratar das operações destinadas a atender a produção extrativista oriunda da agricultura familiar. O CMN, por sua vez, é encarregado de definir os limites e a metodologia para o cálculo do preço de exercício para o lançamento de Contratos de Opção Pública e Privada de Venda dos produtos amparados pela Política de Garantia de Preços Mínimos PGPM, mas o preço de exercício para cada produto deve ser definido em conjunto pelos Ministérios da Agricultura, Pecuária e Abastecimento e da Fazenda (art. 3º-A da Lei 8.472/92). Já o Decreto-lei 79 estabelece que "[os] Os preços mínimos básicos serão definidos pelo Conselho Monetário Nacional - CMN, levando em conta os diversos fatores que influem nas cotações dos mercados, interno e externo, e os custos de produção, com base em proposta encaminhada ao Ministério da Fazenda pelo Ministério da Agricultura, Pecuária e Abastecimento" (art. 5, caput), além de autorizar que a garantia de preço pode se extender por mais de um ano ou safra "quando isso interessar à estabilidade da agricultura e à normalidade de abastecimento" (art. $\left.5^{\circ}, \S 2^{\circ}\right)$. 
(superior porque incorpora o custo Brasil); de fato, o que ocorre é o subsídio à instituição financeira para que ela reduza as taxas de juros cobradas.

Cabem alguns comentários gerais a respeito do instituto da subvenção. Geraldo Ataliba destacava a importância da imposição do que ele chama de compensações pela outorga dos recursos não reembolsáveis, isto é, a instituição de contrapartidas pelo poder público em face do beneficiário $^{122}$. Talvez, na subvenção, a necessidade da imposição de condicionantes e contrapartidas seja mais importante do que nas demais formas de fomento porque o particular pode auferir diretamente do Estado um proveito econômico líquido pelo exercício de sua atividade, consubstanciado na remuneração pelo quanto executado ao passo que nas demais espécies de ações de fomento, o proveito econômico apenas propicia que ao beneficiado a possibilidade de remunerar-se. A subvenção, pois, deve vir acompanhada de exigências de desempenho, sob o risco de premiar a ineficiência ao garantir uma remuneração fixa ao beneficiário, independente dos resultados que produza.

A Lei n. ${ }^{\circ} 4.320 / 64$ trata dos aspectos fiscais da subvenção, e o faz sob a rubrica das transferências correntes (isto é "dotações para despesas às quais não corresponda contraprestação direta em bens ou serviços" ${ }^{123}$ ), as quais, por sua vez, incluem-se na seção sobre despesas correntes. Subvenção, para fins fiscais, portanto, não tem estatuto de investimento (o que ocorreria caso o conceito se subsumisse à categoria de despesa de capital), tampouco é destinada à realização de investimento pelos beneficiados. Isso porque, nos termos do art. $12, \S 3^{\circ}$, subvenções são "transferências destinadas a cobrir despesas de custeio das entidades beneficiadas"; custeio, por sua vez, refere-se às despesas de "manutenção de serviços anteriormente criados, inclusive os destinados a atender a obras de conservação e adaptação de bens imóveis" (art. 12, § $1^{\circ}$ ). Disso se pode concluir que a subvenção, em princípio, é mais afeita a ações de permanência, e não de expansão, da atividade econômica. A Lei estabelece uma distinção entre subvenções sociais (" as que se destinem a instituições públicas ou privadas de caráter assistencial ou cultural, sem finalidade lucrativa""124) e subvenções econômicas, ("as que se destinem a empresas

\footnotetext{
122 “as exigências do regime publicístico impõem, portanto, alteração no caráter não contraprestacional das subvenções. Por isso, se estas persistem marcadas por esta indelével peculiaridade, a gratuidade que as matiza, embora mantida na estrutura do instituto, não exclui uma compensação inserida em posição nucelar e decisiva, entre seus pressupostos" in Subvenção municipal a empresas, como incentivo à industrialização Justitia, v.72, p. 153 apud BANDEIRA DE MELLO, Celso Antônio \& ATALIBA, Geraldo. "Subvenções: Natureza jurídica". Revista de Direito Público, vol. 20, abr./jun. 1972, p. 88.

123 Art. $12, \S 2^{\circ}$.

${ }^{124}$ Art. $12, \S 3^{\circ}$, I. As subvenções sociais, em princípio, têm a função de suplementar os recursos financeiros necessários à prestação de serviços de assistência social, médica e educacional, incitando os particulares a
} 
públicas ou privadas de caráter industrial, comercial, agrícola ou pastoril ${ }^{, 125}$ ), sendo estas as de maior interesse para o presente trabalho.

As subvenções econômicas (ou, como se tem recentemente classificado, as equalização de preços e taxas ${ }^{126}$ ), quando destinadas ao setor privado ${ }^{127}$, visam garantir uma remuneração mínima mediante a complementação da renda que o produtor auferiria caso dependesse somente do mercado ${ }^{128}$. Em suma, essa categoria abrange as hipóteses " $i i$ " a "vi" supra. Tal incentivo deve constar da lei específica bem como da lei orçamentária ${ }^{129}$. Em sentido semelhante, o art. 26 da Lei de Responsabilidade Fiscal, impõe restrições ao emprego desse instrumento (bem como de outros mecanismos de dispêndio público de efeitos fiscais correlatos: concessão de empréstimos, financiamentos, e participação em constituição ou aumento de capital) ${ }^{130}$.

desempenharem tais funções. Logo, as entidades que as recebem não podem ter o patrocínio governamental como única fonte de receita, devendo envidar esforços para obterem seus meios de financiamento. A Lei 4.320/64 estabelece ainda que o valor das subvenções deve guardar pertinência com os serviços efetivamente disponibilizados aos usuários e seja estabelecido conforme parâmetros de eficiência estipulados pela entidade subvencionadora. Isso visa garantir a aplicação eficiente do dinheiro publico na medida em que incentivam os beneficiários interessados em incrementar recursos recebidos do poder público a ampliar o atendimento e a diminuir custos. Para a concessão da subvenção, o poder público deve avaliar as condições de funcionamento da entidade beneficiada, de forma que o auxílio estatal pode se vincular a observância de determinados requisitos específicos - o que pode ter como efeito a realização de condutas outras que se coadunem com políticas públicas atreladas à atividade subvencionada (v.g, a realização de pesquisas científicas - no caso dos hospitais - ou o oferecimento de determinados cursos gratuitos em instituições de ensino). Desde a edição da Lei n. ${ }^{\circ}$ 9.709/99 (Organizações da Sociedade Civil de Interesse Público - Oscip) e da Lei n. ${ }^{\circ}$ 9.637/98 (Organizações Sociais - OS), tem-se percebido um reavivamento do estudo do uso das subvenções como medida de fomento às entidades do terceiro setor; para uma exposição sobre a função de fomento e o terceiro setor, cf. ROCHA, Silvio. Terceiro Setor. São Paulo: Malheiros, 2003.

${ }^{125}$ Art. $12, \S 3^{\circ}$, II

${ }^{126}$ A alteração da denominação da categoria foi veiculada pela Portaria Interministerial 163/01, editada pela Secretaria do Tesouro Nacional e Secretaria do Orçamento Federal. Entende-se que o art. 113 da Lei 4.320/64 autoriza o Poder Executivo a realizar tal espécie de mudança nas categorias fiscais. De acordo com o regulamento citado, equalização de preços e taxas são "despesas para cobrir a diferença entre os preços de mercado e o custo de remissão de gêneros alimentícios ou outros bens, bem como a cobertura do diferencial entre níveis de encargos praticados em determinados financiamentos governamentais e os limites máximos admissíveis para efeito de equalização". Percebe-se que a natureza do incentivo não se altera.

${ }^{127} \mathrm{O}$ art. 18, caput, admite a subvenção também a empresas estatais a fim de cobrir "déficits de manutenção": "A cobertura dos déficits de manutenção das emprêsas públicas, de natureza autárquica ou não, far-se-á mediante subvenções econômicas expressamente incluídas nas despesas correntes do orçamento da União, do Estado, do Município ou do Distrito Federal".

128 “Art. 18. (...) Parágrafo único. Consideram-se, igualmente, como subvenções econômicas: a) as dotações destinadas a cobrir a diferença entre os preços de mercado e os preços de revenda, pelo Govêrno, de gêneros alimentícios ou outros materiais; b) as dotações destinadas ao pagamento de bonificações a produtores de determinados gêneros ou materiais."

${ }^{129}$ Art. 19 da Lei n. ${ }^{\circ} 4.320$ e 26 da LRF.

130 "Art. 26. A destinação de recursos para, direta ou indiretamente, cobrir necessidades de pessoas físicas ou déficits de pessoas jurídicas deverá ser autorizada por lei específica, atender às condições estabelecidas na lei de diretrizes orçamentárias e estar prevista no orçamento ou em seus créditos adicionais. $\S 1^{\circ} O$ disposto no caput aplica-se a toda a administração indireta, inclusive fundaçães públicas e empresas estatais, exceto, no exercício de suas atribuições precípuas, as instituições financeiras e o Banco Central do 
As normas de comércio internacional apresentam algumas restrições ao emprego da subvenção. Atualmente, no âmbito do sistema da Organização Mundial de Comércio (OMC), vigem o "Acordo sobre Subsídio e Medidas Compensatórias" e o "Acordo sobre Subsídios e Medidas de Investimentos Relacionadas ao Comércio”, e ambos instituem impedimentos ao amplo uso das subvenções. No Acordo sobre Subsídio e Medidas Compensatórias, subsídio pode ser entendido, em apartada síntese, como uma contribuição financeira concedida por uma entidade governamental a um grupo específico de beneficiados $^{131}$.

O Acordo classifica os subsídios em proibidos (de uso completamente interditado, isto é "aqueles cuja concessão seja vinculada, de fato ou de direito, ao desempenho exportador do beneficiário ou ao uso pelo beneficiário de produtos nacionais em detrimento dos estrangeiros no seu processo produtivo ${ }^{132,), ~ r e c o r r i ́ v e i s ~(p r o i b i d o s ~ a p e n a s ~}$ se geraram efeitos danosos, isto é " a caracterização da ilegalidade do seu uso depende da

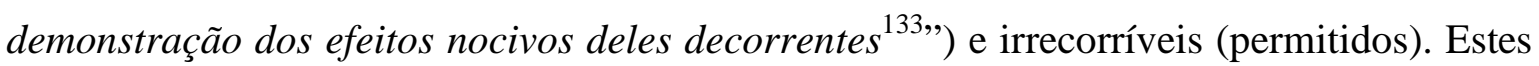
últimos são de aplicação bastante restrita, caracterizando-se por não apresentarem o traço

Brasil. § $2^{\underline{o}}$ Compreende-se incluída a concessão de empréstimos, financiamentos e refinanciamentos, inclusive as respectivas prorrogações e a composição de dívidas, a concessão de subvenções e a participação em constituição ou aumento de capital."

${ }^{131}$ Esta definição busca elucidar os aspectos essenciais da definição constante do Acordo, que é a seguinte: “ARTIGO 1 Definição de subsídio 1. Para os fins deste Acordo, considerar-se-á a ocorrência de subsídio quando: (a) (1) haja contribuição financeira por um governo ou órgão público no interior do território de um Membro (denominado a partir daqui "governo"), i.e.: (i) quando a prática do governo implique transferência direta de fundos (por exemplo, doações, empréstimos e aportes de capital), potenciais transferências diretas de fundos ou obrigações (por exemplo garantias de empréstimos); (ii) quando receitas públicas devidas são perdoadas ou deixam de ser recolhidas (por exemplo, incentivos fiscais tais como bonificações fiscais); (iii) quando o governo forneça bens ou serviços além daqueles destinados a infraestrutura geral ou quando adquire bens; (iv) quando o Governo faça pagamentos a um sistema de fundos ou confie ou instrua órgão privado a realizar uma ou mais das funções descritas nos incisos (i) a (iii) acima, as quais seriam normalmente incumbência do Governo e cuja prática não difira de nenhum modo significativo da prática habitualmente seguida pelos governos; ou (a) (2) haja qualquer forma de receita ou sustentação de preços no sentido do Artigo XVI do GATT 1994; e (b) com isso se confira uma vantagem".

132 Definição de Rabih Ali NASSER a partir do art. 3 do Acordo em A OMC e os Países em Desenvolvimento. São Paulo: Aduaneiras, p. 175. Veja-se o texto do Acordo "ARTIGO 3 PROIBIÇÃO 1. Com exceção do disposto no Acordo sobre Agricultura, serão proibidos os seguintes subsídios, conforme definidos no Artigo 1: (a) subsídios vinculados de fato ou de direito ao desempenho exportador, quer individualmente, quer como parte de um conjunto de condições, inclusive aqueles indicados a título de exemplo no Anexo I 5; (b) subsídios vinculados de fato ou de direito ao uso preferencial de produtos nacionais em detrimento de produtos estrangeiros, quer individualmente, quer como parte de um conjunto de condições; 2. O Membro deste Acordo não concederá ou manterá os subsídios mencionados no parágrafo 1 ".

${ }^{133}$ NASSER, Rabih Ali. A OMC e os Países em Desenvolvimento. São Paulo: Aduaneiras, p. 176. Os efeitos nocivos estão previstos no art. 5 do Acordo e são os seguintes: (a) dano à indústria nacional de outro Membro; (b) anulação ou prejuízo de vantagens resultantes para outros Membros, direta ou indiretamente, do GATT 1994, em especial as vantagens de concessões consolidadas sob o Artigo II do GATT 1994; (c) grave dano aos interesses de outro Membro. 
da especificidade ou, em caso de apresentarem, se subsumirem-se a uma das seguintes hipóteses tornam-se lícitos:

“(a) assistência para atividades de pesquisa realizadas por empresas ou estabelecimentos de pesquisa ou estabelecimentos de pesquisa ou de educação superior vinculados por relação contratual (....)"

“(b) assistência a uma região economicamente desfavorecida dentro do território de um membro, concedida no quadro geral do desenvolvimento regional (...)"

“(c) assistência para promover a adaptação de instalações existentes ${ }^{33}$ a novas exigências ambientalistas impostas por lei e/ou regulamentos de que resultem maiores obrigações ou carga financeira sobre as empresas (....)".

Ao contrário do que possa parecer, as hipóteses acima enunciadas não autorizam o uso intenso de subsídios em políticas de desenvolvimento produtivo, conquanto a situação específica das políticas de desenvolvimento regional sejam um autorizativo que torna o emprego desse instrumento praticamente imune a objeções ${ }^{134}$. Isto porque, se no caso da assistência para atividades de pesquisa e para adaptação a exigências ambientalistas há limites para o desembolso estatal, não há impedimentos à aplicação de subsídios em projetos de desenvolvimento regional se a região for área geograficamente delimitada e se as dificuldades não advierem de causas circustanciais e temporárias. Daí que as políticas de promoção de APLs dificilmente dariam causa a problemas nas instâncias da OMC. De todo modo, a análise do conteúdo dessas categorias revela que o Acordo é deveras rigoroso com

\footnotetext{
${ }^{33} \mathrm{O}$ termo "instalações existentes" significa instalações que tenham estado em uso por pelo menos 2 anos no momento em que as novas exigências ambientalistas sejam estabelecidas.

${ }^{134}$ Segundo o art. 8, §2 do Acordo: “A despeito do disposto nas PARTES III e V, os seguintes subsídios serão considerados irrecorríveis: (...) (b) assistência a uma região economicamente desfavorecida dentro do território de um membro, concedida no quadro geral do desenvolvimento regional 31 e que sela inespecífica (no sentido do Artigo 2) no âmbito das regiões elegíveis, desde que: (i) cada região economicamente desfavorecida constitua área geográfica continua, claramente identificada, com identidade econômica e administrativa definível; (ii) seja a região considerada economicamente desfavorecida a partir de critérios neutros e objetivos que demonstrem serem suas dificuldades originárias de outros fatores além de circunstâncias temporárias; tais critérios serão claramente expressos em lei, regulamento ou outro documento oficial, de forma a permitir-lhe a verificação; (iii) os critérios incluirão medida do desenvolvimento econômico baseada em pelo menos um dos seguintes fatores - renda per capita ou renda familiar per capita ou Produto Nacional Bruto per capita, que não deverá ultrapassar 85 por cento da média do território em causa; - taxa de desemprego, que deverá ser pelo menos 110 por cento da média do território em causa, apurados por um período de três anos; tal medida, porém, poderá resultar de uma composição de diferentes fatores e poderá incluir outros não indicados acima."
} 
os países em desenvolvimento porque impõe sérios obstáculos a adoção de políticas industriais mais agressivas ${ }^{135}$.

Já no "Acordo sobre Subsídios e Medidas de Investimentos Relacionadas ao Comércio", que trata das exigências que os países membros da OMC não podem fazer às empresas interessadas em neles investir, subsídio aparece como um instrumento cujo emprego exige a observância a certos limites. Assim é que o Estado que pretanda atrair investimentos não pode condicionar a concessão de subsídios à utilização de produtos de fabricação nacional no processo produtivo ou restrição de produtos importados a um percentual dos produtos nacionais. Obviamente que tal regra limita bastante a formulação de estratégias de desenvolvimento industrial que se pautem pelo estabelecimentos de condicionantes, visando atrair firmas que possam contribuir para o adensamento de cadeias produtivas no país.

Um exemplo de utilização da subvenção como maneira de incentivo às ações coletivas no âmbito de um APL pode ser extraído da experiência desenvolvida pela Empresa de Assistência Técnica e Extensão Rural do Estado de Minas Gerais (EmaterMG). A estatal destina um subsídio referente ao preço do litro do leite não aos produtores, mas às associações em que eles se congregam, como incentivo à prestação de serviços de inspeção e controle prévio da qualidade do produto dos associados. A entidade pode utilizar os recursos recebidos em ações de interesse dos filiados. Em caso de

\footnotetext{
${ }^{135}$ Veja-se o comentário de Rabih Ali NASSER: “A restrição do uso dos subsídios, que é o objeto contral do acordo, é claramente uma forma de restrição da liberdade dos países integrantes do SMC [Sistema Mundial de Comércio] de adotar políticas de desenvolvimento. Ora, esse efeito causa maior impacto nos países em desenvolvimento que são (...) os que mais dependem de políticas governamentaiis para alcançar maiores níveis de desenvolvimento. Em economias de mercado mais desenvolvidas, que prescindem de uma interferência governamental mais efetiva, uma tal restrição da liberadade tem um impacto menor. Portanto, a restrição da 'liberdade de desenvolvimento' que atige um maior grau os países menos desenvolvidos, tende a perpetuar a desigualdade, o que contraria os objetivos declarados do SMC. Além disso, a desigualdade hoje existente influencia a efetividade das normas do acordo. Esta efetividade tende a ser maior no que se refere aos países menos desenvolvidos. Isso porque a capacidade de mobiliação de recursos materiais e humanos necessários ao acompanhamento das políticas comerciais dos integrantes do SMC é muito maior nos países desenvolvidos. $O$ interesse em realizar tal acompanhaento, com o intuito de verificar o uso que os demais países têm feito de subsídios, também é maior para eles. $O$ maior interesses decorre do fato de que a produção e exportação de bens manufaturados, de maior valor agregado e com conteúdo tecnológico mais sofisticado, está bastante concentrada nesses países. Portanto, interessa-lhes impedir que outros países tornem-se competitivos (utilizando-se de instrumentos 'ilegais') nesses mesmos setores. O zelo pela aplicação do Acordo sobre Subsídios, com os limites que estabelece, é-lhes um instrumento importante na busca desse objetivo. Daí seu 'interesse' em utilizar sua 'capacidade de ação' para garantir a aplicação do acordo sempre que seus interesses econômicos estiverem ameaçados" em A OMC e os Países em Desenvolvimeto. São Paulo: Aduaneiras, p. 184
} 
descumprimento dos padrões de qualidade estabelecidos pelos associados, a subvenção à associação é suspensa ${ }^{136}$.

\subsubsection{Doação e concessão de bens públicos}

No que toca à outorga de bens de propriedade estatal, principalmente os imóveis, ela é muito frequente como medida de atração de empresas por parte de Estados e Municípios, os quais podem se valer da doação pura e simples, da concessão de uso ou da concessão de direito real de uso.

A doação de bem imóvel exige, em princípio, autorização legislativa e licitação ${ }^{137}$, apesar o Supremo Tribunal Federal já ter decido que Estados e Municípios podem alienar bens imóveis sem a instauração do certame ${ }^{138}$. Já a doação de bens móveis não exige a edição de lei autorizativa ${ }^{139}$. A particularidade desse instituto em face dos outros dois acima citados é que ele implica a efetiva transferência da propriedade em favor do $\operatorname{particular}^{140}$.

Já a concessão de uso e a concessão de direito real de uso são muito semelhantes. Em verdade, elas são de todo idênticas, ressalvada a possibilidade de se gravar a delegação do bem público como um direito real. Trata-se de um contrato pelo qual o particular adquire o direito de explorar um bem público em caráter privativo, nos termos estabelecidos pelo ente concedente (inclusive no que toca à eventual remuneração a ser arcada pelo particular). O Decreto-lei n. ${ }^{\circ}$ 271/67, estabelece expressamente que a utilização da concessão de dirieto real de uso se presta a "regularização fundiária de interesse social, urbanização, industrialização, edificação, cultivo da terra, aproveitamento sustentável das

${ }^{136}$ ALVES, Tiago R. Estudo de caso: O papel do cooperativismo no desenvolvimento regional sustentável e no surgimento de um Arranjo Produtivo Local (APL) do setor leiteiro. Disponível em http://www.biblioteca.sebrae.com.br/bds/BDS.nsf/4CD7E56B66FE76C1032571E80044B79B/\$File/NT0003 222A.pdf. Acesso em 20/12/2009.

${ }^{137}$ Veja-se o conteúdo da Lei n. ${ }^{\circ} 8.666 / 93$ a esse respeito: “Art.17. A alienação de bens da Administração Pública, subordinada à existência de interesse público devidamente justificado, será precedida de avaliação e obedecerá às seguintes normas: I- quando imóveis, dependerá de autorização legislativa para órgãos da administração direta e entidades autárquicas e fundacionais, e, para todos, inclusive as entidades paraestatais, dependerá de avaliação prévia e de licitação na modalidade de concorrência (...)".

${ }^{138} \mathrm{Na}$ Ação Direta de Inconstitucionalidade 927-3 RS o Supremo Tribunal Federal decidiu, em caráter liminar, com efeitos subsistentes até o momento, que o art. 17, I, da Lei 8.666/93 não se aplica aos Estados e Municípios no tocante à necessidade de instauração do certame.

${ }^{139}$ Art. 17, II da Lei n. ${ }^{\circ} 8.666 / 93$.

${ }^{140}$ Para um amplo tratamento a respeito das possibilidades de utilização de bens públicos por particulares ver MARQUES NETO, Floriano P. Bens Públicos: Função social e exploração econômica. Belo Horizonte: Fórum, 2009. 
várzeas, preservação das comunidades tradicionais e seus meios de subsistência ou outras modalidades de interesse social em áreas urbanas" (art. $7^{\circ}$, caput). A necessidade de lei autorizativa ou licitação depende do quanto disposto na legislação de cada ente federativo. Apesar de o Decreto-lei n. ${ }^{\circ}$ 271/67 sequer obrigar a definição de um prazo para a concessão de direito real de uso, sua adoção como instrumento de política de desenvolvimento produtivo exige que se atrele o aproveitamento pelo particular apenas enquanto ele cumprir com os motivos que ensejaram a outorga. Nesse sentido, o art. $7^{\circ}, \S$ $3^{\circ}$, estabelece que "[r]esolve-se a concessão antes de seu têrmo, desde que o concessionário dê ao imóvel destinação diversa da estabelecida no contrato ou têrmo, ou descumpra cláusula resolutória do ajuste, perdendo, neste caso, as benfeitorias de qualquer natureza". A concessão, seja a comum, seja a de direito real, parece atender tanto aos intereses dos particulares (que demandam o mínimo de estabilidade no vínculo com o Estado), quanto do poder público, eis que ele pode tomar o bem de volta em caso de inobservância dos termos de seu uso ${ }^{141}$.

Além desses instrumentos que permitem ao particular explorar um bem de propriedade estatal, o incentivo público pode incluir até mesmo a realização de obras prévias à instalação da planta industrial ou mesmo a construção da estrutura básica. Menos comum, porém, juridicamente viável, é o fornecimento de bens móveis arcado pelo poder público, como água ou energia elétrica. Tais benefícios podem ser condicionados ou não ao adimplemento de determinados encargos, tal como a geração de um determinado número de empregos ou a instalação da planta industrial num lapso temporal especificado. A prática das políticas industriais municipais e estaduais indicam que as condições da outorga de bens ou direitos reais decorrem sobretudo de um processo de negociação com os agentes beneficiados (e de disputa com outros entes federados ${ }^{142}$ ), de forma que dificilmente existem critérios normativos previamente definidos.

De todo modo, a outorga de direitos sobre imóveis públicos é especialmente útil na formação de cooperativas, incubadoras de empresas, distritos industriais e parques tecnológicos - empreendimentos esses que dependem especialmente da utilização de

\footnotetext{
${ }^{141}$ Maria Sylvia Zanella DI PIETRO assinala que a concessão de uso "é a forma mais recomendável nas utilizações privativas com empresa (ou seja, naquelas que envolvem penetração no solo e subsolo, ou, pelo menos, instalações mais onerosas) e naquelas que exigem empreendimentos de grande vulto, por isso mesmo mais custosas para o concessionário" em "A Gestão Jurídica do Patrimônio Imobiliário do Poder Público". Cadernos da FUNDAP, São Paulo, ano 9, n. 17, dez. 1989, p. 63.

${ }^{142}$ Vide tópico 2.1.4 acima sobre guerra fiscal.
} 
espaço e que se afiguram importantes para instalação de empresas cuja proximidade implique num benefício ao processo produtivo.

A depender do modo pelo qual se instalam distritos industriais e parques tecnológicos, essas figuras podem ser caracterizadas como um APL. Se há mecanismos de seleção e estabelecimento de critérios de funcionamento das empresas instaladas, de modo que as atividades desempenhadas pelas firmas tenham complementariedades - ex: utilização conjunta de laboratórios, estrutura de logística, gestão de compras e estoques - a proximidade criada pelos parques tecnológicos e distritos industriais pode ensejar a formação de um Arranjo.

\subsubsection{Financiamento em condições favoráveis}

Juntamente com a desoneração tributária, esse instrumento de fomento ${ }^{143}$ é o que recebe maior atenção dos agentes privados porque é o que tem resultados mais destacados e imediatos sobre a atividade econômica. O crédito barato, em qualquer lugar do mundo, é um bem muito importante para o êxito de qualquer empreendimento; no Brasil, a importância do acesso a tal utilidade cresce enormemente em razão do elevado preço do dinheiro no sistema bancário privado em comparação aos padrões internacionais. Além do custo do principal insumo da atividade econômica, outro fator que impele as empresas a buscar o sistema financeiro público é a aversão do sistema privado a alocar recursos em projetos de longa maturação e maior risco. Daí a fundamental importância do sistema de bancos e agentes financeiros públicos - por vezes chamados de bancos de desenvolvimento $^{144}$ - bem como de outros mecanismos de financiamento subsidiados, ainda que executados por bancos privados por força de lei (isto é, a legislação obriga os bancos privados a direcionarem um percentual dos recursos neles depositados ao financiamento de determinadas atividades ${ }^{145}$ ).

143 Marcos Juruena SOUTO denomina essa espécie de fomento como "empréstimos em condições
favoráveis" cf. "Estímulos positivos", op. cit, p. 140 .
${ }^{144}$ Segundo Fábio NUSDEO, bancos de desenvolvimento são "instituições especializadas, a operarem o
crédito de longo prazo direcionado, como forma não apenas de promover, mas também de orientar e de
racionalizar o processo de desenvolvimento, inclusive pela correção de suas próprias distorções. O banco de
desenvolvimento é assim uma instituição destinada a gerir o crédito concebido como instrumento de política
econômica, particularmente aquele voltado para as aplicações de longo prazo destinadas a introduzir
aquealas modificações estruturaus reclaadas pelo mesmo processo de desenvolvimento". Cf. "Bancos de
Desenvolvimento", verbete da Enciclopédia Saraiva do Direito. São Paulo: Saraiva, v. 10, pp. $247-249$.
145 Estima-se que mais de um terço do volume total de crédito no país seja formado por mecanismos de
direcionamento. Várias normas obrigam a aplicação dos recursos de depósitos em bancos privados em favor 
$\mathrm{O}$ arcabouço institucional voltado a tal atividade é composto pelos bancos federais e pelas agências estaduais de desenvolvimento, além da competência do Conselho Monetário Nacional $(\mathrm{CMN})$ para normatizar a matéria. A origem dos recursos empregados por esses sistemas de financiamento é orçamentária, da própria instituição financeira ou de fundos públicos por elas administrados.

O mecanismo jurídico pelo qual o financiamento se concretiza é relativamente simples: contratos de mútuo, cujo caráter fomentador pode se expressar na taxa de juros abaixo dos valores de mercado e no prazo dilargado de pagamento do empréstimo, o que pode incluir generosos períodos de carência. Em alguns casos, pode haver conjugação desse mecanismo com a subvenção, de modo que o beneficiado receba parte dos recursos a fundo perdido e, parte, a título de empréstimo. O prazo de carência, de pagamento e as taxas de juros podem variar de acordo com o interesse no desenvolvimento da atividade, suas características, bem como conforme a capacidade de pagamento do beneficiado. Assim é que o financiamento para pequenas empresas investirem em inovação tecnológica chega a ter juro zero e prazos de carência e amortização extendidos, pois, do contrário, o risco associado à atividade, somado à presumidamente pequena robustez econômica, afastaria as empresas da atividade.

\subsubsection{Bancos federais}

Todos os bancos públicos federais ${ }^{146}$ possuem diversas linhas de crédito que podem ser caracterizadas como ações de fomento, eis que as condições de pagamento dos empréstimos costumam ser mais favoráveis vis a vis as praticadas pelos bancos privados. Independente de os bancos federais possuírem linhas de crédito outras que não os identifiquem como instituições de fomento (v.g, crédito a pessoa física, cheque-especial), eles não podem deixar de possuír atuação incisiva em políticas de incentivo porque são

de determinados fins $(25 \%$ dos depósitos à vista em empréstimos rurais a taxas fixadas pelo Conselho Monetário Nacional, conforme o Manual do Crédito Rural, editado por Resolução do CMN com base na Lei n. ${ }^{\circ} 4.595 / 64 ; 65 \%$ dos recursos captados em caderneta de poupança para o financiamento imobiliário, sendo $80 \%$ desse montante no âmbito do Sistema Financeiro da Habitação, com taxas de juros limitadas pelo CMN, nos termos da Resolução 3.347 do CMN; $2 \%$ dos depósitos captados a vista para o microdrédito, com taxas limitadas a $4 \%$ - Resolução 3.442/06 , baseada na Lei n. ${ }^{\circ}$ 10.735/03. Confira-se a esse respeito TORRES FILHO, Ernani T. "Crédito Direcionado e Direcionamento do Crédito: Situação Atual e Perspectivas". Revista do BNDES, Rio de Janeiro, v. 13, n. ${ }^{\circ}$. 25, jun. 2006. pp. 35-50

${ }^{146}$ Atualmente, vinculam-se à União o BB, Caixa Econômica Federal (CEF), BNDES, BNB e BASA. 
instrumentos da política econômica governamental, ou, como dispõe o art. 22, caput da Lei 4.595/64, "são órgãos auxiliares da execução da política de crédito do Governo Federal".

Conquanto algumas leis lhe confiram missões específicas, os bancos públicos não possuem atuação muito bem delineada, podendo ela variar conforme a conjuntura; de todo modo, já se tem estabelecida certa tradição institucional que chega até mesmo a influenciar a legislação mais recente.

O grande agente desse setor, em termos de volume de crédito concedido, é o BNDES, que possui uma ampla gama de atuação, em diversos setores e em favor de empresas de todos os tamanhos, sejam elas estatais ou privadas; todavia, seu papel principal é o de fornecer crédito a longo prazo para empreendimentos que exigem montantes significativos de recursos - razão pela qual o banco é conhecido como o grande financiador da atividade produtiva brasileira ${ }^{147}$. Vale destacar que as taxas de juros utilizadas pelo banco (Taxa de Juros de Longo Prazo) são objeto de especial tutela pelas autoridades de política econômica brasileira ${ }^{148}$. O BNDES conta com uma subsidiária voltada especificamente ao financiamento de máquinas e equipamentos (FINAME) e outra destinada precipuamente a exercer participações societárias em empresas estatais e privadas (BNDESPar).

O BNDES financia também determinados programas em favor de Estados e Municípios. O Banco do Brasil, por sua vez, tem uma destacada ação no crédito agrícola, enquanto a Caixa Econômica Federal se sobressai no crédito habitacional e no setor de saneamento básico. O Banco do Nordeste e o Banco da Amazônia comungam a característica de, em decorrência de lei e cláusula estatutária, atuarem em área geográfica restrita, de modo que eles compõem o instrumental das políticas regionais da porção do território a que estão circunscritos ${ }^{149}$.

\footnotetext{
147 Originariamente, o banco foi concebido como financiador das empresas estatais. Esse papel é bem expresso na Lei n. ${ }^{\circ}$ 4.595/64, que estabelece que "o Banco Nacional do Desenvolvimento Econômico é o principal instrumento de execução de política de investimentos do Governo Federal, nos termos das Leis número 1628, de 20/06/1952 e 2973, de 26/11/1956" (art. 23).

148 De acordo com a Lei n. ${ }^{\circ}$ 9.365/98, o CMN deve ficar a a Taxa de Juros de Longo Prazo (TJLP) trimestralmente (art. $2^{\circ}$ ), De acordo com o Manual da TJLP, editado pelo BNDES, o custo financeiro total do mutuário do banco é dado pela TJLP acrescida de um spread básico (que varia de acordo com o estabelecido nas Políticas Operacionais do Sistema BNDES) e de um spread de risco (que varia de acordo com a classificação de risco do cliente). Nas operações indiretas o spread de risco é substituído pela comissão do Agente Financeiro, e acrescido da taxa de intermediação financeira.
}

149 Cf. nota de rodapé n. ${ }^{\circ} 78$. 


\subsubsection{Agências estaduais de fomento}

Os Estados, atualmente, contam com instituições que não se qualificam propriamente como bancos, mas são aptas a disponibilizar crédito ao setor produtivo.

Até meados dos anos 1990, praticamente todos os Estados da federação contavam com bancos dos quais eram os acionistas controladores. Contudo, a partir de 1996, com o Programa da Incentivo à Redução da Presença do Estado na Atividade Bancária (PROES), os Estados foram estimulados a transferir à União os seus bancos. Para que essa medida não tolhesse em absoluto a possibilidade de políticas públicas estaduais de fomento financeiro, permitiu-se que cada Estado contasse com uma única agência de desenvolvimento $^{150}$. Todavia, essas instituições não podiam captar depósitos, tampouco ter acesso ao redesconto do Banco Central nem possuir conta de reserva bancária. Suas fontes de recursos seriam o orçamento público, os fundos constitucionais ou as entidades de fomento nacional ou internacional, figurando como repassadoras de recursos, nesse último caso $^{151}$.

Recentemente, porém, no bojo do pacote das medidas anticíclicas ensejado pela crise financeira iniciada em 2008, o Conselho Monetário Nacional atribuiu às agências estaduais de fomento mais algumas competências ${ }^{152}$.

Em relação às fontes de financiamento, elas podem agora captar depósito interfinanceiro vinculado a operações de microfinanças (DIM). No que pertine propriamente às ações de fomento, elas ficam autorizadas a: financiar capitais fixos e de giro associado a projetos; prestar garantias; serviços de consultoria, de agente financeiro e de administrador de fundos de desenvolvimento; aplicar disponibilidades de caixa em títulos públicos federais; ceder créditos; adquirir, direta ou indiretamente, inclusive por meio de fundos de investimento, créditos oriundos de operações compatíveis com seu objeto social; ter participação acionária, direta ou indireta, no País, em instituições não financeiras, desde que não se configure a condição de acionista controlador, e que a empresa não seja controlada, direta ou indiretamente, por ente federativo, ou dele receba influência; realizar swap para proteção de posições próprias; realizar operações de crédito

\footnotetext{
${ }^{150}$ Para um histórico e descrição do funcionamento do PROES, ver SALVIANO JUNIOR, Cleofas. Bancos Estaduais: dos Problemas Crônicos ao Proes. Brasília, Banco Central do Brasil, 2004.

${ }^{151}$ Vide Resolução 2347/96, 2574/98 e 2828/01 do Conselho Monetário Nacional. A respeito do processo de criação das agências estaduais de fomento, Vide RIBEIRO, Paulo Antônio Agências de fomento - ambientes institucional, legal e operacional. N. Revista da Desenbahia, Salvador, vol. 1, set. 2004.

${ }^{152}$ Vide Resolução 3757/09 CMN.
} 
rural, financiar o desenvolvimento de empreendimentos de natureza profissional, comercial ou industrial, de pequeno porte, inclusive a pessoas físicas; realizar operações específicas de câmbio autorizadas pelo BC; realizar operações de arrendamento mercantil financeiro: i) contratadas com o próprio vendedor dos bens ou com pessoas jurídicas a ele vinculadas; e/ou ii) com recursos provenientes de instituições públicas federais de desenvolvimento.

Enfim, é uma gama significativa de instrumentos, os quais, se devidamente aplicados, podem concretizar o que já foi sugerido como um banco de APLs ${ }^{153}$. Segundo essa proposta de criação de uma instituição financeira específica para a promoção de clusters, o papel do banco não se limitaria ao financiamento. Para que este se desse em condições apropriadas e fosse eficaz no papel de promover o desenvolvimento local, o banco de APLs agiria de modo a reduzir a assimetria de informação em face das empresas financiadas, bem como promover diversos aspectos das atividades por elas exercidas por meio de ações de exame das possibilidades de restrutução das relações de produção locais, prospecção de investidores e realização de contatos com agentes capazes de promover a exportação da produção local. Em suma, tratar-se-ia de uma agencia de desenvolvimento que reuniria alguns dos principais instrumentos do fomento ao desenvolvimento produtivo.

\subsubsection{Uma propostas para financiamento de APLs a partir do modelo mexicano}

Outra proposta de criação de instrumentos de fomento financeiro aplicáveis a Arranjos Produtivos Locais advém do modelo mexicano de financiamento de micro, pequenas e médias empresas (MPMEs), "Programa de Desenvolvimento de Provedores". Ele se presta, sobretudo, a garantir crédito às empresas forncedoras de empresas líderes em Arranjos verticalizados ${ }^{154}$.

Segundo essse sistema, as MPMEs, com no mínimo dois anos de atividade, que apresentem um contrato ou ordem de serviço para fornecimento de produtos ou serviços a uma empresa de grande porte ou intituição de governo, tem acesso a crédito em taxas semelhantes às concedidas às empresas líderes. O barateamento do crédito se deve à

\footnotetext{
153 "Uma nova iniciativa para fortalecer as economias locais: o banco de arranjos produtivos" em, LASTRES, Helena; ALBAGLI, Sarita; SZAPIRO, Marina. Interagir para competir: promoção de arranjos competitivos e inovativos no Brasil. Brasília: Sebrae-Finep-Cnpq.

${ }^{154}$ Essa proposta é apresentada em PUGA, Fernando P. Alternativas de apoio a MPMEs localizadas em Arranjos Produtivos Locais. Rio de Janeiro: BNDES, 2003. (Textos Para Discussão, 99), pp. 25-26 e em CARARRO, Antônio F. Apresentação "Crédito e instrumentos financeiros para APLs" no Seminário "Arranjos produtivos locais como instrumento de desenvlovimento", do BNDES. Rio de Janeiro: 2004. Disponível em www.bndes.gov.br/SiteBNDES/export/sites/ default/bndes_pt/.../ap19.pdf.
} 
equiparação do risco do empréstimo às MPMEs à do risco das grandes empresas, eis que os contratos apresentados demonstrariam a existência de recebíveis que podem ser usados como garantia da operação.

O sistema mexicano conta também com sistema de difusão de informações relativas ao crédito, uma espécie de banco de dados dos fornecedores das empresas líderes que permite às MPMEs cadastrarem os contratos celebrados e oferece-los em garantia a instituições financeiras conectadas on line ao sistema. Desse modo, reduz-se a assimetria de informações entre instituição financeira e o tomador de empréstimo. Com o registro do contrato, as firmas anunciam, via on line, a demanda por crédito às instituições financeiras cadastradas nesse banco de dados, iniciando-se um leilão reverso de taxas de juros. Ou seja, a MPME pode consultar, instantânea e concomitantemente, as condições de empréstimo de um grande universo de instituições financeiras, cabendo a e escolha da proposta que for mais conveninente. Depois disso, o sistema fecha a operação, realizando a transferência dos direitos sobre os recebíveis, comunicando a empresa líder a que se vinculou a MPME.

Esse sistema mexicano certamente exige um investimento significativo em estrutura de TI, campanhas de sensibilização, senão mesmo mecanismos coercitivos, via regulação, para que as instituições financeiros adiram a ele. Contudo, no Brasil, como marco inicial, ele poderia ser intentado ao menos pelas instituições públicas de fomento financeiro em APLs selecionados, cadastrando-se as firmas deles participantes.

\subsubsection{Participação em empresa privada}

A participação estatal em empresas privadas aparece sempre de maneira próxima aos instrumentos de concessão de crédito porque não raras vezes os bancos públicos atuam com aporte de recursos que implicam a aquisição da participação societária de empresas incentivadas. Esse instrumento tem o condão de viabilizar aporte de capital concomitantente à obtenção de maior controle da operação da empresa, bem como a eventual percepção de dividendos ${ }^{155}$; de outro lado, é de se destacar que ele traz a desvantagem de fazer o Estado assumir ao menos parte dos riscos do negócio. A

\footnotetext{
${ }^{155}$ Em alguns casos, a participação societária não significa um incentivo, mas é instrumento de controle do Estado. No processo de privatização da Vale do Rio Doce e da Embraer, a União prosseguiu na condição de acionista minoritária das empresas, detendo uma ação de classe especial (golden share) que lhe confere poder de veto em decisões atinentes à alteração do objeto social e demais assuntos estratégicos dessas empresas.
} 
participação societária também pode advir da conversão de valores mobiliários (usualmente debêntures) emitidos pelas empresas e subscritos pelos bancos de fomento. $\mathrm{Na}$ esfera federal, esse papel é cumprido principalmente pela BNDESPar, subsidiária do BNDES que se destina justamente a deter as participações societárias do banco ${ }^{156}$. A participação societária estatal em empresa privada também figura como um dos instrumentos de financiamento das atividades de inovação tecnoógica autorizados pela Lei de Inovação ${ }^{157}$ (a qual tem aplicabilidade apenas à União e às entidades federais; contudo, diversos Estados da Federação já editaram diplomas pertinentes ao tema com conteúdo bastante próximo à Lei n. $\left.{ }^{\circ} 10.973 / 04\right)$.

No âmbito dos APLs, esse instrumento tem aplicação mais restrita, vez que se afigura pouco provável que o Estado passe a participar de várias empresas numa mesma localidade. Essa medida demandaria uma considerável estrutura burocrática e o engajamento de recursos humanos significativos. Mais provável seria a participação em empresa cuja atividade, de algum modo, beneficie a totalidade do Arranjo. Isso poderia se dar, por exemplo, numa eventual empresa líder de um APL verticalizado, de forma que o fortalecimento dessa firma implicasse no estímulo à cadeia de fornecedores.

\subsubsection{Concessão de garantias creditícias}

Por concessão de garantias creditícias se entendam aqui todos os instrumentos de garantia de crédito que o Estado pode oferecer aos financiadores dos agentes privados. A existência desse mecanismo oportuniza a um universo significativo de empresas que não possuem ativos considerados adequados pelos agentes financeiros (seja em razão de seu valor insuficiente, seja por conta da natureza do bem disponível para tal fim), o acesso ao mercado creditício. Uma vez que os agentes financeiros passam a contar com maior certeza de que as obrigações dos credores serão honradas, passam então a oferecer crédito.

\footnotetext{
156 Para uma análise minudente da atuação do BNDES, veja-se o trabaho de Mario SHAPIRO, Novos parâmetros para a intervenção do estado na economia: persistência e dinâmica na atuação do BNDES em uma economia baseada no conhecimento. Doutorado em Direito, USP, 2009.

157،Art. 19. A União, as ICT e as agências de fomento promoverão e incentivarão o desenvolvimento de produtos e processos inovadores em empresas nacionais e nas entidades nacionais de direito privado sem fins lucrativos voltadas para atividades de pesquisa, mediante a concessão de recursos financeiros, humanos, materiais ou de infra-estrutura, a serem ajustados em convênios ou contratos específicos, destinados a apoiar atividades de pesquisa e desenvolvimento, para atender às prioridades da política industrial e tecnológica nacional. (....) $\S 2^{\circ}$ A concessão de recursos financeiros, sob a forma de subvenção econômica, financiamento ou participação societária, visando ao desenvolvimento de produtos ou processos inovadores, será precedida de aprovação de projeto pelo órgão ou entidade concedente." (Grifo nosso).
} 
A lógica de funcionamento do instituto é relativamente simples: na hipótese de o agente garantido vir a se tornar inadimplente em face dos seus financiadores, estes buscam seu crédito não no devedor principal, mas nas garantias ofertadas pelo Estado, o qual, por meio de uma entidade administrativa (normalmente um fundo, criado por uma instituição financeira pública), age como um avalista, razão pela qual esse instrumento é usualmente denominado de fundo de aval. Os fundos de aval também podem ser estruturados por instituições privadas (associações e cooperativas), sendo que o fomento estatal pode se concretizar no aporte de recursos do fundo dessas entidades que responde pela garantia. A concessão de garantias creditícias funciona, pois, como uma espécie de subvenção em condição suspensiva, um subsídio meramente potencial, mas que produz efeitos econômicos importantes, eis que possibilita um número considerável de financiamentos. Caso o fundo tenha que honrar o aval, pagando a intituição financeira em razão do inadimplemento do beneficiado, pode-se condicionar a satisfação da garantia ao ajuizamento da ação de cobrança em face do inadimplemente pela institiução financeira, revertendo-se o crédito recuperado ao fundo de aval.

A garantia normalmente não corresponde à integralidade do financiamento, sendo certo que, quanto maior for o percentual do crédito garantido, maior será o estímulo à sua contratação. Para a formação do patrimônio que responde pelo aval, normalmente se cobra uma taxa do beneficiário, sendo que, em instituições privadas como associações e cooperativas, essa taxa pode ser cobrada como uma espécie de contribuição periódica dos filiados em favor da entidade. Alguns fundos de aval públicos são geridos diretamente pelas instituições financeiras estatais, mas isso não é um padrão obrigatório. Nos casos das associações e cooperativas, elas podem operar com a instituição que lhes convier, conquanto os bancos federais e agências de fomento estaduais apareça como parceiros contumazes.

A grande vantagem desse instrumento é que ele não implica o dispêndio imediato do volume de crédito que faz circular, ou seja, ele demanda um investimento público relativamente pequeno vis a vis os efeitos que ele pode gerar na oferta de produtos financeiros em proveito dos agentes a quem o fomento se endereça. Isso porque o dispêndio público só ocorre quando o credor executa a garantia, o que se dá apenas ao ensejo do inadimplemento do agente garantido, sendo certo que esse fato, mesmo em situações de elevado índice de inadimplência, é exceção face ao universo de devedores beneficiários de programas de fomento, a grande maioria adimplemente. Ou seja, o Estado 
acaba por despender uma quantia relativamente pequena se comparada ao volume de crédito que prporciona. Mesmo na hipótese de ter de arcar com a satisfação do crédito do financiador, o Estado assume, posteriormente, a posição de credor, e pode tentar recuperar em face do devedor o que teve de despender. E reside nessa tarefa o maior inconveniente da adoção desse mecanismo: o risco de inadimplemento, eis que o Estado terá diante de si um devedor que figurou como beneficiado de uma política de fomento dessa espécie, justamente porque não possuía ativos de fácil disposição em montante suficiente. Ou seja, a cobrança será difícil.

Na esfera federal, é de se mencionar o Fundo Garantidor de Exportações (FGE ${ }^{158}$ ), e o Seguro de Crédito às Exportações, instrumentos fundamentais da promoção do comércio exterior. O FGE oferece aos exportadores e a seus financiadores cobertura de riscos comerciais e políticas em termos semelhantes aos praticados pelas agências internacionais de crédito. A Seguradora Brasileira de Crédito às Exportações, empresa privada que conta com a participação acionária de bancos públicos e privados brasileiros, administra um seguro em que assume o risco comercial das operações com prazo de até dois anos; acima de tal prazo, o risco comercial é assumido pelo FGE, que sempre cobre os riscos político e soberano, independente do prazo. O Comitê de Financiamento e Garantia das Exportações (Cofig), colegiado que integra a Câmara de Comércio Exterior (Camex) do MDIC, tem a competência de estabelecer parâmetros e condições da acesso ao Proex e ao FGE, bem como enquadrar os pleitos dos agentes privados ${ }^{159}$. Também o SEBRAE conta com programas de instituição de fundos de aval.

Já o Fundo Garantidor de Crédito ${ }^{160}$, é um mecanismo de proteção a titulares de créditos contra instituições financeiras. O FGC se constitui na forma de uma entidade privada, sem fins lucrativos, da qual obrigatoriamente devem fazer parte as instituições financeiras que recebem depósitos à vista, a prazo e em contas de poupança, e as associações de poupança e empréstimo. O Fundo garante a liquidez de depósitos em conta corrente, de forma que funciona como um estímulo à formação da poupança popular., conferindo garantia de saque principalmente ao pequeno poupador 161.

\footnotetext{
${ }^{158}$ Criado pela Lei 9.818/99.

${ }^{159}$ Cf. Decreto 4.993/04. Sobre o tema, ver MOREIRA, Sévulo V; Tomich, Frederico \& Rodrigues, Maria da Gloria. Proex e BNDES-Exim: construindo o futuro. Brasília. IPEA. 2006. Texto para Discussão.

${ }^{160}$ Resolução 2.197 do CMN

161 Segundo a Resolução 3.400 do CMN, são objeto da garantia proporcionada pelo FGC os seguintes créditos, limitados em até sessenta mil reais por pessoa, em face de cada instituição financeira: depósitos à vista ou sacáveis mediante aviso prévio, depósitos em conta corrente, depósitos para investimento, depósitos
} 
A Lei n. ${ }^{\circ}$ 12.807/09 autorizou a criação de fundos para garantias de risco de créditos para i) microempreendedores individuais, microempresas e empresas de pequeno porte; ii) empresas de médio porte e (iii) autônomos, na aquisição de bens de capital, iv) produtores rurais e cooperativas. Para contemplar essas três primeiras categorias foi criado o Fundo Garantidor de Investimento ${ }^{162}$.

Praticamente todas as agências estaduais de fomento contam com fundos de aval, os quais se mostram de fundamental importância para o sistema de crédito em benefício dos projetos de desenvolvimento regional.

Vale citar aqui a experiência da Associação de Garantia de Crédito da Serra Gaúcha, que reúne empresas com o propósito de constituição de um fundo de garantia de crédito - um fundo de aval - perante instituições financeiras ("Fundo de Risco Local”). As empresas associadas contribuem com a formação do caixa do fundo - o qual também conta com aporte de instituições públicas de fomento - e, enquanto adimplentes, em princípio, podem contar com o aval até um determinado limite. Entende-se que o acesso ao crédito por parte dos associados é facilitado não só pela existência do aval da Associação, mas também porque ela realiza uma triagem prévia, com critérios de análise de risco que se mostra por vezes até mais sofisticada que as realizadas pelos bancos. Isso porque ela leva em conta informações a respeito das características pessoais do postulante ao crédito que as instituições financeiras dificilmente têm condições de avaliar. Assim é que aspectos como a confiabilidade, seriedade e empenho na atividade produtiva exercida são de mais fácil apreensão por parte dos membros da associação. Portanto, os agentes financiadores consideram que a pré-aprovação do postulante pela associação é um dado relevante a ser considerado e que chega a se refletir nas condições do financiamento contratado.

em poupança, depósitos a prazo com ou sem emissão de certificado, depósitos mantidos em contas não movimentáveis por cheques destinadas ao registro e controle do fluxo de recursos referentes à prestação de serviços de pagamento de salários, vencimentos, aposentadorias, pensões e similares; letras de câmbio; letras imobiliárias; letras hipotecárias; letras de crédito imobiliário.

162 Esse fundo substituiu o Fundo de Garantia para Promoção da Competitividade - FGPC, de natureza contábil, criado pela Lei 9.531/99, vinculado ao Ministério do Desenvolvimento, Indústria e Comércio Exterior e gerido pelo Banco Nacional de Desenvolvimento Econômico e Social - BNDES, com a finalidade de prover recursos para garantir o risco das operações de financiamento realizadas pelo BNDES e pela Agência Especial de Financiamento Industrial - FINAME ou por intermédio de instituições financeiras repassadoras, destinadas a: (i) microempresas e empresas de pequeno porte e (ii) médias empresas que sejam exportadoras ou fabricantes de insumos que integrem o processo produtivo, ou de montagem e de embalagem de mercadorias destinadas à exportação. Após um início de operações bem sucedido, o fundo caiu em desuso pela demora do pagamento do aval às isntituições financeiras, que, em razão disso, deixaram de utilizá-lo. Sobre isso ver LOPES, Simone S., LAGOA JUNIOR José Carlos dos S. CARDOSO, Marcelo P. \& PICCININI, Maurício S. "Fundos de Garantia e Acesso ao Crédito das Micro, Pequenas e Médias Empresas. a Experiência do FGCP: Sucesso Ou Fracasso?’BNDES Setorial, Rio de Janeiro, n. 26, p. 3-24, set. 2007. 


\subsubsection{Desoneração tributária}

Cuida-se aqui das medidas destinadas a reduzir a incidência de tributação em determinadas atividades (tornando-as economicamente viáveis ou mais atrativas) ou produtos (fazendo diminuir seu preço final), conquanto o privilégio a determinadas práticas ou produtos mediante mecanismos tributários possa se dar mediante a oneração dos bens substitutos daqueles que se pretende privilegiar pela ação fomentadora. Isto é, ou se reduz a tributação sobre o produto incentivado ou se eleva os encargos tributários sobre produtos que com ele disputem posição no mercado. Essa categoria de fomento se exprime no simples exercício de competência tributária mediante o manejo das hipóteses definidoras dos fatos imponíveis (restringindo os eventos econômicos suscetíveis de tributação, ou mesmo declarando-se expressamente a isenção tributária) e das alíquotas correspondentes.

A doutrina tributarista costuma abordar a repercussão dos efeitos mercadológicos dos tributos pela categoria da extrafiscalidade ${ }^{163}$, a qual indica um caráter específico do manejo das exações, destinado, pois, não só a garantir a arrecadação (fiscalidade) mas a induzir determinados comportamentos. Algumas vezes o contexto de elaboração da norma tributária é suficiente para revelar seu intuito extrafiscal, fazendo-se nítido que é ensejado pelo atendimento de um interesse específico. Contudo, de algum modo, toda e qualquer configuração da incidência tributária tem repercussões que vão além de simplesmente estabelecer a quantidade de recursos que o Estado arrecadará, e acaba por refletir opções de política pública que podem privilegiar determinada atividade ${ }^{164}$.

$\mathrm{Na}$ Constituição, a desoneração tributária aparece sob a rubrica de incentivo fiscal atrelado ao desenvolvimento regional (art. 43, §2, III e art. $151, \mathrm{I}^{165}$ ), de forma que se

\footnotetext{
163 "Há extrafiscalidade quando o legislador, em nome do interesse coletivo, aumenta ou diminui as alíquotas elou as bases de cálculo dos tributos, com o objetivo principal de induzir os contribuintes a fazer ou deixar de fazer alguma coisa". CARRAZA, Roque A. Curso de Direito Constitucional Tributário. São Paulo: Malheiros, 20ª ed. 2004, p. 101.

${ }^{164}$ Nas palavras de Alfredo Augusto BECKER: “A principal finalidade de muitos tributos (...) não será a de um instrumento de arrecadação de recursos para o custeio das depesas públucas, mas a de um instrumento de intervenção estatal no meio social e na economia privada. Na construção de todos e cada tributo, nunca mais estará ausente o finalismo extrafiscal, nem será esquecido o fiscal. Ambos coexistirão sempre agora de um modo consciente e desejado - na construção jurídica de cada tributo apenas haverá maior ou menor prevalência neste ou naquele sentido, a fim de melhor estabelecer o equilíbrio econômico-social'. BECKER, Alfredo Augusto, Teoria Geral do Direito Tributário. São Paulo, Lejus, 1998, $3^{\text {a }}$ ed., p. 587-588.

165 “Art. 43. (....) $\S 2^{o}$ - Os incentivos regionais compreenderão, além de outros, na forma da lei: III isenções, reduções ou diferimento temporário de tributos federais devidos por pessoas físicas ou jurídicas" e "Art. 151. É vedado à União: I - instituir tributo que não seja uniforme em todo o território nacional ou que implique distinção ou preferência em relação a Estado, ao Distrito Federal ou a Município, em detrimento de outro, admitida a concessão de incentivos fiscais destinados a promover o equilíbrio do desenvolvimento sócio-econômico entre as diferentes regiões do País".
} 
reconhece a importância da redução dos tributos como instrumento de fomento à atividade produtiva. $\mathrm{O}$ art. $170, \mathrm{~V}$, por sua vez, ao autorizar "tratamento diferenciado conforme $o$ impacto ambiental dos produtos e serviços e de seus processos de elaboração e prestação" também parece indicar que a proteção ao meio ambiente tem estatuto diferenciado como critério de conformação da política tributária ${ }^{166}$. A desoneração fiscal como instrumento de desenvolvimento produtivo também está subjacente na instituição da Zona Franca de Manaus (ZFM) $)^{167}$.

Mais recentemente, a ideia de que a tributação figura como obstáculo à inserção competitiva da indústria brasileira no mercado global foi albergada na Lei n. ${ }^{\circ} 11.508 / 07$, que dispõe sobre o regime tributário, cambial e administrativo das Zonas de Processamento de Exportação (ZPE). Em suma, a ZPEs são áreas de livre comércio com o exterior, destinadas à instalação de empresas voltadas para a produção de bens a serem comercializados no exterior. Incluem-se nas vantagens às empresas instaladas nas ZPES a suspensão de tributos na aquisição de bens e serviços ${ }^{168}$ e a possibilidade de manter no exterior $100 \%$ das divisas obtidas nas suas exportações ${ }^{169}$. De fato, as empresas agraciadas com a desoneração ganham em competitividade externa, todavia, é de se discutir em que medida o restante da sociedade pode se beneficiar com esse expediente. Nesse sentido, é de se notar que as ZPEs não se prestam necessariamente à desconcentração regional da atividade industrial, pois, apesar de haver a prescrição de que devam ser instaladas em "regiões menos desenvolvidas" "170, os critérios para identificação dessas áreas não está claro. O risco maior é que se repita a experiência da ZFM, que pouco serviu para propiciar o desenvolvimento produtivo regional, tendo servido, quando muito, como simples instrumento de urbanização de Manaus; há de se cuidar, pois, para que não se repita os problemas da ZFM - a obstaculização do desenvolvimento de indústrias ao seu redor justamente porque confere vantagens fiscais excessivas, desestimulando a instalação de firmas fora de sua área, além da inexistência de mecanismos que garantam a integração das

\footnotetext{
${ }^{166}$ Para um tratamento detalhado sobre as possibilidades de emprego de mecanismos tributários em favor da proteção ambiental, vide OLIVEIRA SOUZA, Jorge Henrique de. Tributação e Meio ambiente. Belo Horizonte: Del Rey, 2009.

167 Art. 40 do ADCTs: "É mantida a Zona Franca de Manaus, com suas características de área livre de comércio, de exportação e importação, e de incentivos fiscais, pelo prazo de vinte e cinco anos, a partir da promulgação da Constituição."

168 Art. $6^{\circ}$-A da Lei 11.508/07.

${ }^{169}$ Art. 15, parágrafo único da Lei 11.508/07.

${ }^{170}$ Art. $1^{\circ}$, caput.
} 
empresas ali localizadas com a estrututra produtiva regional ${ }^{171}$. Trata-se de aspecto que merece exame especial dos órgãos destinados a aprovar os projetos de instituição das ZPEs, a Presidência da República ${ }^{172}$ e o Conselho Nacional das Zonas de Processamento de Exportação - $\mathrm{CZPE}^{173}$. No mais, a Lei n. ${ }^{\circ}$ 11.508/07 também não exige que a atividade ali desenvolvida seja baseada predominantemente em insumos nacionais, de forma que, no limite, as ZPEs podem se tornar simples "maquiadoras", plantas industriais que apenas importam insumos oriundos do restante do globo para serem montados aqui e retornarem ao mercado externo - segundo essa lógica, o único ganho efetivo da adoção das ZPEs seria a geração de empregos, o que pode ser muito pouco em comparação com a renúncia fiscal realizada. Por isso cabe também verificar em que medida a diretriz de "atendimento às prioridades governamentais para os diversos setores da indústria nacional e da política econômica global, especialmente para as políticas industrial, tecnológica e de comércio exterior"174, que deve nortear a análise de projetos pelo CZPE, restará observada.

O emprego de mecanismos de desoneração tributária, contudo, enfrenta alguns condicionantes de política fiscal. O principal entrave na utilização dessa ferramenta é o art. 14 da Lei de Responsabilidade Fiscal, que classifica a desoneração como renúncia de receita e estabelece como requisitos de aplicação da medida: (i) estimativa do impacto orçamentário-financeiro no exercício em que deva iniciar sua vigência e nos dois seguintes, atendimento ao disposto na lei de diretrizes orçamentárias e, alternativamente, (i.1) demonstração pelo proponente de que a renúncia foi considerada na estimativa de receita da lei orçamentária e não afetará as metas de resultados fiscais previstas no anexo próprio da lei de diretrizes orçamentárias; ou (i.2) acompanhamento de medidas de compensação, no período mencionado acima, por meio do aumento de receita proveniente da elevação de alíquotas, ampliação da base de cálculo, majoração ou criação de tributo ou contribuição. $\mathrm{O} \S 1^{\circ}$ do art 14 compreende na categoria de renúncia de receita, a "anistia, remissão, subsídio, crédito presumido, concessão de isenção em caráter não geral, alteração de alíquota ou modificação de base de cálculo que implique redução discriminada de tributos ou contribuições, e outros benefícios que correspondam a

\footnotetext{
${ }^{171}$ BERCOVICI, Gilberto, Desigualdades Regionais, Estado e Constituição. op cit, p. 135.

172 “Art. $2^{\circ}$ A criação de ZPE far-se-á por decreto, que delimitará sua área, à vista de proposta dos Estados ou Municípios, em conjunto ou isoladamente.".

173 “Art. $3^{\text {o }}$ Fica mantido o Conselho Nacional das Zonas de Processamento de Exportação - CZPE, criado pelo art. $3^{\circ}$ do Decreto-Lei $n^{\circ}$ 2.452, de 29 de julho de 1988, com competência para: I - analisar as propostas de criação de ZPE; II - aprovar os projetos industriais correspondentes, observado o disposto no $\S 5^{\underline{o}}$ do art. $2^{\underline{o}}$ desta Lei; e III - traçar a orientação superior da política das ZPE."

${ }^{174}$ Art. $3^{\circ}, \S 1^{\circ}$, III..
} 
tratamento diferenciado", sendo que, se a concessão ou ampliação do incentivo ou benefício decorrer da adoção de medidas de compensação, o benefício só entrará em vigor quando elas forem implementadas $\left(\S 2^{\circ}\right) . \mathrm{O} \S 3^{\circ}$, contudo, exclui da regra geral do art. $14 \mathrm{a}$ modificação das alíquotas de alguns impostos federais (incidentes sobre importação, exportação, produtos industrializados e operações financeiras), o que indica que uma das finalidades do dispositivo é restringir a guerra fiscal nos Estados e Municípios, ao passo que a União pode continuar a manejar os impostos que são aptos a reagir a alterações conjunturais da economia. Outro fator limitador à concessão de benefícios tributários no âmbito das políticas estaduais, já referido no tópico 2.1.5, é a Lei Complementar 24/75, cujo art. $2^{\circ}, \S 2^{\circ}$, exige aprovação unânime dos representantes dos Estados da Federação no Conselho Nacional de Política Fazendária (CONFAZ), de quaisquer incentivos ou favores fiscais ou financeiro-fiscais concedidos com base no Imposto de Circulação de Mercadorias e Serviços (ICMS), dos quais resulte redução ou eliminação, direta ou indireta, do respectivo ônus.

A desoneração tributária é um instrumento de difícil aplicabilidade em prol dos APLs; isso porque, afora as possibilidades de concessão de benefícios fiscais no âmbito das regiões administrativas referidas no art. 43 da Constituição da Repúbica (e sendo certo que dificimente há uma coincidência entre a área da região e área do APL, normalmente mais restrita), não se pode instituir desonerações tributárias em prol de de setores específicos instaladas numa área num perímetro delimitado. $\mathrm{Na}$ esfera estadual, caso isso fosse intentado, correria o risco de ser considerado atentatório à isonomia tributária e o benefício seria considerado ilícito. Isso não impede, contudo, que, caso as políticas estaduais visem incentivar um APL determinado, promova-se a desoneração das atividades que lhe concernem. $\mathrm{O}$ fato de essas mesmas atividades serem desoneradas em todo o território estadual, se não faz ressaltar uma vantagem competitiva específica, também não chega a ser prejudicial à localidade.

\subsubsection{Proteção tarifária e proteção comercial}

Ambas as formas aqui referidas dizem respeito ao modo pelo qual o Estado lida com a questão da competição que as empresas instaladas no seu território enfrentam das empresas estrangeiras e, em última análise, operam como garantias de existência e robustez dos mercados internos produtores e consumidores. Justamente por isso possuem 
complementariedades notadas, mas se articulam em instâncias diferentes, mediante instrumentos distintos. A proteção tarifária é uma forma de incentivo que se faz mediante a proteção da produção interna da competição internacional regular das firmas estrangeiras, isto é, em face da disputa mercadológica lícita, ao passo que por proteção comercial denominam-se aqui as ações tomadas contra ilícitos verificados no plano do comércio exterior que prejudiquem a produção nacional.

A proteção tarifária talvez essa seja a forma mais antiga de fomento econômico praticada pelas nações, sendo um dos pontos principais da política econômica mercantilista. Em suma, trata-se de limitar o acesso de produto estrangeiros ao mercado nacional, seja mediante o estabelecimento de quotas máximas de importação, seja mediante a aplicação de sobrepreços aos produtos importados com o fito de os tornar menos competitivos face aos produtos nacionais. Como já se destacou no item 1.2.1, a nova regulação do comércio internacional, sobretudo com o advento da OMC, tem mitigado o uso desses mecanismos na medida em que estabelece alguns parâmetros tarifários máximos cuja desobservância acarreta sanções ao país que delas faz uso; em regra, é igualmente proibido o estabelecimento de cotas máximas de importação, observadas algumas exceções (utilização de salvaguardas ${ }^{175}$, o que se dá necessariamente por um determinado período).

Sob a rubrica da proteção comercial podem-se albergar todos os instrumentos que visem impedir a prática de condutas consideradas ilegais nos tratados multilaterais de comércio exterior. Incluem-se nesse escopo as ações antidumping e contra subsídios ilegais (incluídas medidas compensatórias), o uso de salvaguardas (e o combate ao uso indevido do emprego de salvaguardas por outros países) e o combate à aplicação indevida de barreiras técnicas ${ }^{176}$.

Essas mecanismos são manejados pelas entidades federais considerendo a performance da economia nacional como um todo; isso é, não se restringem à proteção de uma dada região. Desse modo, a aplicabilidade deles em prol dos APLs é praticamente

\footnotetext{
175 "Salvaguardas são mecanismos excepcionais, previstos pelo ordenameno da OMC, por meio dos quais é conferida a um Membro a possibilidade de suspensão de suas obrigações, assumidas junto àquela Organização, durante um período limitado de tempo que se faz necessário para que esse Membro possa proteger sua economia ou seus produtores nacionais, que estão sofrendo ou em vias de sofrer algum tipo de prejuízo". BROGINI, Gilvan Daminiani. OMC e Indústria Nacional: as Salvaguardas para o Desenvolvimento. Aduaneiras: São Paulo, 2004, pp. 86-87 Como as salvaguardas representam uma inobservância temporária das regras de livre comércio, o seu uso indevido pode caracterizar um ilícito.

${ }^{176}$ Essas tarefas são reunidas no Departamento de Defesa Comercial da Secretaria de Comércio Exterior do MDIC.
} 
improvável, a não ser no caso de uma dada localidade acabar por aglutinar numa signficativo de empresas de um determinado setor da economia nacional que demanda a atuação do MDIC em matéria de proteção comercial.

\subsubsection{Compras governamentais}

O Estado figura como o principal agente consumidor de determinados produtos e serviços, sendo que, em alguns casos, ele acaba por exercer efetivo poder de mercado, capaz de influenciar fortemente os preços praticados e mesmo a quantidade de mercadoria produzida. $\mathrm{O}$ fato de se ter um consumidor com tais características pode se mostrar muito proveitoso como mecanismo de regulação de mercados ${ }^{177}$ em que o risco de demanda seja especialmente relevante para o desenvolvimento do setor. Essa garantia de demanda é também importante na instalação de cadeias produtivas mais sofisticadas e grandemente dependente de escalas, que podem ter no Estado comprador a garantia de um mercado com o tamanho que as viabilize. Não é sem motivo, pois, que os países de centro utilizem largamente esse instrumento de política industrial ${ }^{178}$. Com base na categorização proposta por Cássio Garcia SILVA, propõe-se a seguinte tipologia de modelos de compras governamentais:

(i) neo-schumpeteriano ${ }^{179}$ : setor público demanda de fornecedor um determinado bem ou serviço não existente no mercado, exigindo pesquisa e desenvolvimento do fornecedor local;

\footnotetext{
177 A regulação que seda por meio do exercício do poder de compra é também chamada de regulação operacional.

178 “Gersen afirma que a demanda do setor público de um país, dominada por objetivos sociais, políticos, estratégicos ou militares, pode estimular ou retrair a inovação em suas fronteiras e até mesmo puxar ou empurrar a inovação em certas direções. Assim, depreende-se que os autores de filiação teórica neoschumpeteriana dão destaque ao fato de que a estratégia de compras governamentais, dos órgãos e empresas públicas de um país, pode ser decisiva na conformação da capacidade inovativa de seu tecido produtivo, uma vez que disssipa muitas das incertezas inerentes à atividade inovativa, com as quais os empresário se depara quando decide se empenhar no desenvolvimento de um novo produto ou processo. A política de compras governamentais pode ser instrumento de política (do lado da demanda - demand side policy) de Ciência, Tecnologia e Inovaçao, o qual tem historicamente se notabilizado pela ação de estímulo a desenvolvimento de novos produtos em alguns países. Os casos de política de compras governamentais da Suécia e dos Estados Unidos são exemplos elucidativos disto". SILVA, Cássio Garcia. A Política de Compras de Entidades Públicas como Instrumento de Capacitação Tecnológica: o Caso da Petrobrás. Mestrado em Política Científica e Tecnológica. Unicamp, 2005.

${ }^{179}$ A expressão alude à corrente de teoria econômica que pretende atualizar as contribuições do pensamento de Joseph A. Schumpeter acerca da importância dos processos de ruptura e desequilíbrio provocados pela inovação para a compreensão do fenômeno do desenvolvimento ecoômico.
} 
(ii) transferência de tecnologia do usuário para o fornecedor local: o Estado transfere tecnologia de seus institutos de pesquisa para a empresa nacional, que se encarrega de sua produção. Era o modelo usado no sistema Telebrás pré-privatizaçao, no qual o CPqD se encarregava de desenvolver tecnologia e transferi-la para um fornecedor local.

(iii) transferência de tecnologia do fornecedor estrangeiro par o usuário: governo demanda de um fornecedor estrangeiro a concepção de uma tecnologia e, de posse dela, trespassa-a à empresa nacional para produção.

(iv) substituição de importações: Estado demanda de empresa nacional um produto cuja tecnologia, originalmente estrangeira, seja pública ou licenciável; e

(v) neutra (ou liberal): Estado figura como simples consumidor, adquirindo bens e serviços independente de sua nacionalidade. Busca-se somente o menor preço e/ou melhor qualidade, sem preocupações em relação ao desenvolvimento produtivo.

Essa tipologia não pode ser tomada como uma descrição estanque dos modelos de compras governamentais, pois os Estados nacionais podem se valer de todos esses modelos concomitantemente; tudo depende do que se busca em cada setor da economia em que o poder de compra governamental seja relevante. De qualquer modo, a adoção dos modelos "i” a "iv" implica um sobrepreço ao Estado, ainda que eventualmente temporário, com o qual o erário arcará por internalizar, ao invés de adquirir os bens e serviços via importação, a custo reduzido.

No Brasil, desde a edição da Lei de Inovação, o Estado pode demandar bens e serviços ao estilo do modelo "neo-schumpeteriano", pois o art. 20 do diploma ${ }^{180}$ autoriza a Administração a contratar empresa ou consórcios de empresas com o propósito de realizar atividades de pesquisa e desenvolvimento que envolvam risco tecnológico para solução de problema técnico específico ou obtenção de produto ou processo inovador.

\footnotetext{
180 “Art. 20. Os órgãos e entidades da administração pública, em matéria de interesse público, poderão contratar empresa, consórcio de empresas e entidades nacionais de direito privado sem fins lucrativos voltadas para atividades de pesquisa, de reconhecida capacitação tecnológica no setor, visando à realização de atividades de pesquisa e desenvolvimento, que envolvam risco tecnológico, para solução de problema técnico específico ou obtenção de produto ou processo inovador. $\S 1^{\circ}$ Considerar-se-á desenvolvida na vigência do contrato a que se refere o caput deste artigo a criação intelectual pertinente ao seu objeto cuja proteção seja requerida pela empresa contratada até 2 (dois) anos após o seu término. $\S 2^{\underline{o}}$ Findo o contrato sem alcance integral ou com alcance parcial do resultado almejado, o órgão ou entidade contratante, a seu exclusivo critério, poderá, mediante auditoria técnica e financeira, prorrogar seu prazo de duração ou elaborar relatório final dando-o por encerrado. $\S 3^{\circ}$ O pagamento decorrente da contratação prevista no caput deste artigo será efetuado proporcionalmente ao resultado obtido nas atividades de pesquisa $e$ desenvolvimento pactuadas."
} 
No mais, a Lei de Licitações e Contratos Administrativos contempla hipóteses autorizadoras da contratação direta, dispensando instauração do certame público, em incentivo a determinadas atividades - é o caso da "contratação de associação de portadores de deficiência física, sem fins lucrativos e de comprovada idoneidade, por órgãos ou entidades da Admininistração Pública, para a prestação de serviços ou fornecimento de mão-de-obra, desde que o preço contratado seja compatível com o praticado no mercado" (art. 24, XX) e da "na contratação da coleta, processamento e comercialização de resíduos sólidos urbanos recicláveis ou reutilizáveis, em áreas com sistema de coleta seletiva de lixo, efetuados por associações ou cooperativas formadas exclusivamente por pessoas físicas de baixa renda reconhecidas pelo poder público como catadores de materiais recicláveis, com o uso de equipamentos compatíveis com as normas técnicas, ambientais e de saúde pública" (art. 24, XXVII).

Também o Estatuto da Micro e Pequena Empresa (Lei Complementar n. ${ }^{\circ}$ 123/06) confere algumas vantagens competitivas a firmas de tal porte, quais sejam: prazo especial para a comprovação de regularidade fiscal da pequena ou microempresa na etapa de habilitação da licitação ( $\operatorname{art} 43, \S \S 1^{\circ}$ e $2^{\circ}$ ); empate ficto com a proposta da empresa de maior porte e possibilidade de redução do valor, isto é, se o valor da proposta da pequena ou microempresa for até $10 \%$ superior ao daquela, ou de $5 \%$ na modalidade de pregão, presume-se um empate e oportuniza-se à micro ou pequena empresa reduzir o valor oferecido pela melhor licitante (desde que não seja ela tamém micro ou pequeno empresa) (art. 44 e 45); emissão de cédula de crédito microempresarial pela micro ou pequena empresa que, sendo titular de crédito empenhado ou liquidado, não o receba em pagamento pela Administração em 30 dias, contados de sua liquidação, possibilitando a cessão do crédito a terceiros (art. 46 caput e parágrafo único); possibilidade de realização de licitações restritas à participação de pequenas e microempresas, com os objetivos cumulados de promover o desenvolvimento econômico e social no âmbito municipal e regional, elevar a eficiência das políticas públicas e incentivar a inovação tecnológica, bem como estender o tratamento diferenciado a licitações em que os editais exijam (arts. 47 e $48)^{181}$.

A Lei de Informática (Lei n. ${ }^{\circ} 8.248 / 91$, com alterações substantivas pela Lei n. ${ }^{\circ}$ 11.077/04), por sua vez, autoriza a Administração a restringir a licitação às empresas que

181. Cf. PEREIRA JR., Jessé Torres \& DOTTI, Marines Restelatto. Políticas Públicas nas Licitações e Contratações Administrativas. Belo Hozinte: Fórum, 2009 e JUSTEN FILHO, Marçal. O Estatuto da Microempresa e as Licitações Públicas. São Paulo: Dialética, 2007. 
observem o Processo Produtivo Básico aplicável à atividade. Vale citar, ainda, a iniciativa de várias prefeituras que têm favorecido produtores rurais locais nas licitações de fornecimento de merenda escolar ${ }^{182}$.

Mais recentemente, tem-se assistido à retomada desse instrumento de política industrial de maneira mais contundente. É de se citar a política de compras de navio do grupo Petrobrás em apoio à industria naval brasileira. No âmbito do Ministério da Minas e Energia, foi instituído o Programa de Mobilização da Indústria Nacional de Petróleo e Gás Natural (PROMIMP), que tem como objetivo aumentar a participação da indústria nacional de bens e serviços na implantação de projetos nas áreas de óleo e gás. No setor de fármacos, gesta-se um plano abrangente de parcerias entre o Ministério da Saúde e empresas públicas e privadas do setor de fármacos calcado, entre outros instrumentos, na demanda do SUS por medicamentos ${ }^{183}$.

\subsubsection{Incentivos na estrutura de preços regulados}

O fomento também se expressa na estrutura de preços que não são livremente formados no mercado, isto é, ele se dá em determinadas políticas de preços administrados, principalmente nas tarifas de serviços públicos. O mecanismo mais utilizado é o subsídio cruzado, o qual opera a "transferência de recursos obtidos num determinado segmento para outro, a fim de que o segmento beneficiado possa pagar valores mais baixos ${ }^{184, "}$. Esse segmento de uma estrutura de preços pode ser uma determinada categoria de usuários ou

182 CARVALHO, Daniela Gomes de. "Licitações sustentáveis, alimentação escolar e desenvolvimento regional: uma discussão sobre o poder de compra governamental a favor da sustentabilidade". IPEA, Planejamento e Políticas Públicas, n. ${ }^{\circ}$ 32, jan./jun. 2009.

${ }^{183} \mathrm{O}$ Decreto $\mathrm{s} / \mathrm{n}^{\mathrm{o}}$ de 12 de maio de 2008, que criou o Grupo Executivo destinado a formular o marco regulatório do Complexo Industrial da Saúde, estabelece que, dentre as diretrizes das normas a serem formuladas deve constar o "estímulo ao uso do poder de compra do Sistema Único de Saúde para favorecer a produção, a inovação e a competitividade no CIS" (art. 3º, IV). Cf. também Portaria n. ${ }^{\circ}$ 987/2008 do Ministério da Saúde, que lista os medicamentos e equipamentos considerados estratégicos para subsidiar o BNDES no apoio às operações de participação nos resultados do projeto, conforme estabelecido em seu Programa de Apoio ao Desenvolvimento do Complexo Industrial da saúde (PROFARMA),

184. Vale citar ainda a seguinte explicação sobre o mecanismo de subsídio cruzado: "Isoladamente considerada, essa prática representa uma distorção dos elementos econômicos envolvidos na prestação de um dado serviço público. A remuneração cobrada em cada segmento envolvido é, por assim dizer, alterada artificialmente em virtude do subsídio. No segmento do qual se extrai o subsídio, o valor cobrado é superior ao necessário, pois, além dos custos e da remuneração do prestador do serviço, há a parcela referente à transferência de recursos. O segmento beneficiado, por sua vez, pratica valores aquém do necessário para compensar os custos e a remuneração do operador, uma vez que tem sua equação econômica favorecida com o montante recebido". CÂMARA, Jacintho Arruda. "O regime tarifário como instrumento de políticas públicas". Revista de Direito Público da Economia - RDPE, Belo Horizonte: Fórum, ano 3, n. 12, out./dez. 2005, p. 107. 
pode ser indicado pela fruição de um padrão de consumo (ex: unidades de serviço -m3 de água tratada, MW/mês de energia elétrica).

O favorecimento de uma categoria de usuários se dá, por exemplo, quando idosos se beneficiam de descontos nas tarifas de transporte público; quando entidades de assistência social cadastradas são isentadas ou pagam preços subsidiados pelos serviços de abastecimento de água ou distribuição de energia elétrica; ou, ainda, quando se criam gradações de qualidade e preço do serviço prestado (ex: classes econômica, executiva e primeira classe dos serviços de transporte aéreo).

Essa lógica se aplica aos benefícios concedidos a estudantes e idosos em programas desportivos e culturais (meia-entrada); apesar de esses preços não serem, em princípio, objeto de regulação, entende-se que os objetivos ligados à disseminação da cultura autoriza esse tipo de intervenção estatal no mercado ${ }^{185}$, a qual se dá não propriamente na fixação de valores, mas na aplicação do percentual de desconto representativo do incentivo, que implica em fazer os demais consumidores do mesmo bem suportarem os custos $r$.

Mas, se a intenção é privilegiar a moderação do consumo de bens escassos (como pode se dar com a água, em determinados períodos), a estrutura tarifária pode beneficar usuários que apresentem consumo reduzido e penalizar os que extrapolem determinado padrão - o que se faz mediante a aplicação de descontos ou multiplicadores sobre a tarifa referencial, isto é, conforme o consumo aumenta, o preço da unidade de consumo também se eleva. A estrutura de incentivos também se pode revelar na manutenção de preços idênticos aplicáveis a usuários que desfrutem serviços cujos custos sejam distintos. Assim é que o preço do serviço pode não ser suficiente para cobrir os custos de seu oferecimento em determinadas localidades, de forma que, nesses casos, os grandes centros urbanos normalmente onde a rede de provimento dos serviços já está instalada e até mesmo amortizada e o custo de sua manutenção tende a ser mais baixo - acabam subsidiando a expansão da rede a regiões deles distantes. A prática de tarifas fixas, portanto, pode significar um importante instrumento de subsídio cruzado.

Outro exemplo de incentivos advindos de preços regulados se revela no Programa de Incentivo às Fontes Alternativas de Energia Elétrica - Proinfa ${ }^{186}$, pelo qual o Estado, visando incentivar a geração de energia eólica, de biomassa e de pequenas centrais

\footnotetext{
${ }^{185}$ Ver decisão do STF na Ação Direita de Inconstitucionalidade 1.950-3, referida no tópico 2.1.2.

${ }^{186}$ Lei n. $^{\text {o } 10.438 / 02}$ e Decreto n. ${ }^{\text {1 }} 10.541 / 02$.
} 
hidrelétricas, assegura um valor de compra, determinado por meio de ato administrativo, que viabilize a produção desse bem. Se a energia oriunda de tais fontes competisse livremente com outras fontes, mais baratas, não seria produzida porque sua comercialização seria inviável. Para bancar o incentivo, são repassados à Eletrobrás recursos auferidos de todas as classes de consumidores do sistema interligado nacional de energia elétrica, à exceção dos classificados como baixa renda residencial ${ }^{187}$. Nesse exemplo do Proinfa, como Estado figura como comprador da energia incentivada, pode-se dizer que essa espécie de fomento se confunde com o instrumento das compras governamentais tratado logo acima.

\subsubsection{Apoio institucional e assistência comercial}

Por apoio institucional e assistência comercial entender-se-á aqui toda sorte de iniciativa destinada a promover o bom manuseio de informação e conhecimento envolvido no processo produtivo. Em suma, trata-se de incrementar o capital humano dos agentes envolvidos na atividade fomentada bem como de fornecer informações que possam contribuir com o desenvolvimento da atividade, seja na forma de treinamento, na instrução de uso de tecnologias de produção, seja no apoio à administração do negócio ou mesmo ajuda na comercialização de bens em situações nas quais haja dificuldade de se chegar ao mercado consumidor potencial das firmas incentivadas.

Essa espécie de atuação é bastante abrangente e tem forte interface (senão mesmo identidade, em alguns casos) com as políticas educacionais. Essa vinculação com as políticas de educação é evidente em iniciativas como o oferecimento de cursos técnicos profissionalizantes ou de capacitação profissional, mas não é refratária a programas de treinamento e capacitação de pequenos e médios empresários, tais como os promovidos por entidades do Sistema S. Em último caso, trata-se de oportunizar a transmissão de conhecimento - medida deveras relevante num país com um trágico déficit educacional que atinge todos os estratos sociais e, portanto, implica severas perdas de oportunidade e prejuízos de toda sorte na totalidade do sistema produtivo.

187 A Resolução 166/05 da Agência Nacional de Energia Elétrica estabelece como o cargo setorial do PROINA deve ser repassado à tarifa de energia elétrica. Segundo o art. 17 desse diploma a tarifa de uso dos sistemas de distribuição do PROINFA "será definida em $R \$ / M W h$ e obtida pela razão entre o custo total do Programa, estabelecido no respectivo Plano Anual do PROINFA - PAP, e o mercado total de energia, em MWh, excluído o consumo nos Sistemas Isolados e da Subclasse Residencial Baixa Renda cujo consumo seja igual ou inferior a $80 \mathrm{kWh} / \mathrm{mês."}$ 
À exceção das firmas de maior porte, que têm condições econômicas de contratar profissionais bem qualificados ou serviços técnicos especializados de consultoria, a grande massa dos agentes de mercado tem notados problemas relativos à aquisição do conhecimento e ao seu emprego no incremento da eficiência produtiva. Isso afeta não só o desempenho cotidiano das empresas, mas também se mostra um grande empecilho à realização de investimentos tendo em vista o aumento da produção ou a diversificação de mercados. Em alguns casos, a concessão de crédito desvinculada de assistência gerencial pode ser até mesmo prejudicial à empresa incentivada, pois cria uma dívida que não produzirá os resultados esperados. A deficiência no manejo das informações capazes de influenciar o desempenho da atividade econômica, não raramente, manifesta-se no puro desconhecimento que as empresas têm dos programas de fomento. Por isso é que parte das políticas de incentivo envolve a simples divulgação das iniciativas governamentais.

Sem pretender esgotar o tema, podem-se destacar os seguintes mecanismos:

(i) Assistência técnica, assistência de gestão e treinamento: trata-se, em suma, de qualificar os recursos humanos das empresas, proporcionando acesso ao conhecimento necessário à otimização da atividade produtiva, seja em relação a aspectos da tecnologia dos processos produtivos, seja no que toca a aspectos puramente gerenciais ${ }^{188}$. Envolve, portanto, a formação de mão-de-obra trabalhadora e capacitação empresarial. Nessa área atuam tanto as entidades que têm na capacitação de mão-de-obra seu escopo principal (SENAI, SENAC, SENAR), quanto entidades outras em que essa missão é menos relevante (EMBRAPA, cujo objeto principal é a pesquisa agrícola). Associações de classe também podem desempenhar tal papel, provendo uma utilidade de interesse comum das filiadas.

Em relação à formação de mão-de-obra, as políticas de incentivo podem incluir o fornecimento de treinamento, de cursos técnicos e mesmo de ensino superior afinado com as vocações econômicas regionais. Obviamente que qualquer boa política educacional de alcance nacional é fator predominante para o desenvolvimento produtivo. Mas no caso brasileiro, as dimensões do nosso território e a hetorogeneidade da atividade econômica nele espraiada exigem um juízo de ponderação a respeito do provimento de determinados

\footnotetext{
${ }^{188}$ A título de exemplo, a Lei 12.188/09 define como "Assistência Técnica e Extensão Rural - ATER: serviço de educação não formal, de caráter continuado, no meio rural, que promove processos de gestão, produção, beneficiamento e comercialização das atividades e dos serviços agropecuários e não agropecuários, inclusive das atividades agroextrativistas, florestais e artesanais".
} 
serviços educacionais ${ }^{189}$. Exemplo de reunião de instituições voltadas à qualificação profissional pode ser colhido no APL de cerâmica da região de Criciúma, onde a formação técnica é apontada como uma das vantagens competitivas que as empresas da região possuem $^{190}$.

Especificamente em relação à assistência de gestão e capacitação empresarial, vale citar os programas desenvolvidos pelo SEBRAE (que tem nessa atividade sua missão institucional), os quais podem ser entendidos, em último caso, como um treinamento, mas voltado não ao trabalhador, mas ao empresário. Nos últimos anos, tem sido frequente a oferta de cursos e seminários destinados à capacitação de empresas para a exportação. A FINEP, tal como várias agências estaduais de inovação, promove processos de capacitação empresarial mediante a apresentação de empreendedores fomentados por seus programas de financiamento e/ou subvenção a investidores de capital de risco; a insituição seleciona as firmas e as ajuda na formatação de propostas para que sejam apresentadas a investidores.

$\mathrm{Na}$ mesma linha de atuação podem ser entendidas as empresas incubadoras, entidades (na maioria das situações, vinculadas a universidades ou instituições de fomento

\footnotetext{
189 Nesse sentido, vale mencionar que a Lei n. ${ }^{\circ}$ 11.892/09, que Institui a Rede Federal de Educação Profissional, Científica e Tecnológica e cria os Institutos Federais de Educação, Ciência e Tecnologia, estabelece que estes têm dentre suas finalidades e características, "desenvolver a educação profissional $e$ tecnológica como processo educativo e investigativo de geração e adaptação de soluções técnicas $e$ tecnológicas às demandas sociais e peculiaridades regionais"(art. $\left.6^{\circ}, \mathrm{II}\right)$.

${ }^{190}$. Durante a décade de 2000, as empresas do APL de Criciúma, diante da perda de participação do mercado inteno (a região chegou a responder por mais de $20 \%$ da produção nacional de cerâmicas em 1995, mas em 2006 respondia por pouco mais de 11\%) para firmas paulistas e estrangeiras, voltadas a produtos de baixo custo, passaram a concentrar seus esforços em produtos de maior qualidade e design diferenciado; resultado dessa reorientação foi um crescimento significativo da exportação (quase 50\% de 2000 a 2006). Para que essa reorientação mercadológica fosse possível, entende-se que foi fundamental a existência de uma rede de qualificação de mão de obra. As principais instituições de ensino que servem ao APL são o Instituto Maximiliano Gaidzinski (oferece curso técnico em cerâmica e promove a Feira de Tecnologia Cerâmica FETEC, na qual ocorre a difusão de trabalhos e pesquisas na área cerâmica); Sociedade de Assistência aos trabalhadores do Carvão e o Centro Interescolar, que possuem papel relevante na criação de mão-de-obra qualificada para o APL, principalmente na área de química; Universidade do Extremo Sul Catarinense (instituição de ensino superior que conta com curso de Tecnologia em Cerâmica e Engenharia de Materiais cujos objetivos e conteúdos foram sugeridos pelo sindicato local dos ceramistas, Universidade Federal de Santa Catarina e pela Federação das Industrias do Estado); o Centro de Tecnologia em Cerâmica e Materiais do Senai (oferece serviços de testes e certificação e condução de projetos de pesquisa e desenvolvimento em conjunto com as empresas, possuindo laboratórios em várias áreas, dentre os quais de credenciamento de produtos; além disso, presta serviços tecnológicos em testes e ensaios de matérias-primas e produtos, e certificação de qualidade); e a UFSC, que disponibiliza professores, técnicos, alunos de graduação e pósgraduação para trabalhos de pesquisa nos laboratórios desse Centro. PINTO JR,Cyro C. G., FERNANDES, Ricardo L. e CAIRO, Silvio Antonio F. "Análise do Arranjo Produtivo Cerâmico de Revestimento da Região Sul de Santa Catarina: Dinâmicas Produtiva, Inovativa, Comercial e Institucional” Disponível em http://www.apec.unesc.net/II\%20EEC/Industrial/Artigo1.pdf.
} 
à pesquisa) que se destinam a preparar pequenas empresas recém criadas ${ }^{191}$. Esse trabalho de capacitação é especialmente relevante para a consolidação de empresas formadas por empreendedores dotados do domínio de algum aspecto do processo produtivo (muitas vezes, profissionais da área científica detentores de patente de relevante potencial de exploração econômca) mas desprovidos de expertise sobre aspectos gerencias da atividade empresarial e/ou do capital necessário à instalação física da empresa. As incubadoras fornecem estrutura física (salas, laboratório), serviços básicos (telefonia, secretariado, segurança), assessoria (jurídica, contábil, de gestão comercial e financeira) e até mesmo networking, fazendo com que as empresas incubadas possam travar contato com potenciais compradores.

(ii) certificação: cuida-se de atestar a observância de determinados padrões de qualidade adotados por uma firma em seu processo produtivo. A anuência a alguns padrões chega a ser requisito essencial à boa aceitação dos produtos em determinados mercados. Os mecanismos de certificação origiram-se de estratégias de políticas industriais de países europeus interessados em atestar ao mercado internacional a qualidade dos produtos nacionais, bem como destacar determinadas singularidades decorrentes do processo produtivo ou da região de procedência ${ }^{192}$. Essa política envolve, pois, a criação de padrões (normas técnicas), a inspeção de seu cumprimento pelas empresas, e mesmo o escrutínio das entidades responsáveis pela inspeção (acreditação ${ }^{193}$ ). Vale dizer que uma mesma atividade pode se submeter a diversos padrões de qualidade, desde os mais elementares, estabelecidos pelo sistema de metrologia legal, cuja observância pode ser obrigatória, até mesmo os que visem distinguir um produto ou serviço em razão de uma característica singular.

\footnotetext{
191 “As incubadoras, conforme Hackett e Dilts (2004) são espaços compartilhados que proporcionam às novas empresas recursos tecnológicos e organizacionais; sistemas que criam valor agregado; monitoramento e ajuda empresarial, com o objetivo de facilitar o sucesso dos novos empreendimentos, reduzindo ou eliminando o custo de potenciais falhas que se apresentam na criação do negócio e que são controladas no período de incubação. Com os novos empreendimentos recebem apoio do Governo, comunidades locais e investidores privados, com o intuito de superar determinadas dificuldades iniciais, tendo uma perspectiva de sucesso". RAUPP, Fabiano Maury \& BEUREN, Ilse Maria. "Programas oferecidos pelas incubadoras brasileiras às empresas incubadas". Revista de Administração e Inovação, São Paulo, v. 6, n. 1, 2009, p. 85.

${ }^{192}$ BRABET, Catherine \& PALLET, Domenique. "Os selos oficiais de qualidade dos alimentos na França e na Europa" em Valorização de produtos com diferencial de qualidade e identidade: indicações geográficas e certificações para competitividade nos negócios. Brasília: SEBRAE, 2005. pp. 19-41.

${ }^{193}$ Acreditação é o reconhecimento formal de que um organismo certificador (laboratório, organismo de certificação ou inspeção), atende a requisitos previamente definidos e demonstra ser competente para realizar suas atividades com confiança.
} 
No âmbito dos Arranjos Produtivos Locais, a certificação tem especial importância porque pode servir como um diferencial de um determinado produto em razão das características vinculadas à territorialidade, o que confere uma singularidade capaz de representar ganho de competitividade. Daí a importância das indicações geográficas, as quais, segundo a Lei n. ${ }^{\circ}$ 9.279/96, podem ser de duas espécies: indicação de procedência e denominação de origem (art. 176). Indicação de procedência é o "nome geográfico de país, cidade, região ou localidade de seu território, que se tenha tornado conhecido como centro de extração, produção ou fabricação de determinado produto ou de prestação de determinado serviço" (art. 177); já a denominação de origem é "o nome geográfico de país, cidade, região ou localidade de seu território, que designe produto ou serviço cujas qualidades ou características se devam exclusiva ou essencialmente ao meio geográfico, incluídos fatores naturais e humanos". Portanto, se há a possibilidade de se estabelecer uma identidade entre um produto e o território em que se dá a sua produção, deve-se explorar essa singularidade como uma vantagem competitiva ${ }^{194}$. O art. 182 da Lei n. ${ }^{\circ}$ 9.279/96 estabelece que "o uso da indicação geográfica é restrito aos produtores $e$ prestadores de serviço estabelecidos no local, exigindo-se, ainda, em relação às denominações de origem, o atendimento de requisitos de qualidade", ou seja, a certificação é um aspecto fundamental ao emprego do mecanismo da denominação de origem. Todavia, o Instituto Nacional de Propriedade Industrial não tem registradas muitas Indicações Geográficas nacionais (o que pode ser um indício de subaproveitamento desse instrumento por parte das instituições responsáveis peo desenvolvimento local), sendo que todos os registros realizados são na modalidade de Indicação de Procedência (o que denota a dificuldade de se identificar nos produtos regionais características denotadoras de qualidade singular e, portanto, maior valor agregado) ${ }^{195}$.

194 “O Brasil possui potencial para utilizar os dois instrumentos de Indicações Geográficas. Conforme a
configuração, podemos ter arranjos produtivos locais (APLs) com caracaterísticas diferenciadas. No caso
da Indicação de Procedência, esta apresenta caráter de manufatura e de serviço especializado que, por
conta do seu diferencial e concentração em determinados local, ganha fama que atravessa as fronteiras
enquanto referencia de excelência do território onde está instalada. Denominação de Origem associa-se às
características e peculiaridades físicas e humanas existentes no local. No primeiro caso podemos ter um
cluster que se vincula a uma determinada capacidade de empreendimento que surge no local, no segundo, a
uma vocação potencializada pelas condições territoriais. Os exemplos visíveis são parques tecnológicos e de
serviços especializados para os casos de indicação de procedência e produtos com características regionais
relacionadas a condições edafoclimáticas e peculiaridades locais, como exemplo de denominação de
origem”. GURGEL, Viviane A. "Aspectos Jurídicos da Indicação Geográfica em Valorização de Produtos
com Diferencial de Qualidade e Identidade” em Indicaçoses Geográficas e Certificações para
Competitividade nos Negócios. Brasília: Sebrae, 2005, pp. 56.
195 Segundo base do INPI atualizada até 09 de setembro de 2009, as seguintes Indicações Geográficas foram
registradas, todas elas na modalidade Indicação de Procedência: Café da Região do Cerrado Mineiro; Vinho 
Nos APLs de fruticultura, a certificação tem sido cada vez mais utilizada, eis que a cadeia de comércio global, principalmente nos países desenvolvidos, tem sido cada vez mais exigente em matéria de qualidade de produto e obdiência a padrões de produção. $\mathrm{O}$ Ministério da Agricultura e o INMETRO, a exemplo do que ocorre em vários outros países, elaboraram o marco normativo da Produção Integrada de Frutas, destinados à atestação da produção sustentável ${ }^{196}$. Apesar de se tratar de um sistema de adesão espontânea, tem tido crescente aderência por parte dos produtores em razão das pressões do mercado internacional.

Também vale mencionar as iniciativas adotadas pelos Estados da Federação no sentido de dar destaque a produtos passíveis de diferenciação em razão de sua localização. Rio de Janeiro, Santa Catarina e Rio Grande do Sul e Espírito Santo criaram selos identificadores de qualidade designativos de determinadas regiões ${ }^{197}$. Ainda que essas "marcas" não contem com a proteção do registro do Intituto Nacional de Propriedade Industrial, podendo operar efeitos apenas no âmbito estadual, elas podem ter alguma consequência mercadológica, principalmente caso verificada a atuação persistente do poder público com o fito de consagrar a certificação

(iii) Inteligência de mercado: nesta categoria incluem-se diversas medidas relativas à estratégia de inserção ou expansão de uma firma ou conjunto de firmas num determinado mercado. Podem-se citar ações de promoção comercial (marketing de marcas regionais mediante a veiculação em mídia), realização de feiras de negócios nacionais e internacionais, instalação de centros de negócios no exterior e realização de pesquisas de mercado.

$\mathrm{Na}$ promoção de exportações, a assistência comercial se mostra especialmente relevante. Trata-se de auxiliar a inserção da produção nacional em mercados consumidores estrangeiros. Esse tipo de ação se faz importante porque, afora a diminuta lista de produtos que dominam a pauta de exportação nacional em razão de vantagens competitivas

tinto, branco e espumantes do Vale dos Vinhedos; Carne Bovina e seus derivados do Pampa Gaúcho da Campanha Meridional; Aguardentes, tipo cachaça e aguardente composta azulada de Paraty; Uvas de Mesa e Manga do Vale do Submédio São Francisco; Couro Acabado do Vale do Sinos. Fonte: sítio do INPI na internet: www.inpi.gov.br. Acessado em 02.01.2010.

196 Instrução Normativa $\mathrm{n}^{\text {o }}$ 20, de 27 de Setembro de 2001, do Ministério da Agricultura - Aprova as Diretrizes Gerais para a Produção Integrada de Frutas - DGPIF e as Normas Técnicas Gerais para a Produção Integrada de Frutas - NTGPIF.

${ }^{197}$ MACHADO, Alexandre F. “As Indicações Geográficas no Brasil e no Mundo - panorama atual”. Em BALIEIRO LIMA, Luis F. (org.). Propriedade Intelectual no Direito Empresarial. São Paulo: Quartier Latin, 2009, pp 178-180. 
pronunciadas que os fazem notórios por todo o globo, há milhares de outros mercados em que vigora uma enorme assimetria de informações (senão mesmo puro e simples desconhecimento) entre produtores de um país e consumidores de outros. Assim é que essa espécie de promoção de exportações faz identificar e revelar as potencialidades dos produtos nacionais face aos seus concorrentes (efetivos e potenciais) de outro país.

Uma instituição que tem destacada atuação nesse ramo é a Agência Brasileira de Promoção das Exportações e Investimentos - APEX. Essa entidade, de 1997 até 2003, figurava como um órgão do Sebrae Nacional, contudo, com a edição da Lei n. ${ }^{\circ}$ 10.688/04, passou a ter personalidade jurídica própria, revestindo-se da forma de "serviço social", pessoa jurídica de direito privado sem fins lucrativo, mas vinculada ao MDIC. Em linhas gerais, a APEX tem como propósito estabelecido em Lei "promover a execução de políticas de promoção de exportações, em cooperação com o Poder Público, especialmente as que favoreçam as empresas de pequeno porte e a geração de empregos". Isso se traduz em diversos projetos e ações destinados não só ao quanto estabelecido em Lei, mas, de um modo geral, a inserir produtos e empresas brasileiras no mercado externo $^{198:}$ Em termos concretos, a APEX tem realizado projetos destinados a beneficiar empresas de determinado setor, propostos por entidades de classe ou pela própria Agência, mediante a realização de ações de promoção (feiras, eventos, encontros comerciais), prospecção de mercados, mapeamento de oportunidades de negócio, bem como a instalação de centros de negócios no exterior (escritórios de apoio destinados a prover infra-estrutura física às empresas para atividades temporárias). A Agência não promove empresas individuais, exigindo que elas se apresentem em conjunto, por intermédio de uma entidade de classe, daí que sua principal linha de atuação se dá pelos Projetos Setoriais Integrados $^{199}$, nos quais a APEX pode subvencionar o custo de até $50 \%$ das ações de promoção comercial acima referidas ${ }^{200}$.

198 De acordo com os documentos que compõem o planejamento da entidade, a missão institucional da APEX
consubstancia-se nas seguintes tarefas: identificar vocações produtivas regionais; fortalecer as entidades de
classe; realizar estudos e prospecções de mercado; firmar acordos de cooperação com redes internacionais;
realizar grandes eventos, tendo o Brasil como tema; inserir novas empresas no mercado internacional;
promover encontros de negócios com importadores; executar/coordenar eventos internacionais (missões
comerciais, feiras, encontros de negócios); promover a imagem do Brasil
${ }^{199}$ Em dezembro de 2009 , o sítio da APEX na internet dava conta da existência de 19 PSI em andamento,
destinados a promover os seguintes produtos brasileiros no exterior: carne bovina; biscoitos; material
genético e outros produtos relacionados ao gado zebu; frangos; frutas e derivados; genética das raças braford
e hereford; inserção competitiva das empresas brasileiras de micro, pequeno e médio portes do setor sisaleiro;
grãos especiais de café; carne suína; construção do mercado mundial de etanol de cana de açúcar; divulgação
dos produtos típicos e tradicionais brasileiros (alimentos e bebidas) - 'ethnic brazil"; promoção comercial de
mel e derivados; erva mate; produtos orgânicos; indústria de alimentos, acessórios, vacinas e outros produtos 
No âmbito do MDIC, é de se citar o Sistema Radar-Comercial, tutelado pela Secretaria de Comércio Exterior, propicia aos usuários cadastrados informações diversas sobre inúmeros produtos (preço médio, potencial importador, dinamismo, performance da exportação brasileira, valores exportados e importados, principais países concorrentes, medidas tarifárias, medidas não tarifárias) de mais de 60 países, representativos de $90 \%$ do comércio mundial. Como medida de promoção das firmas brasileiras com potencial exportador, o MDIC desenvolve o programa Vitrine do Exportador, cujo propósito principal é dar maior visibilidade às empresas, oportunizando a eventuais importadores entrangeiros o acesso a informações das empresas nacionais.

$\mathrm{O}$ instrumento de incentivo tratado neste tópico é talvez o que tem maior aplicabilidade no âmbito dos APLs. Primeiramente, porque a maioria das empresas que compõem os Arranjos é de pequeno e médio porte e por isso apresentam grande carência em relação às utilidades aqui citadas. Em segundo lugar, cabe ressaltar que os aspectos aptos a conferir vantagem competitiva ao conjunto de empresas de um Arranjo exigem a articulação de ações coletivas de cuja iniciativa nem sempre os particulares se encarregam. Medidas como a criação de uma marca coletiva, a promoção de feiras e eventos no exterior, a acreditação de laboratórios e entidades aptos a realizar a certificação, ou, ainda, a disseminação de novos métodos produtivos por meio de oferecimento de capacitação e assistência técnica são papéis que, se o Estado se furtar a exercer, podem redundar em grande prejuízo ao desevolvimento produtivo.

veterinários para animais de companhia; equipamentos, produtos e serviços das empresas do setor sucroalcooleiro, assim como a projeção do país como referência mundial na produção de equipamentos e provedor de serviços para a produção de energias renováveis; chocolates, cacau, amendoim, balas e derivados em mercados não conhecidos (sudeste asiático e oceania) ou mesmo via mercados ainda pouco explorados pelas empresas (oriente médio, leste europeu, ásia ocidental); vinhos finos. A grande maioria incluía a realização ou participação de feiras internacionais, ações de marketing e treinamento das firmas nacionais para a atividade exportdora.

${ }^{200}$ Ver Manual de Convênios, APEX-Brasil: “4. Do Apoio Financeiro ao Projeto e das Contrapartidas. 4.1. $O$ montante aportado pela Apex-Brasil será definido de acordo com a avaliação técnica procedida pela Agência. 4.1.1. Em se tratando de PSI, o montante aportado pela Apex-Brasil será de até 50\% (cinqüenta por cento) do valor do projeto, de acordo com o interesse da Agência. 4.1.2. Quando a Agência detectar a presença de elementos críticos para a consecução dos objetivos do projeto, ou quando o objeto do projeto, a critério da Apex-Brasil, seja de relevante interesse para as políticas nacionais de comércio exterior, a participação da Agência poderá ser superior ao limite estabelecido no item 4.1.1.; 4.2. O apoio financeiro da Apex-Brasil condiciona-se ao aporte de contrapartida pelo Proponente, pelas empresas beneficiárias do projeto elou pelos demais partícipes, e poderá ser de recursos financeiros, bens ou serviços, desde que economicamente mensuráveis. 4.2.1. Nos casos dos PSI, o total de recursos de contrapartida deverá ser composto por, no mínimo, $50 \%$ (cinqüenta por cento) de recursos financeiros, e até 50\% (cinqüenta por cento) de recursos econômicos". 


\subsection{CONCLUSÃO PARCIAL}

Este capítulo intentou demonstrar o poder regulatório do fomento público. O conteúdo normativo do incentivo estatal tem a peculiaridade de guiar a ação privada através de estímulos representativos de vantagens ao exercício de determinadas atividades. E foi visto que são diversos os mecanismos à disposição do Estado para que este busque o desenvolvimento produtivo.

Trazendo-se aqui as observações do cap. 1, vê-se que os instrumentos do fomento, abstratamente considerados, podem compor um quadro de medidas que se afeiçoa às políticas horizontalizadas (no sentido de que, em princípio, aplicam-se a praticamente todos os setores da economia, independentemente da região geográfica). Nessa perspectiva, é possível cogitar da aplicabilidade genérica das medidas de fomento em prol do desenvolvimento de determinadas localidades, quaisquer que sejam elas.

Todavia, o emprego correto dos institutos aqui mencionados em favor dos APLs implica, forçosamente, que a atividade de fomento se caracterize como uma intervenção seletiva do Estado na economia. Isto porque, em sendo cada APL uma realidade específica, não há como se pretender aplicar em bloco todas as formas possíveis de fomento possíveis. Essa impossibilidade (considerando-se um dever de otimização do gasto público que impeça o desperdício) se acentua pelo fato de que a forma pelo qual os agentes se articulam para se engajarem em ações coletivas pode variar muito de caso para caso. Isto é, as políticas de fomento dos APLs têm de observar que há uma dimensão cooperativa no funcionamento dos agentes - e é justamente em torno dessa ideia que se estrutura o cap. 3, o qual tenta dar conta de alguns traços peculiares do fomento dos Arranjos. 


\section{CAPÍTULO 3 \\ POLÍTICAS ESPECÍFICAS DE PROMOÇÃO DOS APLS}

Não obstante as habituais dificuldades presentes na formulação de políticas públicas em países subdesenvolvidos, principalmente a falta de recursos, uma política industrial que vise ao fomento dos APLs não pode ignorar a absoluta especificidade que caracteriza cada aglomeração. As situações em que se reconhece a importância de articular e coordenar os agentes econômicos vinculados à determinada atividade são várias e cheias de nuances próprias. Cada APL corresponde a uma situação fática marcada pelas peculiaridades locais e dos mercados envolvidos no processo produtivo. Podemos nos deparar tanto com um arranjo extrativista nos rincões do país, onde o desafio é superar arcaísmos dos métodos de produção e adensar o valor do produto, quanto com um programa de incentivo à exportação de serviços de alta tecnologia prestados por pequenas empresas de tecnologia da informação. Por isso é muito difícil estabelecer prescrições de políticas públicas que sejam amplamente aplicáveis a todo e qualquer Arranjo ${ }^{201}$. A dificuldade, todavia, não advém somente das peculiaridades fáticas em que o APL se insira. A estruturação das políticas de fomento também se mostra dificultosa pela própria natureza multifacetada da intervenção estatal. Nesse sentido, esclarece Fabio Stefano ERBER:

As características que singularizam os APLs - coletivos multiinstitucionais determinados geográfica e setorialmente colocam também um problema de ação conjunta para as próprias políticas públicas. Para serem eficazes, tais políticas têm de harmonizar instrumentos de vários tipos de fomento (setorial, territorial, de PME), cuja governança está sujeita a diversas instituições públicas, tanto no plano funcional como territorial. Tal harmonização requer mecanismos de elaboração, implementação e monitoramento não triviais, especialmente em países de grande

\footnotetext{
${ }^{201}$ Anderson Tadeu MARQUES CAVALCANTE assinala que: "[n]ão existe uma política única, inflexível, que sirva aos propósitos de qualquer aglomeração produtiva e que possa ser aplicada em qualquer lugar do mundo. Essa idéia parece permear o pensamento de alguns governos e estudiosos e é, no mínimo, inocente; cada aglomeração produtiva possui seus atributos, seus agentes, inserção própria no ambiente, tipo e escala de produção, tipo de inovação presente (ou não) etc". Financiamento e Desenvolvimento Local: um estudo sobre Arranjos Produtivos Locais. Doutorado em Economia. UFMG, 2006.
} 
extensão e diversidade territorial e onde os aparatos estatais são precários, como no caso brasileiro ${ }^{202}$.

Como se isso não bastasse, não é de se ignorar que principalmente sob o enfoque das entidades federais, as políticas destinadas às aglomerações locais tenham de estar minimamente consoantes à uma estratégia nacional de desenvolvimento industrial, sem o que talvez a própria presença da União não se justifique. Essa preocupação com a integração dos Arranjos aos centros dinâmicos é um dos principais vetores da política de redução das disparidades regionais.

A dificuldade que se verifica, pois, é: se é próprio de uma política de Estado algum grau de homogeneidade de atuação em face da realidade sobre a qual se intervém, como garantir que realidades tão particulares como os APLs possam ser tuteladas por entidades públicas de maneira apropriada? Talvez haja como ponderar os imperativos de generalidade e universalidade das políticas públicas e a necessidade de atendimento específico das diferentes realidades econômicas locais. Isso pode ser feito estabelecendo-se alguma tipologia dos APLs que revele caracteres suficientes para identificar determinadas classes de aglomerações e direcionar-lhes medidas comuns de incentivo.

\subsection{TiPologias de CARACTERIZAÇÃo dos APLS E CONSEQUÊNCIAS PARA PROMOÇÃo DE POLÍTICAS PÚBLICAS}

Para além da análise dos instrumentos de promoção pertinentes em razão dos aspectos definidores do próprio conceito de APL, pode-se detalhar um pouco mais as estratégias de atuação fomentadora estatal em razão de características de determinados arranjos. Isto é, assume-se que o simples fato de se tratar de um APL não explica o suficiente sobre a realidade local. Daí a razão de se adotar uma tipologia.

Assim é que se pretende expor, primeiramente, as tipologias de identificação e caracterização de APLs empregadas em alguns documentos oficiais e verificar o que se está levando em consideração ao se selecionar uma determinada configuração produtiva

202 "Eficiência coletiva em arranjos produtivos locais industriais: comentando o conceito". Nova Economia. Belo Horizonte: UFMG, n. ${ }^{\circ}$ 18, jan./abr. 2008, p. 28. 
como objeto de política pública ${ }^{203}$. O GTP-APL foi encarregado da elaboração de um termo de referência para identificação das aglomerações ${ }^{204}$. Contudo, o primeiro levantamento de APLs realizado por todos os componentes do GTP-APL foi realizado com base nos critérios e experiência próprios de cada entidade. Somente com a elaboração do Relatório do IPEA sobre Identificação, Mapeamento e Caracterização Estrutural de APLs no Brasil é que se pode afirmar existir um referencial minimamente sólido para o estabelecimento da atuação do poder público; todavia, não há indícios de que esta proposta tenha sido albergada pelas entidades governamentais até o momento.

De todo modo, pode-se ter como referencial analítico uma tipologia concernente ao papel que os APLs desempenham na economia e as consequências de políticas que disso advêm. Nesse sentido, SUZIGAN, FURTADO, GARCIA \& SAMPAIO oferecem um modelo $^{205}$. Segundo esses autores, as aglomerações poderiam ser agrupadas em quatro categorias:

(i) núcleos de desenvolvimento setorial-regional: SLP que se destacam duplamente: pela grande importância para uma região e para o setor de atividade econômica ao redor da qual sua atividade se vincula (ex: Franca/calçados, Limeira/jóias, Ribeirão Preto/equipamentos médicos).

(ii) vetores avançados: SLP de grande importância para o setor e pequena importância para o desenvolvimento econômico regional (ex: São Paulo/material

\footnotetext{
${ }^{203}$ Como bem apontam Eduardo NORONHA e Lenita TURCHI: "A discussão sobre a definição de APLs ganhou importância sob vários pontos de vista. A sinalização governamental de criação de políticas de apoio para APLs gerou esforços de diversos municípios, regiões e estados da Federação no sentido e de que seus aglomerados produtivos fossem classificados como APLs. Na interpretação de técnicos e políticos, a "marca APL" tornou-se necessária para o possível acesso a políticas públicas. Do ponto de vista acadêmico, o debate conceitual deriva da boa prática da busca de homogeneização da linguagem. Aliás, mais que isso, trata-se da identificação do próprio objeto de estudo, isto é, da necessidade de saber-se se os diversos pesquisadores estão se referindo a objetos empíricos similares ou se estão chamando de APL aglomerados produtivos com características demasiadamente díspares para receberem o mesmo tratamento analítico". "Política Industrial e Ambiente Institucional na Análise de Arranjos Produtivos Locais". IPEA. Texto para Discussão n. ${ }^{\circ}$ 1076. Brasília, 2005, p. 09.

204 Esse sintético Termo de Referência para Política Nacional de Apoio ao Desenvolvimento de Arranjos Produtivos Locais (Brasil, 2004) indica que a identificação de um APL se faz a partir do reconhecimento das seguintes variáveis: a concentração setorial de empreendimentos no território; concentração de indivíduos ocupados em atividades produtivas relacionadas com o setor de referência do APL; cooperação entre os atores participantes do arranjo (empreendedores e demais participantes) em busca de maior competitividade e existência de mecanismos de governança.

205 . "Sistemas Locais de Produção: Mapeamento, Tipologia e Sugestões de Políticas". Revista de Economia Política, v. 24, n. 4, p. 543-562, 2004. Os autores se valem da noção de "sistema locais produtivos" (SLP), cuja definição não contrasta com o conceito de APL utilizado nesta dissertação.
} 
eletrônico; Campinas/telecomunicações e equipamentos óticos; São Paulo/vestuário)

(iii) vetores de desenvolvimento local: SLP de grande importância regional, mas de pequena importância para o setor (Campos do Jordão/confecções; Dracena Cerâmica, Amparo/confecções)

(iv) embrião de arranjo produtivo: SLP de pouca importância setorial e regional (Mogi-Mirim/cerâmica; Ribeirão Preto/máquinas agrícolas, Limeira/máquinas e ferramentas);

Para cada classe de SLP haveria uma orientação primordial de política de fomento:

(i) Para os núcleos de desenvolvimento regional-setorial, incremento das capacidades técnicas e das forças comerciais autônomas como medida de alcance de um patamar superior de desenvolvimento e competitividade. Parte-se do pressuposto de que a função industrial-produtiva estaria superdimensionada em relação a aspectos ancilares de formação da reputação dos produtos junto aos grandes mercados;

(ii) Para os vetores avançados, não se recomenda que a política industrial the dispense um tratamento vinculado ao desenvolvimento regional, dada sua importância diminuta em relação ao entorno, normalmente de estrutura produtiva evoluída e diversificada. Entende-se que, de uma maneira geral, não há mecanismos que assegurem o estabelecimento de vínculos fortes entre os vetores e o conjunto de atividades que o cerca, dado o pequeno grau de dependência;

(iii) Os vetores de desenvolvimento local seriam os mais aptos a receber medidas de incentivo. Prevê-se um processo de aplicação de medidas de fomento mais eficaz e menos sujeito a riscos, dado que já se superou o estado embrionário da atividade produtiva ao mesmo tempo que se tem uma estrutura minimamente estabelecida, de forma a permitir as devidas adaptações e correções de rumo no processo de desenvolvimento da estrutura de produção.

(iv) Para os embriões de sistema local de produção, categoria que congrega o maior número de SLP, recomenda-se que as medidas de incentivo sejam apresentadas e disponibilizadas em etapas sequenciais e condicionadas a contrapartidas por parte dos beneficiários a fim de que a expansão das atividades se dê de forma consistente, por meio da conquista gradual de nichos de mercado a serem identificados. 
Como medida aplicável a todos os setores, os autores recomendam que a política industrial não seja interventiva de tal modo a substituir a ação dos protagonistas locais (empresas, empresários, trabalhadores e entidades associativas). Ademais, independentemente do sistema, deve-se proporcionar (i) condições para o fortalecimento dos mecanismos de cooperação entre os agentes como medida de criação de eficiência coletiva, (ii) criação de espaços e instituições de alcance geral, com gestão compartilhada dos recursos (preferencialmente dos próprios partícipes, ou, ao menos, em proporção cada vez maior em relação ao montante de investimento público).

José E. CASSIOLATO \& Helena M LASTRES sugerem como diretriz geral para políticas de incentivo a busca do aprofundamento das complementaridades produtivas locais, diversificando especializações de forma que as firmas "individualmente $e$ coletivamente possam avançar em direção a produção de produtos com maior complexidade tecnológica estabelecendo um circulo virtuoso de relações econômicas $e$ tecnológicas". O campo propício para tal forma de atuação seriam espaços em que existam empresas minimamente aptas ao desempenho das especializações locais; em havendo essa condição inicial, pode-se-definir as políticas verticais e regionais cabíveis ${ }^{206}$.

Já sob a perspectiva das políticas de fomento financeiro, Marco A. VARGAS, José E. CASSIOLATO \& J. P. BRITTO propõe uma diferenciação das políticas da seguinte maneira $^{207}$ :

Para os Arranjos não estruturados de Micro e Pequenas empresas, recomenda-se a desoneração fiscal de algumas atividades, a redução de taxas de juros; a constituição de fundos de aval e fornecimento de contra-garantias intermediadas por instituições de fomento, vinculação de garantias a compromissos coletivos em termos da melhoria de performance; sistemas de garantias para microfinanças, subvenções. O apoio a programas de capital de risco adviria de incentivos fiscais para fundos/investidores privados; garantias para investidores em fundos de criação de arranjos de MPMEs; recursos a fundo perdido, para reduzir os custos de transação na administração de fundos para arranjos incipientes; redução da carga fiscal e incentivos para investidores privados.

${ }^{206}$ CASSIOLATO, José E. \& LASTRES, Helena. M. "O foco em arranjos produtivos locais de micro e pequenas empresas" em: LASTRES, Helena M. M.; CASSIOLATO, José E.; MACIEL, M.L. Pequena Empresa: Cooperação e desenvolvimento local. Rio de Janeiro. Relume Dumará, 2003, p. 579.

${ }^{207}$ VARGAS, M. A.; CASSIOLATO, José E. ; BRITTO, J. P. . "Instrumentos Financeiros para Arranjos e Sistemas de MPME" apud MOTTA DE LIMA, Adelaide, CASTRO LIMA, Carmen Lucia \& RODRIGUES MATTA, João P. "Finanças de proximidade: um modelo de financiamento para arranjos produtivos locais". Disponível em www.neapl.sedetec.se.gov.br/modules/wfdownloads/visit.php?cid=1...3. 
Para arranjos consolidados ou em consolidação, o foco estaria na promoção de programas de capital de risco que se concretizariam em: fundos setoriais de capitais de risco com participação governamental para sistemas de micro, pequenas e médias empresas de elevado potencial de crescimento; redução de carga fiscal e incentivos para investidores privados; adaptação das normas relativas ao portfólio de aplicações de investidores institucionais; além da flexibilização nos critérios de enquadramento de empresas de capital aberto com a Comissão de Valores Mobiliários, visando facilitar o acesso das empresas ao financiamento via mercado finaceiro.

Já para os sistemas de MPMEs com potencial inovativo, as atenções das políticas públicas deveriam se voltar para programa de capacitação inovativa. Isso implica a concessão de bolsas para pesquisadores atuarem nas empresas, emprego de subvenção por instituições de apoio tecnológico articulados com os APLs, inclusive no desenvolvimento de projetos de pesquisa cooperativa para solução de gargalos tecnológicos dos arranjos; linhas especiais de crédito para financiamento de empresas em incubadoras tecnológicas; e formação de fundos de capital de risco para investimento em sistemas de MPMEs com elevado potencial inovativo.

Importante destacar aqui a predominância de dois aspectos: o acesso ao crédito e a geração de inovações no processo produtivo. A questão do financiamento, de fato, é praticamente onipresente, principalmente diante das sérias dificuldades de empresas de menor porte obterem financiamentos de maior monta.

Por essa exposição já se percebe que não é possível pressupor uma política absolutamente uniforme para os APLs; isso significaria talvez não promover política alguma. As tipologias já albergam a escolha de alguns padrões de aglomerações produtivas e não são, portanto, neutras, e revelam uma maior aplicabilidade a determinados casos, podendo, em outros, não dar conta de algumas peculiaridades. De todo modo, em matéria de política de promoção dos APLs, parece que, a despeito das configurações particulares de cada arranjo, incidem ao menos as questões relativas (i) à governança das ações cooperativas do arranjo; (ii) ao modo pelo qual as entidades governamentais podem atuar conjuntamente e (iii) aos instrumentos dos quais as firmas podem se valer para fruir dos mecanismos de fomento (possibilidade de aproveitamento por uma multiplicidade de agentes). É disso que se tratará nos próximos tópicos. 


\subsection{AS ESPECIFICIDADES DA PROMOÇÃO DOS APLS: FOMENTANDO AÇÕES COLETIVAS}

Uma questão prévia que se impõe às medidas de fomento de ações no âmbito de um APL é a delimitação dos seus beneficiários. Há de se identificar o universo de empresas que compõem o Arranjo, o que envolve uma definição das atividades que devem ser compreendidas no APL (apenas uma etapa ou, do contrário, duas ou mais etapas da cadeia produtiva que se realizem predominantemente numa dada região - caracterizando um arranjo horizontal ou vertical), bem como do âmbito geográfico pelo qual se espraiam as atividades eleitas para promoção. Não que o eventual dilargamento do universo de beneficiários seja por si só indevido, eis que as políticas de fomento não têm de ser necessariamente dotadas de grande foco; contudo, fato é que a delimitação mais rigorosa dos agentes beneficiados num APL permite aperfeiçoar a ação pública, eis que não se corre o risco de se dispersar recursos e esforços numa gama muito extensa de ações, as quais nem sempre contam com recursos em abundância para serem executadas.

\subsubsection{Arranjo, cooperação e governança}

Um APL congrega atores de diferentes naturezas e propósitos. Coexistem no arranjo empresas de diferentes portes, entidades de classe e as mais diversas entidades governamentais, desde representantes de Ministério e Secretarias de Estado, até bancos de desenvolvimento, agências de fomento, universidades e centros tecnológicos. Cada qual opera segundo o influxo de um regime jurídico próprio.

A forma pela qual todos esses agentes conjugam esforços é determinante do sucesso das políticas de fomento ao Arranjo. De fato, sem a existência de vínculos especiais entre os agentes econômicos envolvidos no processo produtivo, seja numa configuração horizontalizada ou verticalizada, não se pode sequer falar na existência de um APL, mas tão-somente de agentes em situação de concorrência ou de fornecimento/aquisição de insumos e produtos. Daí a importância que categorias de cooperação e capital social assumem na explicação das vantagens aglomerativas. Por capital social aqui se entende o conjunto de relações estabelecidas entre agentes que lhe permitem trabalhar em termos cooperativos, tendo em vista objetivos comuns; o conceito de capital social ainda não é objeto de consenso, até porque sua pretensão explicativa o faz ser aplicado a campos de estudo diversos, suscitando abordagens diferentes. A Pierre 
BOURDIEU, James COLEMAN e Robert PUTNAM se devem a criação e difusão do termo $^{208}$. Aglomeração produtiva não implica a existência de um arranjo; este só surge na presença de práticas cooperativas entre as firmas e entra estas e as instituições de apoio ${ }^{209}$. Mas ainda que práticas cooperativas sejam uma premissa do modelo de APL, isso não significa: (i) que inexistam espaços da decisão autônoma dos agentes ou que eles não estejam em ambiente de competição (principalmente quando empresas atuam no mesmo ramo), bem como (ii) que o capital social local não possa ser incrementado por ações deliberada; isto é, que os vínculos estabelecidos entre os agentes possam se estreitar e as ações de coordenação explícita otimizar a ação das empresas envolvidas ${ }^{210}$.

Paulo R. HADDAD chama atenção para o fato de que coexistem num APL três campos decisórios distintos: o das decisões privadas, pertinentes unicamente aos empresários; o das decisões governamentais, que diz respeito à oferta dos serviços disponibilizados pelo Estado, e o das decisões comunitárias, referentes a problemas comuns às empresas do arranjo cuja solução por um agente individual é impossível. Segundo o autor:

no campo das decisões comunitárias que se concentra um grande número de externalidades positivas que geram as principais

\footnotetext{
208 COSTA, Achyles B. da \& COSTA, Beatriz M. da. Cooperação e Capital Social em Arranjos Produtivos Locais. Disponível em http://www.anpec.org.br/encontro2005/artigos/A05A113.pdf. Esses autores citam a definição de BOURDIEU, que toma o capital social como "conjunto de recursos atuais ou potenciais que estão ligados à posse de uma rede durável de relações mais ou menos institucionalizadas de interconhecimento e de inter-reconhecimento ou, em outros termos, à vinculação a um grupo, como conjunto de agentes que não somente são dotados de propriedades comuns (passíveis de serem percebidas pelo observador, pelos outros ou por eles mesmos), mas também são unidos por ligações permanentes e úteis" (op. cit, p. 05). Vale destacar do trabalho mencionado, ainda, a seguinte passagem: "Bourdieu, Coleman e Putnam convergem ao afirmarem que o capital social representa um recurso ou ativo que, a exemplo do capital econômico, pode ser acumulado. Todavia, de modo diverso ao capital econômico, que tem um proprietário e cujos direitos são assegurados por lei, o capital social tem o caráter de bem público; somente pode ser acumulado mediante a manutenção e ampliação das relações sociais que ocorrem em nível da comunidade, a qual não tem nenhum reforço legal para reivindicar sua propriedade" - (op. cit, p. 07).

209 “Um aglomerado de empresas em si, como já mencionado, não leva necessariamente à cooperação. É necessária a existência de uma estrutura de relacionamentos entre os agentes envolvidos na produção local. Contudo, o relacionamento é uma condição necessária, mas não suficiente para que ocorra a cooperação. É preciso que elas estejam assentadas em um enraizamento (embeddedness) no local, onde os agentes compartilhem história, normas e valores comuns, facilitando o desenvolvimento de capital social e funcionando como um anteparo, um controle, a comportamentos oportunistas ou mal-intencionados" In COSTA, Achyles Barcelos da; COSTA, Beatriz Morem da . "Cooperação e Capital Social em Arranjos Produtivos Locais". In: XXXIII Encontro Nacional de Economia (ANPEC), Natal-RN, 2005. Disponível em www.anpec.org.br/encontro2005/artigos/A05A113.pdf

210 "Formações sociais são estruturas complexas, que resultam de construção social ao longo de processos históricos de colaboração, competição e conflito. E, nesses processos, desempenham também papel fundamental as políticas e estratégias, tanto públicas como privadas. A conclusão, portanto, é que a oposição 'induzido/espontâneo' discutida na literatura sobre capital social representa uma falsa dicotomia” In ALBAGLI, S. \& MACIEL, M. L. Capital social e desenvolvimento local. Pequena empresa - cooperação e desenvolvimento local. Rio de Janeiro: Relume Dumará, 2003.
} 
economias de aglomeração e que explicam a gênese de um APL. É óbvio que um APL tem reduzidas chances de se estruturar e de se consolidar, se não vier a se instalar entre as empresas que o compõem um ambiente de competição cooperativa, se não se eliminar o clima de desconfiança entre elas, se as empresas não abandonarem atitudes defensivas quando ocorrerem resultados adversos. A organização de um APL é um jogo de soma positiva, na medida em que permite às empresas resolverem problemas de interesse comum, com benefícios maiores ou menores para todas elas $^{211}$.

Na mesma linha, Fábio S. ERBER, ao tratar da eficiência coletiva em APLs, destaca que a participação do Estado no processo indutor da criação de cooperação deve se dar pela criação de instituições capazes de prestar serviços de interesse comum às firmas participantes. Veja-se:

Conforme já apontado, as características territoriais e setoriais dos APLs, o peso que neles têm as PMEs e a inexistência ou a precariedade de mecanismos de mercado que levem ao seu desenvolvimento, fornecem bons motivos para a intervenção do Estado para fomentar os APLs, seja por motivos de eficiência econômica (aumento de investimentos, criação de empregos, geração de divisas), seja por razões de eqüidade social, territorial e entre empresas. No entanto, a hipótese de unidade do APL faz com que as políticas destinadas a fomentá-los sejam distintas das políticas tradicionais de apoio às PMEs, a despeito do peso que estas possam ter dentro do arranjo. Revendo as políticas de apoio aos APLs à luz da análise precedente, pode-se interpretá-las como destinadas principalmente a gerar ativos de uso coletivo pelos participantes do arranjo, notadamente as PMEs. Tais ativos têm de estar organizados em instituições específicas, que se tornam fornecedoras de externalidades para os membros do APL, especialmente quando a "precificação" dos serviços prestados pelos ativos é problemática. Assim, recomenda-se freqüentemente a intervenção pública para a criação emanutenção de instituições como centros de pesquisa, de assistência técnica, de formação de empreendedores, de apoio à exportação etc., operando com preços $\operatorname{administrados}^{212}$.

Sem pretender adentrar em questões relacionadas à economia das empresas, podese dizer que, de um modo geral, quão mais nítida for a possibilidade de obtenção de ganhos sem comprometimento da posição de mercado por parte das firmas envolvidas, mais a ação cooperativa terá chances ocorrer. Daí que as possibilidades de protagonismo em ações de

\footnotetext{
211 HADDAD Paulo R. Texto de Referência da Palestra Sobre Cultura Local e Associativismo. Rio de Janeiro: BNDES, 2004.

212 "Eficiência coletiva em arranjos produtivos locais industriais: comentando o conceito". Nova Economia. Belo Horizonte: UFMG, n. ${ }^{\circ}$ 18, jan./abr. 2008, p. 25.
} 
articulação produtiva resultam de uma simples suposição de que as firmas tendem a agir diante da existência de uma oportunidade de auferição de algum proveito. Da mesma forma, a possibilidade de perda das vantagens competitivas ou a criação de custos cuja assunção seja de difícil determinação entre os agentes (propiciando os "caronistas" - free riders) tendem a dificultar a cooperação no APL. Nesse sentido, as políticas de promoção dos Arranjos podem observar uma progressão de ação baseada na implementação das medidas de aceitação mais fácil entre os agentes para buscar, depois, e se for o caso, aplicação dos esquemas de articulação que demandem uma disposição maior das firmas locais. No quadro a seguir, propõe-se uma tipologia que reflita as afinidades que cada agente de um Arranjo pode ter com algumas ações específicas de promoção. Em seguida, comentam-se os aspectos nele mencionados.

\begin{tabular}{|c|c|c|c|c|c|c|}
\hline \multicolumn{7}{|c|}{ Possibilidades de engajamento em ações de articulação produtiva ${ }^{213}$. } \\
\hline & $\begin{array}{c}\text { Empresas } \\
\text { em Arranjo } \\
\text { Horizontal }\end{array}$ & $\begin{array}{c}\text { Empresas } \\
\text { em Arranjo } \\
\text { Vertical }\end{array}$ & $\begin{array}{l}\text { Poder } \\
\text { Local }\end{array}$ & $\begin{array}{l}\text { Associação } \\
\text { de empresas }\end{array}$ & $\begin{array}{c}\text { Entidades de } \\
\text { apoio gerencial } \\
\text { e assistência } \\
\text { comercial }\end{array}$ & $\begin{array}{c}\text { Centros de } \\
\text { pesquisa }\end{array}$ \\
\hline $\begin{array}{c}\text { (i) Capacitação de recursos } \\
\text { humanos }\end{array}$ & Alta & Alta & Alta & Alta & Alta & Alta \\
\hline $\begin{array}{l}\text { (ii) Oferta de serviços } \\
\text { especializados }\end{array}$ & Alta & Alta & Alta & Alta & Alta & Alta \\
\hline (iii) Redes de informação & Alta & Alta & Alta & Alta & Alta & Alta \\
\hline $\begin{array}{c}\text { (iv) Vendas } \\
\text { externas/marketing }\end{array}$ & Alta & Média & Média & Alta & Média & Média \\
\hline (v) Compra de insumos & Difícil & Média & Baixa & Média & Baixa & Baixa \\
\hline (vi) Financiamento & Baixa & Média & Alta & Média & Baixa & Baixa \\
\hline (vii) Infra-estrutura & Baixa & Baixa & Alta & Baixa & Baixa & Baixa \\
\hline (viii) Logística & Alta & Alta & Alta & Baixa & Baixa & Baixa \\
\hline (ix) Ação política & Alta & Alta & Alta & Alta & Baixa & Baixa \\
\hline $\begin{array}{c}\text { (x) Desenvolvimento de } \\
\text { produto }\end{array}$ & Difícil & Média & Baixa & Baixa & Alta & Alta \\
\hline $\begin{array}{c}\text { (xi) Desenvolvimento de } \\
\text { processo }\end{array}$ & Difícil & Alta & Baixa & Baixa & Média & Alta \\
\hline (xii) Assessoria em gestão & Baixa & Média & Baixa & Alta & Alta & Média \\
\hline
\end{tabular}

213 Fonte: Baseado em NARETTO, Nilton; BOTELHO, Marisa dos Reis \& MENDONÇA, Maurício "Trajetória das políticas públicas para pequenas e médias empresas no Brasil: do apoio individual ao apoio a empresas articuladas em arranjos produtivos locais”. IPEA. Planejamento e Polícias Públicas. n. ${ }^{2} 27$, jun./dez. 2004. A maior parte das observações adiante é baseada neste trabalho. 
(i, ii e iii) Capacitação de recursos humanos, oferta de serviços especializados e instalação de redes de informação: aqui se tem as ações cuja implementação é providencial. Isso pode ser feito mediante o fortalecimento dos esquemas de representatividade das associações locais, tornando-as núcleos de troca de experiências e de prestação de serviços de interesse comum (principalmente de treinamento e assistência tecnológica). Dessa maneira, tem-se criado uma esfera mínima de compartilhamento de ações que favorece a criação de laços de confiança entre os agentes, portanto, são elementos do APL que mais facilmente podem ser inseridos em programas de ação concertada.

(iv) Ações relacionadas a vendas externas e marketing se mostram viáveis na medida em que, nos arranjos horizontalizados, tem-se uma identidade de produtos originada no Arranjo e cuja promoção é de interesse comum das empresas. Aqui entrariam as ações de criação de marcas regionais e denominação de origem, para o que podem contribuir as entidades de classe. Além disso, a atuação de centro de pesquisa se faz importante no desenvolvimento de tecnologias que permitam aprimorar os produtos base do Arranjo e diferenciá-los. Em arranjos horizontalizados, essas medidas, contudo, podem sofrer resistências, pois a(s) empresa(s) líder(es) da cadeia, que normalmente comandam a produção a montante, podem perder seus fornecedores para a concorrência. Também é de se levar em conta a possibilidade de que, dentre as empresas do Arranjo, algumas se destaquem, diferenciando-se das demais firmas e, por conseguinte, reduzindo sua propensão a cooperar.

(v) Em relação à compra de insumos, também aqui as práticas cooperativas tendem a se fazer mais presentes diante da existência de interesses comuns dos agentes na realização da aquisição conjunta, ou seja, ela se mostra mais viável em arranjos horizontalizados. O principal benefício advindo dessa prática é o incremento do poder de barganha das firmas por melhores condições de compra resultante do maior volume adquirido na figura de um único demandante - o qual pode adquirir a forma de um consórcio de compras, uma associação ou uma cooperativa, senão mesmo uma união informal das empresas tendo em vista esse objetivo específico.

(vi) No que diz respeito aos financiamentos, não se vislumbra a possibilidade de, num arranjo horizontalizado, as empresas figurarem como concedentes de créditos às firmas concorrentes, conquanto elas possam consorciar-se na constituição de fundos de aval ou na formação de associações de garantia de crédito. Em arranjos verticalizados, 
todavia, pode ser interessante às empresas líderes conceder crédito diretamente às firmas fornecedoras ou figurar como garantidoras do crédito que estas tomem. De todo modo, mais provável é que este instrumento de incentivo seja oportunizado pelo poder público, na figura de um banco ou agência de fomento. Instituições de apoio institucional e assistência comercial têm atuação restrita nessa seara, tendendo a contribuir, no máximo, com subvenções de projetos específicos de interesse coletivo. Centros de pesquisa, por sua vez, certamente não têm como objetivo conceder crédito às empresas, conquanto a atividade por eles desenvolvida possa ter enorme valor pecuniário.

(vii) Em relação ao provimento de infra-estrutura e demais bens públicos, a prevalência do papel do Estado se explica pelo simples fato de que se trata de um encargo que lhe compete justamente em razão de ser pouco provável que outros agentes o façam. $\mathrm{O}$ poder público é juridicamente vocacionado a cuidar de tal tarefa. Quando muito, as empresas do arranjo podem se unir em parceria com o poder público para realizarem melhorias em obras de infra-estrutura das quais possam tirar proveito direto (asfaltamento de uma estrada, expansão na rede elétrica ou de irrigação).

(viii) No que toca à logística, tem-se aqui um aspecto de interesse comum das empresas, estejam elas em arranjos horizontalizados ou em arranjos verticalizados. No primeiro caso, o consorciamento das empresas para a gestão de transportes, de compras, de estoques e de movimentação de insumos comuns pode ser possível se não houver competição pela comercialização dos produtos finais das empresas. Já os arranjos verticalizados não só têm aptidão para a cooperação logística como a própria estruturação da cadeia produtiva em esquemas de subcontratação é marcada por esse caráter - em esquemas produtivos do tipo just-in-time, nos quais as empresas líderes atuam em estreita relação com as fornecedoras, exigindo coordenação em relação a processamento de pedidos, movimentação de materiais, gerenciamento de informações, manutenção de estoques e transporte. Ainda que no caso dos arranjos verticais se verifique uma relação de subordinação entre as firmas, regulada por mecanismos contratuais, fato é que eventuais resistências das firmas em atuar de maneira cooperativa em relação à logística acaba por trazer prejuízos a ambas as partes. Especificamente em relação à logística de transportes, cabe assinalar a possibilidade de participação do poder público no provimento de infraestrutura.

(ix) Quanto à ação política, aqui entendida como a reunião dos agentes a fim de pleitear medidas governamentais de interesse do Arranjo, a cooperação se beneficia do 
fator da inexistência de limites prévios às reivindicações. Assim é que, mesmo havendo algum grau de discrepância no que se entenda prioritário para o APL (algumas firmas podem reclamar acesso ao crédito, enquanto outras podem considerar mais urgente o provimento de infra-estrutura ou a instalação de um centro de formação de mão-de-obra), nada impede que todas as demandas sejam reunidas para serem apresentadas às autoridades públicas. Nesse sentido, faz-se fundamental a figura da associação de classe, bem como a atuação conjunta das empresas com o poder local a fim de demonstrar o interesse coletivo na reivindicação apresentada.

(x) Em matéria de desenvolvimento de produtos, a cooperação entre firmas em Arranjos horizontalizados só se faz possível diante da necessidade de diluição de custos do processo e da possibilidade de posterior compartilhamento de seus resultados, pois, do contrário, interessaria às firmas somente a obtenção do produto inovador capaz de lhe garantir vantagem competitiva. Em Arranjos verticalizados, todavia, o desenvolvimento de um produto por um fornecedor pode interessar à empresa líder caso isso implique uma vantagem do produto final que comercializa, razão pela qual pode haver associação das firmas para tal propósito. Esse aspecto não tem pertinência com as atividades do poder público local tampouco com as associações de classe - salvo se estas estiverem engajadas com as instâncias em que as práticas cooperativas de desenvolvimento de produtos tenham como local privilegiado, quais sejam, entidades de apoio gerencial e comercial e centros de pesquisa. Principalmente esses últimos prestam-se a tal finalidade.

(xi) O desenvolvimento de processo segue uma lógica parecida com a do desenvolvimeno de produto.Isso porque ele também pode representar uma vantagem competitiva, que dificulte sua adoção em Arranjos horizontalizados e facilite seu emprego nos verticalizados, com a peculiaridade de, pelo fato de apresentar menores riscos, ter a adoção facilitada. O desenvolvimento de processo não se sujeita propriamente a risco de insucesso, eis que se trata de adotar ou não uma nova metodologia de produção, sendo que a incerteza se reduz a eventual pouca eficácia em produtividade. Assim é que não se afigura incomum as empresas líderes tomarem a iniciativa de levar a demanda das MPMEs fornecedoras aos centros de pesquisa e entidades de apoio institucional. Associações de classe e poder público local não dominam a atividade em questão, de modo que pouco podem contribuir nesse sentido.

(xii) Por fim, no que toca ao desenvolvimento e disseminação de técnicas de gestão, o protagonismo se dá na figura das entidades de classe e das instituições de apoio. 
Por vezes, iniciativas como seminários e cursos voltados à gestão das empresas filiadas fazem as associações figurarem praticamente como provedoras de serviços educacionais. Entretanto, o exemplo mais contundente de ação voltada ao desenvolvimento de práticas de gestão pode ser encontrado nas incubadoras de empresas.

Conquanto esse amplo espectro no qual as ações cooperativas podem se dar ajude a evidenciar a possibilidade da atuação conjunta das empresas aglomeradas, fato é que as práticas associativas sempre dependem de fatores de difícil identificação e mensuração: confiança e propensão psicológica a cooperar. Por vezes, nem mesmo a existência de lideranças atuantes consegue ajudar na cooptação de forças tendo em vista um objetivo comum aos agentes. Wilson SUZIGAN, João FURTADO \& Renato GARCIA ilustram com dois casos como a ação deliberada do Estado na criação de mecanismos de governança e cooperação podem ser totalmente inócuos ou, do contário, apresentar grande eficácia $^{214}$. Na opinião desses autores, o fator determinante é a cultura associativista local, que pode muito bem albergar iniciativas dessa natureza ou repeli-las, como no caso das aglomerações das cidades paulistas de Franca (calçados masculinos e couro) e de Votuporanga (móveis).

No primeiro caso, apesar da sequência de tentativas de inserção de mecanismos de cooperação mediante o estabelecimento de um aparato de governança, não se conseguiu êxito em tal propósito, principalmente pela dificuldade de alinhar interesses das pequenas e grandes empresas. Quando o sindicato das indústrias local tentou criar uma marca local, as grandes empresas viram em tal iniciativa o risco de perderem mercado em razão da identificação de produtos de outras firmas com os seus.

Já quando da criação de um consórcio de compras de insumos estratégicos por pequenas empresas visando fazer frente ao poder de mercado dos grandes fornecedores, estes últimos reagiram passando a oferecer produtos diretamente às firmas consorciadas a preços inferiores aos ofertados ao consórcio; desse modo, rapidamente se quebrou a confiança entre as empresas e o consórcio encerrou-se. Por fim, a falta de eficácia de um ambicioso programa intentado pela FIESP ("Projeto Cluster") em 1999 aumentou no empresariado local a desconfiança sobre propostas oriundas do governo ou entidades de classe. Assim é que, em Franca, as economias externas existentes, propiciadoras da

214 "Estruturas de Governança em Arranjos ou Sistemas Locais de Produção". Gestão e Produção (UFSCar), v. 14, p. 425-439, 2007. 
aglomeração produtiva, parecem ocorrer e subsistir a despeito da atuação de uma governança institucionalizada ${ }^{215}$.

No caso de Votuporanga, a criação de uma instância de coordenação mostrou-se decisiva na transformação da produção local, resultando na melhoria da qualidade dos produtos, na introdução do elemento tecnológico e na qualificação da mão-de-obra na estratégia competitiva das empresas.

Em meados de 1993 um grupo de empresas contratou um profissional para atuar como coordenador de ações coletivas locais. O principal problema seria desenhar estratégias capazes de fazer os interesses das empresas convergirem, pois, em princípio, a grande heterogeneidade do porte empresarial e do que se produzia na cidade não favorecia a articulação interfirmas. Havia um quadro desfavorável à divisão do trabalho e formação de cadeia produtiva, agravado pelo fato de que os fornecedores de insumos eram grandes empresas sem ligação com o local.

Todavia, por outro lado, não havia nas entidades de classe empresas líderes ou detentoras de poder de mercado ou de poder político capazes de criar tensões. A grande maioria das empresas não estava subordinada a esquemas rígidos de comercialização, escoando seus produtos por intermédio de representantes comerciais. Contudo, a cidade contava com uma história de cooperação informal entre as empresas, tendo sido relatado como prática comum o empréstimo de matérias-primas e de máquinas. Num caso emblemático, uma empresa que teve suas instalações destruídas por incêndio rapidamente voltou à atividade por conta da solidariedade dos proprietários de outras firmas. A atitude cooperativa também se revelou na criação, em 1998, da Cooperbems - Cooperativa de Trabalho Geral e Bem Social, que reuniu a mão-de-obra que prestava serviços às empresas de modo pouco formalizado.

\footnotetext{
215 "Não surpreende, portanto, que não haja em Franca qualquer estrutura de governança local, nem interesse em criar tal estrutura. As grandes empresas exportadoras são coordenadas por compradores internacionais. Essas empresas, juntamente com outras grandes empresas fabricantes de calçados que operam no mercado interno, e fornecedores de insumos estratégicos, detêm o controle político da entidade de classe e têm poder político e econômico para impedir ações que não sejam de seu interesse. Os outros segmentos têm autonomia, mas não têm suficiente organização nem poder econômico ou político. Tudo indica, que as vantagens competitivas proporcionadas por economias de aglomeração são tão fortes em Franca, que dispensam ações conjuntas ou iniciativas coletivas que visem maior eficiência do sistema produtivo local, que ademais, tem apresentado vigoroso desempenho em termos de crescimento e razoável dinamismo tecnológico". SUZIGAN, Wilson ; FURTADO, João \& GARCIA, Renato. "Estruturas de Governança em Arranjos ou Sistemas Locais de Produção". Gestão e Produção (UFSCar), op. cit., p. 432.
} 
$\mathrm{O}$ que se verificou no caso de Votuporanga foi um engajamento das instituições locais, principalmente a associação de classe (AIRVO - Associação Industrial da Região de Votuporanga, que incorporou o Sindimob - Sindicato das Indústrias do Mobiliário de Votuporanga, atuante agora como um departamento)e a Prefeitura local (que contava com a FUVEC - Fundação Votuporanguense de Educação e Cultura), a partir da ação do coordenador.

Em suma, o trabalho desse profissional foi fundamental para viabilizar ações que incrementaram a tendência à associação e à cooperação de empresas e instituições públicas e privadas locais, quais foram: contratação de consultorias em gestão empresarial (gestão de custos, layout, processos de produção, marketing); implantação de um programa da qualidadeque contou com técnicos treinados atuando diretamente nas empresas; criação de um curso superior de tecnologia de produção moveleira na FUVEC. Além disso, criou-se, em 2001, o CEMAD - Centro Tecnológico de Formação Profissional da Madeira e do Mobiliário de Votuporanga, destinado a formar mão-de-obra especializada e incorporar tecnologias de processo e de produto. Além de oferecer cursos técnicos e profissionalizantes, o CEMAD possibilita às empresas locais o acesso à infra-estrutura especializada para $\mathrm{P} \& \mathrm{D}$, ao design de produção moveleira, aos serviços de assessoria técnica e tecnológicae de gestão da produção, à informação tecnológica e aos ensaios laboratoriais. Os autores relatam que a criação do CEMAD, concebido pelo SENAI/São Paulo, foi claramente um processo dependente da ação coletiva comandada pelo agente coordenadore apoiada pela AIRVO/Sindimob, contando com a parceria da FUVEC.

O agente coordenador cuidou de sensibilizar e atrair entidades públicas de fomento - BNDES, CNPq, o Ministério da Educação e o Banco Interamericano de Desenvolvimento. Os resultados não demoraram a aparecer e foram significativos. No ano de 2000, de um total de 14 empresas moveleiras com certificação ISO 9002 no Brasil, 6 eram de Votuporanga, sendo que 15 outras empresas locais estavam em processo de certificação. Além disso, presenciou-se uma maior preocupação das empresas com design e desenvolvimento de produtos, prospecção de mercados, diferenciação de produtos para nichos de mercado nas classes de renda mais elevada e com a exportação. A experiência mostrou-se tão exitosa que o modelo de governança e de instrumentos de incentivo foi adotado em Mirassol (SP) e Macapá (AP).

Esses exemplos reforçam a ideia de que, por se tratar de uma política de alcance local, a coordenação tem de se dar no âmbito local. O fomento aos APLs depende de um 
conhecimento efetivo da realidade local, bem como do reconhecimento, pelos seus partícipes, da figura responsável pela coordenação das iniciativas coletivas:

A coordenação das ações é ainda mais relevante quando realizadas no lócus onde concretamente as políticas são implementadas, de modo a evitar sobreposições e conflitos que, além de constitutírem fator de desestímulo e desmobilização dos atores locais, podem ocasionar perda de credibilidade das políticas, iniciativas e organismos responsáveis por sua implementação. Essa coordenação de ações no âmbito local depende, em grande medida, da difusão e da transparência das informações entre os diversos atores, bem como de sua disposição em cooperar e superar divergências. Uma outra questão correlata refere-se à importância de liderenças locais que exerçam o papel de agregar atores e iniciativas. (...) A presença de indivíduos que atuem como lideranças locais, pertencentes a empresas aou a organismos de promoção, contribui, de modo decisivo, para a coesão, a integração e a coordenação das iniciativas existentes no APL. A emergência dessas lideranças requer a existência de uma conjunção de fatores que contribuam para conformar um ambiente local propício à efetividade de suas ações e, desse modo, favoreçam seu fortalecimento e legitimidade ante o conjunto de atores atuantes no APL. A existência de divergências e conflitos entre esses atores não deve ser vista como uma contraprova desse fato, mas como parte da dinâmica de interação e de negociação de interesses ${ }^{216}$.

No mesmo sentido assinalam Clélio C. DINIZ, Fabiana SANTOS \& Marco CROCCO ao tratar das políticas de apoio aos APLs:

De fato, o aspecto local do APL impõe uma dinâmica bastante diferenciada em relação aos tradicionais instrumentos de políticas industrial e regional, pois confere às organizações do governo local um papel decisivo na implementação das políticas. Por atuar mais próximo do APL, governos locais possuem melhores condições de entender a dinâmica local - dificuldades, necessidades e culturas - facilitando, assim, a coordenação dos objetivos da política. Em outras palavras, a descentralização na formulação e implementação das políticas é essencial para o desenvolvimento dos APLs ${ }^{217}$.

\footnotetext{
${ }^{216}$ LEMOS, Cristina, ALBAGLI, Sarita \& SZAPIRA, Marina. "Políticas de promoção de arranjos produtivos locais no Brasil: evolução recente e desafios atuais” em LASTRES, Helena \& CASSIOLATO (org), José E. Estratégias para o Desenvolvimento: um enfoque sobre Arranjos Produtivos Locais do Norte, Nordeste e Centro-Oeste Brasileiros. Rio de Janeiro, E-papers, 2006, pp 249-266.

217 “Conhecimento, Inovação e Desenvolvimento Regional”. Relatório do Projeto Diretrizes para Formulação de Políticas de Desenvolvimento Regional e de Ordenação do Território Brasileiro. Disponível em: http://www.integracao.gov.br/publicacoes/desenvolvimentoregional/publicação, p. 40.
} 
No que se refere à presença de um agente coordenador no âmbito do APL, vale citar que a Lei Complementar n. 128 criou a figura do Agente Local de Desenvolvimento, profissional designado pelo poder público municipal para cuidar das políticas de apoio a microempresas e empresas de pequeno porte, com suporte do $\mathrm{MDIC}^{218}$. Apesar de o diploma em referência não fazer menção à política de APLs, ações em prol dos Arranjos podem ser realizadas no bojo das políticas previstas no Estatuto Nacional da Microempresa e da Empresa de Pequeno Porte. Certo é que a existência de estruturas burocráticas profissionalizadas, que contem com um grupo de profissionais de áreas diversas, tende a oferecer um surporte de melhor qualidade à elaboração e execução de qualquer política pública. Mas não é de se desprezar a ação de um único profissional, eis que, se ele puder contar com o apoio das instituições locais, poderá contribuir para uma melhor articulação destas tendo em vista a criação das ações coletivas.

Fernando Pimentel PUGA ressalta que a existência de uma rede de cooperação possibilita a aplicação do que ele chama de "formas coletivas de apoio às empresas",219. Este autor afirma que as políticas de apoio aos APLs exige estratégias que abarquem um conjunto de firmas; daí o apoio governamental não poder se estruturar de maneira unilateral ou de cima para baixo, mas sim provocar a mobilização das empresas; em razão disso, ele aponta alguns procedimentos que devem preceder as políticas de incentivo ${ }^{220}$ :

(i) conhecimento do porte das empresas e da relação de cooperação existente, a fim de identificar possíveis empresas que possam discrepar das demais e verificar sua tendência figurar como líder ou, do contrário, impedir iniciativas coletivas;

(ii) verificação da existência, representatividade e atuação de agentes que possam colaborar na formulação e implementação das políticas (associações de classe,

218 “Art. 85-A. Caberá ao Poder Público Municipal designar Agente de Desenvolvimento para a efetivação do disposto nesta Lei Complementar, observadas as especificidades locais. $\S 1^{o}$ A função de Agente de Desenvolvimento caracteriza-se pelo exercício de articulação das ações públicas para a promoção do desenvolvimento local e territorial, mediante ações locais ou comunitárias, individuais ou coletivas, que visem ao cumprimento das disposições e diretrizes contidas nesta Lei Complementar, sob supervisão do órgão gestor local responsável pelas políticas de desenvolvimento. $\S 2^{\underline{o}}$ O Agente de Desenvolvimento deverá preencher os seguintes requisitos: I - residir na área da comunidade em que atuar; II - haver concluído, com aproveitamento, curso de qualificação básica para a formação de Agente de Desenvolvimento; e III - haver concluído o ensino fundamental. $\S 3^{o}$ O Ministério do Desenvolvimento, Indústria e Comércio Exterior, juntamente com as entidades municipalistas e de apoio e representação empresarial, prestarão suporte aos referidos agentes na forma de capacitação, estudos e pesquisas, publicações, promoção de intercâmbio de informações e experiências."

${ }^{219}$ PUGA, Fernando P. Alternativas de apoio a MPMEs localizadas em Arranjos Produtivos Locais. Rio de Janeiro: BNDES, 2003. (Textos Para Discussão, 99), p. 17.

${ }^{220}$ Baseado em PUGA, Fernando P. Alternativas de apoio a MPMEs localizadas em Arranjos Produtivos Locais. Rio de Janeiro: BNDES, 2003. (Textos Para Discussão, 99), pp 17-18. 
instituições de ensino, serviços de apoio empresarial, instituições financeiras), o que colabora com a redução dos encargos estatais e o aumento da eficácia das ações governamentais;

(iii) avaliação das demandas das empresas, medida essa que é fundamental para a percepção das possibilidades do fortalecimento dos vínculos do Arranjo e, principalmente, da adersão das firmas às das políticas de fomento.

Daí a importância do tema da governança para as políticas públicas de promoção dos APLs: o Estado ou qualquer outra instituição capaz de agir com neutralidade em relação ao interesse de uma firma face às demais, operando como um árbitro, surge como agente capaz de estruturar esquemas de organização do arranjo. A presença dessa figura arbitral é importante porque possibilita uma distribuição equânime de encargos e benefícios, sem o que as práticas cooperativas podem restar desistimuladas em razão da percepção de que algumas firmas estejam usufruindo de maiores vantagens em face das demais.

Por isso, para Fábio S. ERBER, partindo-se do pressuposto de que as empresas líderes de um Arranjo têm maior capacidade de se beneficar da eficiência coletiva e absorver melhor os impactos das imperfeições de mercado, "o corolário para as políticas públicas seria buscar induzir essas grandes empresas a contribuir para a constituição dos ativos de uso comum pelas PMEs partícipes do APL"221. Segundo esse autor, entretanto, o desafio dessa política reside no fato de que ela se faz mais necessária onde ela é menos provável de se efetivar. O exemplo seria uma aglomeração em que se verificasse uma grande hierarquização entre uma empresa líder multinacional (detentora da comercialização e definidora das especificações do produto e da tecnologia utilizada em sua manufatura) e seus fornecedores de menor porte, pela qual as MPMEs estariam expostas a risco de alteração súbita e radical das relações de comercialização. A menos que esses fornecedores detivessem um ativo muito específico e de difícil replicação, a empresa líder poderia até mesmo se instalar em outra localidade, deixando para trás uma cadeia de firmas dependentes do modelo de negócios até então adotado. Para que a eficiência coletiva venha à tona, pois, e a fim de que se instaure um verdadeiro APL, cabe ao Estado se valer de instrumentos de fomento em favor da empresa líder, induzindo sua permanência em regime de colaboração com as demais empresas, o que se pode fazer, por exemplo, por

221 "Eficiência coletiva em arranjos produtivos locais industriais: comentando o conceito". Nova Economia. Belo Horizonte: UFMG, n. ${ }^{\circ}$ 18, jan./abr. 2008, p. 27. 
intermédio de incentivos fiscais e/ou crédito, concomitantemente à criação e manutenção de instituições que possam ser úteis às empresas como um todo (os supra citadas centros de pesquisa, de assistência técnica, de formação de empreendedores, de apoio à exportação etc.). Essa sugestão de estratégia demonstra como a criação de um mecanismo de governança pode (ou deve) se dar concomitantemente à instalação de instrumentos que induzam à cooperação interfirmas.

Para J. HUMPHREY e H. SCHMITZ, a governança diz respeito às relações estabelecidas entre as empresas, reciprocamente, bem como entre elas e outras instituições capazes de exercer coordenação. Esses autores acentuam que, além do mercado, a coordenação das atividades econômicas deriva de redes e de situações de hierarquia e quase-hierarquia, admitindo-se governança de caráter público e privado ${ }^{222}$. Renato $\mathrm{R}$. CAMPOS propõe uma tipologia de sistemas de governança baseada na divisão do trabalho e no número e tamanho das empresas ${ }^{223}$. A tabela a seguir esquematiza a correspondência entre o aumento da complexidade da governança e o grau de divisão do trabalho no interior do Arranjo.

\begin{tabular}{|c|c|c|c|c|}
\hline Governança & $\begin{array}{c}\text { Principalmente } \\
\text { MPMes }\end{array}$ & $\begin{array}{c}\text { Grandes Firmas e } \\
\text { Presenças de } \\
\text { MPMes }\end{array}$ & $\begin{array}{c}\text { Principalmente } \\
\text { MPMes }\end{array}$ & $\begin{array}{c}\text { Grandes Firmas e Presenças de } \\
\text { MPMes }\end{array}$ \\
\hline $\begin{array}{c}\text { Formas } \\
\text { predominantes de } \\
\text { governança }\end{array}$ & $\begin{array}{c}\text { Predominância de } \\
\text { redes }\end{array}$ & $\begin{array}{c}\text { Predominância de } \\
\text { hierarquia }\end{array}$ & $\begin{array}{l}\text { Predominância } \\
\text { de redes }\end{array}$ & Predominância de hierarquia \\
\hline
\end{tabular}

A isso se poderia acrescentar que a complexidade da governança também é determinada pela quantidade de entidades governamentais e de classe que compõe o arranjo. Embora a introdução de agentes governamentais possa se dar com o fito de

${ }^{222}$ HUMPHREY, J. \& SCHMITZ, H. "Governance and upgrading: linking industrial cluster and global value chain research". IDS Working Paper 120. Brighton: Institute of Development Studies, University of Sussex, 2000.

${ }^{223}$ CAMPOS, Renato R. Ampliando espaços de aprendizagem: um foco para políticas de estímulos aos arranjos produtivos locais. Uberlândia, 2004. Anais do IX Encontro Nacional de Economia Política, Disponível em http://www.sep.org.br/artigo/ixcongresso14.pdf. 
instaurar governança, isso não ocorre necessariamente, pois que uma entidade de fomento pode se inserir no Arranjo para a execução de um programa específico que não envolva uma ação de pretensão organizatória.

Talvez a presença de entidades governamentais seja o fator principal a ensejar mecanismos de governança, pois, do ponto de vista das empresas do arranjo, a falta de coordenação entre os agentes públicos pode provocar uma sensação de instabilidade e desorientação prejudicial às práticas cooperativas. Considerando, portanto, agentes públicos e privados no âmbito do arranjo, pode-se concluir que algumas atividades são mais dependentes de esquemas de governança que estimulem práticas cooperativas.

No tópico a seguir, portanto, trata-se-á da conjugação das atividades das instituições públicas no apoio aos APLs, principalente do ponto de vista da política desenhada no plano federal - como ela pode estabelecer conexões e se mostrar próxima à escala local em que tem de ser implementada?

\subsubsection{Formas de atuação conjugada das entidades públicas}

Independente da tipologia de identificação e caracterização de APLs que se adote, não há como prescindir de uma noção de proximidade geográfica como critério determinante. As empresas de um Arranjo situam-se e espraiam os efeitos da atividade econômica em territórios que se submetem ao influxo de normas das três instâncias federativas, quando não se encontram na imbricação de mais de um Município ou Estado.

Disso decorre que a base territorial do APL é relevante porque induz à determinação de competência das entidades públicas. A aglomeração pode ser economicamente significativa apenas para poucos municípios, ou, então, fazer jus a benefícios de uma entidade de desenvolvimento regional, ou, ainda, ser relevante para a formulação de uma política de alcance nacional. A dimensão espacial importa e repercute efeitos, de modo que cabe avaliar a maneira pela qual isso pode se traduzir em fomento público. Noutros termos, a questão é saber como a escala territorial atrai ou repele as entidades governamentais.

Um Município pode prescindir da ajuda de outro Município ou de entidades estatais e federais para apoiar um APL localizado em seu território. Mas se os benefícios de tal 
política se fizerem sentir nos Municípios circunvizinhos ou se forem de grande importância estadual ou mesmo federal, ter-se-á justificativa para que o erário local não arque sozinho com tal dispêndio. Portanto, quase sempre se verifica a possibilidade (ou necessidade) de atuação conjunta das três esferas federativas - até porque a política de promoção de APLs também foi alçada à esfera federal, porquanto integra a política de desenvolvimento produtivo e tem nítida identificação com as políticas de desenvolvimento regional.

Os Estados, por sua vez, também possuem políticas dessa natureza e cumprem importante papel de apoio financeiro e técnico aos Municípios nessa seara (como, de resto, a União em relação à grande maioria dos Estados). Essa subordinação econômica e técnica dos entes federativos, como se vê, vai no caminho inverso do grau de proximidade que possuem com a questão local: a União congrega entidades dotadas de grande potencial de intervenção (bancos, Embrapa, Sebrae), mas depende da intermediação de Estados e Municípios para apreender a realidade local.

De fato, a política federal de apoio aos APLs parece ter assumido a premissa de que o protagonismo da governança do Arranjo deve ficar com autoridades locais ${ }^{224}$. Esse pressuposto se fez presente desde o início da formatação dos trabalhos do GTP-APL. Isto porque, inicialmente, o GTP-APL tratou de realizar um levantamento dos Arranjos existentes junto a entidades governamentais e não governamentais.

Em 2004, baseado nas informações de 11 instituições, chegou-se ao número de 460 APLs no país; em 2005, tendo sido ampliado o GTP-APL e, portanto, com o consequente aumento da base de arranjos referenciados em cada instituição, identificaram-se 957 arranjos. Posteriormente, elegeram-se no máximo até 5 APLs por Estado para fins de aplicação das medidas de incentivo, sendo que a eleição foi ratificada pelos parceiros estaduais, po intermédio do Fórum dos Secretários Estaduais de Indústria e Comércio. Somando-se essa lista a um grupo de 11 Arranjos pilotos com que o GTP-APL contava desde 2004, tem-se 141 Arranjos. Em 2007, cada núcleo estadual pôde indicar mais 5 APLs, de modo que se passou a contar 261 considerados prioritários.

Não só porque a União não tem o aparato burocrático suficiente para tutelar todas as ações que se passam em cada Arranjo, mas também porque a escala local da política pública em questão não se afigura apropriada para a ação federal é que a política de apoio aos APLs foi concebida de modo a fazer com que o planejamento da ação governamental

${ }^{224}$ Essa descrição sobre as ações iniciais da política federal de incentivo aos APLs é extraída do Manual de Apoio aos Arranjos Produtivos Locais. Brasília: MDIC, 2004. 
voltada a cada Arranjo fosse concebido a partir do diagnóstico e da demanda dos agentes locais, intermediados por instâncias estaduais ${ }^{225}$ - os Núcleos Estaduais $(\mathrm{NE})^{226}$. A responsabilidade do NE é intermediar as demandas dos APLs em cada Estado e buscar, no âmbito local, as articulações institucionais necessárias ao atendimento dessa demanda.

Os NEs devem ser compostos por representantes das entidades capazes de planejar e executar os Planos de Desenvolvimento. Daí a importância da presença de agentes públicos dotados de poder decisório (secretarias de governo, preferencialmente as imbuídas das competências relativas à atividade de fomento) e demais agentes com que normalmente estejam engajados em ações em prol do APL.

O Termo de Referência do GTP-APL indica que haja pelo menos um representante de cada um dos seguintes segmentos: governo estadual (que atue com a abordagem de APL em seu Estado); sistema $\mathrm{S}$; instituição financeira; setor empresarial; sistema C\&T e trabalhadores.De acordo com o Termo de Referência para Política Nacional de Apoio ao Desenvolvimento de Arranjos Produtivos Locais, os APLs eleitos, com o apoio dos NEs, deveriam produzir um Plano de Desenvolvimento Preliminar - PDP, cuja função seria expressar:

o esforço de reflexão e de articulação local que contemple informações a respeito dos desafios dos APLs e suas oportunidades de negócio; as ações que estão sendo implementadas ou que precisam ser desenvolvidas com vistas a transformar essas oportunidades em investimentos eos investimentos que precisam ser fortalecidos para o desenvolvimento sustentável das localidades ${ }^{227}$.

\footnotetext{
225 "Face às limitações operacionais do GTP e dado que as políticas públicas municipais, estaduais ou regionais exercem grande influência sobre as condições estruturantes dos arranjos, o envolvimento de setores das administrações públicas estaduais no processo de acolhimento de propostas dos arranjos produtivos, bem como nas respectivas articulações e apoios institucionais decorrentes, é fundamental para estimular e comprometer as lideranças dos APLs nos processos de elaboração dos Planos de Desenvolvimento e conseqüentes articulações institucional e empreendedora que viabilizem os investimentos planejados. O proposto evidencia o caráter de descentralização, de colaboração entre os entes federados, o protagonismo institucional e dos atores dos arranjos, bem como envolve os níveis locais e estaduais nessa articulação, integrando suas estratégias. (...). Nesse contexto, o maior desafio do GTP APL será fazer com que os técnicos, e suas respectivas instituições em nível estadual, assumam o comando do processo de desenvolvimento e apoio ao APL do seu Estado". Manual de Apoio aos Arranjos Produtivos Locais. Brasília: MDIC, 2006, p. 19.

226 “O Núcleo Estadual - NE tem o papel de fomentar as demandas dos APL locais, além de analisar suas propostas e promover articulações institucionais com vistas ao apoio demandado. Esses Núcleos devem ser preparados para executarem as Rodadas de Apreciação do Plano de Desenvolvimento, que contempla discussões sobre as ações constantes do PDP e promoção de articulação para se chegar a uma 'Agenda de Compromisso' que delineará a estratégia de atuação integrada para cada APL". Orientação Aos Núcleos Estaduais. Brasília: MDIC. 2006, p. 07.

${ }^{227}$ Manual de Apoio aos Arranjos Produtivos Locais. Brasília: MDIC, 2006, p. 18-19. Ainda de acordo com esse documento, o conteúdo do PDP deveria contemplar: "1. Construção de uma base institucional e operacional no âmbito do GTP APL, a partir do envolvimento de suas instituições e seus interlocutores
} 
A elaboração do PDP, portanto, também pode ser entendida como um momento em que se deve verificar a atuação da governança do APL, na medida em que ele tem de apresentar as medidas aptas a beneficar o conjunto dos atores locais. Dificilmente os governos estaduais possuem estruturas burocráticas voltadas a cada Arranjo específico, de modo que a participação dos governos municipais na aglutinação dos interesses que se discutirão na formulação do PDP se impõe.

Os NEs devem estar preparados para verificar a conformidade dos PDPs com o Termo de Referência para submetê-los às instituições do GTP-APL, a quem cabe fazer uma avaliação quanto ao tipo e à forma de apoio que poderão prestar. Vale ressaltar aqui que não existem critérios quaisquer de avaliação das reivindicações constantes dos PDPs, afigurando-se decisão complementamte discricionária o acolhimento da demanda apresentada à entidade federal partícipe do GTP-APL. O conjunto das manifestações das instituições partícipes do GTP-APL, em resposta à demanda dos APLs, é reunido e repassado de volta aos NEs para que se inicie a elaboração de uma Agenda de Compromisso $^{228}$ com os agentes locais.

Também é de se reparar o fato de que a manifestação da entidade federal componente do GTP-APL não significa um compromisso firme de realização de investimentos, mas apenas o anúncio de que o atendimento das demandas se afigura viável e que se envidarão esforços para a sua realização ${ }^{229}$.

O seguinte quadro ilustra a distribuição de competências entre as instâncias envolvidas no processo:

locais; 2. Construção de uma base na localidade - o protagonismo dos atores locais - o GTP APL não interfere diretamente na promoção da governança ; 3. Construção de bases institucionais para a atuação integrada das políticas públicas, com a complementaridade de instrumentos institucionais, com vistas ao atendimento das demandas dos APLs".

228 “3. Agenda de Compromisso. Essa Agenda coloca as entidades proponentes (Governança do APL) $e$ provedoras (NE e GTP), incumbidas de promoverem as articulações e negociações, que viabilizem os investimentos e ações previstas nos Planos de Desenvolvimento respectivos. Ou seja, não deve ser traduzida a aprovação dos Planos de Desenvolvimento, por parte do GTP APL e do NE, como garantia dos investimentos e serviços solicitados, mas ficam os envolvidos comprometidos, publicamente, com a viabilização dos mesmos, a dependerem dos recursos e prioridades de cada instituição envolvida, principalmente dos empreendedores dos APLs". Orientação Aos Núcleos Estaduais. Brasília: MDIC. 2006, p. 9.

229 Termo de Referência para Política Nacional de Apoio ao Desenvolvimento de Arranjos Produtivos Locais, Brasília: MDIC, 2004. p. 28. O seguin 


\begin{tabular}{|l|l|}
\hline \multicolumn{2}{|c|}{ Papel das instâncias federais e estaduais envolvidas na estratégia } \\
\hline \multicolumn{1}{|c|}{ Instância } & \multicolumn{1}{c|}{ Responsabilidades } \\
\hline Do Núcleo Estadual: & Promover a Reunião de Sensibilização nos APLs selecionados no seu \\
& Estado para provocar a elaboração dos PDPs; \\
& Acompanhar a elaboração dos PDPs; \\
& Receber e apreciar os PDPs dos APLs selecionados; \\
& Promover as Rodadas de Apreciação dos PDPs a nível estadual; \\
& Articular soluções estaduais para as demandas dos APLs selecionados; \\
& Submeter ao GTP APL as demandas que podem ser resolvidas no \\
& âmbito federal; \\
& Acompanhar a implementação das ações do PDP; \\
& Reportar resultados ao GTP APL. \\
\hline Da Secretaria Técnica do GTP & Encaminhar o formulário de PDP ao Núcleo Estadual; \\
APL & Receber e encaminhar os PDPs às instituições do GTP APL; \\
& Promover os Workshops de Integração dos Instrumentos/Ações em \\
& nível federal; \\
& Articular soluções federais para as demandas dos APLs selecionados; \\
& Consolidar e encaminhar a agenda de compromissos no nível federal \\
& aos núcleos estaduais e aos interlocutores do APL; \\
& Disponibilizar o sistema de informação (em construção) para o \\
& encaminhamento dos processos de análise e para o acompanhamento \\
& da implementação das ações dos PDPs \\
\hline Do GTP APL: & Receber os PDPs da Secretaria Técnica; \\
& Analisar as ações do PDP a partir das condições de atendimento dos \\
& instrumentos disponíveis e de suas regras de acesso; \\
& Participar dos Workshops de Integração das Ações; \\
& Participar da construção da agenda de compromisso federal; \\
& Promover os projetos específicos \\
\hline
\end{tabular}

Relevante apontar aqui é que a política de fomento aos APLs prescinde da utilização de vínculos jurídicos mais robustos. Em momento algum o Manual de Apoio aos Arranjos Produtivos Locais ou o Termo de Referência para Política Nacional de Apoio ao Desenvolvimento de Arranjos Produtivos Locais tratam dos mecanismos de formalização dos compromissos assumidos por agentes públicos e privados. Tampouco se cuida da forma pela qual as entidades federais que manifestam intenção de apoiar um APL se articularão para atuar conjuntamente. Nesse sentido, pode-se entender o GTP-APL como um simples mecanismo de organização das demandas oriundas dos Estados, tendo em vista as disponibilidades das instituições federais. Estabelecida, pois, a Agenda de Compromisso, conclui-se que caberá à governança local e aos núcleos estaduais tratar diretamente com a instituição federal em questão a fruição do incentivo cabível. Isto é dizer que não se infere da forma pela qual a política federal de apoio aos APLs foi estruturada que haja um indicativo mínimo de que todo o trabalho realizado no âmbito dos NEs tenha como destino a concretização das medidas ali reclamadas.

De fato, reside aqui uma fragilidade da política federal, já assinalada antes: ela não se funda em instrumentos normativos que assegurem a efetividade das medidas que anuncia. O GTP-APL não só tem o papel de simples canal de comunicão como é 
desprovido de qualquer poder decisório efetivo. Aliás, não há qualquer regra positivada que estabeleça de maneira inequívoca um centro decisório no âmbito federal em relação ao fomento dos APLs. Prevalecem, pois, em princípio, a conveniência e a oportunidade de cada ministério ou entidade da administração indireta.

3.2.2.1 Articulação no mesmo plano federativo e em planos distintos: convênios e consorcios

A principal implicação jurídica da maneira pela qual a política de fomento foi estruturada traduz-se na eleição do convênio de colaboração como o instituto pelo qual os agentes públicos e paraestatais tendem a criar vínculos entre si. Até que as políticas de incentivo aos APLs tenham um caráter refratário à vinculação de seus partícipes e beneficiários em termos mais firmes, e enquanto elas não contem com uma entidade pública dotada de poder decisório que coordene e centralize as ações estatais no âmbito da União e dos Estados, assistir-se-á à celebração de convênios em profusão. O convênio de cooperação é regulado no art. 116 da Lei n. ${ }^{\circ} 8.666 / 93^{230}$ e pode ser conceituado como "um

230 “Art. 116. Aplicam-se as disposições desta Lei, no que couber, aos convênios, acordos, ajustes e outros instrumentos congêneres celebrados por órgãos e entidades da Administração. $\$ 1^{\underline{o}}$ A celebração de convênio, acordo ou ajuste pelos órgãos ou entidades da Administração Pública depende de prévia aprovação de competente plano de trabalho proposto pela organização interessada, o qual deverá conter, no mínimo, as seguintes informações: I - identificação do objeto a ser executado; II - metas a serem atingidas; III - etapas ou fases de execução; IV - plano de aplicação dos recursos financeiros; V-cronograma de desembolso; VI - previsão de início e fim da execução do objeto, bem assim da conclusão das etapas ou fases programadas; VII - se o ajuste compreender obra ou serviço de engenharia, comprovação de que os recursos próprios para complementar a execução do objeto estão devidamente assegurados, salvo se o custo total do empreendimento recair sobre a entidade ou órgão descentralizador. $\$ 2^{\underline{o}}$ Assinado o convênio, a entidade ou órgão repassador dará ciência do mesmo à Assembléia Legislativa ou à Câmara Municipal respectiva. $\S 3^{o}$ As parcelas do convênio serão liberadas em estrita conformidade com o plano de aplicação aprovado, exceto nos casos a seguir, em que as mesmas ficarão retidas até o saneamento das impropriedades ocorrentes: I - quando não tiver havido comprovação da boa e regular aplicação da parcela anteriormente recebida, na forma da legislação aplicável, inclusive mediante procedimentos de fiscalização local, realizados periodicamente pela entidade ou órgão descentralizador dos recursos ou pelo órgão competente do sistema de controle interno da Administração Pública; II - quando verificado desvio de finalidade na aplicação dos recursos, atrasos não justificados no cumprimento das etapas ou fases programadas, práticas atentatórias aos princípios fundamentais de Administração Pública nas contratações e demais atos praticados na execução do convênio, ou o inadimplemento do executor com relação a outras cláusulas conveniais básicas; III - quando o executor deixar de adotar as medidas saneadoras apontadas pelo partícipe repassador dos recursos ou por integrantes do respectivo sistema de controle interno. $\$ 4^{\circ}$ Os saldos de convênio, enquanto não utilizados, serão obrigatoriamente aplicados em cadernetas de poupança de instituição financeira oficial se a previsão de seu uso for igual ou superior a um mês, ou em fundo de aplicação financeira de curto prazo ou operação de mercado aberto lastreada em títulos da dívida pública, quando a utilização dos mesmos verificar-se em prazos menores que um mês. $\S 5^{\underline{o}}$ As receitas financeiras auferidas na forma do parágrafo anterior serão obrigatoriamente computadas a crédito do convênio e aplicadas, exclusivamente, no objeto de sua finalidade, devendo constar de demonstrativo específico que integrará as prestações de contas do ajuste. $6^{-}$Quando da conclusão, denúncia, rescisão ou extinção do convênio, acordo ou ajuste, os saldos financeiros remanescentes, inclusive os provenientes das receitas 
acordo de vontades, em que pelo menos uma das partes integra a Administração Pública, por meio do qual são conjugados esforços ou recursos, visando disciplinar a atuação harmônica e sem intuito lucrativo das partes, para o desempenho de competências administrativas" ${ }^{\prime 231}$. Entende-se, de um modo geral, que, por traduzir a conjunção de objetivos de interesses comuns dos convenentes, não apresenta o sinalagma típico dos contratos, bem como impede a aplicação de sanções recíprocas. Assim, em caso de descumprimento por um dos convenentes, simplesmente se suspende ou se rescinde o ajuste $^{232}$. Por meio de tal mecanismo podem-se operar parcerias entre entidades da mesma esfera federativa ou de esferas diferentes.

O problema reside, em verdade, na eleição do instituto do convênio como mecanismos de coordenação de entidades administrativas no mesmo plano federativo. Isso decorre da ausência de emprego dos instrumentos institucionais baseados diretamente na hieraquia existente entre a chefia da Administração direta e as demais entidades administrativas. Considerando-se que todas as entidades administrativas subordinam-se à chefia única, bastaria um simples Decreto para que se instaurasse um núcleo decisório responsável pela centralização das ações no plano federativo em questão. Assim é que um Ministério (na esfera federal) ou Secretaria (na esfera estadual ou municipal), ou mesmo um colegiado, poderia ser eleito para desempenhar a função de decidir as ações aplicáveis a um determinado APL, subordinando as demais entidades administrativas da pessoa política a tal decisão.

Já no que concerne à articulação interfederativa, o convênio de colaboração tem a vantagem de não demandar maiores formalidades para sua execução, podendo se mostrar bem adequado em algumas situações, principalmente quando envolve um número reduzido de entidades ou ações cuja efetivação não exija um lapso temporal muito extenso. De outro lado, ele não se presta à criação de vínculos mais estáveis e duradouros, vez que apenas instrumentaliza a ação conjunta dos convenentes para um fim específico e determinado, podendo ser dissovido a qualquer momento. Assim é que ele viabiliza ações pontuais entre os entes públicos, mas não viabiliza, por exemplo, a instalação de uma estrutura

obtidas das aplicações financeiras realizadas, serão devolvidos à entidade ou órgão repassador dos recursos, no prazo improrrogável de 30 (trinta) dias do evento, sob pena da imediata instauração de tomada de contas especial do responsável, providenciada pela autoridade competente do órgão ou entidade titular dos recursos."

${ }^{231}$ JUSTEN FILHO, Marçal. Comentários à Lei de Licitações e Contratos Administrativos. São Paulo: Dialética, $13^{\mathrm{a} e d}$., 2009.

${ }^{232}$ DI PIETRO, Maria Sylvia Z. Parcerias na Administração Pública. São Paulo: Atlas, 2008, 6ª ed, p. 230231. 
burocrática voltada à promoção de um APL, tal como uma agência regional de desenvolvimento capaz de congregar bens e serviços em apoio às empresas locais. Investimentos de maior vulto que exijam um gerenciamento compartilhado e duradouro dificilmente são feitos por meio de convênio.

Para esse tipo de situação, em que se pretende estabelecer uma estrutura burocrática permanente e congregar ações de pessoas políticas diferentes por prazo maior, cabe a constituição de um consórcio público.

Regulado pela Lei 11.107/05, o consórcio público é uma pessoa jurídica formada por pessoas políticas que buscam exercer atividades de interesse comum ${ }^{233}$. O consórcio pode resultar da união de Municípios; de um ou mais Municípios com um ou mais Estados; de Estados; da União de um ou mais Estados, podendo, nessa hipótese, contar com a presença de Municípios desse(s) Estado(s) ${ }^{234}$. O consórcio se forma por meio da aprovação da lei que veicula o protocolo de intenções negociado pelos chefes do Executivo das pessoas políticas; esse processo de aprovação é qualificado pela Lei como celebração do contrato de consórcio ${ }^{235}$. O consórcio público pode assumir a forma de pessoa jurídica de direito público, tal qual uma espécie de autarquia interfederativa, ou se revestir da forma de direito privado, tal qual uma associação civil ${ }^{236}$. Em ambos os casos, pode congregar competências originárias dos entes consorciados, podendo receber recursos deles por meio

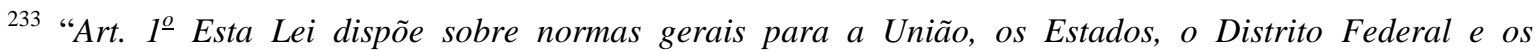
Municípios contratarem consórcios públicos para a realização de objetivos de interesse comum e dá outras providências".

234 “Art. $1^{\circ}(\ldots) \& 2^{\underline{o}}$ A União somente participará de consórcios públicos em que também façam parte todos os Estados em cujos territórios estejam situados os Municípios consorciados" e "Art. $4^{o}(\ldots) \S 1^{o}$ Para os fins do inciso III do caput deste artigo, considera-se como área de atuação do consórcio público, independentemente de figurar a União como consorciada, a que corresponde à soma dos territórios: I-dos Municípios, quando o consórcio público for constituído somente por Municípios ou por um Estado e Municípios com territórios nele contidos; II - dos Estados ou dos Estados e do Distrito Federal, quando o consórcio público for, respectivamente, constituído por mais de 1 (um) Estado ou por 1 (um) ou mais Estados e o Distrito Federal; III - (VETADO); IV - dos Municípios e do Distrito Federal, quando o consórcio for constituído pelo Distrito Federal e os Municípios; e V-(VETADO)"..

235 “Art. 5ㅇ O contrato de consórcio público será celebrado com a ratificação, mediante lei, do protocolo de intenções".

236 “Art. $6^{-}$O consórcio público adquirirá personalidade jurídica: I - de direito público, no caso de constituir associação pública, mediante a vigência das leis de ratificação do protocolo de intenções; II - de direito privado, mediante o atendimento dos requisitos da legislação civil. $\$ 1^{\underline{o}}$ O consórcio público com personalidade jurídica de direito público integra a administração indireta de todos os entes da Federação consorciados. $\S 2^{\circ}$ No caso de se revestir de personalidade jurídica de direito privado, o consórcio público observará as normas de direito público no que concerne à realização de licitação, celebração de contratos, prestação de contas e admissão de pessoal, que será regido pela Consolidação das Leis do Trabalho CLT'.
} 
de contrato de rateio ${ }^{237}$ e contar com quadro próprio de funcionários ${ }^{238}$. Tanto o contrato de consórcio quanto o contrato de rateio podem prever mecanismos de cumprimento das obrigações assumidas pelo ente consorciado face ao consórcio mesmo em caso de retirada deste último ${ }^{239}$.

A principal vantagem desse instituto jurídico, pois, é dar estabilidade institucional para a associação das pessoas políticas tendo em vista um determinado objetivo. Ele induz à assunção de compromissos num regime de cumprimento mais rígido, por prazos mais longos, além de permitir a instalação de uma estrutura burocrática própria e afeta a um fim específico. No âmbito das políticas de promoção dos APLs, o consórcio público se presta principalmente à reunião de Municípios de uma mesma região, conquanto a participação do(s) Estado(s) ${ }^{240}$, e eventualmente também da União, não seja impossível. O consórcio pode congregar os instrumentos que os Municípios usem isoladamente, possibilitando a realização de investimentos conjuntos. Além disso, o consórcio propicia um canal único para as ações estaduais e federais, as quais não precisariam se articular com cada Município em particular para se efetivarem.

\subsubsection{Formas jurídicas dos vínculos entre agentes produtivos e acesso aos instrumentos de fomento}

Se o tópico anterior preocupava-se com os vínculos entre agentes públicos, este aqui trata mais de analisar algumas formas de vínculo dos agentes privados inseridos num APL que impliquem maior acesso aos instrumentos de fomento. Essa preocupação se impõe porque, não obstante as empresas poderem se unir de maneira informal, essa união não é reconhecida do ponto de vista jurídico, deixando de produzir efeitos recíprocos entre as empresas e entre elas e o Estado. A forma pela qual o arranjo se estrutura traz implicações, por exemplo, para suas oportunidades de crédito; assim é que a existência de

\footnotetext{
237 "Art. 8o Os entes consorciados somente entregarão recursos ao consórcio público mediante contrato de rateio."

238 “Art. 4 São cláusulas necessárias do protocolo de intenções as que estabeleçam: (...) IX - o número, as formas de provimento e a remuneração dos empregados públicos, bem como os casos de contratação por tempo determinado para atender a necessidade temporária de excepcional interesse público”.

239 “Art. 11. A retirada do ente da Federação do consórcio público dependerá de ato formal de seu representante na assembléia geral, na forma previamente disciplinada por lei. (...) $§ 2^{-}$A retirada ou a extinção do consórcio público não prejudicará as obrigações já constituídas, inclusive os contratos de programa, cuja extinção dependerá do prévio pagamento das indenizações eventualmente devidas".

${ }^{240}$ Municípios contíguos de Estados diferentes podem formar consórcio com ambos os Estados.
} 
vínculos sedimentados entre as empresas, concretizados em relações que deem indícios de que haja mecanismos de controle recíproco de suas atividades (como em certas associações e cooperativas) atrai mais facilmente a atuação das políticas de fomento.

Não se busca neste tópico indicar mecanismos de formalização da atividade produtiva individual $^{241}$; conquanto isso seja importante no que se refere às políticas de promoção dos APLs - principalmente dos que contam com formas rudimentares de organização da produção $\mathrm{O}$ que se deve encontrar são as potencialidades portadas por algumas formas de organização coletiva da atividade produtiva. Em síntese, afiguram-se três institutos jurídicos capazes de dar formato adequado à ação coletiva cooperativa: os consórcios (de compra e/ou venda, inclusive importação e/ou exportação), cooperativas e associações. Os dois primeiros prestam-se mais a viabilizar algumas ações voltadas especificamente à produção, enquanto que as associações (incluídas nessa espécie os sindicatos) também têm o potencial de funcionar como uma instância de representação política. Para além dessas espécies mencionadas, há duas clássicas formas pelas quais as firmas podem se relacionar e ensejar ações de fomento: a contratualização e a formação de novas empresas.

Neste tópico, expor-se-ão alguns caracteres das figuras acima citadas, não com o propósito de descrever a totalidade do regime a elas aplicável, mas para destacar suas possibilidades de aplicação no âmbito dos APLs.

\subsubsection{Contratualização}

A forma jurídica elementar de vinculação de agentes privados de mercado é o contrato. O seu mecanismo fundamental de operação é expresso no conceito de bilateralidade ou na figura do sinalágma, segundo os quais o interesses recíprocos das partes contratantes reside na obtenção da utilidade que o outro pólo da relação pode disponibilizar em razão da contraprestação a que faz jus. De acordo com a lógica do contrato ordinário, o benefício que uma parte aufere pode depender da diminuição da prestação que lhe cabe realizar e da maximização da prestação que lhe cabe receber. Isto é, a barganha, o comportamento não-cooperativo, está pressuposta no estabelecimento da

\footnotetext{
${ }^{241}$ Os incentivos à formalização do empreendedorismo de micro e pequeno porte estão previstos na Lei Complementar 123/06 (Estatuto Nacional da Microempresa e da Empresa de Pequeno Porte), a qual, em razão da edição da Lei Complementar 128/08, passou a tratar também da figura do microempreendedor individual.
} 
quase totalidade das relações mercadológicas travadas ordinariamente. A lógica da barganha, contudo, tem seus limites, principalmente quando as relações entre os agentes dão-se no longo prazo (o que, por si, faz o negócio em questão se submeter maiores riscos mercadológicos) e envolvem a execução de atividades que são de interesse comum. Como já assinalado em relação às estruturas de subcontratação em cadeias produtivas, e de todo aplicável a situações como o desenvolvimento comum de processos ou produtos, a subsistência de uma conduta de rivalidade entre as partes contratantes produz não um benefício, mas um prejuízo mútuo. Daí o reconhecimento de que, em alguma situações, a descrição da relação entre as partes contratantes exige um outro parâmetro normativo, que não cabe nos estritos limites do atributo da bilateralidade normalmente pressuposta nos contratos ordinários $^{242}$.

Todavia, dificilmente um contrato simples enseja um vínculo tal entre firmas presentes num APL capaz de fazê-las se beneficiar da ação cooperativa. Isto se dá também porque o ordenamento confere às empresas outras opções de formalização de vínculos que comportam incentivos mais robustos. O estabelecimento de uma parceria via contratualização simples tem o atributo de ser um procedimento simples e desprovido de maiores burocracias, bastando a formalização do negócio; mas as vantagens decorrentes da utilização de outras formas intitucionais representativas da ação coletiva das firmas num APL tem aptidão de alcançar resultados importantes e de efeitos econômicos significativos.

\section{$\underline{\text { 3.2.3.2 Criação de empresas }}$}

As firmas partícipes de um APL também podem se fundir ou criar empresas para propósitos específicos. Isso pode ter consequências positivas na medida em que propicie economias de escala ou otimização de custos - a exemplo do que busca qualquer fusão empresarial. Contudo, essa forma de associação interpresarial não é incentivada por si; isto é, a simples fusão de empresas, estejam elas num APL ou não, não atrai a ação das entidades de fomento. Todavia, nada impede que as políticas de incentivo atribuam vantagens à realização de tal negócio, caso se perceba que num determinado Arranjo a redução do número de empresas atuantes num mesmo segmento possa ser benéfica,

\footnotetext{
${ }^{242}$ A teoria dos contratos relacionais tenta dar conta de vínculos obrigacionais complexos e de longo termo caracterizados pela necessidade de regulação da constante interação e negociação das partes. Para uma apresentação da aplicabilidade dessa ideia à regulação de cadeias vericalizadas, em sistemas de produção flexível, ver MACEDO JR. RONALDO P. Contratos Relacionais e Defesa do Consumidor. São Paulo: RT, 2006, $2^{\circ}$ ed..
} 
organizando melhor a divisão do trabalho e propiciando ganhos de escala. Esse trabalho demanda um conhecimento aprofundado do funcionamento das firmas locais, e tem, obviamente, uma boa dose de risco. É muito pouco provável que, partindo a sugestão dessa medida pelo poder público, os empresários de um Arranjo permitam ampla pesquisa sobre o estado e o funcionamento de suas empresas. Todavia, uma vez que o trabalho de convencimento logre êxito, ou caso haja alguma disposição dos empresários nesse sentido, as agências de fomento local devem proporcionar os meios de realização da fusão ou de criação da empresa.

\subsubsection{Consórcios}

O consórcio se presta a formalizar a atuação conjugada de empresas que não estejam interessadas em unir esforços em relação a todos os aspectos da atividade produtiva, formando uma empresa, mas apenas no que concerne a aspectos específicos. $\mathrm{O}$ consórcio possibilita às empresas de menor porte associarem-se em segmentos específicos, compartilhando custos e riscos, bem como somando poder de mercado, tendo em vista objetivos comuns (compra, venda, desenvolvimento de processos ou produtos, produção), ao passo que, nos demais segmentos, podem manter autonomia mercadológica. Quanto maior o número de consorciados, maior a pulverização dos encargos decorrentes da atividade em questão; mas, por outro lado, também maior é a complexidade de equalização de interesses ${ }^{243}$.

Segundo o art. 278 da Lei n..$^{\circ}$ 6.404/76, as "companhias e quaisquer outras sociedades, sob o mesmo controle ou não, podem constituir consórcio para executar determinado empreendimento". Supõe-se, pois, que escopo do consórcio seja mais restrito que o objeto social das pessoas que o criam. Ele não te personalidade jurídica, de forma que as consorciadas se obrigam pelo quanto assumido por elas no contrato de constituição $^{244}$.

${ }^{243}$ Para uma discussão sobre vantagens e desvantagens da adoção de consórcios por MPMEs na atividade exportadora, mas de todo aplicável aos demais objetivos possíveis de um consorcio, ver LIMA, G. B., NEVES, M.F \& OLIVEIRA, L. Consórcio de Exportação como Alternativa às Pequenas e Médias Empresas: Um caso na Cadeia Têxtil - Anais do XL Congresso Brasileiro de Economia e Sociologia Rural SOBER, "Equidade e Eficiência na Agricultura Brasileira", Universidade de Passo Fundo (UPF), Passo Fundo - Rio Grande do Sul, 28 a 31 de julho de 2002.

244 "Art. 279. O consórcio será constituído mediante contrato aprovado pelo órgão da sociedade competente para autorizar a alienação de bens do ativo não circulante, do qual constarão: I - a designação do consórcio 
A Lei Complementar n. ${ }^{\circ}$ 123/07 parece eleger o consórcio como uma forma preferencial de conjugação de microempresas e empresas de pequeno porte. $\mathrm{O}$ art. 56 do diploma prevê que elas podem constituir consórcios de compra e venda de bens e serviços, para o mercado nacional e internacional. Contudo, o texto legal dá a entender que a constituição desse tipo de consórcio se submeterá ao regramento que vier estabelecido em Decreto presidencial $^{245}$. Até o momento, esse regulamento não foi editado; isso não significa, entretanto, que as microempresas e empresas de pequeno porte estejam impedidas de celebrar consórcios - o que já é de todo autorizado pela Lei 6.404/76. Cabe interpretar o art. 56, portanto, não como um autorizador da formação de consórcios, mas como um anúncio de que se criará um programa de incentivos destinado a tal forma de atuação das microempresas e empresas de pequeno porte. Nesse sentido, é de se considerar que o $\S 2^{\circ}$ do art. 56, tão-somente enuncia os objetivos que a política de fomento ao consorciamento deve buscar: aumento de competitividade, inserção em novos mercados internos e externos por meio de ganhos de escala, redução de custos, gestão estratégica, maior capacitação, acesso a crédito e a novas tecnologias. Isto porque a Lei não pode ter o propósito de estabelecer a racionalidade econômica subjacente à celebração do consórcio tal como parece decorrer da redação do dispositivo - pois isso é um dado da realidade e não decorre de prescrição normativa.

Não existe um mecanismo de incentivo à formação de consórcios que decorra imediatamente da Lei, isto é, o simples fato de empresas, inseridas ou não num APL, valerem-se de consórcios, não implica a fruição de vantagem qualquer. Contudo, as entidades de fomento podem dar incentivos especiais a empresas que se consorciem para algum fim, eis que o atendimento conjunto das empresas é medida que proporciona economia de meios ao poder público.

se houver; II - o empreendimento que constitua o objeto do consórcio; III - a duração, endereço e foro; IV a definição das obrigações e responsabilidade de cada sociedade consorciada, e das prestações específicas; $V$ - normas sobre recebimento de receitas e partilha de resultados; VI - normas sobre administração do consórcio, contabilização, representação das sociedades consorciadas e taxa de administração, se houver; VII - forma de deliberação sobre assuntos de interesse comum, com o número de votos que cabe a cada consorciado; VIII - contribuição de cada consorciado para as despesas comuns, se houver. Parágrafo único. $O$ contrato de consórcio e suas alterações serão arquivados no registro do comércio do lugar da sua sede, devendo a certidão do arquivamento ser publicada."

245 “Art. 56. As microempresas ou as empresas de pequeno porte optantes pelo Simples Nacional poderão realizar negócios de compra e venda, de bens e serviços, para os mercados nacional e internacional, por meio de consórcio, por prazo indeterminado, nos termos e condições estabelecidos pelo Poder Executivo federal. $\S 1^{\underline{o}} O$ consórcio de que trata o caput deste artigo será composto exclusivamente por microempresas e empresas de pequeno porte optantes pelo Simples Nacional. $\S 2^{\underline{o}}$ O consórcio referido no caput deste artigo destinar-se-á ao aumento de competitividade e a sua inserção em novos mercados internos e externos, por meio de ganhos de escala, redução de custos, gestão estratégica, maior capacitação, acesso a crédito e a novas tecnologias." 
As políticas de fomento direcionadas a consórcios parecem ser especialmente eficazes em matéria de prestação de serviços de interesse comum das empresas de um APL. Isto porque, ao contrário da criação de associações ou cooperativas, não há a necessidade de criação de uma estrutura própria e permanente; há simples união de empresas para a repartição de encargos.Nesse sentido é de se citar programas como os majeados pela APEX-Brasil, que incentiva a formação de consórcios de exportação, subvencionando atividades de promoção comercial de alguns produtos. Não há incentivo diretamente às empresas, mas ao consórcio por elas formados, os quais se destinam a reunir as empresas de um determinado setor para compartilhamento de despesas de ações que as beneficiem conjuntamente.

\subsubsection{Cooperativas}

A cooperativa é uma sociedade de natureza civil de pessoas que se associam para se obrigar reciprocamente a contribuir com bens ou serviços, para o exercício de uma atividade econômica de proveito comum dos cooperados, sem objetivo de lucro (art. $4^{\mathrm{o}}$ da Lei 5.764/71).

A adesão às cooperativas é voluntária, e elas podem contar com um número ilimitado de associados (inc. art. $4^{\circ}$, I). Dado que não têm caráter lucrativo, o eventual excedente das cooperativas não pode ser distribuído. Em princípio não há limitações ao campo de atuação das cooperativas, eis que o art. $5^{\circ}$ estabele que "poderão adotar por objeto qualquer gênero de serviço, operação ou atividade".

De todo modo, para fins didáticos, podemos categorizá-las em cooperativas de consumo, de produção ou de crédito. A principal vantagem mercadológica das cooperativas reside na não incidência dos tributos sobre a renda em razão de operações entre a entidade e o associado (imposto de renda e proventos) ou o lucro (contribuição social sobre o lucro líquido), já que, conceitualmente, não há realização de lucro em razão da obrigatoriedade da aplicação do resultado positivo no Fundo de Assistência Técnica, Educacional e Social da entidade ${ }^{246}$.

\footnotetext{
246 "Art. 87. Os resultados das operações das cooperativas com não associados, mencionados nos artigos 85 e 86, serão levados à conta do "Fundo de Assistência Técnica, Educacional e Social" e serão contabilizados em separado, de molde a permitir cálculo para incidência de tributos".
} 
Cooperativas singulares são aquelas constituídas pelo número mínimo de 20 (vinte) pessoas físicas, sendo excepcionalmente permitida a admissão de pessoas jurídicas que tenham por objeto as mesmas ou correlatas atividades econômicas das pessoas físicas ou, ainda, aquelas sem fins lucrativos (art. $6^{\circ}$ ). Este tipo de cooperativa se caracteriza pela prestação direta de serviços aos seus associados (art. $7^{\circ}$ ).

Já as cooperativas centrais ou federações de cooperativas são as "constituídas de, no mínimo, 3 (três) singulares, podendo, excepcionalmente, admitir associados individuais" (inc. II). O propósito das centrais e federações é "organizar, em comum e em maior escala, os serviços econômicos e assistenciais de interesse das filiadas, integrando e orientando suas atividades, bem como facilitando a utilização recíproca dos serviços", sendo que "para a prestação de serviços de interesse comum, é permitida a constituição de cooperativas centrais, às quais se associem outras cooperativas de objetivo e finalidades diversas" (art. $\left.8^{\circ}\right)$.

As confederações de cooperativas são aquelas “constituídas, pelo menos, de 3 (três) federações de cooperativas ou cooperativas centrais, da mesma ou de diferentes modalidades" (inc. III), tendo elas por finalidade "orientar e coordenar as atividades das filiadas, nos casos em que o vulto dos empreendimentos transcender o âmbito de capacidade ou conveniência de atuação das centrais e federações" (art. $9^{\circ}$ ).

As cooperativas, pois, têm um campo de aplicação que vai desde a organização da força de trabalho para propósitos mercantis, funcionando como mecanismo de formalização da atividades rudimentares exercidas por autônomos, até mesmo à construção de esquemas sofisticados de distribuição e comercialização. No âmbito dos APLs, podem ser usadas para os mesmos fins a que se destinam os consórcios citados acima: compra de insumos comuns, venda de produtos, realização de etapas do processo produtivo de que aproveitem algumas empresas. A diferença é que permitem formalizar estruturas de produção mais robustas, o que normamente não se faz mediante simples consórcios. Além disso, elas podem fornecer crédito aos associados.

As cooperativas de crédito são reguladas pela Lei Complementar n. ${ }^{\circ} 130$ e são consideradas instituições financeiras (art. $1^{\circ}$ ), submentendo-se, pois, à regulação do CMN e do Banco Central (art. $\left.1^{\circ}, \S^{\circ}\right)$. A função precípua delas é "prover, por meio da mutualidade, a prestação de serviços financeiros a seus associados, sendo-lhes assegurado o acesso aos instrumentos do mercado financeiro". A captação de recursose a concessão de créditos e garantias são restritas aos cooperados, podendo as cooperativas 
realizar tais operações "com outras instituições financeiras", bem como captar recursos de "pessoas jurídicas, em caráter eventual, a taxas favorecidas ou isentos de remuneração". Apesar de o Poder Público não restar totalmente impedido de se valer dessa forma jurídica para criar instituições de fomento financeiro - pois o art. $4^{\circ}$, parágrafo único, admite que as empresas estatais não dependentes possam figurar como cooperadas ${ }^{247}$, é difícil imaginar uma empresa estatal submeter-se às limitações impostas pela condição de cooperada e escolher essa via de acesso ao crédito em vez de se valer de outras formas de financiamento.

A principal vantagem do emprego das cooperativas de crédito reside na tendência da entidade a cobrar taxas de juros menores que as das demais instituições financeiras, dado que ela não tem intuito lucrativo e, em princípio, por ter maior conhecimento das atividades do cooperado (diminuição da assimetria de informações vis a vis a verificada no sistema bancário comum), pode avaliar melhor o risco de crédito, eventualmente considerando-o baixo e, assim, ensejador de taxas de juros mais módicas.

Cabe assinalar também o potencial emancipador do funcionamento desse tipo de instituição porquanto ela tem o condão de superar a barreira do crédito que se coloca em face das MPMEs. Quando se verifica o fomento ao fenômeno cooperativo, baseando-os nas relações de proximidade e confiança entre os agentes cooperados, cria-se um ambiente em que a concessão do crédito é facilitada ${ }^{248}$.

As cooperativas também podem ser utilizadas para a constituição dos fundos de aval. Nesse caso, o cooperado contribui para a formação do capital do fundo garantidor tal como referido no tópico 2.2.4. Cabe mencionar, ademais, que a instituição financeira pode levar em consideração, em sua análise de risco de inadimplência, a pré-seleção realizada pela própria cooperativa, o que tende a diminuir as taxas de juros.

\footnotetext{
247 “Art. $4^{o}$ (...). Parágrafo único. Não serão admitidas no quadro social da sociedade cooperativa de crédito pessoas jurídicas que possam exercer concorrência com a própria sociedade cooperativa, nem a União, os Estados, o Distrito Federal e os Municípios bem como suas respectivas autarquias, fundações e empresas estatais dependentes."

248 Ricardo ABRAMOVAY e Rodrigo Gravina P. JUNQUEIRA relatam o caso do sistema Cresol, cooperativa central de crédito rural que logrou, mediante a estruturação de grupos comunitários, constituir um sistema de gestão e controle baseado em redes sociais, amparado sobretudo em relações de confiança. A cooperativa tem desenvolvido programas de financiamento capazes de atender às necessidades dos associados de forma mais eficiente que os programas governamentais, o que ajuda a explicar o crescimento signifiativo do volume de crédito com que opera. Ver "A sustentabilidade das finanças solidárias". Revista de Administração, São Paulo, v. 40, n. 1, 2005, p. 19-33.
} 


\subsubsection{Associações}

Associações são pessoas jurídicas de direito privado formadas pela união de pessoas que se organizam para fins não econômicos ${ }^{249}$, vale dizer, fins não distributivos (a entidade pode gerar lucro, mas não pode distribuí-los entre os associados). Dentro desses limites da finalidade da entidade, qualquer objeto social é admissível para as associações, sendo certo que a atuaçaõ dos associados pode proporcionar benefícios economicamente mensuráveis, tal como a prestação de serviços de interesse comum.

A associação é a forma por excelência das instituições destinadas a representar intereses de classe, e, nesse sentido, a atuação delas no âmbito dos APLs é muito importante, servindo como canal das reivindicações dos agentes locais. Mas no que se refere às ações em prol dos associados, pode-se cogitar em toda forma de prestação de serviços - assistência técnica, treinamento, oficinas, promoção de ações comerciais, e mesmo a constituição de garantias creditíticias, tal como indicado no tópico 2.2.4.

249 "Art. 53. Constituem-se as associações pela união de pessoas que se organizem para fins não econômicos.Parágrafo único. Não há, entre os associados, direitos e obrigações recíprocos" 


\section{CAPÍTULO 4}

\section{ALGUNS CASOS DE PROMOÇÃO DE APLS}

Este capítulo busca expor alguns casos de aplicação das políticas promoção dos APLs. Procura-se tratar aqui de situações que congregem um número significativo de instituições e de emprego de instrumentos de fomento de modo a aclarar as possibilidades da intervenção estatal nos APLs. O conteúdo eminentemente descritivo deste capítulo se dá não só por uma questão de afinidade com o método de abordagem do tema nesta dissertação, mas também porque os estudos de casos sobre APLs ainda carecem de maior robustez, principalmente no que toca aos resultados econômicos da ação estatal.

Tem-se, aqui, alguns relatos. O primeiro deles, trata de uma experiência em Quixeramobim, no semi-árido cearense, onde a articulação das instituições de fomento resultou na evolução da rudimentar estrutura agrícola local, possibilitando a inserção dos agricultores familiares, outrora voltados à subsistência, no mercado regional. O segundo relato, sobre a indústria coureiro-calçadista no Vale dos Sinos, interior do Rio Grande do Sul, dá conta de um Arranjo mais estruturado, no qual se verifica a presença longeva de uma gama considerável de entidades de apoio à produção local. O terceiro relato, sobre a produção confectionista de Campina Grande, demonstra como as práticas cooperativas e as ações das entidades de fomento devem se reiventar na medida em que o setor do APL passa por transformações.

\subsection{APL Pingo D’ÁguA ${ }^{250}$}

Este Arranjo Produtivo Local é exemplo de criação induzida da cooperação por meio de política pública articulada por diversas entidades, em todas as esferas da Federação. Ele é composto atualmente por um grupo de 27 agricultores familiares dedicados à fruticultura, que originariamente tinham seu sustento na pecuária de pequena escala, e distribuídos por oito comunidades no Município de Quixeramobim, no sertão

\footnotetext{
${ }^{250}$ Baseado em AMARAL FILHO, Jair do "Pingo D'Água: um arranjo inovativo no semi-árido do Ceará" em LASTRES, Helena \& CASSIOLATO, José E. Estratégias para o Desenvolvimento: um enfoque sobre Arranjos Produtivos Locais do Norte, Nordeste e Centro-Oeste Brasileiros. Rio de Janeiro, E-papers, 2006 e JACOB, Carlos Augusto Antonelli; BRANDÃO, Júlia B. \& GODOY, Melissa Giacometti. Projeto Pingo D'Água - Quixeramobim Ceará São Paulo: FGV, 2006. Disponível em http://www.eaesp.fgvsp.br/subportais/interna/Conexao_Local/08_CL_2006_PingoDagua.pdf.
} 
cearense. O seu nome alude a uma chacota relacionada ao método de irrigação proposto para a área, consistente no gotejamento de água obtida em terras de aluvião; antes das ações em prol do APL, a comunidade considerava a água inaproveitável. Apesar da sua pequena relevância para a economia nacional ou mesmo estadual, as transformações verificadas no APL Pingo D’Água fizeram-no modelo que passou a ser replicado em outras localidades $^{251}$.

As principais dificuldades enfrentadas pelos produtores locais para o ingresso na atividade agrícola eram a inexistência de infra-estrutura de irrigação e o acesso ao crédito. Além disso, a falta de informação e treinamento contribuía decisivamente para a estagnação da atividade desses produtores.

A partir de meados dos anos 1990, a união entre a prefeitura local e a Universidade Estadual do Ceará (UECE), em convênio com a Universidade de d'Anger (França), logrou desenvolver um sistema de irrigação inovador, que passou a aproveitar água oriunda das terras de aluvião, até então pouco aproveitadas e tidas como de uso inviável. Parte da infraestrutura física de irrigação foi elaborada no próprio Município, em metalúrgicas de pequeno porte. O custo com a instalação dos sistemas de irrigação nas propriedades particulares não foi arcado pelo poder público, mas a prefeitura estruturou um fundo de aval que garantia até $50 \%$ do valor mutuado para que os agricultores pudessem ter acesso a crédito bancário - o que foi feito principalmente pela linha do PRONAF operada pelo BNB. A prefeitura também construiu estufas para as mudas e chegou a doar sementes, fertilizantes e defensivos aos agricultores locais. A assistência técnica aos agricultores tem sido realizada pela Associação Municipal de Agrônomos, que conta com treinamentos da Secretaria de Agricultura estadual e do Sebrae. As ações cooperativas entre os produtores se dão no compartilhamento do cultivo de mudas e na venda conjunto da produção, além da participação de feiras e eventos e de divulgação. Importante citar que, na opinião dos agricultores, as ações de assistência técnica e treinamento são as de maior importância para o sucesso de suas atividades.

Em síntese, as ações no APL resultaram no surgimento do cultivo de 38 hectares, que garantam de duas a três safras por ano, e beneficiaram não só as famílias produtoras (que passaram a contar com uma renda significativa se comparada com a situação anterior)

\footnotetext{
${ }^{251}$ A experiência resultou na conquista de prêmios em concursos de programas de inovação promovidos pela Fundação Getúlio Vargas de São Paulo (Programa Gestão Pública e Cidadania), Fundação Banco do Brasil (Prêmio Tecnologia) Sebrae (Prêmio Empreendedor) e Caixa Econômica Federal,
} 
como também o mercado de mão-de-obra local, que experimentou um significativo aquecimento depois que a agricultura deixou de ser simples cultura subsistência e passou a produzir um excedente comercializável.

As ações de fomento à produção local não foram arquitetadas simultaneamente, mas foram sendo conjugadas à medida que se verificou a viabilidade da instalação da friticultura na região em razão do método de irrigação. Atualmente, pode-se dizer que há um programa global de fomento mais estruturado; e, como dito, inspirador de outros projetos no Estado do Ceará. O caso do APL Pingo D’Água ilustra o potencial transformador das ações nojugadas de fomento, mesmo as de menor magnitude.

\subsection{APL COUREIRO-CALÇADISTA DO VALE DOS SINOS ${ }^{252}$}

O interesse no APL do Vale dos Sinos reside na presença de uma quantidade significativa tanto de agentes de mercado que compõem uma cadeia produtiva completa bem como de entidades públicas e privadas ligadas à produção local que possuem ações em comum. Isso permite a conjugação de vários instrumentos de fomento e, como se verá, parece repercutir positivamente na atividade econômica da região.

A região do Vale dos Sinos reúne por volta de 500 empresas calçadistas (a maioria delas de pequeno porte), em torno das quais se estrutura um grande quantidade de firmas relacionadas ao setor: cortumes, prestadores de serviços (inclusive tradings), fabricantes de borrachas, plásticos, máquinas e equipamentos. Num raio de $50 \mathrm{~km}$ (abrangendo cerca de 35 municípios), concentra as principais fabricantes de calçados do Brasil e por volta de $80 \%$ dos fabricantes de bens de capital do setor e $60 \%$ dos fornecedores de outros insumos da indústria calçadista. Considera-se a maior aglomeração produtiva da calçados do mundo, tendo se consolidado nessa condição, principalmente em decorrência do crescimento das exportações entre as décadas de 1960 e 1980. Recentemente, parte das empresas exportadoras tem tentado superar o padrão de negócios dominante, segundo o qual as firmas locais submetem-se às decisões dos agentes de exportação ou dos representantes dos importadores estrangeiros sobre o design e marketing de seus produtos, e dominar os próprios canais de comercialização bem como as marcas e desenhos.

\footnotetext{
${ }^{252}$ Este item é baseado em LEMOS, C., ALBAGLI, S. \& SZAPIRO, M. "Promoção de arranjos produtivos locais: iniciativas em nível federal". Nota Técnica RedeSist, Rio de Janeiro, 2004. Disponível em www.sinal.redesist.ie.ufrj.br.
} 
A região conta com uma estrutura expressiva de entidades de classe que promovem ações importantes:

(i) Associação Brasileira das Indústrias de Calçados (ABICALÇADOS), que é sediada na região (em Novo Hamburgo). Sua atuação principal se dá em torno da imagem do calçado brasileiro no mercado internacional, bem como na superação de intermediários (agentes de exportação e atacadistas importadores) entre os varejistas estrangeiros e as firmas locais.

(ii) Associação Comercial, Industrial e de Serviços de Novo Hamburgo, Campo Bom e Estância Velha (ACI-NH/CB/EV): conta com cerca de 1200 associados e congrega firmas que atuam em toda a cadeia do couro (curtimento, peles semi-acabadas, peles acabadas, e beneficiamento) e derivados. Suas ações principais são a prestação de serviços às empresas, dentre os quais a promoção da Feira Nacional do Calçado.

(iii) Associação Brasileira das Indústrias de Máquinas e Equipamentos para Setores do Couro, Calçados e Afins (ABRAMEQ): também situada em Novo Haburgo, congrega predominantemente micro e pequenas empresas, a maioria do próprio APL. Recebe apoio da APEX para promover a cultura exportadora e criar uma marca brasileira para as máquinas exportadas. Prospecta tendências da moda calçadista em lojas européias e junto ao Senai, o que favorece a adequação das máquinas e equipamentos às demandas do mercado.

(iv) Associação Brasileira de Empresas de Componentes para Couro, Calçados e Artefatos (ASSINTECAL): reúne 190 associados, responsáveis por 80\% da produção de componentes para couro, calçados e artefatos; a grande maioria é de micro e pequenas empresas. Possui grupos setoriais que atuam nos segmentos específicos dos produtos de coutro (embalagens, acessórios, saltos e solados, palmilhas, produtos químicos para couro, dentre outros) Com apoio da APEX, organizou três consórcios de exportação, com 15 empresas cada. A entidade conta com recursos do Fundo Verde e Amarelo do MCT.

(v) Centro Tecnológico do Couro, Calçados e Afins (CTCCA): fundado em 1972, o CTCCA visa difundir tecnologias através de pesquisas, prestação de serviços (como adequação às normas $\mathrm{ABNT}$ ) e informação ao setor calçadista. Possui certificações nacionais e internacionais e é habilitado a fazer centenas de testes. Além disso, é rsponsável pela publicação de uma revista de referencia de informações técnicas sobre o setor coureiro-calçadista.O CTCCA possui parcerias com a UDESC (Universidade do 
Estado de Santa Catarina), a UFRGS (Universidade Federal do Rio Grande do Sul), e o CEFET/RS (Centro Federal de Educação Tecnológica de Pelotas).

(vi) Associação das Indústrias de Curtumes do RS (AICSUL): congrega 70 empresas produtoras de couro do Estado, onde se concentra $30 \%$ da produção nacional. Funciona como um canal dos pleitos do setor, além elaborar estatísticas e divulgar informações sobre a indústria.

(vii) Associação de Desenvolvimento Tecnológico do Vale - VALETEC, por sua vez, reúne prefeituras da região, a ACI-NH/CB/EV, a Associação Pró-Ensino Superior em Novo Hamburgo, instituições de ensino e a agência de fomento estadual. A mais nova iniciativa da entidade é a instalação de um parque tecnológico.

Além disso, o Senai possui duas unidades na região. O Centro Tecnológico do Couro/SENAI CTC, o qual funciona em Estância Velha como um centro de desenvolvimento de tecnologia para a área de processamento de couro e reúne um curtume-escola, oficinas, laboratórios, sistema depurador de efluentes industriais, núcleo de informação tecnológica, salas de aula e auditório. O Centro possui parcerias com empresas, universidades, órgãos governamentais, centros de pesquisa e instituições de fomento, além de oferecer serviços às indústrias como pesquisa aplicada, treinamento e assistência técnica. Já o Centro Tecnológico do Calçado/SENAI (CETECA), localizado em Novo Hamburgo, possuía como missão principal a formação de mão-de-obra para o setor, mas desde a década de 1990 passou a operar também como um centro de tecnologia. Além disso, o SEBRAE de Novo Hamburgo oferece apoio a empresas e instituições do APL do Vale. Sua importância para os ateliês de costura é destacada.

A somar-se a tais instituições e seus programas, o governo federal atua por intermédio do MDIC, da APEX e da FINEP.

A APEX, além do apoio a consórcios exportadores já mencionado, possui parcerias com a Assintecal relativas a apoio comercial e em PSI $^{253}$ visando a exportação de componentes, máquinas e calçados. A Agência arcou com $47 \%$ de um custo total de R $\$ 9,7$ milhões. A Abicalçados também participa de um PSI em que a APEX subvencionou 28\% do valor total aproximado de $\mathrm{R}$ \$22,3 milhões, oportunizando a realização das empresas em feiras internacionais, o que foi considerado decisivo no incremento das exportações para mercados até então incipientes.

${ }^{253}$ Sobre ações de apoio comercial e Programas Setoriais Integrados, vide tópico 2.2.9 
No âmbito do MDIC, foi instalado um Fórum de Competitividade para a cadeia de Couro e Calçados, instância oficial pela qual empresários de todos os segmentos podem apresentar suas demandas ao governo de modo permanente. As principais atividades do Fórum se deram em torno de três temas principais (Inovação e Desenvolvimento Tecnológico; Inserção Externa e Modernização Industrial), cada qual tratado no âmbito de um grupo de trabalho composto por entidades do setor.

Outra importante iniciativa foi protagonizada pela FINEP, com recursos do Fundo Verde e Amarelo, por intermédio do Programa de Apoio à Inovação em Arranjos Produtivos Locais. No APL de Couro e Calçados do Vale do Sinos há dois projetos vinculados a tal fundo: um é o"Capacitação Ambiental para redução e aproveitamento de resíduos sólidos industriais no Arranjo Produtivo de Couro e Calçados/RS”, executado por uma gama de instituiões (Associação Comercial Industrial e de Serviços de Novo Hamburgo e Campo Bom, FEEVALE, CTC- SENAI, Serviço Nacional de Tecnologias Limpas e CTCCA), destinado a incrementar a gestão ambiental e introduzir as melhores práticas de gestão e destinação final de resíduos, bem como pré-qualficar as firmas exportadoras à obtenção da certificação ISO 14000. A FINEP subvenciona R \$ 115 mil de um total de R\$317 mil do projeto. O outro projeto é o "Programa de posicionamento competitivo do segmento de componentes para couro, calçados e acessórios”, contratado em dezembro de 2002 por intermédio da Assintecal e executado por ela e pelo Centro Tecnológico do Calçado SENAI, IBQP-PR - Instituto Brasileiro da Qualidade e Produtividade no Paraná e CTCCA. A finalidade desse programa é sistematiza e organizar as informações relativas ao segmento dos componentes, elaborando um mapeamento das importações, tendo em vista substituí-la. De um valor total orçado em $\mathrm{R}$ \$ 1,2 milhão, a FINEP arcaria com R $\$ 530$ mil.

A Secretaria de Desenvolvimento e dos Assuntos Internacionais do Rio Grande do Sul (Sedai), em setembro de 2001, subvencionou a criação de um centro de design no Valo dos Sinos, voltado principalmente à demanda das empresas de menor porte que não têm condições de arcar com o custo de internalização dessa atividade em seu processo produtivo de modo permanente.

Apesar do reconhecimento do papel decisivo de todas as iniciativas descritas, há um diagnóstico de que o APL do Vale dos Sinos requer ainda a adoção de outras medidas de política pública aptas a enfrentar alguns problemas que podem comprometer a competitividade das firmas ali instaladas: a baixa qualificação da mão-de-obra, agravada 
pela migração de técnicos locais para a China; a pouca cooperação horizontal, fator que pode ser inibidor do potencial exportador das empresas; a pouca representatividade das pequenas empresas nas entidades de classe, as quais, na maioria das situações, tendem a defender predominantemente o interesse das empresas líderes. Aliás, a pequena oferta de incentivos a empresas de menor porte (acesso ao crédito e à capacitação inovativa e tecnológica) é considerada um ponto especialmente problemático do APL.

\subsection{APL De CAMPina Grande ${ }^{254}$}

O APL de confecções de Campina Grande/PB é um exemplo de como as políticas de fomento podem e devem se adaptar às transformações dos mercados fomentados. Quando do florescimento da atividade confecionista no município, a política de fomento se resumia às ações de capacitação empresarial e de promoção do comércio local. Contudo, uma forte crise que abalou o setor local, aliada à presença de um centro de pesquisa (EMBRAPA) que logrou criar um produto portador de vantagens competitivas consideráveis (o algodão colorido), incentivou os atores locais e mudar o enfoque das políticas de fomento, agregando instrumentos mais ousados, tendo em vista o mercado internacional e a expansão das atividades.

Seu marco inicial pode ser considerado o ano de 1980, quando onze costureiras autônomas se reuniram para buscar apoio das instituições governamentais para evoluir da produção caseira para uma organização empresarial. Contaram com o apoio do SEBRAE local, que providenciou treinamento para o grupo no SENAI do Rio Grande do Norte. Um ano depois, já tendo concluído os cursos de capacitação, o grupo criou a Associação de Confeccionistas e, posteriormente, o Sindicato da Indústria do Vestuário da Paraíba (Sindvest), integrante da Federação das Indústrias da Paraíba (Fiep).

A partir de 1984, com o apoio do governo estadual, iniciou-se a construção do Centro Comercial Luiza Motta, concluída em 1990. O SEBRAE-PB geriu o

\footnotetext{
${ }^{254}$ Baseado em MOUTINHO, Lúcia M. G \& CAMPOS, Renato. "A Co-Evolução de Empresas e Instituições em Arranjos Produtivos Locais: Políticas Públicas e Sustentabilidade". Revista Econômica do Nordeste, Fortaleza, v. 38, n² 2, abr-jun. 2007, pp 244-258,; MOUTINHO, Lúcia M. G. \& CAVALCNTI FILHO, Paulo F. "Inovatividade e cooperação no arranjo produtivo local de confecções em Campina Grande-PB" em LASTRES, Helena \& CASSIOLATO, José E. Estratégias para o Desenvolvimento: um enfoque sobre Arranjos Produtivos Locais do Norte, Nordeste e Centro-Oeste Brasileiros. op. cit., pp. 175-192 e em MOUTINHO, Lúcia M \& CAVAlCANTI FILHO, Paulo. F. Proposição de Políticas para Arranjos e Sistemas Produtivos e Inovativos Locais ASPILs: O Arranjo Produtivo de Confecções de Campina Grande/PB. Relatório Final. Disponível em www.redesist.ie.ufrj.br/.../Panel\%2007\%20\%20Paulo\%20Cavalcanti\%20and\%20Lucia\%20Moutinho.pdf.
} 
empreendimento entre 1991 e 1999, sendo que, em 1992, havia 142 lojas de confecção nele instaladas. Rapidamente o lugar passou a ser destino de caravanas varejistas de todo o Nordeste. De 1991 a 1996, deu-se o auge do APL, tendo-se sido verificado o aumento do porte das empresas e grande diversificação de produtos. De 1997 a 2003, deu-se uma retração no Arranjo, com a perda de mais de 40 empresas, fenômeno esse creditado à concorrência com produtos vindos da China e do sudeste brasileiro, sendo que, das firmas existentes em 1990, apenas $25 \%$ sobrevivem até hoje.

A reação à crise começou concomitantemente com a sua instalação, em 1997. Primeiramente, algumas empresas criaram um consórcio visando maior poder de barganha mediante a compra coletiva de matéria-prima e a concessão de aval mútuo em financiamentos. Posteriormente, em 2000, com as oportunidades que o desenvolvimento do algodão naturalmente colorido pela EMBRAPA parecia propiciar, foi formado um consórcio de exportação, o "Consórcio Natural Fashion", reunindo dez empresas de confecções locais, lançado na Fenit com o apoio da Associação Brasileira de Vestuário (Abravest), do Sistema S e da APEX.

O principal propósito do Consórcio foi assegurar o pioneirismo na comercialização do produto, que ainda estava se consolidando. Visando obter prioridade na produção do fio, a prefeitura de Campina Grande e o governo estadual através da Cinep, em parceria com as empresas representadas pela Federação das 'Indústrias da Paraíba (Fiep), compraram todas as sementes e plumas disponíveis na Embrapa. A estratégia do Consórcio também contou com a elaboração de uma linha de produtos comum, o estabelecimento de cotas de produção para cada empresa conforme sua capacidade produtiva e percentual de participação no consórcio. O atrativo principal do produto é o fato de ser produzido no sertão da Paraíba de forma sustentável, sem irrigação nem uso de defensivos - o que atende à demanda de produtos ecologicamente corretos, tendo boa acolhida no mercado europeu.

Graças aos bons resultados do consórcio, em 2003 foi criada a Coopnatural, tendo em vista o atendimento logístico e a comercialização do algodão colorido (compra e venda do algodão, corte e distribuição do tecido para os confeccionistas, distribuição dos produtos para as lojas, algumas delas clientes habituais). No ramo da confecção, a cooperativa é uma novidade sgnificativa, face à predominância das práticas de subcontratação. A indústria calçadista da cidade foi atraída pela Coopnatural, fazendo uso de adornos de tecido de algodão colorido em seus produtos. 
No processo de reorientação das atividades do APL tendo em vista a exploração do diferencial competitivo proporcionado pelo algodão colorido é de se destacar a atuação das intituições de fomento na consolidação da produção da matéria-prima principal. Entre 2000 e 2004, a EMBRAPA, a Empresa de Assistência Técnica e Extensão Rural da Paraíba e a Agência Municipal de Desenvolvimento da prefeitura de Campina Grande concederam apoio técnico gerencial e capacitação profissional para agricultores no que toca à distribuição de sementes, plantio, coleta e armazenamento do algodão colorido.

Atualmente, o Arranjo conta com trinta micro e pequenas empresas de confecções, sendo que vinte e seis delas se associam numa cooperativa de que participam os agricultores produtores de plumas de algodão colorido, uma tecelagem manual de fios deste algodão especial, dez cooperativas produtoras de adereços fornecedoras das confecções e uma grande empresa têxtil que tem poucas relações com as demais. Além disso, há em torno de 120 costureiras autônomas informais.

Em relação às instituições de apoio aos APLs, é de se citar, no que concerne ao treinamento empresarial e da mão-de-obra local, a Companhia de Desenvolvimento da Paraíba (Cinep), o Sistema S e a Secretaria Municipal da Indústria e Comércio de Campina Grande. Além disso, Campina Grande conta com quatro universidades (uma particular, uma estadual, uma federal e a Universidade Corporativada Fiep)e com um Centro de Moda. A unidade do SENAI instalou o Laboratório do Vestuário (Labvest).

Há diversas entidades de classe que cuidam da difusão de informações tecnológicas e mercadológicas, apoio legal e institucional, promoção de cursos, eventos técnicos e comerciais e feiras: Sindicato dos Trabalhadores, Federação da Indústria da Paraíba (Fiep), Associação dos MPEs de Campina Grande, Associação da Indústria do Vestuário de Campina Grande e o Sindicato das Empresas de Confecções da Paraíba. Além disso, a cidade conta com o Centro Nacional de Pesquisa do Algodão, da Empresa Brasileira de Pesquisas Agronômicas (Embrapa). 


\section{CONSIDERAÇÕES FINAIS}

Ainda que incipientes, e talvez por isso não objeto de muitos estudos mais robustos no que diz respeito aos resultados alcançados, as políticas de promoção dos APLs evidenciam ao menos uma coisa: elas não são simples, por mais simplória que, por vezes, pareçam as atividades em que se concretizam. De fato, a experiência acima relatada do APL Pingo D’Água demonstra que o fomento à produção nem sempre exige grandes e vultosos planos; pode ser que um investimento pequeno em valores absolutos, somado a ações de assistência técnica eficazes, que partam de uma identificação adequada dos problemas verificados e das demandas dos agentes, seja o bastante para provocar modificações significativas na estrutura produtiva local e beneficiar um número grande de pessoas que se vinculem a um determinada atividade.

Todavia, como qualquer atividade produtiva reúne uma multiplicidade de aspectos, que são dificilmente abrangidos de todo nas competências jurídicas das entidades administrativas de fomento, é inevitável que a ação estatal se dê sempre mediante a conjugação de instituições múltiplas, cada qual com sua missão específica. Daí a preocupação com a governança nos programas de incentivo aos APLs. Sem mecanismos de coordenação, não só os resultados da ação pública se dissipam como a cooperação entre os agentes privados se torna dificultosa.

Porém, de nada vale uma arquitetura institucional sofisticada e um corpo burocrático qualificado a concretizá-la, se o diagnóstico da ação pública não se der em tempo apropriado. No intercurso da elaboração do presente trabalho, inúmeros foram os estudos oriundos de entidades governamentais consultados que mais se afeiçoavam a material de divulgação, não podendo ser aproveitados em razão da inexistência de um exame minimamente robusto das características econômicas da região em que os APLs se situam ou dos efeitos que as ações de fomento tiveram seriam destindas a intentar.

A impressão que se tem é que a simples ocorrência de um fenômeno aglomerativo, ainda que de pouca significância, pode servir de pretexto para que a entidade governamental local enuncie ali a existência de um APL e demande a atuação de outras instituições de fomento. Por isso é que se tem denunciado os riscos do uso do termo APL 
como simples modismo ${ }^{255}$ ou como um instrumento não de política industrial, mas de simples programa de emprego e renda que seria incapazes até mesmo de contribuir para transformações acentuadas no quadro de desigualdades regionais do país ${ }^{256}$.

Existe, pois, de fato, um dilema de política pública: canalizar investimento público somente para as aglomerações já dotadas de algum grau de maturidade ou explorar potencialidades latentes em localidades que não desenvolveram uma determinada atividade por pura falta de apoio? A resposta a essa questão não cabe nesta pesquisa, aliás, talvez não não caiba em pesquisa alguma, porque é uma questão puramente política. Contudo, não se pode negligenciar o fato de, se os resultados da ação pública - como tudo no campo da vida prática - são marcados por incertezas (de modo que privilegiar um arrranjo mais maduro em detrimento de outro incipiente não seja garantia de que o investimento redunde em benefícios para a sociedade), o formulador de políticas públicas, por sua vez, tem a certeza de que qualquer projeto de desenvolvimento nacional tem que lidar com a superação das desigualdades regionais.

Apesar de não haver, em princípio, uma justificativa para se priorizar o apoio aos Arranjos Produtivos Locais vis a vis outras estratégias de políticas industriais, a abordagem de políticas em torno da ideia de APLs pode se mostrar útil para lidar concomitantemente com o desenvolvimento produtivo e os desafios da igualação das condições de vida. Mas ela se mostra ainda incipiente, deixando em suspenso a possibilidade de se colocar em execução um plano de desenvolvimento nacional que consiga articular as três esferas federativas tendo em vista a exploração de todas potencialidades de nosso território. Obviamente que isso é por demais complexo e trabalhoso, mas não foi verdadeiramente intentado com afinco até hoje. Vejamos por mais quanto tempo.

\footnotetext{
${ }^{255}$ LEMOS, Cristina, ALBAGLI, Sarita e SZAPIRO, Marina: Políticas de promoção do arranjos produtivos locais no Brasil: evolução recente e desafios atuais. moda dos APLs in LASTRES, Helena \& CASSIOLATO, José E. Estratégias para o Desenvolvimento: um enfoque sobre Arranjos Produtivos Locais do Norte, Nordeste e Centro-Oeste Brasileiros. Rio de Janeiro, E-papers, 2006.

${ }^{256}$.SCHMIDT FILHO, Ricardo e DE PAULA, Nilson M. Paula Incentivos à Formação de APLs no Brasil: a atual distribuição espacial das iniciativas e evidências de uma falsa política industrial. Disponível em erevista.unioeste.br/index.php/gepec/article/download/1812/1463
} 


\section{BIBLIOGRAFIA}

ABRAMOVAY, Ricardo \&. JUNQUEIRA, Rodrigo Gravina P. "A sustentabilidade das finanças solidárias”. Revista de Administração, São Paulo, v. 40, n. 1, 2005, p. 19-33.

ALVES, Tiago R. Estudo de caso: O papel do cooperativismo no desenvolvimento regional sustentável e no surgimento de um Arranjo Produtivo Local (APL) do setor leiteiro. Disponível em http://www.biblioteca.sebrae.com.br/bds/ BDS.nsf/ 4CD7E56B66FE76C1032571E80044B79B/\$File/NT0003222A.pdf. Acesso em 20/12/2009.

AMARAL FILHO, Jair do. "A Endogeneização no Desenvolvimento Econômico Regional e Local”. Planejamento e Políticas Públicas. Brasíia:IPEA, v. 23, p. 261-286, 2001.

AMARAL FILHO, Jair do. "É negócio ser pequeno, mas em grupo". Desenvolvimento em Debate 3: Painéis do Desenvolvimento Brasileiro. Rio de Janeiro, BNDES, dez./2002.

BANCO CENTRAL DO BRASIL. Nota sobre Política Monetária e Operações de Crédito do Sistema Financeiro. Brasília: Dezembro de 2009.

BECKER, Alfredo Augusto. Teoria Geral do Direito Tributário. São Paulo, Lejus, 1998, $3^{\mathrm{a}}$ ed., p. 587-588.

ATABILA, Geraldo. "Subvenção municipal a empresas, como incentivo à industrialização". Justitia, v.72, p. 153 apud BANDEIRA DE MELLO, Celso Antônio \& ATABLIBA, Geraldo. "Subvenções: Natureza jurídica". Revista de Direito Público, vol. 20, abr./jun. 1972, p. 88.

Banco Central do Brasil. Nota sobre Política Monetária e Operações de Crédito do Sistema Financeiro, dez. 2009.

BANDEIRA, Pedro S. "As Mesorregiões no Contexto da Nova Política Federal de Desenvolvimento Regional: Considerações Sobre Aspectos Institucionais e Organizacionais". Disponível em http://www.integracao.gov.br/ publicacoes/ desenvolvimentoregional/publicacao/Cedeplar/

BERCOVICI, Gilberto. Constituição Econômica e Desenvolvimento: Uma Leitura a partir da Constituição de 1988. São Paulo: Malheiros, 2005.

Max Limonad, 2003

Desigualdades Regionais, Estado e Constituição. São Paulo:

“ Os Princípios Estruturantes e o Papel do Estado", em

CARDOSO JR, José Celso. (Org.). A Constituição Brasileira de 1988 Revisitada: Recuperação Histórica e Desafios Atuais das Políticas Públicas nas Áreas Econômica e Social. Brasília: Instituto de Pesquisa Econômica Aplicada, 2009, v. 1, p. 255-291

BNDES. Arranjos Produtivos Locais e Desenvolvimento, 2004. 
BRANDÃO, Carlos. Território \& Desenvolvimento: as múltiplas escalas entre o local e o global. Campinas, Editora Unicamp, 2007

BRABET, Catherine \& PALLET, Domenique. "Os selos oficiais de qualidade dos alimentos na França e na Europa" em LAGES, Vinicius \& Lagares, Lea \& BRAGA, Cristiano Lima (org). Valorização de produtos com diferencial de qualidade e identidade: indicações geográficas e certificações para competitividade nos negócios. Brasília: SEBRAE, 2005.

BRASIL, Diretrizes de Política Industrial, Tecnológica e de Comércio Exterior, 2003.

BRASIL, Termo de Referência para Política Nacional de Apoio ao Desenvolvimento de Arranjos Produtivos Locais, 2004.

BROGINI, Gilvan Daminiani. OMC e Indústria Nacional: as Salvaguardas para o Desenvolvimento. Aduaneiras: São Paulo, 2004.

BUCCI, Maria Paula Dallari. Direito Administrativo e Políticas Públicas. São Paulo: Saraiva, 2002.

CÂMARA, Jacintho Arruda. "O regime tarifário como instrumento de políticas públicas". Revista de Direito Público da Economia - RDPE, Belo Horizonte: Fórum, ano 3, n. 12, out./dez. 2005, p. 107.

CAMPANÁRIO, Milton de Abreu \& SILVA, Marcello Muniz da. "Fundamentos de uma Nova Política Industrial" em FLEURY, Maria Tereza Leme \& FLEURY, Afonso (org.). Política Industrial 1, São Paulo, PubliFolha/FEA-USP, 2004.

CAMPOS, Hélio S. Ourem . "O Finor e o desenvolvimento do Nordeste - processos de distribuição e de concentração de renda”. Prisma Jurídico, v. 7, p. 1-22, 2008.

CANO, Wilson. Desequilíbrios regionais e concentração industrial no Brasil: 1930-1970. $3^{\text {a }}$. ed. São Paulo: UNESP, 2007.

CARARRO, Antônio F. Apresentação "Crédito e instrumentos financeiros para APLs" no Seminário "Arranjos produtivos locais como instrumento de desenvolvimento". Revista do BNDES. Rio de Janeiro: 2004. Disponível em www.bndes.gov.br/SiteBNDES/export/sites/ default/bndes_pt/.../ap19.pdf.

CARRAZA, Roque A. Curso de Direito Constitucional Tributário. São Paulo: Malheiros, $20^{\mathrm{a}}$ ed. 2004.

CARVALHO, Daniela Gomes de. "Licitações sustentáveis, alimentação escolar e desenvolvimento regional: uma discussão sobre o poder de compra governamental a favor da sustentabilidade”. IPEA, Planejamento e Políticas Públicas, n. ${ }^{\circ}$ 32, jan./jun. 2009.

CASSIOLATO, José. E. Relatório do Grupo de Trabalho para Arranjos Produtivos Locais. Brasília: MDIC, 2004.

CASSIOLATO, José. E. \& LASTRES, Helena. M. "O foco em arranjos produtivos locais de micro e pequenas empresas" em LASTRES, Helena M. M.; CASSIOLATO, José E.; 
MACIEL, M.L. Pequena Empresa: Cooperação e desenvolvimento local. Rio de Janeiro. Relume Dumará, 2003.

CASSIOLATO, J. E.; SZAPIRO, M. "Uma caracterização de arranjos produtivos locais de micro e pequenas empresas" em LASTRES, H.M.M.; CASSIOLATO, J.E.; MACIEL, M.L. Pequena Empresa: Cooperação e desenvolvimento local. Rio de Janeiro. Relume Dumará, 2003.

CAVALCANTE, Luiz R. M. T. "Produção Teórica em Economia Regional:Uma Proposta de Sistematização". Revista Brasileira de Estudos Regionais e Urbanos, v. 02, p. 9-32, 2008.

CHANG, Ha-Joon. The Political Economy of Industrial Policy. New York: St Martin's Press, 1994.

Chutando a escada - A estratégia do desenvolvimento em perspectiva histórica. São Paulo: Unesp, 2004.

COMPARATO, FÁBIO K. O Indispensável Direito Econômico. Revista dos Tribunais, vol. 353, 1965, pp. 453-472.

CONCEIÇÃO, Júnia Cristina P. R. da. "Contribuição dos novos instrumentos de comercialização (contratos de opção e PEP) para estabilização de preço e renda agrícolas". .Brasília, Ipea, Texto para Discussão 927, 2002.

COUTINHO, Luciano. "Coréia do Sul e Brasil: paralelos, sucessos e desastres." In FIORI, José L. Estados e Moedas no Desenvolvimento das Nações. Petrópolis: Vozes, 1999.

COUTINHO, Luciano. "Marcos e Desafios de uma Política Industrial Contemporânea". em CASTRO, Ana Célia. (Org.). Desenvolvimento em Debate. Rio de Janeiro: MUADBNDES, 2002.

COSTA, Achyles B. da \& COSTA, Beatriz M. da. Cooperação e Capital Social em Arranjos Produtivos Locais. Disponível em http://www.anpec.org.br/encontro2005/ artigos/A05A113.pdf.

DELGADO, Guilherme C. "Estoques Governamentais de Alimentos e Preços Públicos". Brasília: Ipea, dez 1995. Texto para Discussão n. 395.

DINIZ Clélio C., SANTOS, Fabiana \& CROCCO, Marco. "Conhecimento, Inovação e Desenvolvimento Regional". Relatório do Projeto Diretrizes para Formulação de Políticas de Desenvolvimento Regional e de Ordenação do Território Brasileiro. Disponível em: http://www.integracao.gov.br/publicacoes/desenvolvimentoregional/publicação.

DI PIETRO, Maria Sylvia Z. “A Gestão Jurídica do Patrimônio Imobiliário do Poder Público". Cadernos da FUNDAP, São Paulo, ano 9, n. 17, dez. 1989

DI PIETRO, Maria Sylvia Z. Parcerias na Administração Pública. São Paulo: Atlas, 2008, $6^{\mathrm{a}}$ ed, p. 230-231.

ERBER, Fabio S. "Eficiência coletiva em arranjos produtivos locais industriais: comentando o conceito". Nova Economia. Belo Horizonte: UFMG, n. ${ }^{\circ}$ 18, jan./abr. 2008 
ERBER, Fabio S. \& CASSIOLATO, José E. "Política Industrial - teoria e prática no Brasil e na OCDE”. Revista de Economia Política, vol 17, n. ${ }^{\circ} 2$ (66), abril-junho, 1997.

FERREIRA, Glenda. Políticas de Desenvolvimento Regional e Guerra Fiscal. Doutorado em Economia. Unicamp, 2005

FERREIRA, Pedro Cavalcanti Gomes; PESSÔA, S. A.; SCHYMURA, Luiz Guilherme ; CANEDO, Maurício . "O Brasil Precisa de uma Política Industrial? De que tipo?". Rio de Janeiro: FGV, Ensaios Econômicos, 644, 2007.

FLEURY, Afonso \& FLEURY. Maria Tereza Leme. "Por uma Política industrial desenhada a partir do tecido industrial" em FLEURY, Maria Tereza Leme \& FLEURY, Afonso (org.). Política Industrial 1, São Paulo, PubliFolha/FEA-USP, 2004

GRAU, Eros R. A Ordem Econômica na Constituição de 1988: Interpretação e Crítica. São Paulo: Revista dos Tribunais, 2008, $13^{\mathrm{a}} \mathrm{ed}$.

GURGEL, Viviane A. "Aspectos Jurídicos da Indicação Geográfica” em LAGES, Vinicius \& Lagares, Lea \& BRAGA, Cristiano Lima (org) Valorização de Produtos com Diferencial de Qualidade e Identidade: Indicações Geográficas e Certificações para Competitividade nos Negócios. Brasília: Sebrae, 2005.

HADDAD Paulo R. Texto de Referência da Palestra Sobre Cultura Local e Associativismo. BNDES, 2004.

HASENCLEVER, L.\& ISSIMOS, I. "A Evolução das Configurações Produtivas Locais no Brasil: uma revisão da literatura”. Revista de Estudos Econômicos, v. 36, p. 407-433, 2006.

IACONO, Antonio \& NAGANO,M.S.. "Uma Análise e Reflexão sobre os Principais Instrumentos para o Desenvolvimento Sustentável dos Arranjos Produtivos Locais no Brasil". Revista Gestão Industrial, v. 3, p. 37-51, 2007

IGLIORI, Danilo Camargo. Economia dos Clusters Industriais e Desenvolvimento. São Paulo: Iglu Editora, 2001.

JACOB, Carlos Augusto Antonelli; BRANDÃO, Júlia B. e GODOY, Melissa Giacometti. Projeto Pingo D'Água - Quixeramobim Ceará. São Paulo: FGV, 2006. Disponível em http://www.eaesp.fgvsp.br/ subportais/ interna/ Conexao_Local/ 08_CL_2006_PingoDagua.pdf

JUSTEN FILHO, Marçal. Comentários à Lei de Licitações e Contratos Administrativos. São Paulo: Dialética, 13ªed., 2009

JUSTEN FILHO, Marçal. O Estatuto da Microempresa e as Licitações Públicas. São Paulo: Dialética, 2007.

KUPFER, David; FERRAZ, João C. \& DE PAULA, Germano. "Política Industrial" em KUPFER, David \& HASENCLEVER, Lia.. (Org.). Economia Industrial: Fundamentos Teóricos e Práticas no Brasil. Rio de Janeiro: Campus, 2002.

LAFER, Betty Mindlin. Planejamento no Brasil. 2a ed. São Paulo: Perspectiva, 1973. 
LASTRES, Helena \& CASSIOLATO (org), José E. Estratégias para o Desenvolvimento: um enfoque sobre Arranjos Produtivos Locais do Norte, Nordeste e Centro-Oeste Brasileiros. Rio de Janeiro, E-papers, 2006.

LAPLANE, Mariano, CASSSIOLATO, José E. \& LASTRES, Helena. "Projeto Política Brasileira de Ciência,Tecnologia e Inovação: A Lei de Inovação e o Sistema Nacional de C \& T \& I". Centro de Gestão e Estudos Estratégicos. Rio de Janeiro, 2007

LEMOS, C., ALBAGLI, S. \& SZAPIRO, M. "Promoção de arranjos produtivos locais: iniciativas em nível federal". RedeSist. Nota Técnica RedeSist, Rio de Janeiro, 2004. Disponível em www.sinal.redesist.ie.ufrj.br.

LEMOS, Cristina, ALBAGLI, Sarita \& SZAPIRA, Marina. "Políticas de promoção de arranjos produtivos locais no Brasil: evolução recente e desafios atuais" em LASTRES, Helena \& CASSIOLATO (org), José E. Estratégias para o Desenvolvimento: um enfoque sobre Arranjos Produtivos Locais do Norte, Nordeste e Centro-Oeste Brasileiros. Rio de Janeiro, E-papers, 2006, pp 249-266.

LEMOS, Mauro Borges. "Regionalização: análise da experiência brasileira recente". Relatório do Projeto Diretrizes para Formulação de Políticas de Desenvolvimento Regional e de Ordenação do Território Brasileiro. Disponível em: http://www.integracao.gov.br/publicacoes/desenvolvimentoregional/publicação.

LIMA, G. B., NEVES, M.F \& OLIVEIRA, L. Consórcio de Exportação como Alternativa às Pequenas e Médias Empresas: Um caso na Cadeia Têxtil - Anais do XL Congresso Brasileiro de Economia e Sociologia Rural - SOBER, "Equidade e Eficiência na Agricultura Brasileira", Universidade de Passo Fundo (UPF), Passo Fundo - Rio Grande do Sul, 28 a 31 de julho de 2002.

LOPES, Simone S., LAGOA JUNIOR José Carlos dos S. CARDOSO, Marcelo P. \& Piccinini, Maurício S. "Fundos de Garantia e Acesso ao Crédito das Micro, Pequenas e Médias Empresas. a Experiência do FGCP: Sucesso Ou Fracasso?"BNDES Setorial, Rio de Janeiro, n. 26, p. 3-24, set. 2007.

MACEDO JR. RONALDO P. Contratos Relacionais e Defesa do Consumidor. São Paulo: RT, 2006, $2^{\circ}$ ed..

MACHADO, Alexandre F. "As Indicações Geográficas no Brasil e no Mundo - panorama atual". Em BALIEIRO LIMA, Luis F. (org.). Propriedade Intelectual no Direito Empresarial. São Paulo: Quartier Latin, 2009, pp 155-198.

MARQUES CAVALCANTE, Anderson T. Financiamento e Desenvolvimento Local: um estudo sobre Arranjos Produtivos Locais. Doutorado em Economia. UFMG, 2006.

MARQUES NETO, Floriano de A. "Limites à abrangência e à intensidade da regulação estatal”. Revista de Direito Público da Economia, Belo Horizonte, Fórum, n. 1, jan.-mar. 2003

MARQUES NETO, Floriano P. Bens Públicos: Função social e exploração econômica. Belo Horizonte: Fórum, 2009. 
MARSHALL, Alfred. Princípios de economia: tratado introdutório. São Paulo: Abril Cultural, 1982.

MELlO, Célia Cunha. O Fomento da Administração Pública. Belo Horizonte: Del Rey, 2003.

MOREIRA NETO, Diogo de Figueiredo. Curso de Direito Administrativo. Rio de Janeiro: Forense, $14^{\mathrm{a}}$ ed.

MOREIRA, Sévulo V; Tomich, Frederico \& Rodrigues, Maria da Gloria. "Proex e BNDES-Exim: construindo o futuro". Brasília, IPEA. 2006. Texto para Discussão.

MOUTINHO, Lúcia M \& CAVALCANTI FILHO, Paulo. F. "Proposição de Políticas para Arranjos e Sistemas Produtivos e Inovativos Locais ASPILs: O Arranjo Produtivo de Confecções de Campina Grande/PB - Relatório Final". Disponível em www.redesist.ie.ufrj.br/.../Pane1\%2007\%20-\%20Paulo\%20Cavalcanti\%20and\%20Lucia\%20Moutinho.pdf

MOUTINHO, Lúcia M. G. \& CAVALCNTI FILHO, Paulo F. "Inovatividade e cooperação no arranjo produtivo local de confecções em Campina Grande-PB" em LASTRES, Helena \& CASSIOLATO, José E. Estratégias para o Desenvolvimento: um enfoque sobre Arranjos Produtivos Locais do Norte, Nordeste e Centro-Oeste Brasileiros. Rio de Janeiro, E-papers, 2006, pp. 175-192.

MOUTINHO, Lúcia M. G \& CAMPOS, Renato. "A Co-Evolução de Empresas e Instituições em Arranjos Produtivos Locais": Políticas Públicas e Sustentabilidade. Revista Econômica do Nordeste, Fortaleza, v. 38, nº 2, abr-jun. 2007.

NARETTO, Nilson, BOTELHO, Marisa dos R. \& MENDONÇA, Maurício. “A Trajetória das Políticas Públicas Para Pequenas e Médias Empresas No Brasil: do Apoio Individual ao Apoio a Empresas Articuladas em Arranjos Produtivos Locais”. IPEA. Planejamento e Polícias Públicas, n. ${ }^{\circ} 27$ |jun./dez. 2004.

NASSER, Rabih Ali. A OMC e os Países em Desenvolvimento. São Paulo: Aduaneiras, 2003.

NASSIF, André. "Uma proposta de política industrial para o Brasil: objetivos, critérios e setores prioritários". Revista do BNDES, Rio de Janeiro, v. 10, n. ${ }^{\circ}$ 20, 2003.

"Uma contribuição ao debate sobre a nova política industrial brasileira". Rio de Janeiro: BNDES, 2003, Texto para discussão 101, setembro 2003.

"Política industrial após a liberalização do comércio exterior: o debate teórico contemporâneo". Revista do BNDES, Rio de Janeiro, v. 9, n. 17, , 2002.

NORONHA, E. e TURCHI, L. "Política Industrial e Ambiente Institucional na Análise de Arranjos Produtivos Locais". IPEA. Texto para Discussão n. ${ }^{\circ}$ 1076. Brasília, 2005. www.ipea.gov.br

NUSDEO, Fábio. "Banco de Desenvolvimento", verbete da Enciclopédia Saraiva do Direito. São Paulo: Saraiva, v. 10, pp. 247-249. 
OLIVEIRA SOUZA, Jorge Henrique de. Tributação e Meio ambiente. Belo Horizonte: Del Rey, 2009.

PACHECO MOREIRA, Claudia Cristina. "A extinção da SUDAM e da SUDENE". Revista de Informação Legislativa. Disponível em http://www.buscalegis.ufsc.br/revistas/index.php/buscalegis/article/viewFile/26847/26410

PEREIRA JR., Jessé Torres \& DOTTI, Marines Restelatto. Políticas Públicas nas Licitações e Contratações Administrativas. Belo Hozinte: Fórum, 2009.

PINTO JR,Cyro C. G., FERNANDES, Ricardo L. e CAIRO, Silvio Antonio F. "Análise do Arranjo Produtivo Cerâmico de Revestimento da Região Sul de Santa Catarina: Dinâmicas Produtiva, Inovativa, Comercial e Institucional" Disponível em http://www.apec.unesc.net/II\%20EEC/Industrial/Artigo1.pdf.

PLONSKI, Guilherme A. "Mantras da Inovação", em: FLEURY, Maria Tereza \& CORREA FLEURY, Afonso Carlos. (Org.). Política Industrial 2. São Paulo: Publicafolha, 2004.

POZAS, Luis Jordana. "Ensayo de una teoria del fomento en el Derecho Administrativo". Revista de Estudios Políticos, n. 48, p. 46, 1949.

PUGA, Fernando P. "Alternativas de apoio a MPMEs localizadas em Arranjos Produtivos Locais”. Rio de Janeiro: BNDES, 2003. Textos Para Discussão 99, pp. 25-26.

RAUPP, Fabiano Maury \& BEUREN, Ilse Maria. "Programas oferecidos pelas incubadoras brasileiras às empresas incubadas". Revista de Administração e Inovação, São Paulo, v. 6, n. 1, p. 83-107, 2009.

RIBEIRO, Paulo Antônio N. "Agências de fomento - ambientes institucional, legal e operacional”. Revista da Desenbahia, Salvador, vol. 1, set. 2004.

ROCHA, Silvio da. Terceiro Setor. Malheiros, 2003

RODRIK, Dani. "Industrial Policy for the Twenty-first Century". Harvard University, 2004.

SALVIANO JUNIOR, Cleofas. Bancos Estaduais: dos Problemas Crônicos ao Proes. Brasília, Banco Central do Brasil, 2004.

SCHAPIRO, Mário G. Política Industrial e Disciplina da Concorrência pós-Reformas de Mercado: uma avaliação institucional do ambiente de inovação tecnológica. Mestrado em Direito Econômico, USP, 2005.

Novos parâmetros para a intervenção do estado na economia: persistência e dinâmica na atuação do BNDES em uma economia baseada no conhecimento. Doutorado em Direito, USP, 2009

SCHMIDT FILHO, Ricardo e DE PAULA, Nilson M. Paula . "Incentivos à Formação de APLs no Brasil: a atual distribuição espacial das iniciativas e evidências de uma falsa política industrial". Disponível em e-revista.unioeste.br/index.php/gepec/article/download/1812/1463. 
SCHMITZ, H. "Collective efficiency and increasing returns". IDS Working Paper $n^{o} .50$. Institute of Development Studies, University of Sussex, Brighton, 1997

SCHMITZ, H. "Clustering and industrialization: Introduction". World Development 27, 1999.

SEBRAE, Metodologia para APLs, 2004.

SILVA ALVES, Maria Abadia. Guerra Fiscal e Finanças Federativas no Brasil: O Caso do Setor Automotivo. Mestrado em Economia, Unicamp, 2001.

SILVA, Cássio Garcia. A Política de Compras de Entidades Públicas como Instrumento de Capacitação Tecnológica: o Caso da Petrobrás. Mestrado em Política Científica e Tecnológica. Unicamp, 2005.

SOUTO, Marcos Juruena. V. "Estímulos positivos". In: MARTINS CARDOZO, José Eduardo; LOPES QUEIROZ, João Eduardo; BATISTA DOS SANTOS Márcia W. (Org.). Curso de Direito Administrativo Econômico. São Paulo: Malheiros, 2006, v. II.

STRACHMAN, Eduardo. Política Industrial e Instituições. Tese de Doutorado. Unicamp, 2000.

SUNDFELD, Carlos Ari. Direito Administrativo Ordenador, São Paulo: Malheiros, 2003.

SUZIGAN, Wilson. "Aglomerações Industriais: Avaliação e Sugestões de Políticas". Ministério do Desenvolvimento, Indústria e Comércio Exterior; Instituto Evaldo Lodi. (Org.). Futuro de Indústria: Oportunidades e Desafios - a Reflexão da Universidade. Brasília: Ministério de Desenvolvimento, Indústria e Comércio Exterior, 2001.

SUZIGAN, Wilson.; FURTADO, João; GARCIA, R. O; SAMPAIO, S. E. K. . "Sistemas Locais de Produção: Mapeamento, Tipologia e Sugestões de Políticas". Revista de Economia Política, v. 24, n. 4, p. 543-562, 2004.

SUZIGAN, Wilson.; FURTADO, J; GARCIA, R.. "Estruturas de Governança em Arranjos ou Sistemas Locais de Produção". Gestão e Produção (UFSCar), v. 14, p. 425-439, 2007.

SUZIGAN, Wilson. \& FURTADO, João. "Política Industrial e Desenvolvimento". Revista de Economia Política, São Paulo, v. 26, p. 2006

SUZIGAN, Wilson. "Política Industrial e Desenvolvimento Regional". Revista Observatório da Indústria, Paraná, v. 9, p. 34-35, 2005.

SUZIGAN, Wilson. (coord). Identificação, Mapeamento e Caracterização Estrutural de Arranjos Produtivos Locais no Brasil. IPEA, 2006.

TORRES, Silvia Faber. O Princípio da Subsidiariedade no Direito Público Contemporâneo. Rio de Janeiro, Renovar, 2001

TORRES FILHO, Ernani T. "Crédito Direcionado e Direcionamento do Crédito: Situação Atual e Perspectivas". Revista do BNDES, Rio de Janeiro, v. 13, n. 25, p. 35-50, jun. 2006. 
VARGAS, M. A.; CASSIOLATO, José E. ; BRITTO, J. P. . "Instrumentos Financeiros para Arranjos e Sistemas de MPME" apud MOTTA DE LIMA, Adelaide, CASTRO LIMA, Carmen Lucia \& RODRIGUES MATTA, João P. "Finanças de proximidade: um modelo de financiamento para arranjos produtivos locais". Disponível em www.neapl.sedetec.se.gov.br/modules/wfdownloads/visit.php?cid=1...3. 